"Modern Civic Art; or, the City Made Beautiful":

Aesthetic Progressivism and the Allied Arts in Canada, 1889-1939

By Julie Nash

A Thesis Submitted to the Faculty of Graduate and Postdoctoral Affairs In partial fulfillment of the requirements for the degree of Master of Arts

In Art History: Art and Its Institutions

School For Studies in Art and Culture

Carleton University

Ottawa, Ontario

(C) 2011

Julie Nash 
Library and Archives

Canada

Published Heritage

Branch

395 Wellington Street Ottawa ON K1A ON4 Canada
Bibliotheque et

Archives Canada

Direction du

Patrimoine de l'édition

395 , rue Wellington

Ottawa ON K1A ON4

Canada
Your file Votre référence

ISBN: 978-0-494-83094-9

Our file Notre réference

ISBN: 978-0-494-83094-9
NOTICE:

The author has granted a nonexclusive license allowing Library and Archives Canada to reproduce, publish, archive, preserve, conserve, communicate to the public by telecommunication or on the Internet, loan, distribute and sell theses worldwide, for commercial or noncommercial purposes, in microform, paper, electronic and/or any other formats.

The author retains copyright ownership and moral rights in this thesis. Neither the thesis nor substantial extracts from it may be printed or otherwise reproduced without the author's permission.
AVIS:

L'auteur a accordé une licence non exclusive permettant à la Bibliothèque et Archives Canada de reproduire, publier, archiver, sauvegarder, conserver, transmettre au public par télécommunication ou par l'Internet, prêter, distribuer et vendre des thèses partout dans le monde, à des fins commerciales ou autres, sur support microforme, papier, électronique et/ou autres formats.

L'auteur conserve la propriété du droit d'auteur et des droits moraux qui protège cette thèse. $\mathrm{Ni}$ la thèse ni des extraits substantiels de celle-ci ne doivent être imprimés ou autrement reproduits sans son autorisation.
In compliance with the Canadian Privacy Act some supporting forms may have been removed from this thesis.

While these forms may be included in the document page count, their removal does not represent any loss of content from the thesis.
Conformément à la loi canadienne sur la protection de la vie privée, quelques formulaires secondaires ont été enlevés de cette thèse.

Bien que ces formulaires aient inclus dans la pagination, il n'y aura aucun contenu manquant.

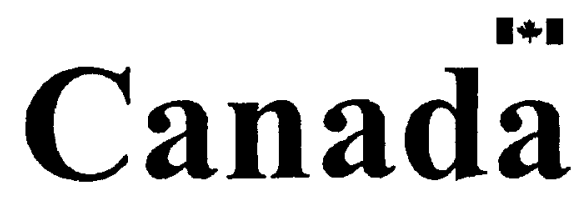


$\underline{\text { Abstract }}$

\section{"Modern Civic Art; or, the City Made Beautiful": Aesthetic Progressivism and the Allied Arts in Canada, 1889-1939}

This thesis analyzes Canadian civic art, which amalgamates fine art beautification and utilitarian infrastructure, alongside a series of progressive North American city planning approaches, including the City Beautiful, Social Gospel and Progressivism, and City Scientific. These collectively amount to comprehensive city planning, which inspired a generation of progressive Canadian aesthetes who united their professions under the allied arts, a fine arts network. These were publicized through George Reid's murals in the Toronto Municipal Buildings (1897-1899), John Lyle's formal garden at the Parkwood Estate in Oshawa (1935-1936), and the Biennial Exhibitions of Architecture and the Allied Arts (1927-1939). Canadian civic art became the ideal paradigm of collaborative city planning, examined here through beautification and improvement projects in Hamilton, Ontario from 1920 to 1939. Completed civic art projects include Gage Park, McMaster University and Royal Botanical Gardens, the northwestern entrance and the new High-Level Bridge, and the Queen Elizabeth Way. 


\section{Acknowledgements}

Historical literature written by period artists, architects, engineers and other Canadian professionals form a significant component of this thesis. As a result, I am very grateful to the staff at both Mills Memorial and Thode Libraries at McMaster University for their assistance in sourcing these essays. Furthermore, a great deal of important archival information was gathered at the Special Collections Department of the Hamilton Public Library, whose staff I thank for their expertise in locating historical scrapbooks, newspaper articles, city planning reports and unpublished essays.

This thesis would not have been possible without the continuous support, advice and encouragement given to me by my supervisor, Dr. Brian Foss. With his help this thesis has transformed from a nebulous concept into a tangible research project. I will always be grateful for his faith and enthusiasm for this project. Many thanks also to my committee, Dr. Joan Coutu of the University of Waterloo, and Drs. Peter Coffman and Angela Carr of Carleton University.

I would also like to thank Dr. Mary Anderson for her mentoring in the early stages of this process, as well as for her assistance in locating relevant sources and images throughout my research. Many thanks also to Linda, Stephen and Melanie Nash for lasting encouragement and support throughout this process, and to Karol Wojdaszka for accompanying me to see many civic art projects as I was researching. This thesis is dedicated to John Richard Powell, a continuous font of love and inspiration. 
Table of Contents

Abstract

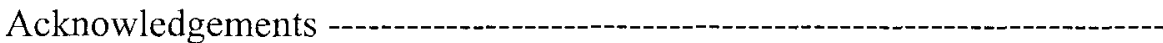

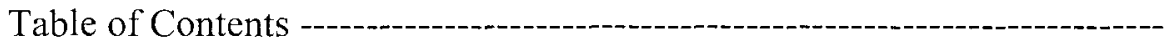

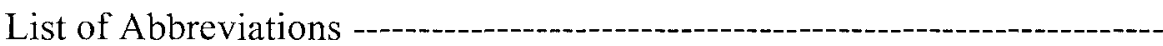

List of Figures

\section{Introduction}

Statement of the Research Problem -- 1

Chapter Breakdown --.----- 3

Literature Review --..- 5

Methodology ---

Chapter One -

The City Planning Movement and the Awakening of Canadian Civic Art Introduction --

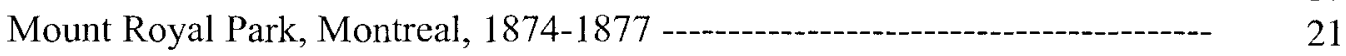

The City Beautiful --on

The Social Gospel and Progressivism --o-_- 32

The Toronto Guild of Civic Art -- 36

The City Scientific: Efficacious Planning -- 39

Chapter Two -

How Reform Can Come to the Arts: The Canadian Allied Arts

Introduction ---

George A. Reid ---

The Murals in the Toronto Municipal Buildings, 1897-1899 --o-a--.----- 58

The Biennial Exhibitions of Architecture and the Allied Arts, 1927-1939 62

John Lyle's Renovations to 'Parkwood,' The McLaughlin Family Estate 67

The Allied Arts in Circulation ---o-

\section{Chapter Three - Regional Beautification: Civic Art in Hamilton}

Introduction ---

Noulan Cauchon and The Legacy of Civic Improvement in Hamilton ----- $\quad 80$

Early Improvements: The Board of Parks Management and Beautification $\quad 87$

Edification and Dissemination: Hamilton's Beautification Ethos ---------- 91

Circulation: Enhanced Roadways and Tourism --an 98

Hamilton, The City Beautiful -.-.- 103

Conclusion - Beauty is Not a Dirty Word -

Figures --

Bibliography -.-.-. 174 
$\underline{\text { Abbreviations }}$

\section{Publications}

CAB Canadian Architect and Builder

JRAIC Journal, Royal Architectural Institute of Canada

\section{Professional Associations}

BPM Hamilton Board of Parks Management

CSLA Canadian Society of Landscape Architects

OAA Ontario Association of Architects

RAIC Royal Architectural Institute of Canada

TGCA Toronto Guild of Civic Art

TPB Hamilton Town Planning Board

TPIC Town Planning Institute of Canada

Art Galleries, Institutions and Infrastructure Projects

AGT Art Gallery of Toronto (later renamed the Art Gallery of Ontario)

RBG Royal Botanical Gardens (Hamilton, Ontario)

QEW Queen Elizabeth Way 


\section{List of Figures}

\section{Chapter One -}

\section{The City Planning Movement and the Awakening of Canadian Civic Art}

Fig. 1: Frederick Law Olmsted, Sr., Plan for Mount Royal (1881).

Fig. 2: Charles Garnier, facade of Paris Opéra House (1858-1872).

Photo Credit: Gilbert A. Stelter "Rethinking the Significance of the City Beautiful Idea," Urban Planning in a Changing World: The Twentieth Century Experience, ed. Robert Freestone (London: E \& FN Spon, 2000).

Fig. 3: City Beautiful inspired neo-classical buildings and sculpture at the Chicago World's Exposition (1893). Photo Credit: Gilbert A. Stelter "Rethinking the Significance of the City Beautiful Idea," Urban Planning in a Changing World: The Twentieth Century Experience, ed. Robert Freestone (London: E \& FN Spon, 2000).

Fig. 4: Lorado Taft, sculptural adornment on the Horticultural Building at the 1893 Chicago World's Exposition, Sleep of Flowers and Awakening of Flowers. Photo Credit: Timothy Garvey, Public Sculptor, Lorado Taft and the Beautification of Chicago (Urbana: University of Illinois Press, 1988).

Fig. 5: Lorado Taft, Fountain of the Great Lakes (1913), pictured here in its original location outside the Art Institute of Chicago. Photo Credit: Timothy Garvey, Public Sculptor, Lorado Taft and the Beautification of Chicago (Urbana: University of Illinois Press, 1988).

Fig. 6: Edward Bennett, City Beautiful design for Ottawa's civic centre including the existing Parliament Buildings at the top left (1915).

Fig. 7: C.A. Dawson, diagrams illustrating the theory of the city as an organism (c.1926).

Fig. 8: Thomas Mawson, Plan for the civic centre of Calgary (1914).

Fig. 9: The Toronto Guild of Civic Art, plan for Toronto. Includes provisions for park spaces and diagonal boulevards (1909).

Fig. 10: Vancouver Town Planning Commission, design for a new civic centre (1930).

Fig. 11: Aerial view of beautification and improvements at Niagara Falls, including the Oakes Garden Theatre at centre and the Rainbow Bridge and Gardens in the upper middle (1935-1941). Photo Credit: Mary J. Anderson, Tragedy and Triumph: Ruby and Thomas Baker McQuesten (Dundas: Tierceron Press, 2011). 
Fig. 12: Detail of the Rainbow Bridge Gardens at Niagara Falls including

Elizabeth Wyn Wood's relief sculpture, Wild Geese (c. 1940), in situ at the garden. Photo Credit: Mary J. Anderson, Tragedy and Triumph: Ruby and Thomas Baker McQuesten (Dundas: Tierceron Press, 2011).

Fig. 13: Frances Loring and Florence Wyle, stylized panels of Canadian flora from the Oakes Garden Theatre at Niagara Falls (c. 1940). Photo Credit: George Bailey.

\section{Chapter Two - How Reform Can Come to the Arts: The Canadian Allied Arts}

Fig. 14: George A. Reid, Mortgaging the Homestead (1890). $130.1 \times 213.3 \mathrm{~cm}$. Photo Credit: National Gallery of Canada.

Fig. 15: George A. Reid, The Arrival of the Pioneers in the Toronto Municipal Buildings (1897-1899). $213 \times 427 \mathrm{~cm}$.

Fig. 16: George A. Reid, Staking a Pioneer Farm in the Toronto Municipal Buildings (1897-1899). $213 \times 518 \mathrm{~cm}$.

Fig. 17: George A. Reid, Discovery, Fame, Fortune, and Adventure, Spandrel figures in the Toronto Municipal Buildings (1897-1899).

Fig. 18: Design for Victoria Square, Toronto (1897). Photo Credit: Mark Osbaldeston, Unbuilt Toronto: A History of the City That Might Have Been (Toronto: Dundurn Press, 2008).

Fig. 19: Installation photograph from the First Biennial Exhibition of Architecture and the Allied Arts at the Art Gallery of Toronto (1927).

Fig. 20: Frederick Challener, The Enchanted Wood mural series from the Parkwood estate, Oshawa (c.1925). Photo Credit: Parkwood National Historic Site.

Fig. 21: Frederick Haines, mural series in the entrance hallway at Parkwood depicting formal gardens (c. 1930). Photo Credit: Parkwood National Historic Site.

Fig. 22: Lorrie and Howard Dunington-Grubb, Sunken Garden at the Parkwood Estate, Oshawa (1927). Photo Credit: Julie Nash.

Fig. 23: Lorrie and Howard Dunington-Grubb, Italian Garden at the Parkwood Estate, Oshawa (1927). Photo Credit: Julie Nash.

Fig. 24: Detail of sculptural group in the Dunington-Grubbs' Italian Garden at the Parkwood Estate, Oshawa (c. 1927). Photo Credit: Julie Nash. 
Fig. 25: John Lyle, Formal Fountain and Garden at the Parkwood Estate, Oshawa (c.1935-1936). Photo Credit: Julie Nash.

Fig. 26: John Lyle, balcony and fountains of the Formal Fountain at the Parkwood Estate, Oshawa (c.1935-1936). Photo Credit: Julie Nash.

Fig. 27: Bronze Geese from the Formal Fountain at the Parkwood Estate, Oshawa (c.1935-1936). Photo Credit: Julie Nash.

Fig. 28: Head of Neptune from the Formal Fountain at the Parkwood Estate, Oshawa (c.1935-1936). Photo Credit: Julie Nash.

Fig. 29: John Lyle, Teahouse of the Formal Fountain at the Parkwood Estate, Oshawa (c.1935-1936). Photo Credit: Julie Nash.

Fig. 30: John Lyle, design for Colonel R.S. McLaughlin's bedroom at the Parkwood Estate, featuring a Stag and Doe relief panel (c. 1935). Photo Credit: Glenn McArthur, $A$ Progressive Traditionalist: John M. Lyle, Architect (Toronto: Coach House Books, 2009).

Fig. 31: John Lyle, design for Colonel R.S. McLaughlin's bedroom at the Parkwood Estate, including furniture pieces (c. 1935). Photo Credit: Stephanie Beatty and Susan Gale Hall, Parkwood (Erin: Boston Mills Press, 1999).

Fig. 32: Florence Wyle, Baby with Dolphin (c. 1923), in situ at the Parkwood Estate and Gardens, Oshawa. Photo Credit: Julie Nash.

Fig. 33: Sculptural Fountain in the Dunington-Grubbs' Sunken Garden at the Parkwood Estate. Photo Credit: Julie Nash.

Fig. 34: Frances Loring, Girl With Squirrel (c. 1922), in situ at the Parkwood Estate and Gardens, Oshawa. Photo Credit: Julie Nash.

\section{Chapter Three - Regional Beautification: Civic Art in Hamilton}

Fig. 35: Noulan Cauchon, plan for an amphitheatre in Hamilton (1917).

Fig. 36: Noulan Cauchon, map of streets and highways from Report on Mountain Highways of Hamilton, Ontario (1919).

Fig. 37: John Lyle, Gage Park Fountain, Hamilton (c. 1927). 
Fig. 38: Gage Park Fountain set against mountain scenery. Photo Credit: Glenn McArthur, A Progressive Traditionalist: John M. Lyle, Architect (Toronto: Coach House Books, 2009).

Fig. 39: Florence Wyle, Relief of Dancing Children (c. 1927). Photo Credit: Glenn McArthur, A Progressive Traditionalist: John M. Lyle, Architect (Toronto: Coach House Books, 2009).

Fig. 40: Map of Hamilton showing McMaster, Westdale and the Royal Botanical Gardens in 1931.

Fig. 41: Original design for McMaster University, Hamilton (1928). Photo Credit: Charles M. Johnston, McMaster University, the Early Years in Hamilton, 1930-1957 (Toronto: University of Toronto Press, 1981).

Fig. 42: The original Hamilton campus of McMaster University with the DuningtonGrubb Sunken Garden in the foreground (c.1930). Photo Credit: Hamilton Public Library, Special Collections.

Fig. 43: Lorrie and Howard Dunington-Grubb, Sunken Garden at McMaster University (1929). Photo Credit: Mary J. Anderson, Tragedy and Triumph: Ruby and Thomas Baker McQuesten (Dundas: Tierceron Press, 2011).

Fig. 44: Nearly completed Rock Garden at Royal Botanical Gardens, Hamilton (1931). Photo Credit: Royal Botanical Gardens.

Fig. 45: Fred Flatman, Iron Gates for Hendrie Park, Royal Botanical Gardens, Hamilton (wrought in 1931, installed in 1953). Photo Credit: Julie Nash.

Fig. 46: Wilson, Bunnell and Borgstrom, winning design for the northwestern entrance competition (c.1930). Photo Credit: Eric Arthur, "Awards in the Competition for a NorthWestern Entrance to the City of Hamilton," JRAIC 5, no. 4 (April 1928).

Fig. 47: John Lyle, third place design for the northwestern entrance competition including design for the new High-Level Bridge (c.1930). Photo Credit: Eric Arthur, "Awards in the Competition for a North-Western Entrance to the City of Hamilton," JRAIC 5, no. 4 (April 1928).

Fig. 48: John Lyle, Hamilton High-Level Bridge crossing the Desjardins Canal (c.1932). Photo Credit: Glenn McArthur, A Progressive Traditionalist: John M. Lyle, Architect (Toronto: Coach House Books, 2009).

Fig. 49: Toronto Entrance to the Queen Elizabeth Way including stylized 'ER' lamp standards and the Lion Monument (c.1940). Photo Credit: Christine Boyanoski, Loring and Wyle, Sculptors' Legacy (Toronto: Art Gallery of Ontario, 1987). 
Fig. 50: Cloverleaf interchange on the Queen Elizabeth Way (c.1940). Photo Credit: Robert M. Stamp, QEW: Canada's First Superhighway (Erin: Boston Mills Press, 1987).

Fig. 51: Tapestry showing the original appearance of the Queen Elizabeth Way upon completion in 1940 (according to the vision of Thomas McQuesten). Photo Credit: Whitehern Historic House and Garden.

Fig. 52: William Lyon Somerville, Henley Bridge ship prow at St. Catherines (1939). Photo Credit: Mary J. Anderson, Tragedy and Triumph: Ruby and Thomas Baker McQuesten (Dundas: Tierceron Press, 2011).

Fig. 53: William Lyon Somerville, the Lion Monument in Sir Casimir Gzowski Park in Toronto (where it was relocated in 1975 when the Queen Elizabeth Way was expanded). Photo Credit: Julie Nash.

Fig. 54: Frances Loring, Imperial Lion from the Lion Monument (c. 1940). Photo Credit: Julie Nash.

Fig. 55: R.C. Reade, "Hamilton Shows Toronto How" (1929), with diagram of Hamilton's improvements to the northwestern entrance. 
Introduction - Statement of the Research Problem

"There can only be one successful civic art ... one which joins utility to beauty."

"To make us love our city we must make our city lovely."

- Charles Mulford Robinson, 1903

Global reform phenomena at the turn of the twentieth century inspired Charles Mulford Robinson's (1869-1917) seminal monograph, Modern Civic Art; or, the City

Made Beautiful. Robinson concluded that the city and the arts, or utility and beauty, are inevitably and necessarily allied through civic art.

This thesis explores the parallels between the city planning movement and the proliferation of Canadian civic art. Civic art resulted from the escalation of city planning theory and practice in the 1890 s, which emerged as a variant of European urban reform. The self-professed purpose of city planning was to revitalize the sanitation, morality, physical appearance and organization of cities, according to the ideals that beauty cultivates ethical civic behaviour and generally improves lives. Although influential in terms of urban beautification, grandiose reform projects were eventually discontinued due to their cost.

Civic art was contiguous to the reform of the city planning movement. In the broadest sense of the term, the discipline of 'civic art' as explored in this thesis comprises a series of features that were seemingly inherent to the modern city in the latter half of the nineteenth century and well into the twentieth century. These included beautified public spaces, and sophisticated, efficient physical infrastructure. 'Civic art' in its fullest sense - that which is elucidated in this thesis - thus comprises familiar fine art such as mural painting, public sculpture, monuments and architecture, in addition to landscape 
design, systematized city planning, urban sanitation, and coherent traffic systems.

All of these are united and symbiotic in the discipline of civic art.

The publications of Charles Mulford Robinson and his colleague, British town planner Thomas Mawson (1861-1933), facilitated the proliferation of civic art. While the concept of civic art is expansive and amorphous, Robinson, Mawson and their contemporaries agreed about its function. Robinson defined civic art as harmony between beauty and utility; Mawson agreed that beauty could not be segregated from utility. As Mawson wrote: "The aim of civic art, as distinct from the practical, is to educate, to train the vision to see beauty in every line drawn, in the design of every structure, in every tree planted, and in every stretch of greensward laid down ... [in sum] the aesthetics of town planning." 3

Homogeneity existed between the city planning phenomenon and the civic art movement because both celebrated the comprehensive, unified modern city: both movements sought to rectify the perceived ills of industrialization. The result was an alliance between the different approaches to city planning, including the City Beautiful, Social Gospel and Progressivism, and City Scientific movements.

In the first two decades of the twentieth century urban beautification and improvement proposals proliferated across Canada. However, due to a paucity of comprehensive planning and financial resources, beautification projects were often aborted or curtailed. Canadian civic art was advertised through exhibitions and publications, but predominantly through completed civic art projects. An unparalleled example of Canadian civic art appeared in Hamilton, Ontario during the 1920s and 1930s. The city underwent an intensive program of civic beautification and improvement, 
with comprehensive projects spanning from infrastructure improvements to the beautification of public parks and roads.

The city planning phenomenon engendered Canadian civic art: professionals utilized the escalating popularity of the former to promote reformed, civic-focused Canadian art. Civic art in Canada manifested itself as beautification projects informed by the ethos of the City Beautiful, Social Gospel, Progressivist, and City Scientific movements. Beautification and improvement proposals that appeared across Canada in the first decades of the twentieth century document regional approaches to the shared paradigm of civic art and the city planning phenomenon: the amalgamation of beauty and utility in public works.

\section{Chapter Breakdown}

\section{Chapter One -}

\section{The City Planning Movement and the Awakening of Canadian Civic Art}

Chapter One of this thesis introduces how and why social reform was enacted when nineteenth-century industrialization was perceived to threaten the health of cities. Accordingly, this chapter includes a brief overview of the origins of the city planning phenomenon, demonstrating how a variety of movements and ideologies coalesced into what, in the twentieth century, would be recognized as comprehensive urban planning. This includes a study of the City Beautiful movement, and examples within Canada including Mount Royal Park in Montreal, Edward Bennett's plan for Ottawa, and Thomas Mawson's design for Calgary. Also considered will be the late nineteenth-century and early twentieth-century Progressivist social movements, including the Social Gospel 
movement. This is followed by a review of the City Beautiful's counterpart, the City Scientific, and the ramifications the latter held for reform.

Part of Chapter One consists of brief overviews of the key individuals involved in the spread of the City Beautiful, City Scientific, and civic art phenomena. Notable figures include civic art advocates Charles Mulford Robinson and Thomas Mawson, landscape architect Frederick Law Olmsted, Sr., sculptor Lorado Taft, and town planners Thomas Adams, Noulan Cauchon, and Edward Bennett.

\section{Chapter Two - How Reform Can Come to the Arts: The Canadian Allied Arts}

The second chapter of this thesis reviews the historical development of the Canadian allied arts movement rather than the theoretical underpinnings of the city planning phenomenon. Applying the model of comprehensive planning from Chapter One, this chapter explores how the fine arts were united across disciplines as the allied arts: a network of collaboration by Canadian professionals.

Chapter Two thus establishes how the city planning phenomenon's collaborative program of civic reform was reflected in the work of artists, designers, architects and art organizations for a period of approximately fifty years (1889-1939). Prominent examples that I will discuss include George Reid's murals in the Toronto Municipal Buildings, and John M. Lyle's design of the garden at the Parkwood Estate in Oshawa. An analysis of the allied arts in Canada also necessitates a review of the Biennial Exhibitions of Architecture and the Allied Arts held at the Art Gallery of Toronto from 1927 to 1939 , as well as a consideration of influential historical publications on the same subject. 


\section{Chapter Three - Regional Beautification: Civic Art in Hamilton}

My final chapter consists of an exemplary case study that illustrates the collaborative efforts of civic art in Hamilton, Ontario, which sponsored a series of beautification projects from 1920 to 1939 . Following the themes of beautification, edification and traffic circulation, this study will illustrate how public, accessible, morally inspiring and practical spaces were the primary products of collaborative city planning, and embody the combination of beauty and utility promulgated by Charles Mulford Robinson and others. The example of Hamilton also demonstrates how the ideals of city planning and civic art were realized in a single city, through a number of projects including the implementation of park spaces, the formation of McMaster University's Hamilton campus and Canada's first botanical garden, and the construction of Canada's first superhighway, the Queen Elizabeth Way.

\section{Literature Review}

An investigation of the city planning and civic art movements in Canada necessitates a balanced use of historical texts and contemporary scholarship. This twofold perspective will contextualize the interdisciplinary nature of this thesis, which encompasses Canadian art history, civic art theory and town planning ideology. Accordingly, the following literature review has been divided into three sections that discuss relevant historical and contemporary resources for each chapter. 
Chapter One -

The City Planning Movement and the Awakening of Canadian Civic Art

The city planning movement appeared in response to reform. A series of specialized planning movements including the City Beautiful, Garden City, Social

Gospel, Progressivism, and City Scientific efforts which manifested themselves in this period, yet each is commonly treated as an isolated phenomenon in both historical and contemporary scholarship.

Two essential books on the subject of civic art are Charles Mulford Robinson's Modern Civic Art; or, the City Made Beautiful (1903) and Thomas Mawson's Civic Art (1911). These were the first publications to link twentieth-century beautification projects with the dissemination of civic art, a concept that is fundamental to this thesis. They also follow the formula established by town planning texts that introduce the ideology of the subject, followed by a selection of case studies. Another essential text about civic art is The American Vitruvius: An Architect's Handbook of Civic Art by Werner Hegemann and Elbert Peets (1922), which endorses the collaborative effort sought between different factions of the arts. Together these books offer an introduction to the historical realization of civic art.

Texts discussing landscape architect Frederick Law Olmsted and the construction of Mount Royal Park are used in this thesis to segue to an early appearance of large-scale Canadian city planning; namely, the City Beautiful. The construction of Mount Royal park has been researched using A.L. Murray's "Frederick Law Olmsted and the Design of Mount Royal Park, Montreal" (1967); Nancy Pollock-Ellwand's “The Olmsted Firm in Canada" (2008), and "Rickson Outhet: Bringing the Olmsted Legacy to Canada. A 
Romantic View of Nature in the Metropolis and the Hinterland" (2010); George L. Scheper's "The Reformist Vision of Frederick Law Olmsted and the Poetics of Park Design" (1989); and Irving D. Fisher's Frederick Law Olmsted and the City Planning Movement in the United States (1986). Two seminal M.A. theses that have informed this discussion of Olmsted's Mount Royal project are Janice Seline's "Frederick Law Olmsted's Mount Royal Park, Montreal: Design and Context" of 1983 and Lawrence Peter Kredl's “The Origin and Development of Mount Royal Park, Montreal, 1874-1900: Ideal vs. Reality," also from 1983.

Historical texts concerning the City Beautiful movement tended to praise utopian ideology and overlook the ramifications of redeveloping heavily populated urban centres. One of the most comprehensive resources on the City Beautiful was Daniel Burnham and Edward Bennett's Plan of Chicago from 1909. This text followed Burnham's highly successful design for the Chicago World's Exposition in 1893, where the City Beautiful movement first manifested itself in North America. Another advocate of town planning was Thomas Adams, who in addition to several published articles released Outline of Town and City Planning, A Review of Past Efforts and Modern Aims in 1936.

One collection of historical documents fundamental to a study of the city planning phenomenon are the proceedings from a series of conferences held throughout the United States and Canada. The lectures and discussions from the National Conferences on City Planning (1909-1924) provide unparalleled evidence of the ethos fashioned by the town planners, architects, engineers, economists, politicians and artists who advocated for beautification. Pivotal lectures from these conferences include George B. Ford's "The City Scientific" (1913); G. Trafford Hewitt's "Canada and the United States as a Field for 
the Garden City Movement" (1914); Frederick L. Ackerman's “The Architectural Side of City Planning" (1915); and Thomas Adams' "The Beginnings of Town Planning in Canada" (1916).

Significant advances in the scholarship of the City Beautiful movement have materialized in recent years. The most comprehensive contemporary resource is William H. Wilson's The City Beautiful Movement from 1989. This monograph reviews both the historical origins of the movement and the ideology behind its inception. Recently, however, scholarship on this topic has developed a critical outlook. Contemporary texts, including Gilbert A. Stelter's "Rethinking the Significance of the City Beautiful Idea" (2000), argue that the movement was a positive force in modern society.

Contemporary literature concerned with the course of the City Beautiful in Canada includes "The Fate of City Beautiful Thought in Canada, 1893-1930" by W. Van Nus (1975), and Nancy B. Bouchier and Ken Cruikshank's essay, "The War on the Squatters, 1920-1940: Hamilton's Boathouse Community and the Re-Creation of Recreation on Burlington Bay" (2003). The latter is especially pertinent to this thesis as it condemns City Beautiful efforts in Hamilton, Ontario, particularly the rejuvenation of the city's Northwestern Entrance in the 1920s: a topic discussed in Chapter Three.

Seminal monographs about the City Beautiful's auxiliary religious movement, the Social Gospel, include Donald K. Gorrell's The Age of Social Responsibility: The Social Gospel in the Progressive Era, 1900-1910 (1988); Willem Visser'T Hooft's The Background of the Social Gospel in America (1928); and Ronald C. White and C. Howard Hopkins' The Social Gospel: Religion and Reform in Changing America (1976). These pivotal texts establish connections between urban reform and aesthetics, and 
provide accounts of the trends that informed the city planning movement in

Canada. They are complemented by studies of Progressivism, such as Arthur S. Link and Richard McCormick's Progressivism of 1983.

Further contemporary scholarship apropos the city planning movement includes David Gordon's articles, “A City Beautiful Plan for Canada's Capital: Edward Bennett and the 1915 Plan for Ottawa and Hull" (1998), and "'Agitating People's Brains': Noulan Cauchon and the City Scientific in Canada's Capital" (2008). Another significant essay is Nicholas Terpstra's "Local Politics and Local Planning: A Case Study of Hamilton, Ontario, 1915-1930" (1985) which offers an account of how a single city encountered the many manifestations of city planning. These texts establish a model for the investigation of individual people or forms of city planning (especially in a single city), which this thesis applies to the development of comprehensive city planning and civic art in Canada.

\section{Chapter Two - How Reform Can Come to the Arts: The Canadian Allied Arts}

Historical literature pertinent to the subject of civic art encompasses written material by architects, artists, and town planners. A particularly prolific author was John M. Lyle, whose articles about Canadian architecture encouraged integration between the arts, town planning, engineering, and architecture. A notable example for this thesis is his “Civic Beautification" from 1928. Fellow architect William L. Somerville's essay, "Why the Interior Decorator?" (1932) argued that the architect should design both the inside and outside of a building.

This thesis utilizes art historical texts to reconstruct the trends of the period and the work of individual professionals. For example, texts investigating artist George Reid 
review the early history and style of civic art in Canada. Relevant sources include Sympathetic Realism: George A. Reid and the Academic Tradition by Christine Boyanoski (1986); G.A. Reid, Toward a Union of the Arts by Chris Dickman (1985); George Reid, A Biography by Muriel Miller (1946); and Rosalind Pepall's 1982 M.A. thesis, "The Murals by George A. Reid in the Toronto Municipal Buildings, 1897-1899." Historical essays written by Reid himself include "Architecture from an Artist's Standpoint" (1891) and "Applied Art" (1900). Other publications by Reid disclose the early history of civic art in Canada, particularly his notes on the mural decorations he completed for the Toronto Municipal Buildings from 1897 to 1899 . Pertinent essays include "Mural Decoration" (1898) and "Mural Decorations in the New Municipal Buildings, Toronto" (1899). These are complemented by essays written by other members of the Toronto Guild of Civic Art, including James Mavor's "Note on the Objects of the Toronto Guild of Civic Art and on the Exhibition of Prints of Mural Paintings" from 1898. This chapter also utilizes historical articles to contextualize the proliferation of aesthetic unity. For example, Hamilton MacCarthy's "The Aesthetic Unity of the Fine Arts - Most Especially in Relation to Architecture" (1895) is an early reference to unity in Canadian fine art.

In order to reconstruct the history of the Biennial Exhibitions of Architecture and the Allied Arts, this thesis utilizes the seven catalogues published in conjunction with the shows from 1927 to 1939 . Further information regarding the public and critical reception of these exhibitions is available from exhibition reviews, particularly H.M. Ridley's “Canada's Architectural Movement, 'The Diet Kitchen' School and Its Propaganda for the Art" (1927). Other valuable articles include John Lyle's "The Allied Arts at the 
Recent Toronto Chapter Exhibition” (1927); Arthur Eadie's "Whither Are We Bound?" (1933); and Canadian Homes and Gardens' "Notes from the Architects' Show" (1933).

This thesis utilizes Parkwood by Stephanie Beatty and Susan Gale Hall (1999) to reconstruct the application of the allied arts at Parkwood, home of auto baron R.S. McLaughlin in Oshawa. Likewise, publications about John Lyle are utilized to assess his specific design projects at the estate. These include Geoffrey Hunt's John M. Lyle, Toward a Canadian Architecture (1982); Glenn McArthur's A Progressive Traditionalist: John M. Lyle, Architect (2009); and Trevor Boddy's "Regionalism, Nationalism, and Modernism: The Ideology of Decoration in the Work of John M. Lyle" (1981).

Further significant articles by Canadian artists include Frances Loring's essay "Sculpture in the Garden" from Canadian Art magazine (1943). Loring argues in favour of the placement of sculpture in formal gardens, an opinion that was first expressed by landscape architect Lorrie Dunington-Grubb in "Sculpture as a Garden Decoration" (1927). A final historical resource on the subject of Canadian civic art is the 1928-1929 edition of the Yearbook of the Arts in Canada. This text contains articles discussing the trends in Canadian art at a pivotal moment in history. A particularly useful essay from this publication is Emanuel Hahn's "Sculpture in Canada." A second article by Hahn applied in this chapter is his "Architectural Sculpture" (1932). These are complemented by an essay by Hahn's wife, fellow sculptor Elizabeth Wyn Wood, entitled “Observations on a Decade ... 1938-48: Ten Years of Canadian Sculpture" (1948). These historical essays contextualize the application of unity to the Canadian fine arts. 


\section{Chapter Three - Regional Beautification: Civic Art in Hamilton}

The final category of literature utilized in this thesis comprises resources discussing civic art in Hamilton, the case study covered in Chapter Three. In this chapter, the historical sources are drawn from those discussed in sections one and two above. In addition, each subdivision of this chapter also necessitated the use of contemporary scholarship that does not address either city planning or civic art, but rather the monument or structure in question. Finally, a large portion of this chapter is informed by clipping scrapbooks on specific civic art projects in Hamilton. These are available from the Special Collections department of the Hamilton Public Library.

Noulan Cauchon's series of three reports on development in Hamilton form a significant portion of the literature utilized in this chapter, especially his Reconnaissance Report on Development of Hamilton, Ontario from 1917. Furthermore, references to the individual projects featured in each subsection were sought in texts such as Leslie Laking's 2006 history of Hamilton's Royal Botanical Gardens, entitled Love, Sweat and Soil, A History of Royal Botanical Gardens from 1930 to 1981. Laking reveals how the relocation of McMaster University (originally situated in Toronto) was part of a grand beautification scheme for Hamilton. This text, when accompanied by Charles M. Johnson's history of McMaster, McMaster University, The Early Years in Hamilton, 1930-1957 (1981), reconstructs the history of a specific civic art undertaking in Hamilton. This thesis revisits the history of Hamilton's High-Level Bridge and the construction of the Queen Elizabeth Way through contemporary texts such as Robert Stamp's QEW: Canada's First Superhighway (1987), and John C. van Nostrand's “The Queen Elizabeth Way: Public Utility Versus Public Space” (1983). 
Especially in Chapter Three, this thesis consulted monographs concerned with individual people, artists, locations or projects to rectify any gaps that were missing from the archival research. For instance, narratives of the life of politician and beautification enthusiast Thomas B. McQuesten assist in the discussion of the reconstruction of the civic art movement in Hamilton. These include Thomas Baker McQuesten: Public Works, Politics and Imagination by John C. Best (1991); and Tragedy and Triumph: Ruby and Thomas Baker McQuesten by Mary J. Anderson (2011). The history of artists involved in the case studies is available through art historical texts including Christine Boyanoski’s Loring and Wyle, Sculptors' Legacy (1987).

The last segment of contemporary scholarship that is relevant to this chapter is the research of Joan Coutu, which addresses the renovation of the Niagara parks system by Thomas Baker McQuesten. Her relevant essays include: “A Drive Through Canadian History: People, Cars and Public Art at Niagara Falls in the 1930s" (2009); "Vehicles of Nationalism: Defining Canada in the 1930s" (2002); and her 1989 M.A. thesis, "Design and Patronage: The Architecture of the Niagara Parks 1935-1941." Coutu's triad of publications has created a model for study of beautification projects in a single city.

\section{Methodology}

This thesis is an interdisciplinary study that connects international city planning movements with manifestations of civic art in Canada. As such, it incorporates a number of interrelated yet apparently disparate disciplines. These include aesthetics, moral reform and practicable city planning, which together create a comprehensive discussion of civic art. My thesis seeks to contextualize civic art through an inclusive discussion of a number 
of authoritative movements, including the City Beautiful, the Social Gospel and Progressivism, and the City Scientific. As such this thesis assembles a number of approaches to reform in order to examine the complex and cross-disciplinary phenomenon of comprehensive city planning, or, civic art.

Furthermore, this thesis is structured so as to transition from an investigation of the theoretical underpinnings of city planning to a discussion of realized civic art projects. Chapter One deals almost exclusively with the theories of the city planning phenomenon and civic art, while Chapter Two incorporates these with studies of unity in the traditional fine arts. These culminate in Chapter Three with a discussion of city planning theory put into practice as Canadian civic art, through a study of the systematic beautification of Hamilton. Thus, this thesis is structured to transition from the abstract to the concrete, to draw attention to both the theory and the reality of civic art in Canada.

As a result of the historical perspective adopted throughout this project, archival research was pivotal to my thesis. My research accessed archival sources in Hamilton, including those at Hamilton's Public Library and McMaster University. At the Special Collections department of the Hamilton Public Library I reviewed Noulan Cauchon's series of three urban planning reports on Hamilton. At the same location, I accessed clipping files on a number of civic art projects in Hamilton, including Gage Park, Royal Botanical Gardens, McMaster University, the High-Level Bridge, and a general file on city planning in Hamilton. This thesis also necessitated archival research at McMaster University, particularly the journals of the Royal Architectural Institute of Canada. These provided context for the architectural side of city planning from 1920 to 1939 . 
This thesis also involved site visits to view the civic art projects that are reviewed throughout the text. This necessitated travel to Toronto to view George Reid's murals in the Municipal Buildings and the Lion Monument, to Oshawa to visit the Parkwood Estate, and Hamilton for Gage Park, Royal Botanical Gardens, McMaster University and the High-Level Bridge. 


\section{Endnotes to Introduction}

${ }^{1}$ Charles Mulford Robinson, Modern Civic Art, or, the City Made Beautıful 1903 (Reprint, New York Arno Press, 1970) 29

${ }^{2}$ Ibid 35 This was the motto of the Mumcipal Art Society of New York, and is adopted by Robinson to promote civic pride through civic art

${ }^{3}$ Thomas Mawson, preface to Clvıc Art Studies in Town Planning, Parks, Boulevards and Open Spaces (London B T Batsford, 1911) 
Chapter One -

The City Planning Movement and the Awakening of Canadian Civic Art

"The question properly arises as to what municipal art is. Granted that the progressive modern city develops gradually in beauty and splendour, is this normal improvement, which is more or less haphazard, civic art?"1

- Charles Mulford Robinson, 1903

When Charles Mulford Robinson set out to discuss civic art in his 1903

monograph Modern Civic Art; or, the City Made Beautiful, he introduced his discourse through this query. In it, Robinson captured the inherent development of civic art, namely, that the discipline was a natural byproduct of the growth of modern cities. Civic art in its broadest sense - that which is applied in this thesis - consists of all the fundamental elements of the city. In addition to recognized traditional fine arts such as mural paintings, sculpture and architecture, these include infrastructure, such as town planning, roadways and engineering.

The relationship between civic art and the modern city cannot be divorced from the influence of urban reform at the end of the nineteenth century. Reformists worldwide sought to rectify the perceived ills of the industrialized city through a program of reengineered infrastructure and the insertion of beautified civic spaces into urban centres. Furthermore, just as the physical manifestations of urban beautification and improvement differed between continents and cities, the broader impulses motivating each were diverse. City planning movements were essential to the development of Canadian civic art; it was the collaboration of these progressive interest groups that advocated for the inclusion of the arts within urban development.

Any discussion of modern civic art at the turn of the twentieth century would be ineffectual without acknowledging that a consensus about what it entailed was never fully 
realized (hence the statement in the first paragraph of this chapter defining the use of the term throughout this thesis). In its many manifestations across North America and Europe (as well as across centuries), civic art was adapted to the ethos and cultural needs of each location, thus rendering it amorphous and elusive. Indeed, it can be argued that the breadth of this field resulted in the simultaneous co-existence of many divergent opinions about its nature and purpose. Contemporary scholar Nicholas Terpstra has demonstrated that, for the years covered by this thesis, the civic conditions within each community were as authoritative to the implementation of civic art as the nation-wide force of the city planning movement: "Developments ... such as the pre-[World War One] shift from beautification to efficiency may find only ambiguous reflection at the local level." 2 This is because national-level city planning commissions engineered grandiose plans, whereas localized planning bodies focused on achievable beautification and improvement projects. ${ }^{3}$

In addition, at the beginning of the twentieth century civic art was reaching a new magnitude at the international level:

By the time Robinson was writing, civic art - and its equivalents under many different terms including art public, art civique, art urbain, civic design, and municipal art - was truly part of an international public discourse, a result of the robust exchange achieved through exhibitions, conferences, publications, speaking tours and formal partnerships forged between key European and American figures. The international scope of the movement was apparent in Robinson's Modern Civic Art. ${ }^{4}$

One illustration of the international range of civic art is the work of British town planner Thomas Mawson, who has been described as a "promoter of the notion of town planning as civic art." He proposed a succinct definition of civic art, namely: "The aesthetics of town planning." Mawson had a considerable influence in North America and eventually 
traveled the continent with an extensive publicity program advocating landscape

architecture and civic art. ${ }^{7}$ British town planner Raymond Unwin (1863-1940), in turn, defined civic art as follows:

Civic art is too often understood to consist in filling our streets with marble fountains, dotting our squares with groups of statuary, twining our lamp-posts with wriggling acanthus leaves or dolphins' tails, and our buildings with meaningless bunches of fruit and flowers tied up with impossible stone ribbons ... In desiring powers for town planning our town communities are seeking to be able to express their needs, their life, and their aspirations in the outward form of their towns, seeking as it were, freedom to become the artists of their own cities, portraying on a gigantic canvas the expression of their life. ${ }^{8}$

Mawson and Unwin's civic art shared a heritage with the British anti-industrialist Arts and Crafts movement (1880-1910) pioneered by William Morris (1834-1896), and the housing interests of Ebenezer Howard's (1850-1928) Garden City model (introduced in 1898). The Garden City was concerned with housing and land reform, ${ }^{9}$ and advocated for "building a town with a comprehensive and definite plan and with foresight, as opposed to the go-as-you-please growth of the modern city." that North American manifestations of the Garden City movement would provide "suitable homes for working men and their families at prices that are not absurdly above the means of the average worker." an ideal setting for Garden City reform was G. Trafford Hewitt, president of The Province of Nova Scotia Land Corporation Limited. Hewitt advised in favour of Garden City planning at the Sixth National Conference on City Planning (1914) in Toronto, "before property in these cities becomes too congested and valuable." Although not envisioned in the same 'grand manner' as the City Beautiful movement, ${ }^{13}$ the Garden City (which tended to focus on designing new towns and suburbs rather than on 
rethinking existing cities) was intended to solve the ills associated with industrialized urban growth by means of unified planning.

However, although figures such as Hewitt were active during the twentieth century, there was a general lack of detailed analysis of civic art prior to the progressive publications of Charles Mulford Robinson in the United States. His text Modern Civic Art; or, the City Made Beautiful of 1903 was preceded by The Improvement of Towns and Cities; or, the Practical Basis of Civic Aesthetics (1901). These titles delineate the inherent connection he identified, and that this thesis has adopted, between city planning and civic art (often straightforwardly defined as beautification in this period).

Over the course of his second monograph on civic art, Robinson encountered the amorphous categorization that plagued the discipline. Conceptually, Robinson held that civic art consisted of "the great art that is of the people and for the people, that is closest to their lives ... this art of doing civic things in the right way, which is ever the beautiful way." ${ }^{14}$ He also maintained: "There can only be one successful civic art. This will be one which joins utility to beauty." 15 In the tangible realm of the modern city, Robinson's definition of true, effectual civic art delineated three crucial things for which civic art had to make provision: "The function of civic art is the making of artistic - which is to say, of aesthetically pleasant - provision for the circulation, for hygiene and for city beauty."16 These sentiments were reiterated in the Toronto Guild of Civic Art's 1909 plan for Toronto, in which the Guild delineated the liabilities of unrestrained expansion:

American cities, while not burdened with the historic legacies of their European sisters, were until the last twenty years [1889-1909] heedless of anything but commercial gain, that they simply grew, proud only of their numerical strength, until all the evils of city life developed. Now a wave 
of civic improvement is passing over the country, striving hard against the difficulties that have become enormous. ${ }^{17}$

Civic art was thus conceptualized as long-term progress towards widespread civic improvements. This remainder of this chapter examines civic beautification and improvement projects, as well as prevalent ideologies from the decades around the early twentieth-century publication of Robinson's key texts. These projects included landscape planning (examined here through the lens of Mount Royal Park), the City Beautiful movement, the Social Gospel and Progressivist movements, the Toronto Guild of Civic Art, and the City Scientific movement. All of these diverse but teleologically related phenomena fed into the larger concept of civic art that was presented to North American audiences by Charles Mulford Robinson at the turn of the twentieth century.

\section{Mount Royal Park, Montreal, 1874-1877}

Fine arts based beautification and improvement projects under the city planning phenomenon were anteceded by urban planning efforts that cultivated the standards of the movement. One of Canada's first material examples of urban beautification was Frederick Law Olmsted, Sr.'s (1822-1903) design for Mount Royal Park in Montreal, which exemplified several aspects of the City Beautiful movement (Fig. 1). Olmsted was an American landscape architect who abided by the concepts of cohesive design and organic growth, and was recognized in North America for his co-design (with Calvert Vaux) of New York City's Central Park in 1858. He was also responsible for the landscape architecture featured at the Chicago World's Exposition in 1893. Olmsted's designs were guided by the principle that a park was "an antidote to the ills of the city.", 
His park designs anticipated the work of modernist architects, whose 'form follows function' idiom governed the design of efficient architectural spaces. ${ }^{19}$ This theory was central to Olmstedian designs, which must be appreciated both for their formal features (the physical appearance of the park) as well as "the intended function that ultimately determined the park's form." 20

Olmsted was the foremost pioneer of North American landscape architecture in the nineteenth century. Having himself titled the vocation, he effectively upgraded vernacular landscape architecture from a dilettante interest in gardening to a profession. He wrote:

Landscape Architecture is the application or picturesque relation of various objects within a certain space, so that each may increase the effect of the whole as a landscape composition. It thus covers more than landscape gardening. It includes gardening and architecture and extends both arts, carrying them into the province of the landscape painter. In all landscape architecture there must not only be art, but art must be apparent. $^{21}$

Olmsted was adamant that the principle task of the profession was to follow the original form of the landscape, thus enhancing the natural design of the site. This conviction intersects with the organic principle of the City Beautiful, which was explained in the nineteenth century as "the organic process of the spontaneous outward unfolding from an inner vital seed or root."22 (See next section). This romantic vision of the environment preserved the morality associated with the unhindered natural world.

Indeed, Olmsted romanticized the landscape architect's responsibility to nature:

Olmsted claimed that the landscape architect creates beauty in nature by epitomizing and idealizing it through his genius. He reformulates it as a landscape painter would by selecting, leaving out, and including. This way the artist removes the blots of ugliness, decay, and enfeebled forms and progresses towards a harmonized conception of natural beauty. ${ }^{23}$ 
In addition to his vision of the landscape architect gently cultivating nature to its maximum potential, Olmsted's definition of the profession revealed his loyalty to aesthetic unity. For example, in reference to his design for Mount Royal Park he analogized that the park was a "sustained landscape poem,",24 in which "each separate section of the park [is congruent] to a stanza of a poem, which when completed makes an integrated whole." ${ }^{25}$ Furthermore, with unity came an inherent equilibrium, as "park promoters ... held a Romantic view of nature and took steps to ensure there was a balance between the artificial city environment and nature. ${ }^{26}$ Olmsted's adherence to unity in his designs was only one of three fundamental principles by which he abided. The other two included faith in the therapeutic power of the environment, and a belief that the natural conditions of the site should be respected in the design. ${ }^{27}$ These features became important considerations in beautification reform and in civic art.

Montreal's incentive to create a formal public park out of city property manifested in the second half of the 1800 s as cities throughout North America and Europe acquired green spaces. These were considered "symbols of health, a democratic society and civic beauty and progress." ${ }^{28}$ Moreover, an urban park had a tourism component that would enhance the city's economic standing in the country. ${ }^{29}$ Olmsted's preliminary commission for Mount Royal included the directive that he should fabricate a park from the eight topographical zones found at the site. ${ }^{30}$ The location was selected as a result of its abundant natural scenery, including plentiful vantage points overlooking the city. ${ }^{31}$ Indeed, these were of such a high quality that Olmsted construed the scenery as the site's finest asset, encouraging Montreal officials to embrace the mountain-like features of the location. ${ }^{32}$ This involved retaining the original formation of the eight topographical 
zones, and utilizing the unique features of each in the selection and situating of complementary plants. The result of this plan was that "Olmsted hit upon a great design idea - make the mountain look taller, more mountainous. This concept allowed for a natural degree of variety while it enhanced the overall impressiveness of the site; the high parts would seem appropriately higher, the low parts lower."33

The Mount Royal Park commission specified numerous items that Olmsted was required to incorporate into his design, including provisions for water and roadways. ${ }^{34}$ Olmsted insisted that the roads should follow the spontaneous unfolding of the site rather than cut through natural features. ${ }^{35}$ As a result, the final design submitted in 1877 (and published as a pamphlet in 1881) consisted of "an agglomeration of groups of plans presented by the architect in response to specific requirements." ${ }^{36}$ It is therefore perhaps not surprising that the end result was not harmonious with Olmsted's preferences for landscape architecture; namely, "art to conceal art,"37 in which the impression of the whole overrides that of the individual components. Certainly, Olmsted's preferences for landscape design contradicted "a piecemeal approach to landscape design ... [he] fought to overcome its consequences in the overall design." 38

The design of Mount Royal Park coincided with early Canadian town planning efforts, as it addressed the same recreation and environmental concerns engendered by industrialization. ${ }^{39}$ Although the number of Olmsted's completed projects in Canada is small, ${ }^{40}$ his theories had a lasting impact on the first major generation of Canadian town planners. This was due in part to correspondence between the American-based Olmsted firm and town planners across Canada, and to three members of Olmsted's American firm (Frederick G. Todd, Gordon Culham and Rickson Outhet) who moved to Canada 
and established their own practices. ${ }^{41}$ The Olmstedian "search for the rejuvenating force of scenic beauty ${ }^{, 42}$ remained a motivating force for Canadian town planners well into the twentieth century. This is confirmed by the fact that for several decades following the Mount Royal project, the Olmsted firm was employed by Canadian cities and wealthy private patrons to produce ambitious civic plans and improvements to private mansions. ${ }^{43}$ Indeed, although Olmsted himself was not directly associated with the movement, his environmentalist philosophy often mirrored that of the City Beautiful. ${ }^{44}$ Certainly, many scholars believe that Olmsted "bequeathed" his aesthetic ideology to the City Beautiful, most notably the notion of unified planning. ${ }^{45}$

\section{The City Beautiful}

The most perceptible and enduringly familiar manifestation of North American reform at the end of the nineteenth century was the City Beautiful movement (approximately 1890-1914). It appeared as enthusiasm for beautified urban spaces matured during the last decade of the nineteenth century. As noted above, public fervor for the City Beautiful was due in part to the work of nineteenth-century landscape architects including Olmsted, and to a proliferation of beautification designs for community spaces. In essence, the City Beautiful movement was an environmentalist urban planning phenomenon emphasizing aesthetically enhanced civic centres, parks, and natural vistas, "the avoidance of visual monotony," and aesthetic coherence. ${ }^{47}$ Its goal was to improve the morale and quality of life of jaded urban dwellers. 
The City Beautiful was derived from the theory that the city is both a work of art and an organism requiring comprehensive planning. ${ }^{48}$ Thus the movement accounted for the entire city, ${ }^{49}$ much as landscape architecture accounted for entire natural spaces:

The necessity of extending the architect's sphere of influence, to emphasize the essential relation between a building and its setting, the necessity of protecting the aspect of the approaches, the desirability of grouping buildings into harmonious ensembles, of securing dominance of some buildings over others, so that by the willing submission of the less to the greater there may be created a larger, more monumental unity; a unity comprising at least a group of buildings with their surroundings, if possible entire districts and finally even, it may be hoped, entire cities. ${ }^{50}$

The City Beautiful movement emulated the rejuvenation of European cities, including the Haussmannization of Paris during the Second Empire (1852-1870), and the construction of the Vienna Ringstrasse (begun in 1857). The City Beautiful movement was thus North America's version of planning in the 'grand manner' first espoused by European reform. ${ }^{51}$ The features of grand manner planning included "geometric order; long, straight streets culminating in vistas; formal squares and places; elaborate parks; and the ability to link all of these elements into one coherent whole." 52 The Parisian remodeling under Napoleon III became the paradigm of the modern city, partly because of the amalgamation of aesthetic and scientific facets of town planning. ${ }^{53}$ For example, Baron Haussmann (1809-1891) situated the Paris Opéra (designed by Charles Garnier, 1858-1872) at the intersection of several large thoroughfares (Fig. 2), such that it symbolized "the heart of the city, emanating the pulse of the organism." Haussmann's carefully planned city was in actuality a façade concealing the realities of large-scale urban renovation, ${ }^{55}$ such as loss of housing for the urban poor. These were 
concerns that comprehensive city planning would address. Coherence became the rationale of the City Beautiful: "No longer should beauty be confined to scattered and isolated buildings, its effect more often than not spoiled by an ugly setting. Instead, professionals would plan and regulate the entire city so that people might be surrounded by beauty." 56

Unified civic beauty as embodied in grand manner planning was but one reason why the public espoused the City Beautiful movement. By observing images of the modern Parisian city as presented at the Paris Universal Exposition in 1889 and the 1893 World's Columbian Exposition in Chicago, the North American public embraced the unified planning ideology associated with the city planning movement. Indeed, shortly after the close of the Chicago fair in October 1893, Charles Mulford Robinson noted the beautification legacy of this event: "The higher ideal for public structures is [partly] ... due to the influence of the expositions. The Centennial and World's Fair were wonderful artistic stimulants to the nation at large. ${ }^{, 57}$ Aesthetically, the City Beautiful was dominated by the classically inspired Beaux-Arts style, which was brought to North America by architectural students studying at the Paris École des beaux-arts. The 1893 Chicago World's Fair, overseen by City Beautiful pioneer Daniel Burnham (1846-1912), was imbued with this style (Fig. 3). ${ }^{58}$ In 1901 and 1902 Burnham was commissioned to redesign the core of Washington in the grand manner, for which he drew on European examples. ${ }^{59}$ Burnham later completed a City Beautiful plan for Chicago (1909), which "symbolized the maturation of the City Beautiful," and concentrated on the downtown and lakeshore regions of the city. ${ }^{60}$ 
The innovative 'White City' featured at the Chicago Fair thus inspired the next two decades of beautification in North America (approximately 1893 to 1914), as it embodied the ideals and style of the City Beautiful movement. This was particularly true of the sculptural adornment featured at the Fair, which featured contributions by Chicago-based neo-classical sculptor Lorado Taft (1860-1936). Taft created a pair of allegorical relief figures that flanked the entranceway to the Horticultural Building, as well as a frieze of children on the exterior of the structure and a set of female statues entitled Sleep of Flowers and Awakening of Flowers (Fig. 4). Beyond these, Taft's contribution consisted of enlarging maquettes into full-sized sculptures that were scattered around the Exposition. ${ }^{61}$

Following the 1893 Exposition and throughout the rest of his career, Taft was always chiefly concerned with the beauty of Chicago: he was of the opinion that "a city's beauty ... in the end proved profitable." ${ }^{62}$ Taft also reasoned that public sculpture was tantamount to a cultural record; it acted as one of the most important media in beautification. This aspiration would be realized in his sculptural group Fountain of the Great Lakes (1913), which was "heralded as both a wonderful object of great beauty and as a valuable example for a changing Chicago" (Fig. 5). ${ }^{63}$ The allegorical fountain featuring five female figures was installed outside the Art Institute of Chicago, and is significant because of the recognition it garnered for civic beautification in Chicago: "Like no other public sculpture in the city ... this fountain captured the attention and imagination of a public for whom it represented the qualities and ideals believed important in such works." 64 
Through the creation of monumental sculpture, Taft inexorably became connected to the progressive ideology of the City Beautiful. Indeed, Taft's sculptural endeavours reified the opinion of his contemporary Charles Mulford Robinson in the pursuit of civic beautification:

There is a sociological value in the larger happiness of great masses of people, whose only fields are park meadows, whose only walks are city streets, whose statues stand in public places, whose paintings hang where all may see, whose books and curios, whose drives and music, are first the city's where they live. The happier people of the rising City Beautiful will grow in love for it, in pride in it. They will be better citizens, because better instructed, more artistic, and filled with civic pride. ${ }^{65}$

Following the paradigm of turn-of-the-century American beautification schemes, Canadian cities soon commissioned City Beautiful designs by prominent city planners such as Thomas Mawson's Calgary plan of 1913 and Noulan Cauchon's (1872-1935) development reports for Hamilton from 1917 and 1919. Smaller City Beautiful proposals appeared in Edmonton, Regina, Winnipeg, London, and Windsor by $1920 .^{66}$ Indeed, an important Canadian City Beautiful proposal was the 1915 plan for Ottawa by Edward Bennett (1874-1954), who was involved in drawing up the 1909 Plan for Chicago. Bennett's design constitutes one of Canada's first comprehensive plans (Fig. 6), and although it was never fully constructed some of its technical recommendations were implemented in Ottawa nearly forty years later. ${ }^{67}$ As one of the preeminent City Beautiful planners, Bennett's design for Ottawa included the provision that the city should "create and foster in the minds of all citizens the sense of entity of the city and the interdependent relationship of the various elements of the city, and thereby ... promote a spirit of cooperation. $"$ "68 
The proposal for Ottawa thus followed the model of comprehensive

planning espoused by the City Beautiful, and - in keeping with the broad parameters of civic art applied in this thesis - included provisions for both aesthetic and utilitarian concerns:

Essential to its aesthetic considerations was a central core made up of the existing federal government buildings and a municipal presence through a city hall. The 'practical' aspects were a rationalization of the railway system and a central station; improved traffic circulation through street widening ... [and] the continuation of an improvement programme for parks and a parkway system. ${ }^{69}$

However, the project was ultimately abandoned as a result of the First World War and heavy criticism from City Beautiful detractors such as town planner Thomas Adams (1871-1940). An enthusiast of the more modest Garden City approach, ${ }^{70}$ he designed the town of Témiscaming in Quebec (formerly Kipawa) in $1917 .^{71}$ In 1936, Adams did, however, agree that the primary concern of city planning should be unity:

There is need of christening the art of city planning. The name 'civic design' should be chosen so as to distinguish it from the act or machinery of making plans. To be an art, city planning must be creative design, directed by intelligence, and applied to the forms and masses of buildings and the spaces about them. It must recognize the essential unity between buildings and landscapes, between forms and use of buildings, and between architectural and engineering elements in structures. ${ }^{72}$

After World War One beautification in general suffered from a paucity of public support as Canadians lost enthusiasm for grandiose planning movements. However, despite inadequate enthusiasm for the City Beautiful after 1914, it was especially expedient to apply a grandiose design to Ottawa: "Ugliness does matter, particularly in a national capital as dreary as Ottawa in 1913. Few patriotic citizens want an ugly capital. 
Federal politicians and civil servants ... wanted a well planned city for both symbolic and practical reasons. ${ }^{, 73}$

Aside from the provision that city planning should be comprehensive, a second fundamental ideal of the City Beautiful was the conceptualization of the city as a living organism. This idea was employed by beautification critics not only to promote a practicality-based approach to town planning, but also to "explain the possibility of curing or fixing it." ${ }^{74}$ This ideology corresponded with City Beautiful beliefs because it accounted for the entirety of a living organism (or a thriving city), whose components are interdependent. $^{75}$

In 1926 sociologist C.A. Dawson presented a city-planning lecture at McGill University entitled "The City as an Organism," in which he reiterated City Beautiful sentiments from the beginning of the century. In connecting the ideas that city planning should be as comprehensive as possible and that the city should be treated as a living organism, Dawson characterized the exponential expansion of modern cities as "growing pains ... [that] have become chronic," conditions for which many believed there was no remedy. ${ }^{76}$ Dawson stated that to typify the city as an organism was to concede that it has inherent unity. ${ }^{77} \mathrm{He}$ based this hypothesis on a diagram of concentric circles illustrating zones that fan outward from the centre (Fig. 7). While also accounting for geographical factors that affect the shape of the zones, such as rivers or mountains, Dawson argued: "The city grows as a whole. Its areas develop in relation to each other, become adjusted to each other and tend to form a structural unity. ${ }^{, 78}$ He thus posited that to plan a city in a piecemeal fashion was ineffectual, as the zones are interdependent. ${ }^{79}$ Therefore, much as the components of an organism are necessarily interconnected to ensure survival, the 
modern city must be conceptualized in this fashion to guarantee "stable, healthy and wholesome" growth. ${ }^{80}$

This theory was employed to curb the exponential development of Calgary, which Thomas Mawson presented through a City Beautiful scheme of 1914 (Fig. 8). Although Mawson's plan was eventually rejected because of its grandeur and immense cost, ${ }^{81}$ it illustrates the dissemination of City Beautiful ideology to Western Canada. Positing Calgary as the planning epicentre of the West, Mawson endeavoured to ameliorate its haphazard and unsystematic growth through regulated improvement:

Never before has there been such a phenomenal development and such rapid peopling of the hitherto waste places of the earth under the conditions provided and imposed by modern civilization, as in the great West of Canada at the present time. Not only is this so, but Calgary stands right at the centre of this development. It is the key-note of the situation. ${ }^{82}$

Mawson's intention was "to show the enormous importance of city planning from the financial, industrial, commercial and aesthetic standpoints, and in particular to draw attention to Calgary's unique opportunity for logical planning and for the creation of those amenities whether of park, boulevard, or recreation grounds." ${ }^{.83}$ Mawson's attempt to cure the ailments of the industrialized city through quintessential City Beautiful solutions such as systematic redevelopment and the incorporation of beauty was, as this section has documented, aligned with the progressive bent of the City Beautiful, which simultaneously sought to perfect the city and to profit from industrialization.

\section{The Social Gospel and Progressivism}

In addition to the provision of reformed cities, the City Beautiful was outfitted with a moral undertone that was tied to ethical behaviour. City Beautiful activists 
believed that beautified cities would inspire moral behaviour that could counteract threats to social and religious stability: "The goal [of the City Beautiful] beyond the tangibles was to influence the heart, mind, and purse of the citizen." ${ }^{, 4}$ Charles Mulford Robinson was one of the first to explicitly describe this aspect of City Beautiful reform: "The provision of this [civic] ideal, the setting before all the people of a tangible vision of their own possible city beautiful, will have other value than merely that of popular education. It will offer them inspiration. Nor will this inspiration be material only, but as clearly moral and political and intellectual." ${ }^{85}$ This ethical aspect of the City Beautiful elucidated why the phenomenon attempted to encompass entire cities. Indeed, as one scholar notes: "[The] development of [a] community consciousness which refused to accept perfection in occasional buildings and squalor in between ... seemed to assume that an ugly environment did psychological damage to all who beheld it, and that therefore to beautify the city as a whole was socially beneficial. ${ }^{186}$

Among the moral and ethical reformist movements to be appended to the City Beautiful was the theologically informed Social Gospel movement, which first arose in the late nineteenth century. It was "the type of Christianity that is deeply conscious of the relevance of its message to the life of society and that opposes the exclusion of any sphere of life from its direct influence. $" 87$ The Social Gospel appeared alongside many other international reform efforts in a period when religious convictions were seemingly threatened by secular industrial growth. ${ }^{88}$

Apart from its theoretical underpinnings, the Social Gospel movement emulated the City Beautiful as it was concerned with reforming the whole of society and as it contended with profound changes in modern civilization. As such the movement aimed 
beyond the strictly religious confines of any church and began to incorporate social factors. ${ }^{89}$ For example, in 1900 Social Gospel leader Josiah Strong (1847-1916) noted religion's need for community. He wrote: "[Religious activities] are now beginning to be directed to the uplifting of the whole man instead of a fraction of him, and to the salvation of society as well as to that of the individual. ${ }^{, 90}$ Thus, despite the assumptions of many to the contrary, the Social Gospel was not antagonistic to progress, ${ }^{91}$ but instead interacted with the changing "realities and problems of an increasingly industrialized and urbanized nation ... as a crusade for justice and righteousness in all areas of the common life." Indeed, Charles Mulford Robinson's 1903 reference to a "civic renaissance" promoted an "urban ideal - a clean, beautiful, well-governed city - [which would] eventually achieve a heaven on earth, secular in form though imbued with Christian principles." "94 Expressions such as Robinson's "civic renaissance" demarcated the ambition of progressives who "wished to tame the apparently disorganized, wildly growing city and to establish or restore a sense of community - that is, feelings of civic responsibility, or commitment to a common purpose, and of municipal patriotism. ${ }^{.95}$

In fact Progressivism in general - exemplified but not monopolized by the Social Gospel movement - has been broadly characterized as "the way in which a whole generation of Americans defined themselves politically and responded to the nation's problems at the turn of the century ... [including] the first comprehensive efforts to grapple with the ills of a modern urban-industrial society. ${ }^{.96}$ Although diverse in terms of concerns and social backgrounds, progressives generally construed advancement as a beneficial motivating force in society by responding optimistically to change and by embracing modernity, "hailing the civic art made possible through modern engineering, 
the affluence borne of modern commercial and industrial enterprise, and the advent of transit systems. ${ }^{, 97}$ Thus, although Progressivism of all types emerged alongside a surge of religion-based reform movements at the end of the nineteenth century, it was decidedly more optimistic than the other movements were. Rather than characterizing progress as a hindrance to traditional social and religious values, "the progressives exuded hope, optimism, and a conviction of their own rightness, ${ }^{, 98}$ in their goals of restructuring debasing social and living circumstances and of engendering social stability. ${ }^{99}$ Indeed, “the progressives' ameliorative reforms ... reflected their faith in progress - in mankind's ability, through purposeful action, to improve the environment and the conditions of life." 100

One outcome of progressive reform was the modernization of North American art and architecture. Much like the City Beautiful movement, Aesthetic Progressivism lauded the benefits of visually pleasing surroundings, while simultaneously providing an opportunity for Canadian artists to embrace the artistic innovations engendered by progress. In this way progressives discerned the potential for localized artistic innovation as an inherent aspect of modern progress. Charles Mulford Robinson sanctioned Aesthetic Progressivism when he noted in Modern Civic Art, "Thus the modern, dawning, civic art appears as the latest step in the course of civic evolution. The flowering of great cities into beauty is the sure and ultimate phase of a progressive development." ${ }^{101}$ Indeed, the publication of Modern Civic Art coincided with a proliferation of progressive civic improvement societies in North America, ${ }^{102}$ one of which was the Toronto Guild of Civic Art. 
The Toronto Guild of Civic Art

A prototypical civic improvement society from the turn of the twentieth century, the Toronto Guild of Civic Art (TGCA) was founded in 1897. Artist and TGCA member George Agnew Reid (1860-1947) listed the first functions of the Guild in 1898:

Among the many cities making efforts to attain to a high ideal of civic adornment, Toronto has taken her first step, and an organization is at work in our midst helping all worthy efforts to improve municipal art and which is alert to seize any opportunities that offer themselves where a body of art loving citizens, artists and architects can initiate projects intended to beautify the city. ${ }^{103}$

The original members of the TGCA (including banker and philanthropist Edmund Walker and architect W.A. Langton) sought to align Canadian urban planning with British reform, most notably the Arts and Crafts movement of William Morris. ${ }^{104}$ However, the TGCA is also credited with instigating the first City Beautiful projects in Toronto, ${ }^{105}$ including both a plan for systematic, regulated urban growth and a program of urban artistic decoration. The structure of the Guild was derived principally from that of the New York Municipal Art Society, ${ }^{106}$ whose motto was cited by Robinson in 1903 : "To make us love our city we must make our city lovely." "107 Importantly, the TGCA's membership united artists and laymen. Its founding mission was to advise on the presentation of fine art and architecture in Toronto: ${ }^{108}$

It is the purpose of the Guild to act as a purely supervising, consulting and advisory body to promote and encourage civic art, including mural painting and decoration, sculptures, fountains and other structures or works of art or of an artistic character; and to arrange for the execution of works of art by competent artists, to be chosen by competition or otherwise; and to hold exhibitions from time to time of works of art more especially connected with mural decoration, architectural and stained glass designs, sculpture and kindred subjects; and for the said purpose to appoint an advisory board to carry out the objects of the Guild, with powers to be declared by by-law, provided that in all matters the services 
of the advisory board shall be without remuneration; under the name of 'The Toronto Guild of Civic Art' ${ }^{109}$

University of Toronto professor and TGCA founder-member James Mavor (18541925) published an article on the association shortly after its inception. His discussion included the objectives of the Guild and a simplified version of the TGCA constitution. He summarized: "[The TGCA's] two chief purposes are, first, to promote and encourage the production of works of art intended for the embellishment of the city or for its public buildings; and, second, to provide an organization for a discriminating selection of these." ${ }^{\prime 10}$ Mavor characterized mural painting as the epitome of unified civic art:

Mural painting is not to be looked upon as a mere embellishment of a building; but ought rather to be regarded as an integral part of it, designed as a portion of its architectural detail and as necessary as any other portion to make the building a unity. This, of course, is another way of saying that art is not mere addition to life, but a part of it, and that the intelligent cultivation of it is as necessary as the intelligent cultivation of any other function of individual or social well-being. ${ }^{111}$

The TGCA's involvement in mural decoration will be explored at greater length in Chapter Two. For now it is sufficient to note that by referring to the 1890 s renaissance in mural decoration in the United States, Mavor called attention to the potential of civic art to merge art and life: an essential act of modern life. In the same way, the arts must be integrated into urban planning to achieve the best possible expression of the Canadian city. Elsewhere, an article in Canadian Architect and Builder called for the integration of architects with the TGCA. ${ }^{112}$ Although the author of this particular text is unknown, the stated purpose was the same: to create the finest expression of a modern city by uniting the arts as a comprehensive whole. 
Robinson's philosophy of civic art was further sustained in the TGCA's 1909 beautification plan for Toronto, which became the Guild's focus after the completion of the mural campaign in the city (Fig. 9). The proposal by W.A. Langton suggested that permitting Toronto to develop without a comprehensive plan would not be in the public's best interests, ${ }^{113}$ and therefore two courses of action should be taken. The first strategy accentuated diagonal roads incised through the grid plan of the streets, creating irregular vistas: "Here, in the junctions of diagonal roads with the old rectangular system, is the natural occasion for many features of the kind, introducing beauty into the street plan of the city. Of other features it may be said that they add beauty to Toronto; but of these, that they will make Toronto beautiful." 114 The use of diagonal roads was an archetypal City Beautiful motif, ${ }^{115}$ although it was rarely put into practice.

The TGCA's second proposal for the comprehensive plan of Toronto was the creation of a network of parks in the city. Whereas diagonal roads would add beauty to Toronto, a parkway would give the city its personality: "If the diagonal roads will make a city of Toronto ... the parks are the feature of the plan which most bring out the character given to the city by its site," 116 as Langton noted in 1909:

We have kept in view as far as possible, in drawing this plan, the characteristic features of the place, and have endeavoured to incorporate them in the plan, so as to preserve and indeed develop them, and thus to develop the natural character we have and make of Toronto not just a beautiful city, beautiful in a conventional way, after the model of some other city, but to bring out its own beauty. ${ }^{117}$

The proposed creation of a park network throughout Toronto was in accordance with Frederick Law Olmsted's design of a landscaped parkway connecting green spaces in Buffalo (1868-1898). ${ }^{118}$ Furthermore, the TGCA's plan corroborated the Olmstedian 
philosophy that nature ameliorates the tribulations of modern society. Although the parkway was never implemented, the TGCA's city planning guidelines sought "remedies for the evils of congestion of population in cities," 119 as well as:

To provide for wide continuous business thoroughfares, parks, parkways, playgrounds, aquatic sports, pure water, sanitary sewage disposal, rapid transit, clean streets, underground wires, curtailment of sign and noise nuisances, building laws for structural, sanitary and fire safety and tenement laws to restrict the congestion of population. ${ }^{120}$

The breadth of the concerns mentioned in the TGCA's recommendations for town planning demonstrates the holistic focus of the civic art movement in Canada at the turn of the century.

The TGCA is but a single example of the civic improvement societies that proliferated across North America. ${ }^{121}$ However, the interconnections between the Guild, Robinson's views on civic art as a broad movement, and Olmsted's philosophy of nature and landscape design illustrate the philosophical grounding of groups such as the TGCA at the beginning of the twentieth century.

\section{The City Scientific: Efficacious Planning}

The City Beautiful movement was phased out in about 1914, largely for financial reasons that were exacerbated by the start of the First World War. The decline of the City Beautiful ideal was paralleled by the rise of the City Scientific. The City Scientific movement rejected the aesthetic tenets of the City Beautiful, yet its practitioners often reiterated the importance of beauty in the urban setting.

Despite the perceptible influence of the City Beautiful movement throughout the first decade of the twentieth century, the phenomenon acquired a social stigma that 
prevented holistic promotion or application for the next two decades. As the term 'city planning' became increasingly associated with grand City Beautiful schemes, and as the latter tended to overlook societal concerns in favour of large civic centres, the entire planning movement began to be seen as an "artistic fad." ${ }^{\prime 22}$ The City Beautiful ultimately acquired a reputation for grandiose design schemes, a lack of empathy for the urban poor, and expensive (often unfeasible) endeavours such as monumental civic renovations. A development often cited in connection with the demise of the City Beautiful was the city of Maisonneuve, which was built east of Montreal from 1910 to 1915. The sheer cost of creating an entirely new city (instead of remodeling an existing space) eventually bankrupted the project, ${ }^{123}$ yet Maisonneuve should not be disregarded. The four-structure civic centre and surrounding housing units constitute one of the very rare examples of a Canadian City Beautiful scheme that was actually carried through to fruition. ${ }^{124}$

Following the loss of interest in aesthetically grandiose City Beautiful plans, an early allusion to the City Scientific appeared in a lecture at the Fifth National Conference on City Planning in Chicago (1913) by architect George B. Ford. He astutely outlined the unique characteristics of the City Scientific and the City Beautiful, and stressed their independent status: "The problems of convenience, of health, and of efficiency are matters of science, while the things which foster our own delight in the city and which impress the stranger within our gates come within the range of the aesthetic." ${ }^{25}$ Ford credited aesthetics with enhancing the public's esteem for reform. In turn, this enthusiasm could be utilized to develop infrastructure: the scientific aspect of city planning. ${ }^{126}$ Furthermore, many advocates of the City Scientific maintained that some of the aesthetic 
principles of the City Beautiful, namely symmetry and order, would be the natural product of effective utilitarian planning. ${ }^{127}$

Ford's presentation argued that as of 1913 North American society should acquire a proper appreciation for its essential needs: "We have now got our perspective and a sense of the proportion of things, and we know that considerations of health, convenience and efficiency are of fundamental importance [to the city]." 28 Ford's position was substantiated in 1915 when City Scientific advocates were adamant that the practical approach to city planning should be implemented over the purely aesthetic approach. This motivation was largely due not only to the high costs associated with the more spectacular City Beautiful plans, but also to exponential population growth in Canada between 1910 and 1914, and the resulting housing crisis for families (the working class in particular). ${ }^{129}$

One of the primary enthusiasts of city planning in Canada was town planner Noulan Cauchon. Cauchon's early theories were heavily influenced by those of Robinson and of Raymond Unwin. ${ }^{130}$ However, after he completed a 1917 survey for the city of Hamilton, Cauchon terminated his affiliation with the City Beautiful and turned his attention to scientific planning. ${ }^{131}$ The definition of the City Scientific by which Cauchon adhered was that reproduced in the constitution of the Town Planning Institute of Canada (TPIC): "The scientific and orderly disposition of land and buildings in use and development with a view to obviating congestion and securing economic and social efficiency, health and well being in urban and rural communities." ${ }^{32}$ Cauchon's practicality-based planning ideology concentrated primarily on city efficiency, through "impressive city-wide infrastructure systems for fresh water, sewerage, electricity, gas, 
paved streets, railways and electric streetcars," as well as accommodations for the proliferation of automobile usage in North America. ${ }^{133}$

The TPIC was faithful to the Garden City approach favoured by British planner Thomas Adams, whose focus had shifted to suburban planning by the end of the First World War. ${ }^{134}$ Adams applied his extensive knowledge of British suburban planning to Canada, ${ }^{135}$ which was evident at the Cleveland Eighth National Conference on City Planning (1916) where he led a discussion entitled "The Beginnings of Town Planning in Canada." Adams spoke of the venture to establish a town planning committee in this country: a venture which was incorporated as the TPIC in 1919. He outlined three main concerns for civic improvement: municipal government, town planning and housing, and public health. ${ }^{136}$ His lecture coincided with the popular growth of the City Scientific as it advocated "the need for scientific knowledge relating to town planning." 137 Particularly during times of war, government factions including provincial and municipal groups favoured suburban regulations contending with a mounting housing crisis. Practical plans were implemented over beautification projects, such as Toronto's plans for a new sewer system. ${ }^{138}$ Sculptors Frances Loring (1887-1968) and Florence Wyle (1881-1968) described an instance in which their sculptural adornment projects were "sneaked in sort of as construction work [for fear that] the opposition should realize that art is being indulged in during war times."139 Thus, despite the friendliness of most City Scientific thinkers regarding the importance of the arts, a divide could appear between urban reform that was perceived to be useful, and artistic embellishments that were considered superfluous in times of social and economic crisis. 
However, as noted above, there was never any question of emphasizing the City Scientific at the total expense of the City Beautiful. For example, Noulan Cauchon's town planning theories demonstrated that despite the value of scientific planning in the city, aesthetics could not be completely obliterated. This was demonstrated through his 1917 plan for Hamilton, which incorporated both aesthetic and scientific considerations, ${ }^{140}$ and through his publications and lectures (see Chapter Three). In his 1926 essay on the subject of town planning, Cauchon wrote of a tripartite system of survival for the modern Canadian city, comprising ethics, economics and art. ${ }^{141}$ Although he maintained that art should be subsidiary to economics and ethics, ${ }^{142}$ the presence of the arts in his discussion signals his recognition of their pivotal role in the convalescence of the modern Canadian city. Furthermore, small-scale improvements made to cities as a result of City Beautiful planning proved that utility could be joined to beauty. These included "putting utility wires underground ... improving street furniture, restricting signage, and the extraordinary expansion of park, parkway and boulevard systems." ${ }^{143}$

Thus, for Charles Mulford Robinson and other advocates including Noulan Cauchon, civic art was able to surmount this divide between the scientific and the aesthetic. As Robinson maintained throughout his publications, civic art was only successful when beauty was integrated with utility ${ }^{144}$ He further wrote of architects being involved in the expansion of civic art: "[They] make beauty, now of form and now of color [sic], as important as utility." ${ }^{\text {"145 }}$ Indeed, despite his adherence to the City Scientific, George B. Ford began his 1913 lecture with the following disclaimer:

Let me sound a note of warning, since in certain cities science in city planning has been decidedly overdone. The reaction from the 'city beautiful' has swung the pendulum too far the other way, and the work has 
been put entirely in the charge of engineers who, while they have achieved excellent results from a scientific standpoint, have failed to appreciate the vital importance of the social and aesthetic sides of the problem. In doing so they have attained results fully as unfortunate in their way as have those city planners who have approached the subject from only the standpoint of the city beautiful. ${ }^{146}$

The phenomenon of comprehensive planning appeared when grandiose city plans fell from popular favour by the end of the First World War. This movement appeared in the late $1920 \mathrm{~s}$, as evidenced by a second wave of improvement plans. For example, Vancouver had previously implemented small scale improvements such as planted trees ${ }^{147}$ but a beautification and improvement plan of 1930 by the Vancouver Town Planning Commission proposed a grand civic centre set at the crest of a new monumental axis (Fig. 10). ${ }^{148}$ In turn, from 1935 to 1941 Niagara Falls acquired an open-air amphitheatre and garden (the Oakes Garden Theatre), a triumphal arch, a parkway along the border, and the Rainbow Bridge and Gardens connecting Canada to the United States (Figs. 11-13). ${ }^{149}$

The comprehensive city planning movement was invariably shaped by each approach of the city planning movement, including the City Beautiful, the Social Gospel and Progressivism, and the City Scientific. The result, as documented in Chapter One, was a hybrid form of Canadian city planning which necessitated the amalgamation of beauty and utility also exemplified through civic art. 


\section{Endnotes to Chapter One}

' Robinson, Modern Clvic Art, or, the City Made Beautıful, 24

${ }^{2}$ Nicholas Terpstra, "Local Polıtıcs and Local Plannıng A Case Study of Hamılton, Ontarıo, 1915-1930," Urban History Review 14, no 2 (Oct 1985) 116

${ }^{3}$ Ibsd , 115-116

${ }^{4}$ Charles C Bohl, "Civic Art Then and Now The Culture of Good Place-makıng," in Sitte, Hegemann and the Metropolts Modern Clvic Art and International Exchanges, ed Charles C Bohl and Jean-François Lejeune (London Routledge, 2009), 9

${ }^{5}$ Gilbert Stelter, "Rethınkıng the Significance of the City Beautıful Ided," in Urban Plannıng in a Changing World, The Twentieth Century Experience, ed Robert Freestone (London E \& FN Spon, 2000) 112

${ }^{6}$ Mawson, Civic Art Studies in Town Planning, Parks, Boulevards and Open Spaces, 2

${ }^{7}$ Geoffrey Simmıns, "Improving the City - Thomas Mawson," in Documents in Canadian Architecture, ed Geoffrey Simmins (Peterborough Broadview Press, 1992), 77

${ }^{8}$ Raymond Unwın quoted at Bohl, 13

${ }^{9}$ Stelter, 98

${ }^{10} \mathrm{G}$ Trafford Hewitt, "Canada and the United States as a Field for the Garden City Movement," in Proceedings of the Sixth Natıonal Conference on City Planning, Toronto, May 25 27, 1914 (Cambridge The University Press, 1914) 184-185

"Ib1d, 180

${ }^{12}$ Ibıd , 188

${ }^{13}$ Stelter, 98

${ }^{14}$ Robinson, Modern Civic Art, or, the City Made Beautıful, 28

${ }^{15}$ Ibid , 29

${ }^{16}$ Ibid , 30

${ }^{17}$ J P Hynes, "Hıstorıc," in Report on a Comprehensive Plan for Systematıc Civic Improvements in Toronto (Toronto Toronto Guild of Civic Art, 1909) 4

${ }^{18}$ George L Scheper, "The Reformist Visıon of Frederıck Law Olmsted and the Poetics of Park Design," The New England Quarterly 62 no 3 (Sept , 1989) 371

${ }^{19}$ Ibid , 371

${ }^{20}$ Ibid , 372

'Frederıck Law Olmsted, 1863 Reproduced from Olmsted's notebook in Irving D Fisher, Frederick Law Olmsted and the City Planning Movernent in the Unted States (Ann Arbor UMI Research Press, 1986), 29 
${ }^{22} \mathrm{Ib}$ id , 30

${ }^{23} \mathrm{Ib} 1 \mathrm{~d}, 77$

${ }^{24}$ This quote by Olmsted was reproduced in Fisher, 29

${ }^{25} \mathrm{Ib}, \mathrm{d}, 30$

${ }^{26}$ Peter Lawrence Kredl, "The Origın and Development of Mount Royal Park, Montreal, 18741900 Ideal vs Reality" (M A Thesis, York University, 1983) 86-87

${ }^{27}$ A L Murray, "Frederıck Law Olmsted and the Design of Mount Royal Park, Montreal," Journal of the Society of Architectural Historians 26 no 3 (Oct, 1967) 163

${ }^{28}$ Kredl, 74

${ }^{29}$ Ib1d , 79

${ }^{30}$ Murray, 165

${ }^{31}$ Kredl, 80

${ }^{32}$ Murray, 166

${ }^{33}$ Ibid , 166167

${ }^{34}$ Janıce Selıne, "Frederıck Law Olmsted's Mount Royal Park, Montreal Desıgn and Context" (M A Thesis, Concordia University, 1983) 53

${ }^{35}$ Murray, 167

${ }^{\circ 6}$ Seline, 53

${ }^{37}$ Fisher, 29

${ }^{38}$ Selıne, 53

${ }^{39}$ Kredl, 87

40 Nancy Pollock Ellwand, "Rıckson Outhet Bringing the Olmsted Legacy to Canada A Romantıc Vıew of Nature in the Metropolıs and the Hinterland," Journal of Canadıan Studies 44 no 1 (Winter 2010) 171 Pollock Ellwand notes that the Olmsted firm (consistıng of Olmsted $\mathrm{Sr}$, his son Frederick Law Olmsted Jr , and his stepson John Charles Olmsted) was involved in around 100 Canadian projects, although two-thirds were never completed The majority of these projects were commissioned by wealthy individuals who wanted to aggrandize their private estates The commissions appeared across Canada, but most took place in Britısh Columbia and Ontario However, of the public city improvement commissions, notable examples include the Toronto Water Front $(1902,1912)$, the Winnıpeg City Plan (n d ), a design requested by the Calgary Alberta City Plannıng Commıssion (1912), and the Ottawa City Plan (1913-1914) See Nancy Pollock Ellwand, "The Omlsted Furm in Canada," in The Master List of Design Projects of the Olmsted Firm, eds Lucy Lawlıss, Carolıne Loughlın and Lauren Meıer (Washington National Association for Olmsted Parks, 2008), 15-18, as well as the "City and Regional Planning and Improvement Projects" list from the same text (85-93) 
${ }^{41}$ Pollock-Ellwand, "Rıckson Outhet," 142

${ }^{42}$ Ibıd , 140

${ }^{43}$ Ibid , 141 Pollock-Ellwand lists examples of the private housing projects completed in Canada In additıon to examples in Britısh Columbia and New Brunswick, the author records work at Casa Loma in Toronto and to houses in Montreal's Square Mile region (173)

${ }^{44}$ Willam H Wilson, The City Beautıful Movement (Baltımore Johns Hopkins Unıversity Press, 1989), 9

${ }^{45}$ Ibid , 10

${ }^{46}$ Walter Van Nus, "The Fate of City Beautıful Thought in Canada, 1893-1930," Hustorical Papers 10 no 1 (1975) 206

${ }^{47}$ Ibıd , 194

${ }^{48}$ Stelter, 99

${ }^{49}$ Van Nus, 191

${ }^{50}$ Werner Hegemann and Elbert Peets, The American Vitruvius An Architect's Handbook of Civic Art 1922, Reprint, ed Alan J Plattus (New York Princeton Architectural Press, 1988) 1

${ }^{51}$ Stelter, 98

${ }^{52}$ Ibid , 99

${ }^{53}$ Ib1d , 100

${ }^{54}$ Ibid , 110

s5 Ibid, 101

${ }^{56}$ Van Nus, 191

${ }^{57}$ Charles Mulford Robinson, The Improvement of Towns and Citles, or, the Practical Basts of Civic Aesthetıcs, 1901 (Reprint, New York Putnam and Sons, 1913), 192

${ }^{\varsigma 8}$ Stelter, 102

${ }^{59}$ Ibid , 102103

${ }^{60}$ Wilson, 281

${ }^{61}$ Timothy $\mathbf{J}$ Garvey, Public Sculptor Lorado Taft and the Beautification of Chicago (Chıcago Unıversity of Illinos Press, 1988), 43

(b) Ibrd , 24

${ }^{63}$ Ibrd , 3 
${ }^{64}$ Ib1d , 3

${ }^{65}$ Charles Mulford Robinson, "Improvement in City Life III Aesthetıc Progress," Atlantıc Monthly 83 (June, 1899), 771-785, quoted at Garvey, 33

${ }^{66}$ Stelter, 111

${ }^{67}$ David Gordon, "A City Beautıful Plan for Canada's Capıtal Edward Bennett and the 1915 plan for Ottawa and Hull," Planning Perspectives 13 (1998) 275

${ }^{68}$ Edward Bennett quoted at Gordon, "A City Beautıful Plan for Canada's Capıtal," 281

${ }^{69}$ Stelter, 112

${ }^{70}$ Ib1d , 109-1 10

${ }^{71}$ Ib1d , 113-114

${ }^{72}$ Thomas Adams, Outline of Town and City Planning, A Review of Past Efforts and Modern Aims (New York Russel Sage Foundation, 1936) 23

${ }^{73}$ Gordon, “A City Beautıful Plan for Canada's Capital,” 293

${ }^{74}$ Stelter, 110

${ }^{75}$ Ibid , 110

${ }^{76}$ C A Dawson, "The City as an Organism," in Saving the Canadian City The First Phase 1880-1920, An Anthology of Early Articles on Urban Reform, ed Paul Rutherford (Toronto U of T Press, 1974) 276

${ }^{77}$ Ibid , 276

${ }^{78}$ Ibid , 280

${ }^{79}$ Ibid , 281

${ }^{80}$ Ib1d , 282

${ }^{81}$ Van Nus, 203

${ }^{82}$ Simmins, "Improving the City - Thomas Mawson," 83

${ }^{83}$ Ibıd , 86

${ }^{84}$ Wilson, 1

${ }^{85}$ Robınson, Modern Civic Art, or, the City Made Beautiful, 35

${ }^{86}$ Van Nus, 193

${ }^{87}$ Willem A Visser'T Hooft, The Background of the Social Gospel in America, 1928 (Reprint, St Louss The Bethany Press, 1963), 16 
${ }^{88}$ Donald K Gorrell, The Age of Social Responsibulity The Soctal Gospel in the Progressive Era, 1900 1910 (Macon Mercer University Press, 1988), 12

${ }^{89}$ Ronald C White and C Howard Hopkıns, The Socıal Gospel Religion and Reform in Changing America (Philadelphıa Temple Unıversity Press, 1976), xı

${ }^{90}$ Josiah Strong as quoted in Gorrell, 1112

${ }^{91}$ In The Age of Soctal Responsibulty The Social Gospel in the Progressive Era, 1900 1910, Gorrell explaıns how Christıanıty adapted to modernıty, notably through rejuvenated church architecture (12)

${ }^{92}$ White and Hopkins, xil

${ }^{93}$ Robinson, Modern Civic Art, or, the City Made Beautiful, 9

${ }^{94}$ Wilson, 41

${ }^{95}$ Wilson, 41

${ }^{96}$ Arthur S Link and Richard L McCormick, Progressivtsm (Arlıngton Heights Harlan Davidson, Inc, 1983) 3

${ }^{97}$ Bohl, 16

${ }^{98}$ Wilson, 41

${ }^{99}$ Link and McCormick, 2

${ }^{100}$ Ibid , 21

${ }^{101}$ Robinson, Modern Civic Art, or, the City Made Beautiful, 12

${ }^{102}$ Bohl, 8

${ }^{103}$ George A Reid, "Mural Decoration," CAB 11 no 1 (Jan 1898) 1314

${ }^{104}$ Rosalınd Pepall, "The Murals of George A Reıd in the Toronto Munıcıpal Buıldıngs, 1897-1899" (M A Thesis Concordia University, 1982), 1314

${ }^{105}$ Mark Osbaldeston, Unbult Toronto A History of the City that Might Have Been (Toronto Dundurn Press, 2008), 22

${ }^{106}$ Pepall, 22

${ }^{107}$ Robinson, Modein Civic Art, or , the City Made Beautiful, 35

${ }^{108}$ Pepall, 34-35

109 "The Toronto Guild of Civic Art," CAB 11 no 3 (Mar 1898) 51

${ }^{110}$ James Mavor, "Note on the Objects of the Toronto Guıld of Civic Art and on the Exhıbıtıon of Prints of Mural Paintıngs," CAB 11 no 5 (May 1898) 88

${ }^{11}$ Mavor, 88 
112 "Toronto Gu1ld of Civic Art," CAB 11 no 4 (Apr 1898) 77

${ }^{113}$ W A Langton, "A Plan for Toronto," in Report on a Comprehensive Plan for Systematıc Civic Improvements in Toronto (Toronto Toronto Guld of Civic Art, 1909) 10

${ }^{114}$ Ibid , 14

${ }^{115}$ Osbaldeston, 24

${ }^{116}$ Langton, 16

${ }^{117}$ Ibid, 17

${ }^{118}$ Osbaldeston, 24

${ }^{119}$ Hynes, 5

${ }^{120}$ Ibld , 5

${ }^{121}$ Perhaps the largest Canadian civic improvement association in the twentieth century was the Town Plannıng Instıtute of Canada (TPIC), Instigated in 1919 by Thomas Adams (1871-1940) and Noulan Cauchon (1872-1935) It was derived from global reform movements that manifested in Canada as town planning and civic beautification efforts Furthermore, this period witnessed a proliferation of professional associations, which in architecture were represented by the Ontano Association of Architects (1889) at the provincial level, and the Royal Architectural Institute of Canada (1907) at the national echelon

${ }^{122} \mathrm{Van}$ Nus, 205

${ }^{123}$ Stelter, 114

${ }^{124}$ Ibld , 111

${ }^{125}$ George B Ford, "The City Scientific," in Proceedings from the Fifth National Conference on Clty Planning, Chicago, May 5-7, 1913 (Cambridge The Unıversity Press, 1913), 32

${ }^{126}$ Ibıd , 3233

${ }^{127}$ Van Nus, 205

${ }^{128}$ Ford, 33

${ }^{129}$ Van Nus, $199-200$

${ }^{130}$ David L A Gordon, "Agitatıng People's Braıns' Noulan Cauchon and the City Scientific in Canada's Capital," Planning Perspectives 23 (July 2008) 353

${ }^{131}$ Ib1d , 355-356

${ }^{132}$ Constitution of the TPIC as reproduced in Gordon, "Noulan Cauchon and the City Scientific in Canada's Capital," 356

${ }^{13}$ Ib1d, 353 
${ }^{134}$ Stelter, 110

${ }^{135}$ Van Nus, 202

${ }^{136}$ Thomas Adams, "The Beginnıngs of Town Plannıng in Canada," in Proceedings from the Elghth National Conference on City Planning, Cleveland, June 5 7, 1916 (Cambridge The University Press, 1916) 224

${ }^{137}$ Ibrd , 228

${ }^{138}$ Ib1d , 203

${ }^{139}$ Letter from Frances Loring to H O McCurry, as reproduced in Chrıstıne Boyanoskı, Loring and Wyle, Sculptors' Legacy (Toronto Art Gallery of Ontario, 1987), 48-49

${ }^{140}$ Gordon, "Noulan Cauchon and the City Screntific in Canada's Capital," 355

${ }^{14 \mid}$ Noulan Cauchon, "Town Plannıng," JRAIC 3 no 4 (July-August 1926) 165

${ }^{142}$ Gordon, "Noulan Cauchon and the City Scientıfic in Canada's Capital," 355

${ }^{143}$ Stelter, 114

${ }^{144}$ Robinson, Modern Civic Art, or, the City Made Beautiful, 29

${ }^{145}$ Robinson, The Improvement of Towns and Cittes, or, the Practical Basts of Civic Aesthetics, 192

${ }^{146}$ Ford, 31-32

147 Stelter, 109

${ }^{148}$ Van Nus, 198

${ }^{149}$ Under the supervision of Thomas B McQuesten, the Niagara Parks Commission set out to beautıfy the Canadian side of the border with the United States These projects have been recounted at length in histories of Thomas McQuesten such as John Best's Thomas Baker McQuesten Public Works Politics and Imagination (1991) and Mary J Anderson's Tragedy and Trumph Ruby and Thomas Baher McQuesten (2011) The indıvidual projects at Niagara Falls are discussed in detall by Joan Coutu in "A Drive Through Canadian History People, Cars and Public Art at Niagara Falls in the 1930s" (2009), "Vehicles of Natıonalism Defining Canada in the 1930s" (2002) and her 1989 M A thesis, "Design and Patronage The Architecture of the Niagara Parks 1935-1941" 
Chapter Two - How Reform Can Come to the Arts: The Canadian Allied Arts

"The urge was, as it is yet, to get architects, engineers, surveyors, landscape architects, sculptors, sociologists, lawyers and others, to cultivate an overlap of knowledge, whilst each keeping to the exercise of his individual functions, the better in co-operation towards the end of human betterment." - Noulan Cauchon, 1926

The most prominent feature that characterized the comprehensive city planning movement was the concept of collaboration. In the instance of beautification projects, collaboration entailed that those loyal to the aesthetic (or beautiful), such as painters, architects, landscape architects and sculptors, worked cooperatively with devotees of the scientific (or utilitarian), such as engineers and town planners. Within the fine arts, collaborative work more specifically manifested itself in the allied arts concept, which became a large proponent of Canadian art and design in the twentieth century.

Sculptor Hamilton MacCarthy (1846-1939) provided one of the first explicit references to what would become known as the Canadian allied arts movement in an 1895 address to the Ontario Association of Architects. The lecture, entitled "The Aesthetic Unity of the Fine Arts," sketched a tripartite alliance:

In colour and texture added to form, we reach the absolute - the highest aesthetic ideal of beauty. This trinity in unity, of colour, texture, form (form including proportion), constitutes the essential and inseparable elements which the master builder has incorporated, and shows the relation and dependence of each upon the other, to express a perfect ensemble, each of the links being a sine qua non to the success of the whole. ${ }^{2}$

MacCarthy described three fundamental elements of unified art: colour, which in his estimation is equated with painting; texture, brought to life through sculpture; and form, embodied in architecture. MacCarthy demonstrated that the fine arts were united in a 
collaborative process akin to that of the city planning movement, which adopted a range of approaches to urban beautification and improvement.

True unified art required collaboration between the arts, as well as within each profession. In the early twentieth century a type of aesthetic bloc formed which fostered alliances within each of the arts through the establishment of Canadian professional associations (such as the Ontario Association of Architects, formed in 1889). Advocacy for aesthetic alliances was also evident through the work of individual artists (such as muralist George A. Reid), through innovative exhibitions (including the Biennial Exhibitions of Architecture and the Allied Arts in Toronto) and through new periodicals dedicated to fine art and architecture (including essays promoting unity). These efforts fostered and furthered the idea of collaboration between the arts of painting, sculpture, craft, architecture and landscape architecture. Combined with the collaborative aspects of city planning as discussed in Chapter One, this unity of the fine arts was integral to the phenomenon of civic art in its most comprehensive and ambitious sense.

\section{George A. Reid}

The maturation of the Canadian allied arts is inexorably connected to the public works and civic dedication of muralist and aesthete George Agnew Reid. Reid was instrumental in establishing a doctrine of civic art in Canada, particularly through selfinstigated mural projects, publications, and new professional arts associations. Reid was prominent in founding the Society of Mural Decorators (established 1894), the Toronto Guild of Civic Art (1897), and the Canadian Society of Applied Art (1901). It was primarily the efforts of artists such as Reid and associations such as the Toronto Guild of 
Civic Art that created the foundation for modern Canadian civic art, which flourished through fine art, architecture and civic beautification.

George Reid believed that art could articulate the nebulous culture of the young Canadian nation. He wrote: "It is often argued that ours is too young a country to expect much in the way of high art ... [a sense of it] must come through a genuine love for the perfect, the beautiful; and as the air, the soil, the climate of our country colour our blood and stamp our natures, our art must be native to be healthy." 3 His views were in symbiosis with those of architects, town planners, sculptors and other professionals of the period, who were confident that the collaborative efforts of city planning would express the best vision for the nation. For example, architect Frederick Ackerman reiterated Reid's philosophy at the Detroit National Conference on City Planning (1915): “Art is not so much an expression of a people's concept of beauty as it is a physical expression of their composite ideas, or in other words, their culture." Reid would repeatedly return to this concept as a basis for publicizing unified art in Canada. His devotion to civic beautification culminated with a mural program for the Municipal Buildings in Toronto. ${ }^{5}$

Reid posited a solution for "how reform can come to the arts," which necessitated "the reunion of the arts now so disassociated." Reid was committed to the academic training in which he had experience in Toronto (under Robert Harris), Philadelphia (with Thomas Eakins) and Europe (with Benjamin Constant at the Académie Julian). Yet he maintained that the academic tradition should be adaptable, so as to incorporate modern innovations in art and technology. ${ }^{7}$ Reid embraced the integration of modernism with traditional art forms, thus earning him the title "liberal-conservative." 
Reid partly derived the concept of uniting the arts from William Morris'

Arts and Crafts model.. The Arts and Crafts emphasis on "cohesiveness of vision" was apparent in Reid's genre painting and architectural designs, ${ }^{10}$ particularly in his work in Onteora, New York. There he designed a library, a church, and several summer homes in stone and wood with "a straightforward, solid approach to the division of space,"11 all in an Arts and Crafts spirit. Evidence of Reid's response to the Arts and Crafts movement is also clear in his detail-oriented furniture designs for Onteora residents. ${ }^{12}$

In 1925, Canadian critic Newton MacTavish (1875-1941) isolated Reid and his work in a chapter of The Fine Arts in Canada. This text recognized Reid's efforts to unite the arts and merge them with quotidian life. As MacTavish wrote, "[Reid] has declared his belief in art for life's sake as opposed to 'art for art's sake'."13 MacTavish also indicated that Reid had successfully blended utility with beauty:

Reid has been the outstanding champion of art and of the importance that artistic application imparts to many of our common, day-by-day activities ... he has striven to get an expression of art into our buildings, into our parks and highways, into our civic life, into manufactures, and indeed into many contrivances that we are only too prone to regard as being exclusively utilitarian. ${ }^{14}$

This passage correctly identifies the form of civic art by which Reid abided: a form in which art could be both utilitarian and beautiful. Alongside civic art and collaborative planning activists, Reid considered this the highest aspiration for Canadian art:

The discussion for and against utilitarianism has been a long one, and is yet far from settled; and perhaps until our thought is more logical and our use of language more careful, we shall continue to speak of beauty and use as being essentially different, and of aesthetics as having nothing to do with morals ... I take exception to the other [perspective] when it claims that art has nothing to do with morals and aesthetics, and press the claim that morals and aesthetics in the highest sense cannot be separated. ${ }^{15}$ 
Approximating Charles Mulford Robinson's assertion that "there can only be one successful civic art ... one which joins utility to beauty, ${ }^{\prime 16}$ George Reid asserted that art is a didactic tool. He believed that beauty could serve a utilitarian purpose, which was, justifiably, to educate. As Reid stated: "Such efforts are additional evidences of the revival of the art instinct among us, showing the realization that is felt of the necessity of surrounding our lives with all that is beautiful." ${ }^{\prime 17}$ This was art with an explicitly civic role.

The perceived threat of late nineteenth-century industrialism and early twentiethcentury modernism created opposition to Reid's fundamental belief in 'art for life's sake' amongst those who were only alert to utilitarian concerns. In reaction, he alleged that art could be used for edification. Reid alleged that art had a moral responsibility: "The painter believes that the aspiration towards the beautiful is essentially an ethical quality." ${ }^{18}$ This philosophy was aligned with the ideology of City Beautiful reform, notably the concept that morality and citizenship can be absorbed from one's surroundings as well as from a rationally ordered structure. Together with Reid, civic art advocates believed that indoor and outdoor areas beautified by the allied arts could perform the same function as the natural environment. Similarly, Reid believed that Canadian mural painting would benefit from the principles embodied in the city planning phenomenon. ${ }^{19}$

Reid's involvement with the Toronto Guild of Civic Art underlines the association's predisposition toward the application of mural decoration in civic spaces. As TGCA founder-member James Mavor wrote, "among the methods of embellishing public buildings by way, on the one hand, of expressing public magnificence, and on the 
other of stimulating the appreciation of art, mural painting has, during the past few years, taken perhaps the most prominent place. ${ }^{, 20}$ In addition to advocating mural decoration in public spaces, Mavor's essay reproduced a speech made by TGCA president Byron Edmund Walker at the opening of the Guild's exhibition of Copley Prints, so named after the photographer whose work comprised the exhibition. The exhibition opened in Toronto on 16 April, 1898, and presented examples of mural revivals from the United States. ${ }^{21}$ Much like Mavor, Walker reiterated the TGCA's penchant for mural art:

We shall hope that this exhibition will at least open the eyes of many Canadians to our short-comings. You are aware that a plan of decoration for the council chamber of the new city hall was placed before the council ... Mr. Reid has offered to execute two panels gratuitously, the work to be done under the supervision of the Guild of Civic Art. This generous missionary effort on the part of Mr. Reid should be watched most carefully by all who care about the development of art in our city. ${ }^{22}$

Although some assert that Reid never successfully merged utility with beauty, ${ }^{23}$ he continued to advocate in favour of the pairing throughout his career. Reid was also sympathetic to town planners and beautification activists who considered the 1893 World's Columbian Exposition the ideal prototype for collaborative planning between professionals. He referenced the event to delineate the "union of the arts" that resulted when architects, engineers, landscape gardeners, sculptors and painters collaborated on the design for the Exposition. ${ }^{24}$ Reid wrote on the subject of unity between the arts: "Indeed the formative arts are so nearly one that it is only for convenience we speak of painting, sculpture and design as separate from the general term 'architecture'; painting and sculpture would undoubtedly be homeless without the art of building, and architecture would be little more than mere building without decoration." ${ }^{25}$ The archetype 
of the unified, aesthetically pleasing city embodied in the 1893 Exposition (and other beautification programs including examples in Paris and Vienna), encouraged Reid's endeavours in Toronto, his home city. ${ }^{26}$

\section{The Murals in the Toronto Municipal Buildings, 1897-1899}

George Reid's murals in the lobby of the Toronto Municipal Buildings represent the culmination of his civic art aspirations in the 1890s. Collectively entitled Hail to the Pioneers, Their Names and Deeds Remembered and Forgotten, We Honour Here, the murals were also the first project supervised by the Advisory Board of the TGCA. They were proposed to Toronto City Council in 1895 by the Society of Mural Decorators (which Reid had founded) to adorn the interior of the structure designed by Edward James Lennox (1855-1933). The original plan was ambitious in that it accounted for the decoration of the interior of the Council Chamber, including the stairway and entrance. A competition open to all local artists was proposed for the remaining walls of the building. ${ }^{27}$ The 1895 proposal called for the advisory participation of "artists, architects, and public spirited men of taste and knowledge. ${ }^{28}$ In 1901, after the murals were completed, the Guild embraced another related project: city planning (see Chapter One). ${ }^{29}$ Reid's murals in the Toronto Municipal Buildings appeared at a propitious moment in history: as civic beautification rose in popularity following the 1893 World's Columbian Exposition and as Reid's affinity for murals reached an apex. The model of the collaboratively planned and executed Exposition encouraged Reid's enthusiasm for unity within the arts. ${ }^{30}$ Furthermore, Reid's personal interest in applying murals to civic spaces matured because their large format permitted grandiose, moral-imbued themes and 
the public setting maximized public access. ${ }^{31}$ Following a sojourn in Paris in 18881889, where he viewed Puvis de Chavanne's mural program at the Paris Hôtel de Ville, Reid had returned to Canada intent on lobbying for the significance of mural painting. ${ }^{32}$ The use of public wall space for the display of morally inspiring artwork fostered his enthusiasm for the medium..$^{33}$ Reid conceptualized mural painting as the integration not only of painting and architecture, but also of aesthetic traditions with Canadian history, cementing a link between art, community and national identity:

As there have been from time to time revivals of art activity of various kinds and degrees, due to enlightenment and the development of an individual and national spirit, so in our own time has arisen a movement which is making itself felt among painters and sculptors and is directing their attention towards the more adequate decoration of architecture. The movement among painters is shown in the permanent wall decorations of all classes of buildings, but mainly in those of a public nature, their purposes requiring a more heroic treatment. ${ }^{34}$

Murals were a natural extension of Reid's genre paintings, such as Mortgaging the Homestead (1890), which was exhibited at the 1893 Exposition and won a bronze medal (Fig. 14). ${ }^{35}$ His easel paintings from this period could be grand in scale, and were popular with the public for their "strong native sentiment." 36 Throughout the 1880 s and the early 1890 s, Reid focused his talents on genre paintings that incorporated the techniques of the academic tradition with themes derived from his childhood in rural Canada. ${ }^{37}$ Reid's admixture of centuries of artistic traditions with scenes of the young Canadian nation was emblematic of the nationalist spirit of the time. For instance, as early as 1894 W.A. Sherwood recognized the necessity of cultivating a national character in Canada. ${ }^{38}$ In "A National Spirit in Art," he wrote:

Not only in church, military and political life, does art wield its great influence. It enters the social and domestic sphere with perhaps more vital 
force. Genre pictures awaken a love for the humbler walks of life, and a consequent respect for those therein depicted. We are touched by their sorrows and we are cheered by their joys, as we enter with unfeigned affection into the spirit of rural life ... We may fairly conclude that in the awakening of such associations, the love of home which broadens into national pride is fostered and developed. ${ }^{39}$

Reid and the Society of Mural Decorators' mission to decorate the walls of the Toronto Municipal Buildings was plagued by difficulty from the first submission of the proposal in 1895. The largest hindrance was monetary: the city argued that due to the high cost of completing the structure, it was unable to finance further adornment inside the building. ${ }^{40}$ In 1899 , Reid wrote about the task of securing the commission:

It seemed desirable that at the very commencement of the use of this noble building there should be in constant evidence some touch-stones of modern decoration, so that we may be saved from mere commercial decoration such as we have heretofore had in Canada, and also from wall paintings conceived in a proper enough spirit, but executed without regard to the true principles of decoration. ${ }^{41}$

Following a trip to Paris in 1896, Reid redoubled his efforts to adorn the interior of the Municipal Buildings. He was confident that the murals were a necessary element of the structure, and eventually opted to complete two decorative panels without remuneration. This was in accordance with the stated objectives of the TGCA, which declared that any work completed by members of its Advisory Board would not receive payment. ${ }^{42}$ Reid's voluntary act demonstrates the degree to which he and the TGCA believed in the merit of civic art, and in the cultural value it held for the city.

In 1897 , therefore, Reid proposed to complete two panels that would not interfere with the original proposal outlined by the Society of Mural Decorators. He believed that once his work was completed and exhibited to the public, sufficient interest would be 
aroused to convince city council to fund the series of murals from the original proposal. ${ }^{43}$ Upon the unveiling in 1889, TGCA president Byron Edmund Walker commented:

It must be because of our intensely utilitarian habits that thus far in Canada this phase of art has been neglected and some great buildings have been allowed to remain for years with all the ugliness of bare walls and without even a serious protest from the public. We have only to look at this beautiful hall, however, to realize that this is a fitting time and place to begin a new era in Canada for this particular art. ${ }^{44}$

The completed murals (Figs. 15-16) are connected by spandrels decorated with female personifications of Discovery, Fame, Fortune, and Adventure (Fig. 17). Bands bearing the names of influential Canadians enclose the pair of larger murals, entitled The Arrival of the Pioneers and Staking a Pioneer Farm. As W.A. Sherwood related in his 1894 essay, it was the obligation of Canadians to record their history: "It is surely incumbent upon us to keep intact, as far as in our power lies, every phase of life and thought of the time in which we live. By the principles and practices of preservation, a good sentiment is nurtured. ${ }^{, 45}$ Reid's efforts to reconstruct and venerate Canadian history can be seen as emblematic of both nationalism in Canada and of his desire to utilize art for civic purposes of citizenship.

After Reid began his murals, city planners designed a new public square outside the Toronto Municipal Buildings. Plans for the proposed Victoria Square began to appear in 1897 (Fig. 18). The square, which was to be named in honour of the reigning British monarch, would also provide necessary park space in the congested downtown and a vista favouring the façade of the new building. ${ }^{46}$ Although Victoria Square never progressed beyond the planning stage,$^{47}$ the proposal accords with the civic art 
philosophy of collaboratively embellishing the inside and surroundings of public buildings.

George Reid's enduring interest in murals represented his attempt to "resolve the twin gods of his youth, to enlighten and uplift the Canadian public" ${ }^{" 48}$ even though the murals in the Municipal Buildings did not receive unanimous praise from critics and the public upon their unveiling on 16 May, $1899 .{ }^{49}$ However, over thirty years later, sculptor Emanuel Hahn (1881-1957) pointed to the continued resurgence in mural painting (as of 1932) as an "encouraging sign" that purely studio-based artwork was seeing a decline in Canada. ${ }^{50}$ The pioneering efforts of Reid and professional organizations including the TGCA and Society of Mural Decorators would multiply as esteem for Canadian civic art escalated in the twentieth century. A clear example of this was a series of exhibitions in the 1920s and 1930s that were dedicated to the allied arts: exhibitions committed to collaboration between the arts and to the importance of a civic role for them.

\section{The Biennial Exhibitions of Architecture and the Allied Arts, 1927-1939}

"It is claimed by the Architects responsible for the holding of the Exhibition, that an isolated art does not exist, but that all the artistic products of civilization fit into the architectural scheme of things." - H.M. Ridley, 1927

In 1927, a group of Toronto-based architects perceived a social obligation to decipher the "ways and means of making Canadian architecture and its associated arts better known. ${ }^{.52}$ Hence materialized a modern professional architectural association that endorsed the allied arts and that was formed under the aegis of the Toronto Chapter of the Ontario Association of Architects (OAA): the Diet Kitchen School of Architecture. The 
launch of the Diet Kitchen School was intended to place architecture in the vanguard of Canadian art. Its formation was described thus in 1927:

The name arose in this wise: about a year ago, a little group of leading Architects, members of the Toronto Chapter of the Ontario Association of Architects, met every day at the Diet Kitchen on Bloor St., Toronto, for lunch, and it was while thus convivially engaged, that they began to discuss ways and means for making Canadian Architecture and the allied arts better known [through a distinctive style]. Soon their discussions had crystallized into definite plans and a definite movement, - and the 'Diet Kitchen School of Architecture' quite naturally evolved. ${ }^{53}$

Contemporary scholars have described the scarcely remembered association as "an informal discussion group of architects" 54 and "a tongue-in-cheek attempt to inject spirit and debate into the architectural community and come to terms with the everchanging and radical new forces shaping current architectural trends. ${ }^{.55}$ The architects of the Diet Kitchen School and its sister association the OAA publicized the allied arts through the Biennial Exhibitions of Architecture and the Allied Arts, which were held every two years (1927-1939) at the Art Gallery of Toronto (AGT). The shared administration for these exhibitions can be explained in part by the participation of William Lyon Somerville (1896-1965), who was both a member of the short-lived Diet Kitchen School and president of the OAA when the exhibitions began in 1927.

The catalogue of the First Biennial Exhibition summarizes the purpose of these events. This text was repeated verbatim in the catalogues of the second and third exhibitions (1929 and 1931):

The object of this association of Architecture with the Allied Arts is threefold. First, to call attention to the general standard of design and craftsmanship existing in Canada to-day; second, to develop the possibilities of co-operation between the various branches of the Allied Arts among themselves and with Architecture - and third, to increase the interest of those who support these Arts by their patronage in the 
development of local craftsmanship and design to the furtherance of a distinctive development of style in Canada. ${ }^{56}$

The biennial exhibitions have been described as "the most public and significant achievements" of the Toronto Chapter of the OAA. ${ }^{57}$ As one review of the 1927 exhibition observed: "Never before were so many of the arts gathered together at one time in these halls of beauty." allied arts, and architecture. Samples of fine art and crafts were displayed under the aegis of the allied arts, including antique and modern furniture, garden furniture, mural decoration, small decorative objects, sculpture, and landscape architecture. ${ }^{59}$ The reason for including the allied arts in an exhibition organized by architects was explained thus: "While various Architectural Associations have held exhibitions of their work from time to time, this is the first attempt that has been made in Canada by any Association to show the work of the various Allied Arts which, combined with Architecture, have a strong influence on the artistic life of the country." included photographs of buildings, architectural drawings and sketches, models, objets d'art, and a section of miscellaneous items (Fig. 19). ${ }^{61}$ A review of the Fourth Biennial Exhibition (1933) documented the popularity of the allied arts in these exhibitions:

The public and press are loud in their praise of the recent Toronto Chapter Exhibition, and the architects are happy as they well deserve to be. There can be no doubt but that this exhibition, together with its predecessors, has awakened in the minds of the local public, a considerable amount of interest in architecture and architects. It is logical that an increasing appreciation on the part of the public, means an increasing responsibility on the part of the architect, and as we are constantly reminded, if architecture is to be a vital force in the community, it must keep pace with the progress of our times. ${ }^{62}$ 
The biennial exhibitions were successful in disseminating the allied arts to the general public, particularly as they attracted plenty of visitors. The inaugural exhibition saw 29,000 guests within a two-week period. ${ }^{63}$ Furthermore, a review of the 1933 exhibition remarked that "the public manifested its interest whole-heartedly" when 3,500 guests visited within three hours on a Saturday. ${ }^{64}$ The catalogue of the Fifth Biennial Exhibition (1935) noted an increase in the public's interest in architecture, that most observably civic of arts: "That this new interest in architecture is a very real one, is shown by the attendance during our four exhibitions in the years 1927, 1929, 1931 and 1933, which reached a total of 100,360. These figures speak for themselves." explained the public's fervent patronage of Canadian art and architecture in a review of the 1927 exhibition:

What were the reasons for this patronage on the part of the public? First A general awakening of interest on the part of our people as to the value of architecture in relation to our everyday life, and to the fact that architecture is a fine art, and again to a realization that there is such a thing as Canadian architecture. Second - The coupling of the allied arts with the purely architectural side of the Exhibition. Third - The great diversity of the exhibits. Fourth - The effective handling of the exhibits. ${ }^{66}$

Lyle thus indicated that the public's reception of the inaugural exhibition accorded with the objectives of the organizers, as recorded in the foreword of the first catalogue. One of the purposes of the biennial exhibitions was to foster patronage within Canada. Lyle's review, published three months after the exhibition closed, indicates that the architects were successful in this aspect. A further goal of the architects who coordinated the exhibitions was to propagate modernism within Canadian art and architecture. In this regard John Lyle's review noted: "One heard the remark time and time again that if some of our craftsmen would branch out a little along modern lines and, 
while holding to sound traditions, endeavour to strike a new and Canadian note the future is full of promise. ${ }^{967}$ This emphasis on a distinctly Canadian expressionexemplified in Lyle's use of Canadian faunal imagery for the sculptural adornment of his own buildings - had obvious ties to the ideals of civic expression and responsibility. ${ }^{68}$

The catalogue of the second show (1929), was the first to directly connect modernism and civic responsibility with the biennial exhibitions:

Since the last Exhibition Canada has become distinctly alive to the influences of the so-called "modern style" and we have endeavoured to give expression to this in the Exhibition. This style, which is as yet - at least in this country - only in its formative stages, shows promise of a great future, provided that the work is carried out subject to the laws of good taste, and not, as is often the case, as an opportunity to provide a new sensation. ${ }^{69}$

A section devoted to the allied arts in the catalogue of the Fifth Biennial Exhibition (1935) lists several members of the Sculptors' Society of Canada and the Canadian Society of Landscape Artists, ${ }^{70}$ a significant inclusion. The catalogue also indicates a resurgence of interest in the application of beauty to civic spaces: "There is today a reawakened interest on the part of the Canadian public in all that pertains to beauty, and particularly beauty as applied to the designing, decorating, and furnishing of both our public buildings and our dwellings." J11 John Lyle, an advocate for urban beauty, shared this sentiment in a 1928 essay titled "Civic Beautification." Here Lyle called for the application of beauty to the retail industry: "Beauty is the great modern business tool,,"72 he wrote, while simultaneously admonishing merchants for not beautifying their establishments: “[Toronto's] people all seem to be so satisfied and so steeped in their own ugliness. ${ }^{.73}$ Lyle proposed to rectify the industrial appearance of much modern architecture by formulating a new style of Canadian civic decoration. His providential 
proposal would achieve both the beautification of the city, and the formation of a distinctly Canadian decorative style.

The Seventh (and final) Biennial Exhibition of Architecture and the Allied Arts transpired in 1939. The fact that the exhibitions continued to appear with substantial success throughout the Depression era indicates the authority of the allied arts concept. As well, the seven exhibitions were successful in fostering support for their basic premise. One reviewer noted that he wished to see the influence of the allied arts carried through to the next decade: "We sincerely hope that the post-depression era will bring to architects many opportunities to blaze a new trail with the experiences of the past to guide." 74

\section{John Lyle's Renovations to 'Parkwood,' The McLaughlin Family Estate}

Aside from his support for the Biennial Exhibitions of Architecture and the Allied Arts, one of John Lyle's greatest contributions to the field of the allied arts was the application of Canadian motifs to civic buildings through sculpture, as embodied through his displays at the third and fourth biennial exhibitions. Lyle's confidence in "the didactic element of architecture - the ability of buildings and their decoration to transmit and enforce the values and history of the culture which built it," -- was derived from beauxarts teachings ${ }^{75}$ and formed the foundation for his campaign for a vernacular style of ornamentation that would speak directly to the surrounding community.

However, the concept of the allied arts extended beyond the public sphere. An exemplar of Lyle's vision of the allied arts applied to a private residence is the Parkwood Estate of Colonel R.S. McLaughlin in Oshawa. The first phase of construction at 
Parkwood was completed in 1917 according to the Georgian revival design of architects Darling and Pearson, and at a cost of $\$ 100,000{ }^{76}$ The interior housed fine art by such Canadian artists as Frederick Challener (1869-1959), whose The Enchanted Wood mural series from the 1920s featured portraits of McLaughlin family members (Fig. 20).$^{77}$ The 1930 s witnessed a second phase of construction, including the addition of a sunroom designed by Darling and Pearson, and interior renovations by Lyle. ${ }^{78} \mathrm{~A}$ series of murals by Frederick Haines (1879-1960) in the entrance hall depicts the formal gardens and sculpture at the estate (Fig. 21) ${ }^{79}$ This represents the allied arts at their best.

The Parkwood renovations in the 1920s and 1930s coincided with the proliferation of the concept of the allied arts. Landscape architects Howard (1881-1965) and Lorrie Alfreda Dunington-Grubb (1877-1945) were enlisted in 1927 to renovate the extensive gardens surrounding the estate, originally designed by W.E. Harries and A.V. Hall. As founding members of the Canadian Society of Landscape Architects and close acquaintances of William Somerville and Lyle, the Dunington-Grubb team was a logical selection to rejuvenate the gardens. Indeed, the professional relationship between the Dunington-Grubbs and the architects was formally acknowledged in the Fourth Biennial Exhibition of Architecture and the Allied Arts (1933), which included photographs of the landscape architecture completed at the estate. ${ }^{80}$ The Dunington-Grubbs designed a sunken garden, the south terrace, the sundial garden, a tennis court and an Italian garden on the grounds (Figs. 22-23). ${ }^{81}$ Many of these were adorned with large-scale sculptures (Fig. 24), in accordance with a seminal essay on the subject by Lorrie Dunington-Grubb (see next section). ${ }^{82}$ 
The largest addition to the Parkwood estate followed the work of the Dunington-Grubbs, when Lyle was hired to adorn the grounds with a formal fountain and teahouse between 1935 and 1936. The main fountain is approached from a balcony overlooking the reflecting pools and teahouse, creating a vista along a length of shallow pools (Fig. 25). At the base of the balcony is a set of staircases flanking a small fountain (Fig. 26), with water flowing from the figures of two bronze geese and a head of Neptune (Figs. 27-28). ${ }^{83}$ Opposing the balcony is a long, shallow pool punctuated by taller fountains: “The layout of the walks, lawns, retaining walls and plantings was designed to enhance the impression of length." was utilized by the McLaughlins for hosting events. ${ }^{85}$ Designed in the moderne style, the minimal ornamentation on this structure is reduced to a shell pattern and large vases set in niches (Fig. 29). ${ }^{86}$

The Seventh Biennial Exhibition of Architecture and the Allied Arts (1939) featured ten photographs of Lyle's work on the garden, ${ }^{87}$ which developed the original landscaping established by Harries \& Hall and the Dunington-Grubbs, both designed to complement the artistic integrity of the house. The design of the formal garden garnered Lyle a bronze medal at the Eighth Annual Exhibition of the Royal Architectural Institute of Canada. ${ }^{88}$ In 1935 , Lyle began renovations in the interior of the house, notably to the bedroom of Colonel McLaughlin, also designed in the moderne style. Lyle designed a series of decorative items for the space, including a relief panel above the fireplace featuring a stylized stag and doe set in a landscape (Fig. 30), and a series of twenty-one pieces of furniture (Fig. 31) ${ }^{89}$ A meander motif is repeated throughout the rest of the room, as is a soothing colour palette dominated by greens. ${ }^{90}$ Lyle's design for the 
bedroom at Parkwood has been described as "one of [his] most restful and harmonious interiors,"91 a testament to the efficacy of comprehensive design. Shortly after, Lyle converted the former children's playroom into an art gallery, which displayed art favoured by Colonel McLaughlin and his daughter, Isabel. ${ }^{92}$

Lyle's work inside and outside the estate shows the extent to which the allied arts concept had infiltrated the work of some Canadian professionals. Not only were architects, artists, landscape architects and engineers collaborating on projects, but individuals were experimenting with all of the arts at their disposal. William Somerville in fact recommended that in most cases architects should be responsible for both the exteriors and interiors of spaces: "One may ... be permitted to refer to the architect of today as a soloist in designing the exterior of a building, and as the leader of the orchestra in the design of the interior. Unless he is permitted to act as such, the chances of a harmonious and satisfying rendition [are] very remote indeed." ${ }^{\text {93 }}$ Somerville argued that the term 'architect' implied proficiency in all the "component arts," and that Canadian practitioners were capable of such integration. ${ }^{94}$ Somerville's contention that the architect should be accountable for exterior and interior designs alike was carried through to completion by Lyle's work at Parkwood. In its harmonious marriage of the arts, Parkwood thus functioned as a private-sphere equivalent of such public civic art projects as George Reid's mural paintings in the Toronto Municipal Buildings.

\section{The Allied Arts in Circulation}

Pairing contemporaneous publications by two Canadian women artists further elucidates the concept of the allied arts. Much as professional arts associations 
manifested themselves in the early decades of the twentieth century, a proliferation of periodicals influenced by notable journals such as Canadian Architect and Builder also appeared. These included Canadian Homes and Gardens and Canadian Art, among others. Following the trend of popularizing specialist disciplines for the public through periodicals, landscape architect Lorrie Dunington-Grubb and sculptor Frances Loring each published an essay on the application of sculpture in garden settings. DuningtonGrubb published her article, "Sculpture as a Garden Decoration," in 1927, and Loring followed with "Sculpture in the Garden" in 1943.

Both essays call for the continued integration of sculpture with gardens, and for increased public support for bringing together these two forms of Canadian fine art. For instance, Dunington-Grubb recommended: “All encouragement possible should be given to those of our Canadian artists who are trying to popularize this form of art." ${ }^{.95}$ Her essay highlights samples of Canadian sculpture positioned in gardens, notably a mermaid and child fountain by Loring and two projects by Florence Wyle. ${ }^{96}$ This theory was also applied to the Dunington-Grubbs' landscape architecture at the Parkwood estate, in which sculpture by notable Canadian artists (including Loring and Wyle) accentuated many of the formal gardens (Figs. 32-34).

In accordance with the historical legacy of incorporating sculpture into garden settings, Loring concurred that the two are irrevocably intertwined: "The formal garden practically requires sculpture, seeming incomplete without it. Even the small intimate garden, if it has no sculpture, lacks a centre around which the life of the garden can be organized ... only sculpture successfully lifts the garden out of the realm of the horticultural display."97 Sixteen years earlier, Dunington-Grubb's entire essay had been 
formulated as a response to criticism of garden sculpture and to the lack of support for landscape architecture on the part of the Canadian public. To substantiate her argument, Dunington-Grubb - as Loring would do in 1943 - enlisted the support of the history of sculpture within formal gardens: "Far back in antiquity, as far back indeed as records take us, we find that architectural features and sculpture were regarded not merely as casual embellishments but necessary parts of any well ordered garden. The idea that such introductions are superfluous is undoubtedly a modern retrogression in garden design. 998

Both the Loring and the Dunington-Grubb articles acknowledged the ideal of the allied arts, in that they not only insisted on the necessity of integrating sculpture with gardens, but because they emphasized the well-planned garden in relation to its architectural surroundings. Loring wrote: "To achieve harmony everything should be visualized as part of one governing plan. A garden can become a single unit only if the personality of the owner, the house, the garden, the sculpture and every flower and tree are conceived and built up as one scheme." $"$ Likewise, Dunington-Grubb argued: "It is only when the landscape architect has a sympathetic and technical knowledge of architecture ... that any true harmony between the house and the garden can be hoped for. The two should be designed together as a single unit, each inseparable from the other."100 This opinion was prevalent in Canadian art of the 1930s and 1940s. For example, sculptor Emanuel Hahn agreed that "to beautify our parks with sculpture, where natural surroundings can add so much to the effectiveness of a work," Hahn's wife, sculptor Elizabeth Wyn Wood (1903-1966), noted in 1948 that whereas indoor "salon sculpture" dominated the decade from 1928 to 1938 , the influence of the 
allied arts resulted in a "reversal of emphasis and of patronage" 102 in Canadian sculpture after 1938: "The most vigorous Canadian sculpture is to be found chiefly in two places: in permanent installation on buildings or in parks, on the one hand, and in the home of the people on the other. The architect and the family have become the new appreciators of sculpture in Canada." 103 The new public and private patrons identified by Elizabeth Wyn Wood included the McLaughlins of Parkwood, in Oshawa. ${ }^{104}$

This chapter has discussed the importance of the idea of the cross-fertilization of the arts, characteristic of the allied arts movement, for individual artists and for organizations (such as the Diet Kitchen School and the Ontario Association of Architects). While some of the results of this collaborative work were public (the Reid murals in the Toronto Municipal Buildings), much of it was private (such as the Parkwood estate), with the Biennial Exhibitions of Architecture and the Allied Arts presenting examples of both. The next chapter will shift to much larger-scale, government-initiated and-funded projects that went beyond the integration of the traditional fine arts, to consider examples of large-scale improvement projects that relied heavily upon the varied approaches to urban design that were explored in Chapter One. 


\section{Endnotes to Chapter Two}

'Cauchon, "Town Plannıng," 165

${ }^{2}$ Hamılton MacCarthy, "The Aesthetıc Unity of the Fine Arts - Most Especially in Relation to Architecture," CAB 8 no 3 (Mar 1895) 46

${ }^{3}$ George A Reıd, "Mural Decoration," The Canadıan Magazıne 10 no 6 (Apr 1898) 504

${ }^{4}$ Frederıck Ackerman, "The Architectural Side of City Plannıng," in Proceedings of the Seventh Natıonal Conference on City Planning, Detrott, June 7 9, 1915 (Cambridge Unversity Press, 1915) 110

${ }^{5}$ George Reid rarely used the term 'cıvic art' However, his particıpation in the Toronto Guıld of Civic Art and his constant advocating for public decorations indicate that he was certainly aware of the practice of clvic art

${ }^{6}$ George A Reıd, "Applıed Art," CAB 13 no 3 (Mar 1900) 55

${ }^{7}$ Christıne Boyanoskı, Sympathetıc Realısm George A Reıd and the Academıc Tradition (Toronto Art Gallery of Ontar1o, 1986), 9

${ }^{8}$ Ibıd , 9 Boyanoskı outlınes the degree to which Reid was involved in the integration of modernısm with tradition, and the reception he received in the $1890 \mathrm{~s}$

${ }^{9}$ Pepall, 13-14

${ }^{10}$ Chris Dickman, G.A Reld, Toward a Union of the Arts (Durham Durham Art Gallery, 1985), 17 Dickman points to the political truisms that George Reid shared with the Arts and Crafts movement, including the hardships placed on society as a result of industralization Dickman refers to Re1d's "popuhst views" and "reformust bent" in the same context (21)

${ }^{11}$ Ibıd, 13

${ }^{12}$ Ibid , 13, 17

${ }^{13}$ Newton MacTavısh, The Fine Arts in Canada, 1925 (Reprınt, Toronto Coles Publıshıng, 1973), 97

${ }^{14}$ Ibid, 96

${ }^{15}$ George A Reid in 1896 quoted at Cybermuse, the Natıonal Gallery of Canada's Onlıne Resource Accessed Sept 13, 2010

http //cybermuse gallery ca/cybermuse/enthusiast/thirties/artist e jsp?artıstid $=4583$

${ }^{16}$ Robunson, Modern Civic Art, or, the City Made Beautiful, 29

${ }^{17}$ Reıd, "Mural Decoratıon," CAB 11 no 1 (Jan 1898) 15

is George A Reid, "Architecture fiom an Artıst's Standpoint," CAB 4 no 4 (Apr 1891) 44

${ }^{19}$ Murıel Miller, George A Reıd, A Btography, 1946 (Reprint, ed Ian R Coutts, Toronto Summerhıll Press, 1987), 72

${ }^{20}$ Mavor, 88 
${ }^{21}$ Ibid, 89

${ }^{22}$ Ibid , 89-90

${ }^{23}$ Dickman, 9

${ }^{24}$ Re1d, "Mural Decoration," CAB 11 no 1 (Jan 1898) 13

${ }^{25}$ Reıd, "Mural Decoratıon," The Canadıan Magazıne 10 no 6 (Apr 1898) 501

${ }^{26}$ Re1d, "Mural Decoration," CAB 11 no 1 (Jan 1898) 13-14

${ }^{27}$ Pepall, 32-33

${ }^{28}$ Ibid , 33

${ }^{29}$ Osbaldeston, 22

${ }^{30}$ Pepall, 29

${ }^{31}$ Boyanoskı, Sympathetıc Realısm, 37

${ }^{33}$ Dickman , 25

${ }^{33}$ Denmıs Reid, A Conctse History of Canadian Paintıng (Toronto Oxford Unıversity Press, 1973), 101

${ }^{24}$ Reıd, "Mural Decoratıon," CAB 11 no 1 (Jan 1898) 13

${ }^{35}$ Boyanosk1, Sympathetıc Realism, 33

${ }^{36}$ Re1d, A Concise History of Canadian Painting, 101

${ }^{37}$ Boyanoskı, Sympathetıc Reallsm, 33

${ }^{38}$ W A Sherwood, "A Natıonal Spırıt in Art,' The Canadıan Magazıne 3 (Oct 1894) 498

Ibid , 499

${ }^{40}$ Pepall, 3233

${ }^{41}$ George A Reid, "Mural Decoratıons in the New Munıcıpal Bulldings, Toronto," CAB 12 no 5 (May 1899) 98

${ }^{42}$ Toronto Gunld of Civic Art, By Laws of the Toronto Guld of Civic Art (Toronto Oxford Press, 1906), 6

${ }^{43}$ Miller, 82

${ }^{44}$ B E Walker, as quoted in Reid, "Mural Decoratıons in the New Muncipal Buılding s, Toronto," 98

${ }^{45}$ Sherwood, 501

${ }^{46}$ Osbaldeston, 78 
${ }^{47}$ In Unbult Toronto A History of the City that Might Have Been (2008), Osbaldeston notes Victoria Square among other civic projects that were proposed in 'Toronto, but never completed (78 83)

${ }^{48}$ Dickman, 31

${ }^{49}$ See Pepall, 46-47, for an account of the response the murals received upon unvelling

${ }^{50}$ Emanuel Hahn, “Architectural Sculpture," JRAIC 9 no 8 (Aug 1932) 194

"H H M Ridley, "Canada's Architectural Movement, 'The Diet Kitchen' School and Its Propaganda for the Art," Saturday Night (Mar 12, 1927)

${ }^{52}$ Geoffrey Hunt, John M Lyle, Toward A Canadlan Architecture (Kingston Agnes Etherıngton Art Centre, 1982), 46

${ }^{53}$ Ridley, "Canada's Architectural Movement"

${ }^{54}$ Trevor Boddy, "Regınalısm, Natıonalısm, and Modernısm The Ideology of Decoratıon in the work of John M Lyle," Trace A Canadıan Review of Architecture 1 (Jan 1981) 12

${ }^{55}$ Glenn McArthur, A Progressive Traditıonalist John M Lyle Architect (Toronto Coach House Books, 2009), 125

${ }^{56}$ OAA, Catalogue of the First Blennial Exhbbtion of Architecture and the Alled Arts (Toronto AGT, 1927), 3

${ }^{57}$ Geoffrey Simmins, Ontarto Association of Architects A Centennial Htstory 18891989 (Toronto Ontario Association of Architects, 1989), 195

${ }^{58}$ Ridley, "Canada's Architectural Movement"

${ }^{59}$ OAA, Catalogue of the First Biennial Exhibition of Architecture and the Alled Arts (Toronto AGT, 1927), 68 Other arts that were exhibited include textıles, metal work, staned glass, porcelan, vases and decorative pieces, illumınated letterıng, bookbindıng, ceramıcs, terra cotta, coloured tıles, wall paper, and carvings

${ }^{60}$ Ibid , 3

${ }^{61}$ Ibıd , 1530

6) Arthur Eadie, "Whither Are We Bound" JRAIC 10 no 3 (Mar 1933) 47

${ }^{63}$ John M Lyle, "The Alled Arts at the Recent Toronto Chapter Exhbition," JRAIC 4 no 5 (May 1927) 164

64 "Notes from the Architects' Show," Canadian Homes and Gandens 10 no 9 (Mar 1933) 20

${ }^{65}$ OAA, Catalogue of the Fifth Btennial Exhibition of Architecture and the Allued Arts (Toronto AGT, 1935), 4

${ }^{66}$ Lyle, "The Allıed Arts at the Recent Toronto Chapter Exhibition," 164

${ }^{67}$ Ibid , 169 
${ }^{68}$ Lyle articulated his vision for Canadian expression through two seminal texts on Canadian sculptural decoration "Canadıan Decoratıve Forms," JRAIC 9 no 3 (Mar 1932) 65-70, and "Canadian Ornament Goes Native," American Architect 140 no 2602 (Dec 1931) 34-39

${ }^{69}$ OAA, Catalogue of the Second Btennial Exhbitton of Architecture and the Allied Arts (Toronto AGT, 1929), 2

${ }^{70}$ OAA, Catalogue of the Fifth Blennial Exhlbition of Architecture and the Allted Arts (Toronto AGT, 1935), 16 References to work completed by CSLA members appears throughout all seven catalogues of the Biennial Exhibitions For example, the catalogue of the Third Biennial Exhibition (1931) mentions the collaborative work of William Lyon Somerville and H B \& L A Dunington-Grubb on McMaster Unıversity in Hamilton (19)

${ }^{71} \mathrm{Ib}$ Id , 2

${ }^{72}$ John M Lyle, "Civic Beautıficatıon," JRAIC 5 no 7 (July 1928) 238

${ }^{73}$ Ibid , 239

${ }^{74}$ Eadie, 54

${ }^{75}$ Boddy, 11

${ }^{76}$ Stephanı Beatty and Susan Gale Hall, Parkwood (Erın Boston Mills Press, 1999), 14

${ }^{77}$ Ib1d , 28

${ }^{78}$ Ibid, 18

${ }^{79} \mathrm{Ib} 1 \mathrm{~d}, 22$

${ }^{80} \mathrm{OAA}$, Catalogue of the Fourth Biennial Exhibition of Atchitecture and the Alled Arts (Toronto AGT, 1933), 10

${ }^{81}$ Beatty and Hall, 55

${ }^{82}$ In actual fact, both of the Dunington-Grubbs published extensively on the subject of landscape architecture See particularly H B Dunıngton-Grubb's paper "The Country Estate," Canadian Homes and Gardens (Nov 1933) 24-25, 54

${ }^{83}$ Hunt, 120

${ }^{84}$ Ibıd , 120

${ }^{85}$ Beatty and Hall, 60

${ }^{86}$ Hunt, 120

${ }^{87}$ OAA, Catalogue of the Seventh Blennial Exhlbition of Architecture and the Alled Arts (Toronto AGT, 1939), 7-8 
88 "Garden at 'Parkwood' for Colonel R S McLaughlın, Oshawa, Ontario John M Lyle, Architect," JRAIC 16 (March 1939) 63 This excerpt is essentially a photograph of the formal garden looking towards the tea house, with a caption statıng that Lyle had won a Bronze Medal at the Eighth RAIC exhibition

${ }^{89}$ Beatty and Hall, 35

${ }^{90}$ Hunt, 123

${ }^{9]}$ Ibid , 123

${ }^{92}$ Beatty and Hall, 33 The Catalogue of the Fourth Biennial Exhlbitton of Architecture and the Alled Arts (1933) records that Isabel McLaughlın had a display of forty-seven paintıngs and drawıngs displayed in the "Young Canadians" section of the exhıbition (20) Isabel became a notable woman painter in the history of Canadıan art, and was a founding member of the Canadıan Group of Painters in 1933

${ }^{93}$ Willıam Lyon Somerville, "Why the Interior Decorator?" JRAIC 9 no 6 (June 1932) 142

${ }^{94}$ Ibıd , 143

${ }^{95}$ Lorrie A Dunington-Grubb, "Sculpture as a Garden Decoration," Canadian Homes and Gardens 4 no 3 (Mar 1927) 52

${ }^{96}$ While Dunington-Grubb has included images of these sculptures in her text, she does not directly mention either sculptor outside of the caption It is also significant that other images are included, but those responsible for these objects are not mentioned This omission points to the professional and personal relatıonships between Lorrie Dunıngton-Grubb, Frances Lorng and Florence Wyle, who knew each other through the Toronto branch of the Women's Art Association of Canada

${ }^{97}$ Frances Lorıng, "Sculpture in the Garden," Canadlan Art 1 no 2 (Dec-Jan 1943-44) 65

${ }^{98}$ Dunıngton-Grubb, "Sculpture as a Garden Decoratıon," 17

${ }^{99}$ Loring, 64

${ }^{100}$ Dunington-Grubb, "Sculpture as a Garden Decoratıon," 18

${ }^{101}$ Emanuel Hahn, "Sculpture in Canada," in Yearbook of the Arts in Canada, 1928-1929, ed Bertram Brooker (Toronto Macmillan Company of Canada Limited, 1929), 93

${ }^{102}$ Ibıd , 15

${ }^{103}$ Ibıd , 16

${ }^{104}$ The McLaughlın famıly itself personified the allıed arts concept The patriarch of the famıly, Colonel R S McLaughlin, was a successful auto baron but also a great patron of the arts This fact is corroborated by the large amount of fine art displayed inside and outside the house Group of Seven pantıngs hung in the McLaughlın's bowlıng alley, and the formal dinıng room was adorned with Paul Peel's After the Bath (1890) before the works were donated to the McMichael Canadian Art Collection, and the Art Gallery of Ontarı, respectively Furthermore, Oshawa's public art gallery is named after Robert McLaughlın, father of the Colonel and also a patron of the arts Colonel R S McLaughlin's name as a sponsor also appears throughout the catalogues from the Biennial Exhibitions, as he loaned furniture and other decorative items to the exhibitions of the Allied Arts 


\section{Chapter Three - Regional Beautification: Civic Art in Hamilton}

"In 1930, when work commenced it was hard to visualize the future which progress would bring, and even now it was difficult for the uninitiated to appreciate the beauty which would be unfolded as the planting developed. However, experts, who knew of these things, had assured the city of the fact that the [northwestern] entrance [designed by John Lyle] promised to be second to none on this continent." - Hamilton Spectator, 1932

From 1915 to the late 1930 s, the city of Hamilton experienced a flourishing of progressive civic beautification that abided by the model of comprehensive city planning. For a period spanning over two decades, Hamilton became the locus for a concentration of hybrid City Beautiful and City Scientific planning, as well as for an emphasis on the concept of the allied arts. Hamilton thus constitutes a rare example of extensively realized Canadian civic art, as the municipality developed its own method of city planning in the face of national debate on the subject. ${ }^{2}$ This chapter offers a study - that of the city of Hamilton - of the successful practical application of the ideology of urban planning and beautification, as it was previously discussed in this thesis.

The adoption of a comprehensive planning philosophy in Hamilton served three essential purposes: beautification, edification, and circulation. These are illustrated by the preponderance of civic projects undertaken as of 1915, including a network of public parks throughout the city, notably Gage Park (1917) and Royal Botanical Gardens (begun in 1930); the construction of McMaster University's Hamilton campus (begun in 1928); and the city's redesigned northwestern entrance and High-Level Bridge (completed 1932), which included the construction of Canada's first superhighway, the Queen Elizabeth Way (initiated in 1931). 
This survey thus illustrates a singularly thoughtful regional response to the influence of city planning and reform in North America: a response notable both for the abundance of projects undertaken in Hamilton and for the number of endeavours that were completed despite some modifications resulting from the First World War and Great Depression. Civic art in Hamilton testifies to the reason for which a city would undertake urban reform in the first half of the twentieth century: to unite beauty with utility and to make the best possible modern city.

\section{Noulan Cauchon and The Legacy of Civic Improvement in Hamilton}

British town planner Thomas Adams introduced Hamilton to the benefits of civic improvement through a presentation on city planning in 1915. Adams contended that Hamilton was well situated to become one of the greatest cities in Canada, but only if citizens and city council alike would acknowledge the natural and economic value held by their city:

The root of a city's existence is its industries ... Town Planning depends largely on what the town exists for. Hamilton, for example, needs to consider its industrial and manufacturing interests ... The smaller the town the greater the need for future planning. It is open to Hamilton to do many things in this respect which Toronto and Montreal are unable to do because of having reached such a point in population and development, that changes are almost impossible. ${ }^{3}$

Speaking in the context of the First World War, Adams also accounted for the cost of civic improvement, urging Hamilton residents to consider future fiscal rewards despite the encumbrance of supplying tax money for beautification projects:

Town planning is not a suggestion to spend more, but to spend more wisely. It is not for the purpose of interfering with private rights, but to create a realization of future needs and responsibility. Town planning means the cooperation of adjoining municipalities and land owners, and it 
is justified on the basis of human life, improved public health, better citizenship, more than on the basis of finance. ${ }^{4}$

Adams' speech was followed by a resolution implementing the Town Planning Board (TPB) of Hamilton. ${ }^{5}$ Among the first members of the TPB was Hamilton resident J.J. MacKay, ${ }^{6}$ whose membership is especially notable because of his early vision for "Hamilton, the city beautiful." In 1932, the Hamilton Herald wrote that MacKay had been imagining Hamilton's civic appearance for over forty years:

It was while tramping through the ravines and over the hills north of the city limits that he dreamed of the future and the beautiful entrance that might be developed. His dream called him beyond the limits of an entrance, for he could see a chain of parks linked up by driveways that would give Hamilton a park boulevard system second to none on the continent. $^{8}$

MacKay's vision for Hamilton was an early example of the civic pride that inspired beautification projects across North America. Indeed, the Hamilton Herald shared MacKay's sentiments in the news item, "How Hamilton Might Become City Beautiful." The entry emphasized Noulan Cauchon's 1917 sojourn in Hamilton: "His eye for the beautiful in nature has been attracted by the many supreme natural advantages of Hamilton ... He says there is no panoramic view elsewhere in Canada superior to it."9 Cauchon, like Thomas Adams two years earlier, also urged Hamiltonians to pursue beautification for its economic benefits:

There's an economic value in beauty ... and here's a beauty stretch that no other place possesses - not on this continent anyway ... Hamilton has many places of superb beauty. If the people here make the most of these places, they will prove of great financial value to the city. Tourists from everywhere can be attracted here to see them. ${ }^{10}$

One of the first occasions of town planning in Hamilton occurred in 1917, in association with Noulan Cauchon's visit. Following a construction surge in 1913 , 
Hamilton faced a series of circulation and sanitation issues associated with exponential urban growth. One particular concern was the impediment that the Toronto, Hamilton, \& Buffalo Rail Line was posing to the city's infrastructure and beautification." The final result was that in 1917 the city was obliged to commission non-resident professionals to assess the Hamilton rail situation. The position was given to Cauchon and William Francis Tye, former chief engineer of the Canadian Pacific Railway. By 1917, Cauchon was considered "Canada's foremost proponent of the relatively new field of town planning," 12 and his advice on the dire rail conditions in Hamilton was considered indispensable. As Tye had stated: "Hamilton was at the parting of the ways, and they should now plan for a large city if they were going to have one."13

Cauchon's series of reports from 1917 to 1919 effectively outlined practicable town planning for Hamilton:

Town planning is the science and art of controlling 'use and development of land' ... The past - replanning that which is already developed, yet through deterioration, fire or progress is undergoing more or less rapid and continuous conversion. The present - planning the course of inherent growth, local improvement to satisfy current expansion. The future planning with vision and with such foresight as the shadow of coming events may warrant..$^{14}$

Cauchon and Tye's first report was titled The Railway Situation in Hamilton,

Ontario and was finished in July of 1917 . Its primary recommendation was that train traffic be removed from residential areas and relocated to the eastern region of the city. The preponderance of train congestion would be removed to a double track at Hamilton's northern boundary, along the waterfront of Lake Ontario. An underground track for trains traveling within the city would also be implemented. ${ }^{15}$ Furthermore, Cauchon and Tye advised: "All the railways now and hereafter should use one common right-of-way 
through the city of Hamilton [and] ... there should be one union station up town.",16

Noting particularly the congestion on Ferguson Avenue, the report urged the amelioration of the rail lines for the sake of coal and munitions transport. ${ }^{17}$ The recommendations made by Cauchon and Tye were deemed costly, yet generally they were met with satisfaction by city officials and the media. ${ }^{18}$

Within two years Cauchon produced an additional pair of assessments for Hamilton which were commissioned by the TPB: the Reconnaissance Report on Development of Hamilton, Ontario (October 1917); and Report on Mountain Highways of Hamilton, Ontario (March 1919). The Reconnaissance Report was described by Cauchon as "a reconnaissance of those general conditions prevailing in Hamilton and throughout the areas surrounding it which will, in the nature of things and the course of time, evolve the greater Hamilton of the future."19 Cauchon based the comprehensive planning ideology featured in the Reconnaissance Report on the philosophy of King Solomon, who stated: "Where there is no vision the people perish." ${ }^{20}$ In accordance with Solomon, Cauchon maintained that proper town planning would allow Hamilton to flourish.

Contemporary scholars have summarized the Reconnaissance Report as a "farreaching document, ${ }^{, 21}$ and indeed Cauchon sought an all-encompassing strategy for Hamilton:

The Reconnaissance Report on the development of Hamilton District ... may cover more ground than you [City Council] have anticipated. A City however cannot live unto itself; it is an integral part of the larger life of a Nation ... Therefore it has been thought advisable to treat of development and planning on the broadest base of natural and economic law. ${ }^{22}$

The prime recommendation of the Reconnaissance Report comprised the construction of a monumental, colonnaded civic axis in Hamilton's downtown core. It 
was designed to trace the width of the city from the waterfront to the edge of the escarpment and terminate in a Grecian-style amphitheatre (Fig. 35). ${ }^{23}$ Cauchon intended that this long-term project would emulate those undertaken in parts of great European cities, including St. Peter's Square in Rome, ${ }^{24}$ while the amphitheatre overtly referenced the authority and nobility of antiquity. The amphitheatre was also part of a proposed war memorial honouring Hamilton soldiers from the First World War. Cauchon wrote:

"Hollowed from the mountain rim, fitting and decorative, [the amphitheatre] would seem an ideal war memorial, a feature for crowning the civic axis of Hamilton and heralding the lofty idealism of her sons." 25 Neither the civic axis nor the amphitheatre was built.

The civic axis emulates the Haussmannization of Paris, notably in its restrictions on building height ${ }^{26}$ and its use of man-made parks to ameliorate urban health. Cauchon compared Hamilton's civic axis to illustrious Parisian streets: "Complementary to the theatre seated on high in the park would be the boulevard, unrolling like a carpet from its feet towards the 'Traffic Circle and the railway station, a 'Champs Elysees' inviting the busy throng to turn towards the park and its mountain shrines. ${ }^{, 27}$ This facsimile, Cauchon believed, would inspire civic pride and cultural philanthropy of the highest magnitude. As he prophesized: "Would not the fires of enthusiasm be kindled in old and in young as they sat in the semi-circle above the city of their choice, sweeping their gaze from the sunsets of Dundas Valley over the city, the harbor, the hills and the broad expanse of Lake Ontario?"28 Cauchon thus capitalized on the connection with revered cities to advocate progress within Hamilton:

A people need to sense the fullness of real life and activity and to develop every latent talent and energy given them if they aspire to the fitness of survival and the ascendancy of being ... Are not such cities as London, 
Paris and New York, the centres of wealth and culture which they are because of their vast production and their lively contact with world-wide activities; seething crucibles of intellect that attract and refine genius in art, in science and in achievement? $?^{29}$

Cauchon's research for his three reports led him to conclude that a series of roads was needed to connect Hamilton's downtown core with the "fresh air and inspirational vistas" located on the mountain brow (Fig. 36) ${ }^{30}$ In the introduction to the Report on Mountain Highways, Cauchon recorded the project's purpose as "enabling Mountain Top suburban development and incidental park access."31 Cauchon's first reference to the Mountain Face Park appeared in the 1917 Reconnaissance Report, in which he characterized the land as one of "three unrivalled features of health asset and of spectacular beauty - jewels in the gift of nature awaiting acknowledgment by the hand of man." 32 He recommended that along with Mountain Face Park, the Causeway and Beach parklands should be developed to extend recreation venues in Hamilton. Cauchon wrote that recreation, "by stimulating the joy of living, is elemental in fostering survival, is economic, not wanton, ${ }^{, 33}$ and raised the subject of comprehensive planning in relation to the development of parks: "There is a particular lack of broadly distributed playgrounds and of small breathing spots [in Hamilton] ... in short, deficiency of neighborhood centres and a loss of what that provision accomplishes. The remedy is a process of time and careful calculation dependent on comprehensive planning. ${ }^{34}$

Cauchon abided by the theory that the city is an organism, a view that was in ascendance with town planners and landscape architects in North America (see Chapter One):

A city is an organism - a very complex and sensitive one - by physical analogy any disability in the freedom of its functional activities reveals 
itself forthwith in swoolen [swollen] values, failing sight, distressed breathing, depressed vitality, poor health ... Congestion is the economic cause of much poverty, disease and degradation. It can be dealt with by enlightened control of the 'use and development of land,' reversing the parasitic process of its nourishment. ${ }^{35}$

Cauchon's concentration on the organic nature of the city was timely, as it foreshadowed the authority that the City Beautiful movement would have in Hamilton. In 1924 the Hamilton Herald endorsed Cauchon's pursuit of beautification through an editorial titled "Forward, Hamilton!" that linked Hamilton with the City Beautiful:

Hamilton, the city beautiful. Let that be our watchword, and in the impulse of the wish is born the will to do, the support to put constructive vision into practical form. And, while we are strenuously carrying on the things of material purport, let us aim to further enrich our city by cultivating those of the spirit, the things of art, culture, faith and science. All this we can do, for the potentialities of Hamilton are immense. The realization rests with its citizens. ${ }^{36}$

The Herald editorial and the sustained wishes of citizens such as J.J. MacKay point to the authority of civic pride in the city. Indeed, the Herald substantiated this fact: "With new activity will come new enthusiasm, new civic interest, new pride in Hamilton. Now, therefore, is the time to launch this movement in all earnestness for the sake of a better Hamilton, so that it will have a keener edge for its association with a quickened economic pulse." ${ }^{37}$ Further, "it is not the individual effort that counts, it is the community effort. The part of the individual is co-operation. The inspiration that will effect this cooperation is civic pride. ${ }^{, 38}$

As renowned Canadian architect and city planning advocate Cecil Scott Burgess (1870-1971) argued about all Canadian cities: "The basis of civic pride must be interest in our town; interest in all the activities of all the people." 39 Burgess also outlined three provisions for a successful city: "Its people should be healthy, happy, and intelligent. 
Without these, a city cannot be a good place to live in - with them it cannot be a bad place. These three points can be put under one word 'health': health of body, of sentiment, and of intellect." 40 These categorizations reflect the improvements to beauty, edification, and circulation pursued by reformists in Hamilton. Having explored the impact that Noulan Cauchon had on Hamilton, and the receptiveness of the citizens to his recommendation, this chapter now turns to a discussion of Cauchon's theories put into practice by a proactive government body.

\section{Early Improvements: The Board of Parks Management and Beautification}

Beautification was made possible in Hamilton through the work of the Board of Parks Management (BPM) in the 1920s and 1930s. The BPM was instigated in 1920, under the Ontario Public Parks Act's proviso that a municipal park network had to be governed by a citizen board. ${ }^{41}$ Granted the ability to function independently of City Council, the BPM luxuriated in the opportunity to conceive and implement large-scale (and concurrently long-term) park projects in Hamilton. ${ }^{42}$ In the early 1920 s, two progressive figures emerged from the BPM: Cecil V. Langs, BPM chairman from 1923 to 1949, and Thomas B. McQuesten, BPM chairman of the Works Committee from 1922 to $1948 .^{43}$ Despite Hamilton's comparatively low population of 122,500 in the 1920 s, Langs and McQuesten's period of co-leadership was marked by vast progress in the development of parks throughout the city. ${ }^{44}$

The BPM under McQuesten and Langs was enticed by the morality of the City Beautiful movement then permeating North America. Indeed, the BPM members have been described as "visionaries who would design and build according to Beaux-Arts 
principles to create a Renaissance for Hamilton and for Canada that has never been equaled before or since ... When they praised the power of beauty, they were stating their belief in its capacity to shape human thought and behaviour." rejuvenate the city is comparable to the 'Canadian renaissance' later noted by their contemporary, architect John Lyle. ${ }^{46}$

Following the inception of the BPM the city was subjected to a series of park developments inspired by Noulan Cauchon's 1917 Reconnaissance Report, which argued for the value of public parks in Hamilton. ${ }^{47}$ A significant portion of the Reconnaissance Report was devoted to Cauchon's study of aesthetics, in which he allied beauty with truth: "Truth is the absolute beautiful. Art is the simple and refined outward expression of inherent truth. The function of art is to beautify the manifestation of truth." ${ }^{48}$ Cauchon expanded his discussion by stating that commercialism was a hindrance to truth: "Commercialized art is to aesthetics as commercialized vice is to ethics - a defilement.",49 Parks surpassing twenty in number were implemented by the BPM from 1922 to 1948, not including Royal Botanical Gardens and the significant renovations to the city's northwestern entrance (see next section). ${ }^{50}$ One of the earliest and most extensive park projects undertaken in Hamilton was the improvement of the 64-acre Gage Park property in the city's east end. When the BPM acquired the Gage family property in 1917 at a cost of $\$ 320,000$, it immediately recommended that the land function as public recreation space. $^{51}$ Landscape architect Howard Dunington-Grubb was appointed in 1924 to complete the planting at the site. ${ }^{52}$ Dunington-Grubb was an acquaintance of Noulan Cauchon's, ${ }^{53}$ and became one of the principal landscape architects in Hamilton's beautification. 
The year 1924 also witnessed the exclusion of motor traffic from Gage

Park. An editorial in the Hamilton Spectator admonished the BPM for this decision:

The decision to close Gage park [sic] to vehicular traffic passeth understanding. It defeats what is patently the intent of the board - the attracting of people to the park. The motor car is not now the rich man's luxury and the poor man's dream. Do those members of the parks board realize that if they persist in this strange attitude they will debar from Gage park half of Hamilton's population and all of the tourists who pass through the city? ${ }^{54}$

Despite this negative publicity, within a few years Hamilton citizen Eugenia Gage presented a gift of $\$ 20,000$ to the BPM. The conditions of the donation included the erection of a memorial in the park to honour her father, Robert Russell Gage. ${ }^{55}$ The gift eventually took the form of a memorial fountain designed by John Lyle (Fig. 37). It was set against the scenery of the Hamilton Mountain, and was formally dedicated to Robert Russell and Hannah Jane Gage in 1927. Lyle intended that the fountain should complement the natural setting designed by Dunington-Grubb. ${ }^{56}$ It is the centerpiece of the park, standing ten metres high at the crest of a series of cascading dams punctuated by fountains (Fig. 38). Lyle's design included accommodation for sculpture, including a relief of dancing children designed by Florence Wyle and executed by Donald Cree (Fig. 39). ${ }^{57}$ The fountain was encircled by three-dimensional sculpture, including bronze turtles and ducks. These whimsical features indicate that Gage Park was designed with families and children in mind, ${ }^{58}$ and that it was thus intended to be an integral part of the urban experience. The fountain echoed the design of that at Gore Park in Hamilton, although later modifications included the removal of the drum featuring Wyle's relief sculpture. ${ }^{59}$

The fountain has been characterized as a "civic ornament ... [which] is a characteristic expression of the City Beautiful movement in the first three decades of the 
twentieth century." 60 Its design foreshadowed Lyle's formal garden at the

Parkwood Estate in Oshawa and the Dunington-Grubbs' Sunken Garden at McMaster

University (discussed below). Furthermore, Lyle's work at Gage Park received an award

for memorial design and garnered accolades from the Journal of the Royal Architectural

Institute of Canada in 1929:

Mr. Lyle has made the most of an opportunity rarely given an architect today of designing a fountain which is large enough to dominate a park. One may stand in pensive mood and gaze into the basin of the Gage Fountain and see reflected in the water all the spouting monstrosities in cast iron or terra cotta of thirty or forty years ago, and feel a certain pride in the achievement of our time. ${ }^{61}$

Upon completion, the beautified Gage Park embodied the foresight of the Board

of Parks Management, which was praised for its visualization of Hamilton:

That the members of the parks board have the vision needed to meet the growing demands of the city is exemplified by the energetic manner in which they are pushing forward with the scheme, which will when completed give rest and recreation to old and young, amid flower and rose garden and shrubbery, and from the stretching lawns they can recline and gaze upon the natural beauties of the mountain behind. ${ }^{62}$

A second mention of the BPM's influence two years later corroborates the mostly

positive reception the Board received from citizens of Hamilton:

If Hamilton does not soon possess a parks development worthy of the ambitious city, it will not be the fault of the parks board. The men who comprise this body are pressing forward, in the face of financial handicaps, with improvements and schemes for the betterment of the parks system. They advance slowly but surely, and order arises out of the disorder consequent upon creative work. This is well exemplified in Gage Park, where, through the piles of cinders and earth, something of the beauty of the plan in the mind of the designer is already visible. ${ }^{63}$ 
The success of the Gage Park undertaking encouraged the BPM to continue purchasing low-cost land for future development into parklands. ${ }^{64}$ As the above newspaper articles record, the Board's efforts were met with enthusiasm and praise in the city.

\section{Edification and Dissemination: Hamilton's Beautification Ethos}

The collaboration between BPM aesthetes Cecil V. Langs and Thomas

McQuesten enabled the flourishing of Gage Park in the 1920s. As a result of this success the BPM continued to amass parkland in Hamilton, a project that has been termed "an unrelenting search." ${ }^{65}$ Consequent beautification ventures undertaken as a result of the BPM's management included the relocation of McMaster University and the establishment of Hamilton's Royal Botanical Gardens (RBG). McMaster and RBG were initially conceived as part of the redesign of Hamilton's northwestern entrance (see next section), but eventually evolved into projects distinct from the entrance.

In the first decade of the twentieth century, Hamilton was one of a few large Canadian cities (with a population nearing 75,000 in 1910) that did not possess an important post-secondary institution. At a time when Hamilton "citizens could point with pride to the new industries enticed to the community, including the merger known as the Steel Company of Canada," it was not surprising that "local McMaster alumni and some bumptious undergraduates from the 'Ambitious City' began lauding it as a worthy university site and a possible new location for their alma mater. ${ }^{966}$ The University was at that time located in Toronto. In the summer of 1928 over $\$ 525,000$ was donated to the University's relocation fund by Hamilton citizens, affluent and underprivileged alike, and 
by large-scale corporations. ${ }^{67}$ This range of contributors denotes the city-wide desire to attract a university to Hamilton.

The Hamilton campus of McMaster University was selected in 1927 as a result of an agreement between the Board of Parks Management, the University, Westdale Properties Ltd., the City of Hamilton, and the Hamilton Street Railway. The relocation was agreed to on 11 September, $1928 .^{68}$ The official groundbreaking occurred at a celebration on 23 October, $1928,{ }^{69}$ and the campus officially opened for study on 15 November, $1930 .^{70}$ Praise for McMaster continued long after construction was completed, particularly in one newspaper that called the relocation "one of the most progressive things ever done in the history of the city." 71

A large deciding factor in the relocation had been the additional availability of land in the Westdale suburb adjacent to the campus (Fig. 40). ${ }^{72}$ The hamlet of Westdale was advantageous because it was large enough to allow the University to expand outward in the future. ${ }^{73}$ Geographically the hamlet linked the campus with Westdale Park (later incorporated into RBG), while ideologically it was allied with the beautification and edification approach of the future botanical garden (see below).

Partisanship played a heavy role in the selection of architects and builders for the campus. Although initially a Hamilton architect was recommended, Chancellor Howard P. Whidden instead chose William Lyon Somerville of Toronto. To appease the Baptists, who formed a significant portion of the University's financial foundation, architects J. Francis Brown and Son were added to Somerville's project. Hamilton builder Joseph M. Pigott was employed to construct the campus, although some objected to his appointment as a result of his Roman Catholic faith. ${ }^{74}$ 
Despite their personal beliefs these professionals were suited to the rejuvenation of Hamilton then underway. William Lyon Somerville was involved in the Ontario Association of Architects and the professionalization of Canadian architecture, and in publicizing comprehensive design through his role in the Biennial Exhibitions of Architecture and the Allied Arts. Joseph Pigott, meanwhile, was outspoken on the necessity of civic beautification, as evidenced by a published essay of 1932 , when he was president of the Hamilton Chamber of Commerce:

When we first visit a city I believe our first impressions obtain from the buildings and subsequent impressions from the planting and general layout ... Business buildings or down-town buildings are the principal measuring rod for the progress and development of our Canadian cities ... It is important that citizens of Hamilton or any city should bear in mind that as old buildings in their down-town district can be removed and monumental buildings take their place that not only is the city's progress definitely marked but as each of these buildings goes up the load on the home builder in the matter of taxation becomes easier. ${ }^{75}$

Combining financial returns with the desire to appear modern and civilized, Pigott implored Hamilton residents to pursue civic beautification.

The design for McMaster included five Gothic-inspired buildings: one residence each for men and women, a refectory, an arts and administration centre, and a science building. The original design of 1928 (Fig. 41) also included a large chapel that would have connected the arts and science buildings and, as Chancellor Whidden phrased it, acted as "a silent symbol of the place of true Religion in relation to the study and pursuit of truth as contained in the Arts and Sciences." $" 76$ This feature was cancelled for financial reasons. ${ }^{77}$

Howard and Lorrie Dunington-Grubb, chief landscape architects for the original McMaster design, successfully recommended that the five buildings of the final design be 
grouped together and placed in the naturally beautiful setting of the ravine at the rear of the campus (Fig. 42). ${ }^{78}$ The popular Gothic Revival style functioned as "a strong visual signal that an institution of higher learning had come to the city,"79 and with it, a vision of civilized life. The Dunington-Grubbs' cooperation complied with Noulan Cauchon's recommendation in the Reconnaissance Report of 1917: "[It is] a question of fitness to purpose, to site and of scale, all of which can hardly be determined for locality without knowing the part each is to play in a comprehensive whole." ${ }^{80}$ Accordingly, the foremost beautification project at McMaster was the Dunington-Grubbs' formal Sunken Garden, placed just inside the campus entrance (Fig. 43). It was built in lieu of a great court punctuated by a gazebo, which proved financially impracticable after $1929,{ }^{81}$ but was nonetheless successful in creating a beautified recreation space on campus.

McMaster further embodies the beautification ethos sought by the Hamilton BPM in that Board member Thomas McQuesten attempted to get the campus grounds provincially designated as isolated park and building zones. Favouring a zoning plan that would force the campus to expand outward rather than crowding inward, McQuesten even proposed that the BPM would be financially responsible for maintaining the parks within the campus, as long as McMaster did not build on these spaces. McQuesten's strategy, though temporarily successful and certainly ideologically grounded, was ultimately discounted when the Dunington-Grubbs' Sunken Garden was razed to provide room for a new medical centre in the $1960 \mathrm{~s}^{82}$

In keeping with comprehensive planning of the 1930s, the BPM soon turned its attention to cultivating a beautiful, yet functional garden within the city. When the plans for Royal Botanical Gardens were announced in 1930 an encomium appeared praising the 
BPM for the expediency of the project: "Hamilton has the good fortune, under our excellent Parks Committee, to be the second city in Ontario to have a real Botanic Garden laid out as part of its civic activities ... [and] there is no reason why in time it should not become one of the finest gardens in the world.." ${ }^{83}$ This praise was matched in the city, where enthusiasm for the royally sanctioned botanical garden was mounting feverishly, especially in conjunction with the transfer of McMaster. The acclaim continued:

The climate of Hamilton is singularly well adapted to the development of a botanical garden, and in due time an arboretum may be added to the design. In connection with McMaster University, the existence of a Botanical Garden will be of real scientific value to the students. There are, of course, climatic limitations to every country and district, and while, for example, we may not be able to cultivate certain varieties of plants that flourish in Vancouver, there is probably no part of Canada besides in which such a wide range of plants can be acclimatized and kept in perfection as in Hamilton. ${ }^{84}$

The impetus behind Hamilton's Royal Botanical Gardens was part of the BPM's wish to expand existing parks through the acquisition of neighbouring plots of land ${ }^{85}$ Of primary importance to the RBG project was the purchase of land in Cootes Paradise, a wetland on the northwestern periphery of the city. Acquiring this property became the goal of the BPM as early as 1924, and was realized in 1927 when 258 acres of land and 119.5 acres of water were turned over to the Board. This attainment was a "coup for the Parks Board [and] was the starting point for acquisition of lands which would become the first component of Royal Botanical Gardens., ${ }^{, 86}$ By 1947, RBG possessed nearly 1,600 acres of land, a veritable "'botanical bonanza' ... ranging from formal ornamental gardens to undeveloped marsh and woods. ${ }^{987}$

The first cultivated RBG location was the Rock Garden, built over a former quarry and begun just one week after the October 1929 crash of the stock market. ${ }^{88}$ The 
garden was designed by landscape architect Carl Borgstrom and executed in conjunction with K.M. Broman. ${ }^{89}$ Broman was Superintendent of Aboriculture at Niagara Falls, and held considerable influence with the BPM.$^{90}$ According to the Hamilton Spectator,

With its natural picturesque setting of water and wooded slopes, the site for Hamilton's botanical gardens is the finest in the world in the opinion of K.M. Broman, superintendent of aboriculture, Niagara Falls parks commission. Mr. Broman, a native of Sweden, has seen botanical gardens in most of the countries of the world and speaks with authority. In a recent visit to the land lying along Dundas marsh, behind McMaster University at the western entrance of the city, he was very much impressed with the scenic beauty and possibilities of development. The official has strongly advised that the rich endowment of nature be not disturbed and during an interesting interview emphasized that in planning for the future, those responsible for the care of the garden should try to follow the pattern of nature, rather than change it. ${ }^{91}$

Despite the success of the Rock Garden as the triumph of $\mathrm{RBG}^{92}$ there was little mention of the garden in the press following construction. Publicity was limited to newspaper articles, including one entitled "Rock Garden," which contained little more than a prosaic reiteration of facts about its construction.${ }^{93}$ However, the Rock Garden embodies the beautification ideology of civic art: a disused, abandoned space was transformed into a beautiful, organic public recreation area (Fig. 44). In this way the garden, conceived as a natural space that could morally inspire visitors, was compatible with the rejuvenation philosophy of the City Beautiful movement.

A second early RBG undertaking was Hendrie Park. After vying for the grounds as early as 1924, the BPM saw its vision for a large park brought to fruition in 1931, when George Hendrie donated the 122-acre Valley Farm property in commemoration of his family. According to the Hamilton Herald, 
The property, which had always been recognized as ideal for park purposes, owing to its location on the border of the city and its natural beauty, has been purchased from the Hendrie estate by George M. Hendrie, who offered it to the city with practically no restrictions. He only asked that the city or parks board provide a suitable entrance from the Toronto-Hamilton highway, name it Hendrie Park, in honor of his father and brothers, and retain it in perpetuity for park purposes and for the free use of the general public, taking the necessary steps to preserve the bird and animal life and also the trees and creeks in their natural state. ${ }^{94}$

As one of the terms set out by George Hendrie, the entrance to the park was to be formalized with a set of ornate wrought iron gates made by Fred Flatman in 1931 (Fig.

45). However, the deepening financial crisis in the 1930s and the significant redevelopment already underway at the Rock Garden, as well as the campus of McMaster University temporarily stalled the project. It remained in abeyance until 1938, when John Lyle submitted a proposal to situate the gated entrance. ${ }^{95}$ However, because of the imminent Second World War, the gates remained uninstalled until 1953 and development on the Valley Farm lands would only begin in the 1960s. ${ }^{96}$

Despite the slow pace of improvements to Royal Botanical Gardens lands in the 1930s, the Board of Parks Management's ability to acquire property at little to no expense is commendable, especially as the new gardens played a significant role in establishing a connection between McMaster University and RBG. The campus was conceived with extensive landscaping, and the first educational partnership between McMaster and RBG appeared in the form of a 1932 study of the woodlands situated on RBG grounds. ${ }^{97}$ 
Circulation: Enhanced Roadways and Tourism

"It is most fitting that a beautiful historic location should have in its midst a beautiful bridge, and this, I am sure, has been accomplished." 98

- Hamilton Spectator, 1932

One of the foremost improvements to Hamilton's organic beauty in the 1920 s and the 1930s was the remodeling of the city's northwestern entrance on York Street: an undertaking combining beautification with the kind of practical impact (the improvement of traffic circulation) sought by both the City Beautiful and the City Scientific movements. The project began as a nation-wide competition hosted by the Board of Parks Management. The northwestern entrance competition was significant not only for its improvements to the natural beauty of the city, but also for the attendant projects that were necessitated or brought about by it as of 1926. In addition to the Rock Garden at RBG, these included a new High-Level Bridge, significant landscape refurbishments, and the construction of the Queen Elizabeth Way.

The competition for the northwestern entrance was announced in November of 1927. University of Toronto architecture professor Eric Arthur originated the idea, although it was ultimately sponsored by the BPM. In 1926, Hamilton city council had appointed the BPM as custodians of the lands along York Street and the High Level Road, as well as "other lands to be acquired for a future beautification project for this entrance." 999 By the end of the competition (in April of 1928) twelve proposals had been submitted. Although the jury (consisting of Eric Arthur, Hamilton architect W. P. Witton, and Toronto city surveyor T.D. LeMay) selected three finalists, the BPM had stipulated that it could alter any features it felt were inconsistent with their vision for the northwestern entrance. As the Hamilton Spectator documented, "the parks board reserved 
the right to use the best features of each plan in its development, planning as it did to make the entrance, "the most beautiful in [North] America.",100

The three finalists were: landscape architects Wilson, Bunnell and Borgstrom; landscape architects Howard and Lorrie Dunington-Grubb; and architect John Lyle. The Dunington-Grubbs and Lyle were the same professionals who had worked with the BPM on numerous earlier projects, including Gage Park, the Rock Garden, and the McMaster University campus. Wilson, Bunnell and Borgstrom's design (Fig. 46) won because it suggested that the grade of the highway be matched to that of a nearby bridge, although the jurors noted a few deficiencies: "[The plan] lacks some few features more developed by other competitors and is not impressive in its architectural design, but is outstanding in its planting and uniform development of the whole area and general conception of the purpose of the competition." 101 The designs submitted for the entrance emulated the grandeur of the civic centre proposed by Noulan Cauchon over a decade earlier. Monumentality thus reigned supreme in the plans for Hamilton's refurbishment, although the passing of time would prove that most of these projects were fiscally unfeasible.

The centerpiece of the completed northwestern entrance became the new HighLevel Bridge, the final design of which was rendered by John Lyle (Fig. 47). Lyle's participation on yet another BPM project underscores the Board's proclivity to re-employ selected professionals on beautification projects. ${ }^{102}$ The result is a portfolio of civic art throughout Hamilton and the surrounding counties that is stylistically linked, thus creating a comprehensive aesthetic for the city and its environs.

Hamilton's old High-Level Bridge (built in 1896) was demolished in part because the increase in motor traffic had rendered the two-lane structure obsolete, and because the 
old bridge - designed for carriages rather than cars - was by 1929 in danger of collapse. ${ }^{103}$ In addition, as the Hamilton Herald remarked, "for many years it had been the 'bottle neck' into which traffic from many roads east and west poured with resulting slowing up. The crossing of the high level was a trial endured only with great patience by the Sunday afternoon motorist." 104 Once the new bridge was completed, the Herald added that the old bridge "did not in any way conform to the entrance beautification scheme."105 Ostensibly, city council could justify the high cost of rebuilding the bridge by citing increased motor traffic and safety concerns. Yet the need for a new bridge that harmonized with the beauty of the new northwestern entrance was also of paramount importance.

The old bridge was demolished in 1931 as part of Hamilton's Depression-era make-work program. ${ }^{106}$ The construction of the new northwestern entrance to the city became a government-regulated make-work program, as did a number of other beautification projects, yet:

The need for economy forced a reduction in the aesthetic qualities of the work such as the colonnades, the obelisk, and most of the buildings [planned for the new northwestern entrance]. The real task was to salvage as many of the essential elements of Borgstrom's schemes [for Hamilton, as possible] within the restricted scope of the relief plan. ${ }^{107}$

Notwithstanding many modifications to the original plan, the new High-Level Bridge remains today a quintessential example of Hamilton's endorsement of civic art in the 1920s and 1930s. Both beautiful and practical (Fig. 48), it was designed to awe visitors entering the city from the northwest, and the complementary landscaping and natural vistas in the same area only propelled this intention. As one newspaper article stated: "The new bridge will be the greatest of a series that carry traffic around the 
western end of the bay and a worthy addition to the western entrance beautification scheme." 108

Upon completion of the bridge in June of 1932 an animated crowd gathered for celebrations and dancing, ${ }^{109}$ demonstrating the extent of Hamilton's enthusiasm for this significant civic emblem in the context of the Great Depression. Within a few days encomiums praising the construction and design appeared in local newspapers:

The new bridge is a thing of massive beauty and rugged charm that particularly delights the understanding eye of the engineer and also brings joy to the aesthetic heart of the layman. It is an appropriate centerpiece to set off the myriad beauties of the northwestern entrance, one of the most beautiful entrances any city on this continent can boast. Indeed, it was with the idea of making the bridge conform to that scheme that John M. Lyle, Toronto, consulting engineer, drew the designs. That he succeeded admirably is enthusiastically attested by the thousands who have already admired the structure. ${ }^{110}$

The redesign of the northwestern entrance was concurrent with the requisite creation of a high-capacity roadway connecting Toronto to Niagara, by way of Hamilton. This project was first recommended by Noulan Cauchon in the 1917 Reconnaissance Report, alongside the redeveloped northwestern entrance. " Furthermore, the judging committee of the entrance competition also recommended the construction of just such a highway, on the grounds that "while general development and improvement of the site are necessary, an adequate and dignified highway is of paramount importance, and that the purpose is not only to advertise the city, but, also to provide enjoyment and pleasure for its citizens." 12 The result of these suggestions was the construction of a great improvement to infrastructure in southern Ontario: the Queen Elizabeth Way (QEW), completed in 1940. 
From the outset the QEW was conceived as a beautified public space that would enhance tourism by means of safe access to the natural scenery of southern Ontario. The QEW begot major technological innovations to the design of roadways, such as a continuous series of lamp standards (Fig. 49) and cloverleaf interchanges (Fig. 50). ${ }^{113}$ In addition, the QEW inspired reform to road construction in view of safety concerns, particularly with the burgeoning use of cars in the 1930 s. One such innovation was the division of two-way traffic by means of a grass median. Another was the provision that the highway would be as straight as possible, eliminating sharp turns and ensuring continuous movement of traffic. The QEW was also designed to control access to the highway. This was achieved by means of interchanges, which would introduce vehicles onto the highway in such a way as to reduce interruptions to the flow of traffic. $^{114}$

The QEW also joined with the North American parkway tradition: a practice comprising roads that "were designed to speed traffic into and out of cities, rather than between cities." 115 In his collaboration with Minister of Highways Thomas B. McQuesten, QEW head architect William Lyon Somerville incorporated beautiful, natural scenery into the experience of traveling the length of the roadway (Fig. 51). ${ }^{116}$ Somerville was determined to beautify the length of the QEW with plantings: "The thoroughfare was intended not just to move goods and people as quickly, effortlessly and safely as possible. It was also to be a parkway - a roadway that seemed to pass through an endless park bordered by trees and farm fields. Driving on this roadway was to be pleasant and relaxing, and a satisfying aesthetic experience."117 The QEW also drew on landscape traditions initiated by Frederick Law Olmsted, who had created a parkway 
system in Buffalo in the 1890 s. As Olmsted wrote, "a park road is pleasant by reason of that which adjoins it, or is open to contemplation from it."118

Thus despite the highly functional quality of the QEW, it also manifested the connection between beauty and utility sought by comprehensive city planners and civic art. $^{119}$ Through the medium of natural scenery, the QEW was a pleasurable passageway between regional landmarks, notably Niagara Falls and Royal Botanical Gardens. ${ }^{120}$ Furthermore, significant sculptural monuments demarcate both the Toronto and Niagara entrances to the roadway. The Niagara entrance is punctuated by the Henley Bridge at St. Catherines, which is flanked on either end by a stylized ship prow that was officially opened by a royal visit in June 1939 (Fig. 52). Likewise the Toronto access features a beaux-arts monument comprising a pillar guarded by an imperial British lion (Figs. 5354). ${ }^{121}$ The Lion Monument, featuring sculptural adornment by Frances Loring and Florence Wyle, became a milestone that has been referred to as "the finest piece of

architectural sculpture in the country."122 Somerville designed the Henley Bridge and the Lion Monument to complement the beauty of the highway, to enclose the beauty promised within the length of the highway, and, concurrently, to reference the beautification of the nearby cities.

\section{Hamilton, The City Beautiful}

Hamilton's commitment to beauty is clearly evident through the significant number of improvement projects undertaken as of 1915 . This is especially true in comparison to the slow pace of progress in other Canadian cities. For example, a 1929 Toronto Star Weekly article entitled "Hamilton Shows Toronto How" (Fig. 55) praised 
the Hamiltonians, who "have been long conspiring secretly to show Toronto how to construct stately portals and thresholds that will compel the speeding tourist to jam on his brakes and pause and look about him in awe and wonder." 123 This article particularly praised Hamilton's renovations to the northwestern entrance: “One of Hamilton's demonstrations of superior virtue is the art of planning noble entrances and gateways, putting its scenic assets into communal circulation." ${ }^{24}$ A Toronto-based magazine thus portrayed Hamilton as an outstanding example of effective and beautiful city planning. The city was credited with true civic art, promoted by a civic body and with a cohesive, comprehensive vision.

A JRAIC article of 1932 also substantiated Hamilton's claims to beauty over Toronto by critiquing the latter's civic appearance. In response to the question, "why is Toronto so ugly?" the author, P.W. Thompson, claimed that the substance of the city was constructed from 1870 to 1890 , "at a time when architecture was at its worst."125 In "Toronto's Heritage of Ugliness," Thompson explained that despite its current appearance Toronto did have the potential to be beautiful:

It is not the absence of fine buildings so much as the presence of bad ones that keeps Toronto from being, in its entirety, a beautiful city. The material for creating the ideal civic exterior is here ... If Toronto ever hopes to be a truly great city she must cleanse her streets of mean and debasing structures, so that her citizens may fully appreciate all those that are beautiful and fine. ${ }^{126}$

Unfortunately, Thompson's recommendation reflects the questionable features of Canadian city planning from 1910 to 1939 . In order to implement grandiose beautification projects, cities could be ruthless in removing so-called unpleasant or unsightly features. This was true of Hamilton, which incurred plenty of criticism for 
forcibly removing shanty dwellers from their homes along the harbour in the late $1930 \mathrm{~s},{ }^{127}$ destroying boathouses that had been in place for up to ten to fifteen years. ${ }^{128}$ The land that was acquired from the shantytown demolition was eventually appropriated by RBG and put to use as expanded natural sanctuaries. Although the eviction could certainly be judged unethical and unjustifiable in important ways, the popularity of city planning in the 1920 s and 1930 s, combined with the promised moral, aesthetic and financial rewards of urban renewal, convinced the public that such actions were acceptable. As Thompson, along with many fans of civic improvement reminded the public, "it seems a fairly reasonable conclusion that people who spend their lives among ugly buildings will ultimately develop an outlook in some measure different from people whose architectural surroundings are harmonious and beautiful."129 The city of Hamilton applied this argument to the promotion of civic beautification. The promised outcome was an urban utopia of sorts, where the interconnected virtues of morality, civic pride and beauty would be present in abundance.

Hamilton's civic art is exemplary of geographical regionalism, in that it epitomizes the ethos, and the geographical opportunities offered by a specific physical location, rather than an ideological region bound by economic, political or social similarities. As regionalism theorist William Westfall summarizes, "regional cultures responded to the process of development by attempting to preserve and legitimate their own local experience." ${ }^{130}$ In addition to improving edification and circulation, Westfall confirms that beautified public spaces were tantamount to regional expression, and a means of garnering civic pride and cultural philanthropy. Through a series of 
improvement projects that escalated in scale as the years progressed, Hamilton developed a civic philosophy that lobbied for the social, moral, and fiscal value of beauty. 


\section{Endnotes to Chapter Three}

1 “Thousands Witness Opening of Great New Bndge," Hamilton Spectator, June 18, 1932 HPL High Level Brıdge Scrapbook, 21-27 (R 62420971352 HIG v 1)

${ }^{2}$ Terpstra, $115-116$

${ }^{3}$ Remarks by Thomas Adams HPL Hamılton City Plannıng Scrapbook, 1 (R 711409713 H18 ha v 1)

${ }^{4}$ Ibid

${ }^{5}$ Ibid

6 "Town Plannıng," Hamilton Spectator, July 19, 1915 HPL Hamilton City Planning Scrapbook, 5 (R 711409713 H18 hav 1)

7 "Forward, Hamilton' A Herald Edıtorial," Hamilton Herald, May 17, 1924 HPL Hamilton City Plannıng Scrapbook, 8-14 (R 711409713 H18 hav 1)

8 "His Vision of 40 Years is Realızed," Hamilton Herald, June 16, 1932 HPL High Level Bridge Scrapbook, 15-19 (R 62420971352 HIG v 1)

9 "How Hamilton Might Become City Beautıful," Hamulton Herald, August 4, 1917

${ }^{10}$ Ibid

"John C Best, Thomas Baker McQuesten, Public Works, Politıcs, and Imagınation (Hamilton Corinth Press, 1991), 41

${ }^{12}$ Ibid , 42

13 “Raılway Proposals Fully Explained," Hamlton Herald, August 17, 1917

${ }^{14}$ Noulan Cauchon, Reconnalssance Report on Development of Hamilton, Ontarlo (1917), $5 \mathrm{HPL}$

${ }^{15}$ Best, 43

16 “Ralway Proposals Fully Explained," Hamilton Herald, August 17, 1917

${ }^{17}$ Ibid

${ }^{18}$ Best, 43

${ }^{19}$ Cauchon, Reconnalssance Report on Development of Hamulton, Ontarlo (1917), 1 HPL

${ }^{20}$ Ibid , 1

${ }^{21}$ Best, 48

${ }^{22}$ Cauchon, introduction to Reconnassance Report on Development of Hamilton, Ontai io (1917) HPL

${ }^{23}$ Ibld , 71 
${ }^{24}$ Best, 49

${ }^{25}$ Cauchon, Reconnalssance Report on Development of Hamilton, Ontarıo (1917), 72 HPL

${ }^{26}$ Cauchon's Reconnalssance Report is quite extensive in its notes for aesthetic regulations in Hamilton For example, in a section titled 'Public Buıldıngs,' Cauchon recommended "architectural control of bullding lines, string course, cornice and sky lıne, if it be hoped to attain fine street effects and preserve the prominence of public monuments" (86) This is but one example of the guidance that Cauchon offered in reference to standardızing civic art in Hamilton HPL

${ }^{27}$ Cauchon, Reconnaissance Report on Development of Hamilton, Ontario (1917), 72 HPL

${ }^{28}$ Ibld , $72-73$

${ }^{29}$ Ibid , 10-11

${ }^{30}$ Best, 49

${ }^{31}$ Noulan Cauchon, Report on Mountain Highways of Hamilton, Ontario (1919), 1 HPL

${ }^{32}$ Cauchon, Reconnatssance Report on Development of Hamilton, Ontario (1917), 55 HPL

${ }^{33}$ Ibid , 54

${ }^{4}$ Ibrd , 73

${ }^{35}$ Ibıd , 35

36 "Forward, Hamilton' A Herald Editonal," Hamilton Herald, May 17, 1924 HPL Hamilton City Planning Scrapbook, 8-14 (R 711409713 H18 hav 1)

${ }^{37}$ Ibid

${ }^{38}$ Cecil Scott Burgess, "Civic Pride," in Architecture, Town Planning and Communty, Selected Writungs and Public Talks by Cecll Burgess, 1909 1946, ed Donald G Wetherell (Edmonton University of Alberta Press, 2005), 119

${ }^{39}$ Ib1d , 120

${ }^{40}$ Ib1d , 120

${ }^{41}$ Leslıe Laking, Love, Sweat and Soll, A History of Royal Botanical Gardens from 1930 to 1981

(Hamılton Royal Botanıcal Gardens Auxılıary, 2006), 7

${ }^{4}$ Ibld , 7-8

${ }^{43} \mathrm{Jb}$ d , 8

${ }^{44}$ Ibıd , 8

${ }^{45}$ Mary J Anderson, Tragedy and Trlumph Ruby and Thomas B McQuesten (Dundas Tierceron Press, $2011), 166$ 


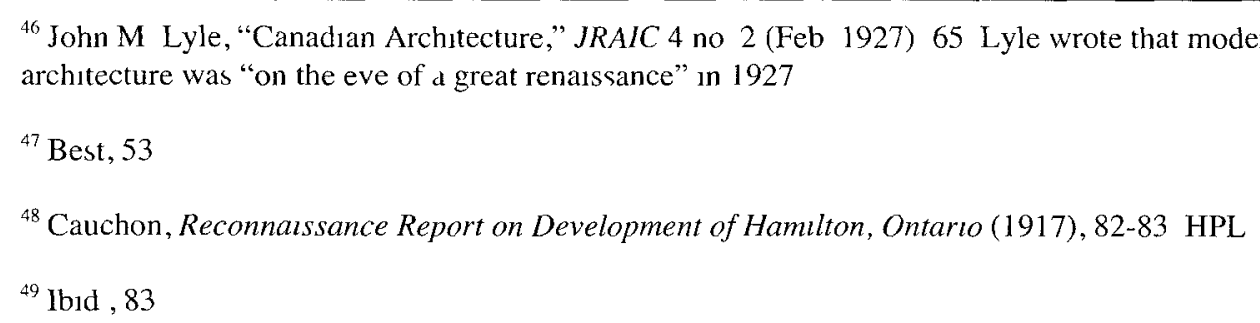

${ }^{50}$ Mary J Anderson has compiled a list of the most notable parks completed by the BPM during Thomas McQuesten's tenure as Chairman of the Works Committee (from 1922-1948) They include, in part Gage Park, La Salle Park, Bruce Park, Hendrie Park, Donohue Park, Inch Park, Dundurn Park, Victorıa Park, Kıng's Forest Park, and Chedoke Park (171)

51 "Gage Property Recommended for Park Use, Hamilton Spectator, Sept 19, 1917 HPL Gage Park Scrapbook, 1 (R712 50971352 GAG v 1)

52 "To Beautıfy Park," Hamlton Spectator, March 25, 1924 HPL Gage Park Scrapbook, 10 (R712 50971352 GAG v 1)

${ }^{53}$ Best, 54

34 “A Strange Rulıng," Hamilton Spectator, June 28, 1924 HPL Gage Park Scrapbook, 13 (R712 50971352 GAG v 1)

55 "Generous Gift to Park Board," Hamilton Spectator, June 1926 HPL Gage Park Scrapbook, 22 (R712 50971352 GAG v 1) John Best notes that Thomas McQuesten sought to rename Hamilton's parks after renowned historical figures He proposed to honour Sir Isaac Brock in this manner, a local hero from the Anglo-American war of 1812 However, this suggestion met with swift disapproval from the Gage family, and the origind name was retained (54)

\footnotetext{
${ }^{56}$ McArthur, 120

57 "Beautıful Memorıal Formally Dedicated," Hamilton Spectator, June 23, 1927 HPL Gage Park, 3234 Scrapbook (R712 50971352 GAG v 1) John Best remarks that Thomas McQuesten gathered a repertoire of artısts, architects, and landscape architects about hım Among them were John M Lyle, Willam Lyon Somerville, the husband and wife Dunington Grubb team, and sculptors Florence Wyle and Frances Lorıng (56) Indeed, the collaboratıve partnership of these professionals would mark a series of projects headed by McQuesten, as well as a number of works completed outside of his dominion

${ }^{58}$ Anderson, 177

${ }^{59}$ Very recently (2011) eftorts have been made to restore the Gage Park fountain to its orıgınal desıgn, including replacing the sculpted drum of the memorial Concurrently, the Hamilton Park s Board has been aimıng to restore the original landscape architecture of the Dunington Grubbs (Anderson, 177)

${ }^{63}$ Hunt, 99

${ }^{61}$ Eric Arthur, "Toronto Chapter Architectural Exhbition," JRAIC 6, no 3 (March 1929) 101

67"Gage Park now resplendent in Glory of Sprıng," Hamilton Spectator Aprıl 5, 1924 HPL Gage Park Scrapbook, 11 (R712 50971352 GAG v 1)
} 
63 "Lovely Garden is planned in East End Park," Hamulton Spectator, May 26, 1926 HPL Gage Park Scrapbook, 20-21 (R712 50971352 GAG v 1) Hamilton's industrial sector grew exponentially in the second half of the nineteenth century As a result, the city gave itself the moniker of the "Ambitious City," which was reflected in the extensive reformation undertaken in Hamilton in the first half of the twentieth century Indeed, Noulan Cauchon 1dentified Hamilton's ambition in his Reconnalssance Report of 1917 "[Hamilton,] rich in the fertility of its soll, nourished by abundant waters and a sunny clime, is further endowed with a gifted population, whose energy and ambition, industry and production, justify a glowing vision of its full realization of life" (1-2) HPL

${ }^{64}$ John Best notes that throughout the reign of Langs and McQuesten, the pair continuously searched for avallable land to convert into park spaces, "usıng their legal experience to engineer land acquisitions far in excess of what the BPM's meagre finances would normally have permitted," (53)

${ }^{65}$ Lakıng, 9

${ }^{66}$ Charles M Johnston, McMaster Untversity, Volume 2 The Early Years in Hamilton, 1930-1957

(Toronto University of Toronto Press, 1981), 6

${ }^{67}$ Ibid , 10

${ }^{68}$ Lakıng, 34-35

${ }^{69}$ See particularly "Turnıng the Sod," Hamilton Herald, Wednesday October 24, 1928 HPL McMaster Unıversity Scrapbook, 59 (R378 71352 MCM v 1) This editorial commends the relocation of McMaster to Hamılton "The ceremony of turnıng the first sod of McMaster yesterday betokens much for Hamilton It was an auspicious moment in the history of the city Gathered at the ceremony were many citizens of the first rank in mind and heart, and the city behind them had already shown its full-handed appreciation of the undertaking"

${ }^{70}$ See "McMaster Now Officially Open," Hamilton Herald. November 15, 1930 HPL McMaster Unıversity Scrapbook, 83 (R378 71352 MCM v 1)

71 "Silhouette Interviews Prominent Citızens - Leading Citızens Tell McMaster's Effect on City," Silhouette, Dec 15, 1931 HPL McMaster Unıversıty Scrapbook, 94 (R378 71352 MCM v 1)

${ }^{72}$ A newspaper article from 1923 comprises one of the first mentıons of McMaster in connection with the Westdale property Furthermore, it outlınes some early stıpulations for the campus plans that were drawn up "The Unıversıty and the board of parks management will at an early date work out unıtedly [sıc] a farreachıng and harmonious landscape scheme accordıng to agreements already sıgned The architects are preparıng bulding plans in relation to a comprehensive scheme for future development The general type of architecture is to be Collegiate-Gothıc " "Prepare Plans for McMaster in Wesidale," Hamilton Herald, Sept 22, 1923 HPL McMaster Unıversity Scrapbook, 8 (R378 71352 MCM $\vee 1)$

\footnotetext{
${ }^{73}$ Johnston, 7

${ }^{74}$ Ibrd , 18

${ }^{75}$ Joseph M Pıgott, "Civıc Beautıficatıon "JRAIC 9 no 7 (Jul 1932) 164

${ }^{76}$ Chancellor Whidden quoted at Johnston, 19

${ }^{77}$ Ibid , 19
} 
${ }^{78}$ Ibid , 19

${ }^{79}$ Ibid , 20

${ }^{80}$ Cauchon, Reconnalssance Report on Development of Hamilton, Ontarlo (1917), 85 HPL

${ }^{81}$ Johnston, 20-21

${ }^{82}$ Best, 58

83 “The Royal Botanıc Gardens," May 20, 1930 HPL Royal Botanical Gardens Scrapbook, 24a (R712 56 H1 82 V 1)

${ }^{84}$ Ibid

${ }^{85}$ Lakıng, 9 Lakıng documents the acquisition of Hendrie Farm in Aldershot (a region beyond Hamılton's city limits) as an example of such expansion The first plans for this expansion appeared in 1924, although the land was not bestowed to the city until 1931 The Hendrie lands became a large component of RBG

${ }^{86}$ Ibıd , 9

${ }^{87}$ Ken Ford, "1,600 Acres of Land Form Botanıcal Bonanza," Hamilton Spectator, May 28, 1947 HPL Royal Botanıcal Gardens Scrapbook, 102 (R712 56 H182 v 1)

${ }^{88}$ Laking, 24

${ }^{89} \mathrm{Ib}$ id, 25

${ }^{90}$ Mary J Anderson documented the convivial relatıonship between K M Broman and BPM Charman of the Works Committee, Thomas B McQuesten Besides working together on RBG as of 1945, the pair was connected through the Niagara Parks Commission (NPC) McQuesten headed the commission and Broman was responsible for the extensive landscape design at Niagara in the 1930s, as well as heading the NPC School for Apprentice Gardeners Based on his history of successful planning at the Rock Garden, and the work he completed for the NPC, Broman was appointed Superintendent of RBG in 1945 (297-300)

91 "City's Botanical Gardens Located in One of World's Finest Sites, Expert Says," Hamilton Spectator, Sept 19, 1942 HPL Royal Botanıcal Gardens Scrapbook, 62 (R712 56 H182 v 1)

${ }^{92}$ Laking notes "The Rock Garden became such a popular venue that it was, in fact, synonymous with Royal Botanical Gardens Few visitors were aware that there was anything else The other 1,400 acres that comprised RBG by the early 1940s were virtually ıgnored, except by naturalısts and firemen" (26)

93 "Rock Garden," Hamilton Herald, December 19, 1931 HPL Royal Botanıcal Gardens Scrapbook (R712 56 H182 v 1)

94 "Will Become One of Best in City," Hamlton Herald, Sept 25, 1931 HPL Royal Botanıcal Gardens Scrapbook, 24c (R712 56 H182 v 1)

${ }^{95}$ Lyle was appointed by George Hendrie to install the gates to the new RBG Park in 1932 Lyle had a history of atfiliation with the Hendrie famıly, partıcularly the park's namesake William Hendrie, for whom Lyle designed a house on Aberdeen Avenue in Hamilton in 1905 (McArthur, 51, 53) 
${ }^{96}$ Lakıng, 33-34

${ }^{97}$ For more information see "Survey Made of Botanıcal Gardens," Hamilton Herald, July 23, 1932 HPL Royal Botanical Gardens Scrapbook, 28 (R712 56 H182 v 1)

${ }^{98}$ Hamilton Controller Don McFarlane quoted in "Thousands Witness Openıng of Great New Bridge," Hamilton Spectator, June 18, 1932 HPL High Level Brıdge Scrapbook, 21-27 (R 62420971352 HIGv 1)

${ }^{99}$ Lakıng, 10

100 "Thousands Witness Opening of Great New Bridge," Hamllton Spectator, June 18, 1932 HPL High Level Bridge Scrapbook, 21-27 (R 62420971352 HIG v 1)

${ }^{101}$ Letter from Eric Arthur, W P Witton, and T D LeMay to C V Langs, Chairman of the Hamilton Board of Parks Management, reproduced in "Awards in the Competition for a North-Western Entrance to the City of Hamilton," JRAIC 5, no 4 (April 1928) 132-133

${ }^{102}$ Best, 56

103 "City Must Rebuld High Level Bridge," Hamiton Spectator, June 27, 1929 HPL High Level Brıdge Scrapbook, 3 (R 62420971352 HIG v 1)

104 "Development of Entrances to Hamılton Great Undertakıngs," Hamlton Herald, December 19, 1931 HPL High Level Bridge Scrapbook, 7-8 (R 62420971352 HIG v 1)

105 "New Bridge Fourth to Span Desjardıns Canal in 80 Years," Hamilon Herald, June 16, 1932 HPL High Level Brudge Scrapbook, 13-14 (R 62420971352 HIG v 1)

106 "Bridge Razıng to Start in September," Hamulton Herald, August 8, 1931 HPL High Level Bridge Scrapbook, 6 (R 62420971352 HIG v 1)

${ }^{107}$ Best, 61

108 "Development of Entrances to Hamilton Gredt Undertakıngs," Hamlton Herald, December 19, 1931 HPL High Level Bridge Scrapbook, 7-8 (R 62420971352 HIG v 1)

109 "Great Crowd Dances on Brıdge," Hamilton Herald, June 17, 1932 HPL High Level Bridge Scrapbook, 20 (R 62420971352 HIG v 1)

110 "New Bridge Fourth to Span Desjardins Canal in 80 Years," Hamulton Herald, June 16, 1932 HPL High Level Bridge Scrapbook, 13-14 (R 62420971352 HIG v 1)

"'Cauchon, Reconnatssance Report on Development of Hamulton, Ontario (1917), 74 HPL

112 Letter from Eric Arthur, W P Witton, and T D LeMay to C V Langs, Chairman of the Hamılton Board of Parks Management, reproduced in "Awards in the Competıtıon for a North-Western Entrance to the City of Hamilton," JRAIC 5, no 4 (April 1928) 132

${ }^{113}$ Anderson, 226

${ }^{114}$ Robert M Stamp, $Q E W$ Canada's First Superhighway (Erın Boston Mills Press, 1987), 20 
${ }^{115}$ Ibid , 12

${ }^{116}$ John C van Nostrand, "The Queen Elızabeth Way Public Utılıty Versus Public Space," Urban History Review/Revue d'histolre urbaine 7, no 2 (Oct, 1983) 4, 9

${ }^{117}$ Anderson, 224

${ }^{118}$ Olmsted quoted in van Nostrand, 4

${ }^{119}$ In 1 ts first manifestation the QEW was successful as a beautıfied parkway connecting three major citıes However, despite provisions for increasing motor traffic, the QEW has been subject to a series near contınuous expansions in its lifetime The result is that the pleasant parkway first imagined by Somerville and McQuesten has been replaced with a plainly utılitarian highway Most of the original landscaping has been lost, and the Lion Monument was moved to Sir Casimir Gzowskı Park in Toronto in 1975, out of context and concurrently out of mind The demise of the original QEW has been traced at length by John C van Nostrand in "The Queen Elızabeth Way Publıc Utılıty Versus Public Space" (1983)

${ }^{120}$ Anderson, 224 From approximately 1935 to 1941 Niagara Falls underwent beautification similar to that of Hamilton This was due to Thomas McQuesten, who was simultaneously a member of the Hamilton Board of Parks Management and the Niagara Parks Commıssion At Niagara, McQuesten implemented a series of civic art projects including the international Rambow Bridge (dedicated in 1939), a carllon, a triumphal arch and an amphitheatre beautıfied with Canadian sculpture and gardens (the Oakes Garden Theatre, completed in 1937 and featurıng landscapıng by the Dunıngton-Grubbs, architecture by Wıllıam Lyon Somerville, and sculpture by Elızabeth Wyn Wood, Frances Loring and Florence Wyle) The polıtıcs guidıng the Niagara projects are best recounted in Joan Coutu's triad of publications (including two published essays from 2009 and 2002, and an M A thesis from 1989)

${ }^{121}$ See Anderson, 225-228 The Royal Visit to commemorate the construction of the QEW was timely Occurring on June 7, 1939, (less than three month before the outbreak of World War Two) King George VI and Queen Elizabeth sanctified a project that strengthened relations between Canada and Britain Indeed, the namesake of Canada's first superhighway was the Queen herself, and Lorıng's sculpture on the base of the Lion Monument represented "the defiance of a beleaguered natıon," (Sisler at Stamp, 45)

${ }^{122}$ Rebecca Sisler quoted at Stamp, 45

${ }^{123}$ R C Reade, "Hamılton Shows Toronto How," Toronto Star Weekly Nov 16, 1929

${ }^{124} \mathrm{Ib} 3 \mathrm{~d}$

${ }^{125}$ P W Thompson, "Toronto's Hentage of Uglness," JRAIC 9, no 9 (Sept 1932) 212

${ }^{126}$ Ibid , 213

${ }^{127}$ Criticism of the BPM's tactics remains relevant to this day, particularly in the realm of contemporary scholarshıp For instance, the collaboratıon between Nancy B Bouchier and Ken Cruıshank in 'The War on the Squatters, 1920-1940 Hamilton's Boathouse Community and the Re Creation of Recreation on Burlıngton Bay" (2003), demonstrates the despite the success of City Beautıful work in Hamilton from 19151939 , many citizens suffered for the improvements

128 "Marsh Tenants Told to Vacate City Property," Hamılton Spectator May 11, 1936 HPL Royal Botanical Gardens Scrapbook, 35 (R712 56 H182 v 1)

${ }^{129}$ Thompson, 212 
${ }^{130}$ Willıam Westfall, "The Regional Patterns in Canada and Canadian Culture," in Perspectives on Regions and Regionalısm in Canada, ed Willım Westfall (Ottawa The Associatıon for Canadian Studies, 1983), 9. 


\section{Conclusion - Beauty is Not a Dirty Word}

The model of collaborative work that originated from comprehensive city planning inspired the application of civic art in cities across Canada. The sheer complexity of collaborative work has rendered this civic art amorphous and elusive, yet evidence of beautification across Canada proves that it was effectual. Collaboration permeated the fine arts, where alliances between professions led to inclusive civic art projects such as murals, public parks and gardens, and infrastructure improvements.

For the purpose of this thesis, the term 'civic art' has been broadened to include both aesthetic and utilitarian improvements in Canadian cities. The purpose of this was to consider what the discipline of civic art entailed when it was promoted by architects, engineers, artists and other professionals from approximately 1889 to 1939. As a result, this thesis has approached the topic of civic art from a series of angles, including its shared origins with the city planning phenomenon, the consequences of collaborative work for the fine arts, and a consideration of the application of civic art in a single city (Hamilton, Ontario). In an attempt to sketch the wide-range of civic art, this thesis has amalgamated a series of interdisciplinary topics. However, the comprehensive nature of civic art proves that there was an inherent connection between city planning and the fine arts, such as that outlined by Charles Mulford Robinson in Modern Civic Art; or, the City Made Beautiful. Collaboration, the preeminent feature of both comprehensive city planning and the allied arts, became the motivating force of civic art: progressive professionals worked together to promote their disciplines alongside the emerging field of Canadian civic art. 
Collaborative work in city planning resulted in the amalgamation of a series of approaches to urban beautification and improvement. For the purposes of this thesis these have been limited to the City Beautiful, the Social Gospel and Progressivism, and the City Scientific. Together these generate an inclusive overview of city planning, but they do not account for every improvement and beautification approach that appeared at the turn of the twentieth century. Further research into lesser-known Canadian city planning approaches would yield a fuller image of the character of the city planning movement in Canada. Furthermore, there is as yet no comprehensive study of all the beautification and improvement proposals that appeared across Canada by 1939 . Scholarship in this field would greatly benefit from a survey of the complete Canadian city planning proposals, which could draw clearer conclusions about the origins of the movement, shared aesthetic and ideological aims, and reasons for the demise of the phenomenon. This thesis constitutes a preliminary attempt to outline Canadian civic art but further research is needed, particularly as civic art reform is often examined through the lens of contemporary public art. Furthermore, the discussion of the allied arts in this thesis has been localized in Toronto, but the field deserves a much more comprehensive study. In the future research could be conducted on the proliferation of the allied arts in other Canadian cities, particularly in the Eastern and Western provinces.

Recently historic civic art and urban beautification have begun to receive scholarly attention in arrears. This may be due to the fact that the value of beauty is beginning to witness resurgence in contemporary society, particularly in light of concerns about conservation and sustainable living. The value of the natural environment and the positive benefits it engenders for society, a theory reinforced in North America through 
comprehensive planning, is entering mainstream principles. This is the conclusion that contemporary architect Richard Rogers reached when he stated: "Beauty is Not a Dirty Word." The benefits to be reaped from beautification are currently coming to the forefront of our collective social conscience. Rogers, echoing the sensibilities of the aesthetes who came before him, wrote that "the properties of solid and void, whether in buildings of public space, stimulate the imagination and lift the spirit. A building without beauty is not architecture but a construction, much as music without beauty is just noise." Indeed, Rogers bravely referenced the sacrifice society makes of beauty by acknowledging that it has become a 'dirty word' in contemporary society: "Architecture, one of the most visible aspects of public life, has been sacrificed to short-term public economies and private profit.." Furthermore, Rogers cited one of the principles of the city planning movement when he wrote: "It is now well-established that low-quality, ugly environments breed vandalism, crime, ill health and depression; conversely, good design encourages social well-being. The quality of our built environment remains a major political issue, even if it is an issue that for so long has not dared to speak its name." Rogers' contemporary argument about beauty has not been an isolated one. More recently Simon Jenkins of The Sunday Times corroborated that beauty is indeed considered a dirty word. Jenkins wrote: "The beauty of nature is plainly a salve to worldly cares, ${ }^{, 4}$ thus arguing that the ideology of comprehensive city planning was - and is - advantageous for Canadian society. While historically beauty was almost phased out of city planning, collaborative efforts proved that cities are the most efficient when they amalgamate beauty with utility. Thus the main tenet of civic art, that beauty is as necessary to Canadian cities as utility. 


\section{Endnotes to Conclusion}

\footnotetext{
1 Richard Rogers, "Beauty is Not A Dirty Word," Resurgence 207 (July-Aug 2001)

${ }^{2}$ Ibid

${ }^{3}$ lbid

${ }^{4}$ Simon Jenkıns, "Beauty is a Dirty Word," The Sunday Times, March 15, 2009
} 


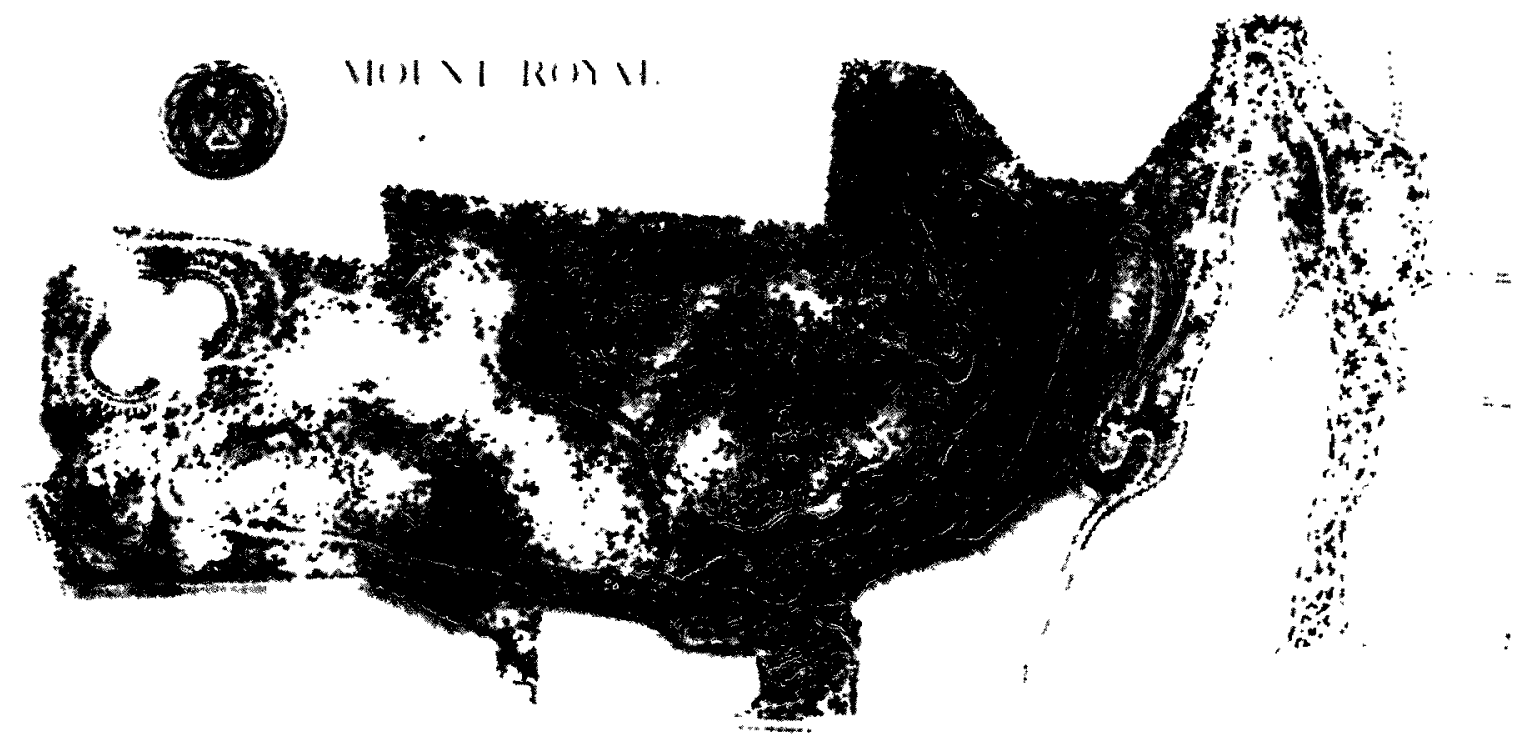

Fig. 1: Frederick Law Olmsted, Sr., Plan for Mount Royal (1881). 


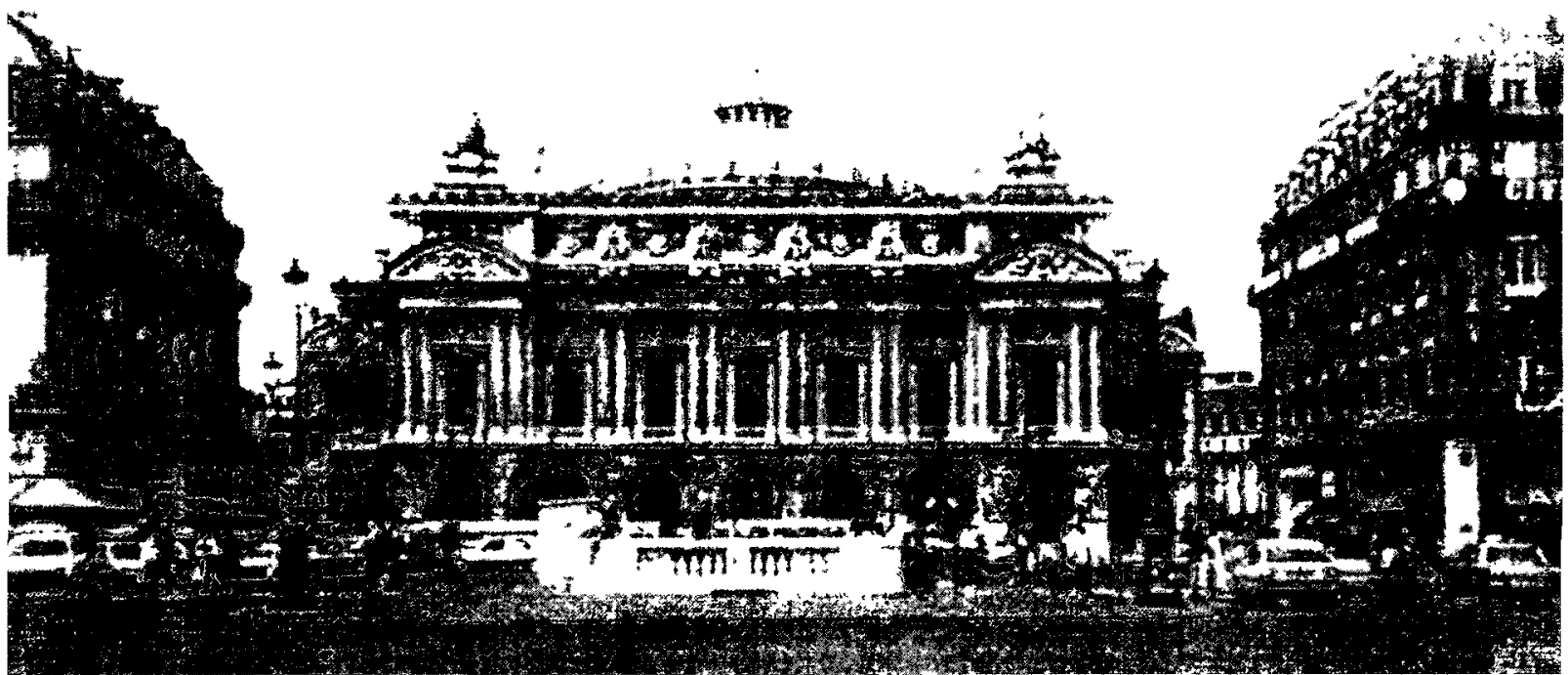

Fig. 2: Charles Garnier, facade of Paris Opéra House (1858-1872).

Photo Credit: Gilbert A. Stelter "Rethinking the Significance of the City Beautiful Idea," Urban Planning in a Changing World: The Twentieth Century Experience, ed. Robert Freestone (London: E \& FN Spon, 2000). 


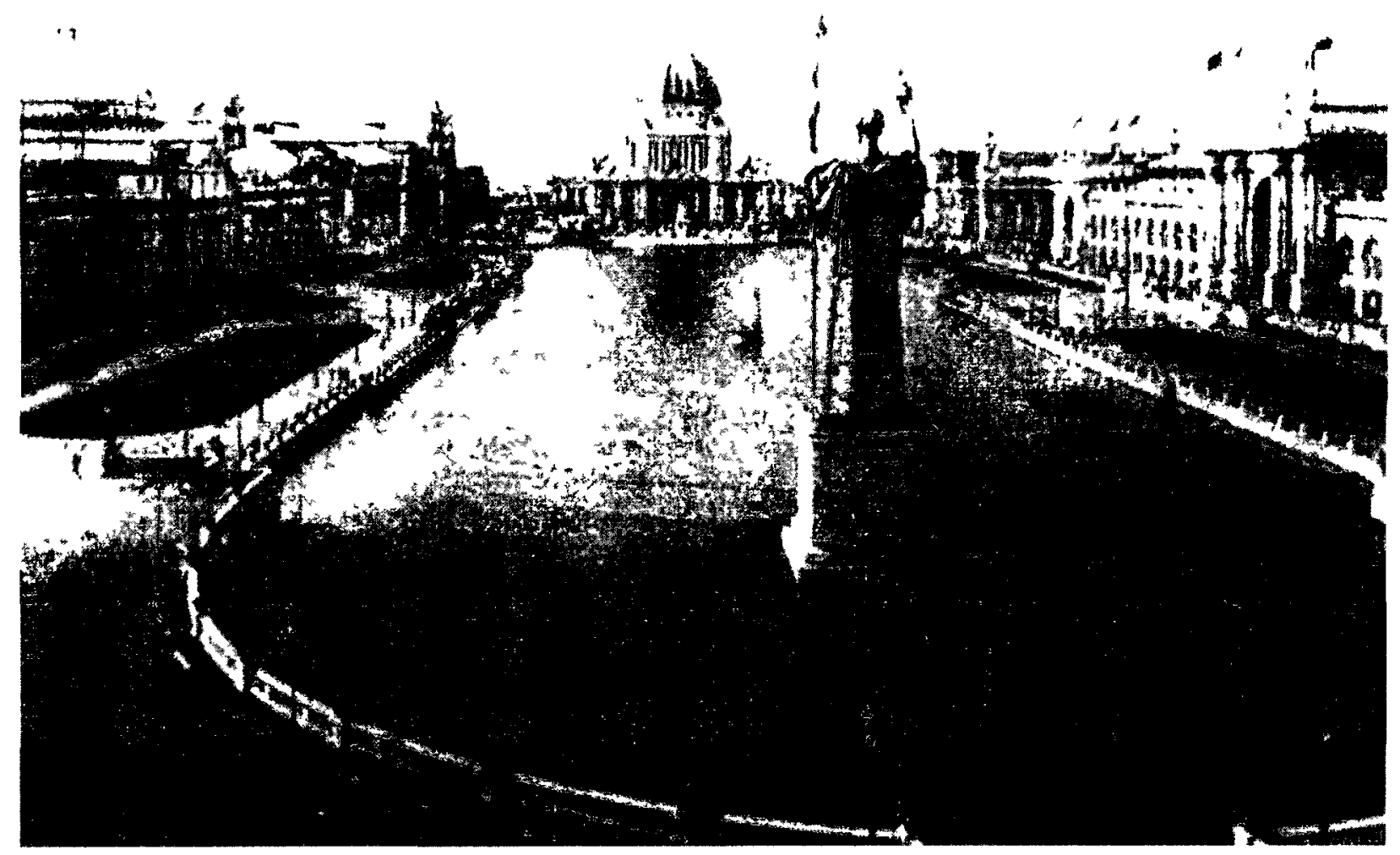

Fig. 3: City Beautıful inspired neo-classical buildings and sculpture at the Chicago World's Exposition (1893) Photo Credit: Gilbert A. Stelter "Rethinking the Significance of the City Beautiful Idea," Urban Planning in a Changing World· The Twentıeth Century Expertence, ed Robert Freestone (London E \& FN Spon, 2000) 


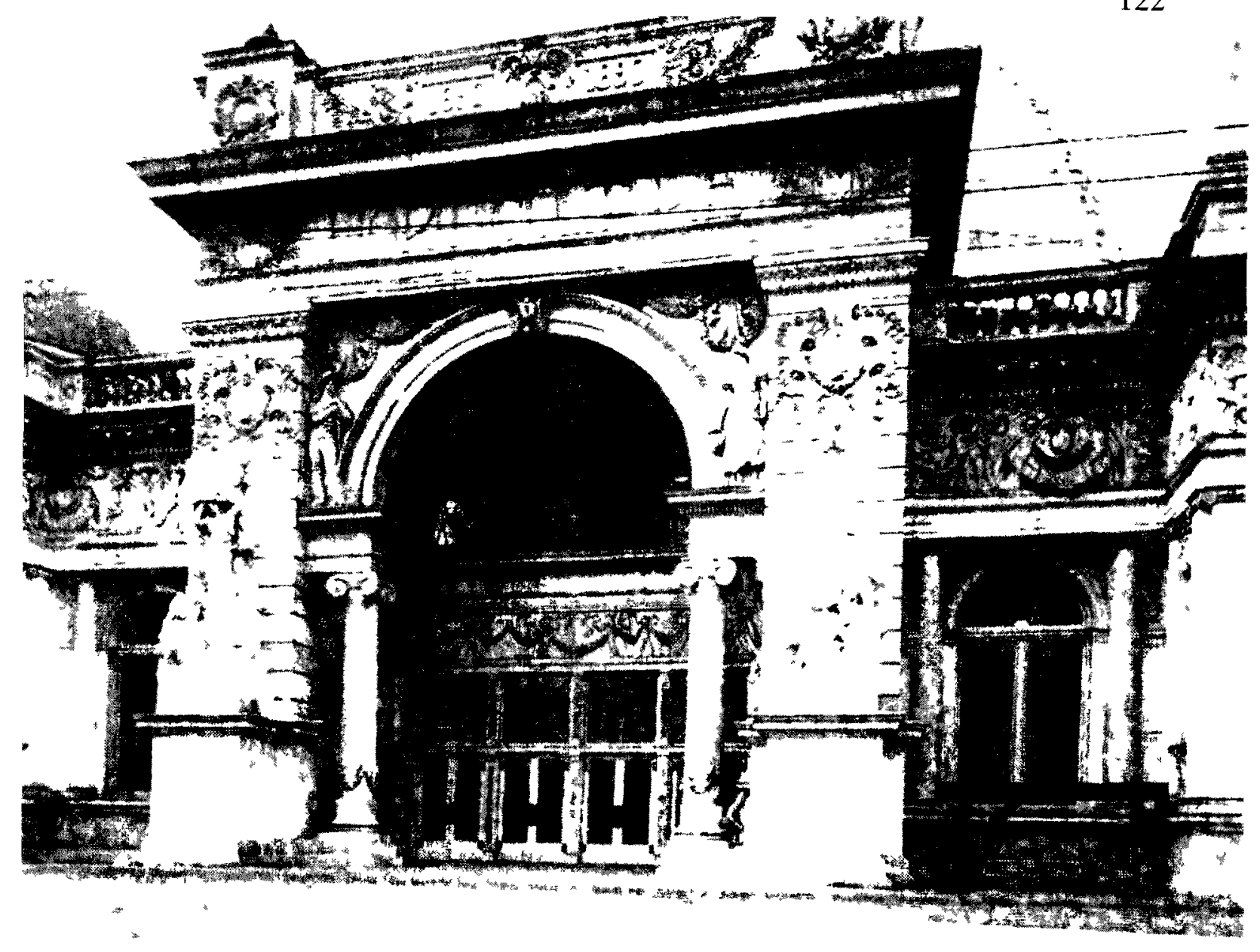

Fig. 4: Lorado Taft, sculptural adornment on the Horticultural Building at the 1893 Chicago World's Exposition, Sleep of Flowers and Awakening of Flowers. Photo Credit: Timothy Garvey, Public Sculptor, Lorado Taft and the Beautification of Chicago (Urbana: University of Illinois Press, 1988). 


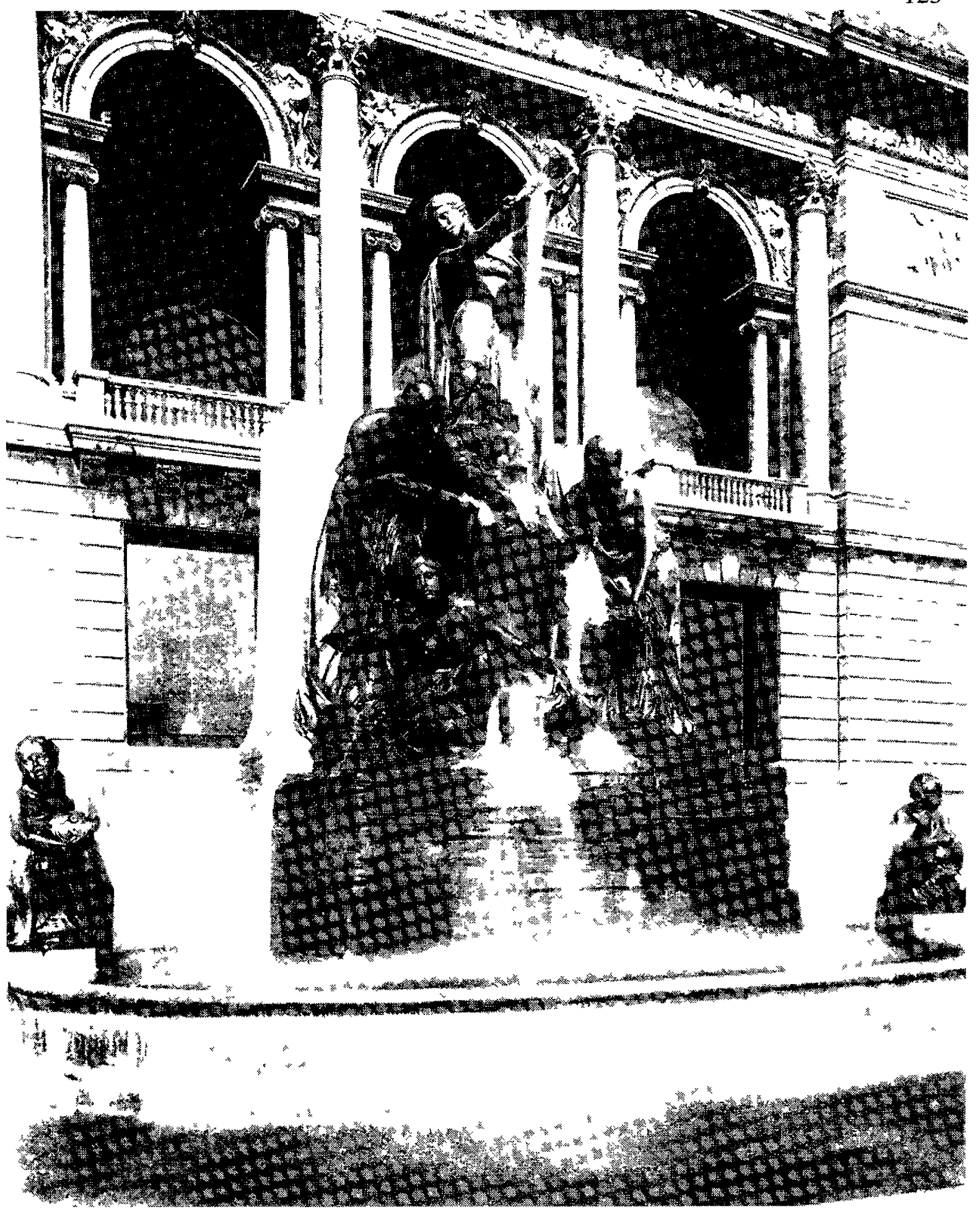

Fig. 5: Lorado Taft, Fountain of the Great Lakes (1913), pictured here in its original location outside the Art Institute of Chicago. Photo Credit: Timothy Garvey, Public Sculptor, Lorado Taft and the Beautification of Chicago (Urbana: University of Illinois Press, 1988). 


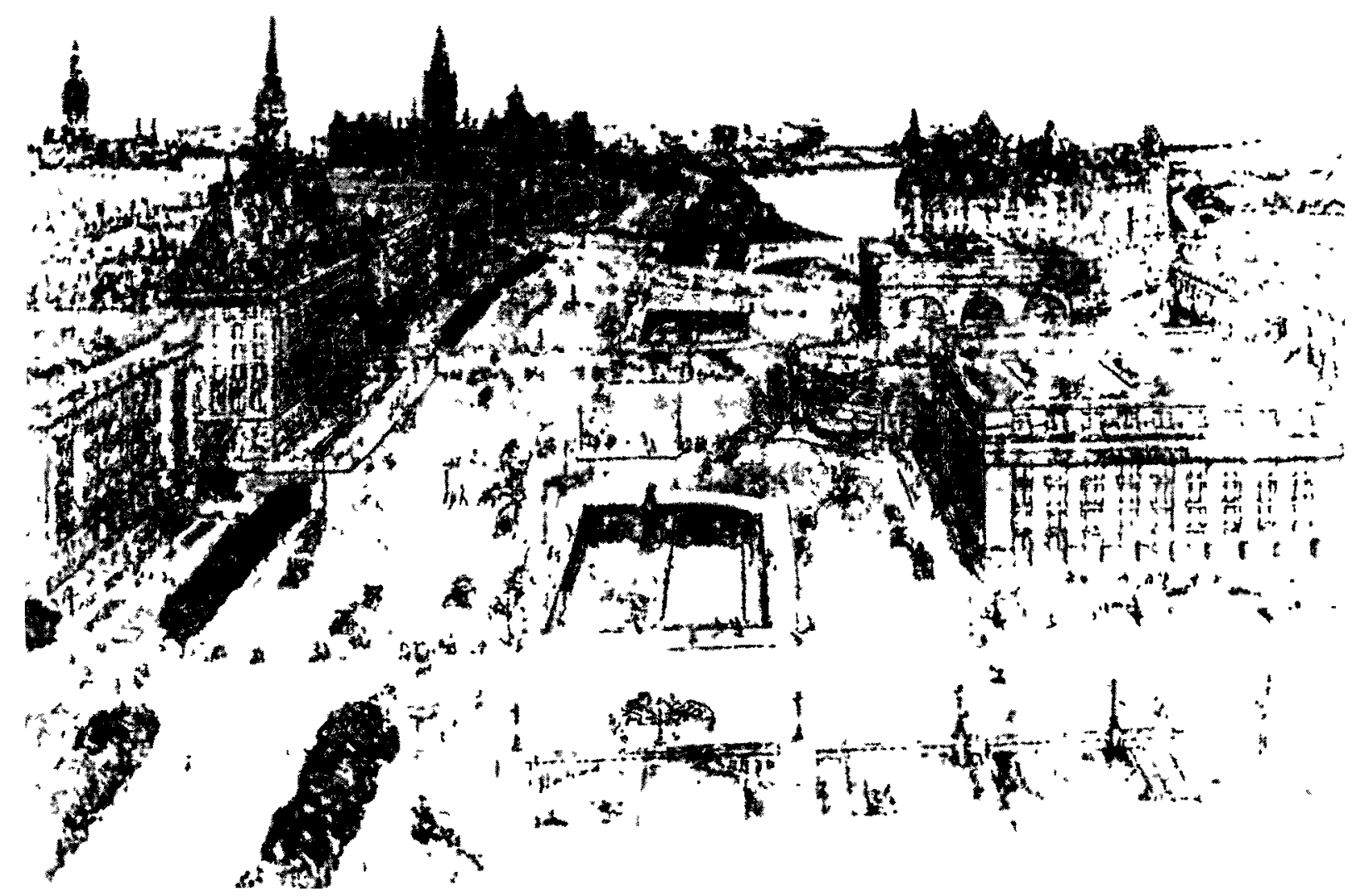

Fig. 6: Edward Bennett, City Beautiful design for Ottawa's civic centre including the existing Parliament Buildings at the top left (1915). 
The culy as an imgamian

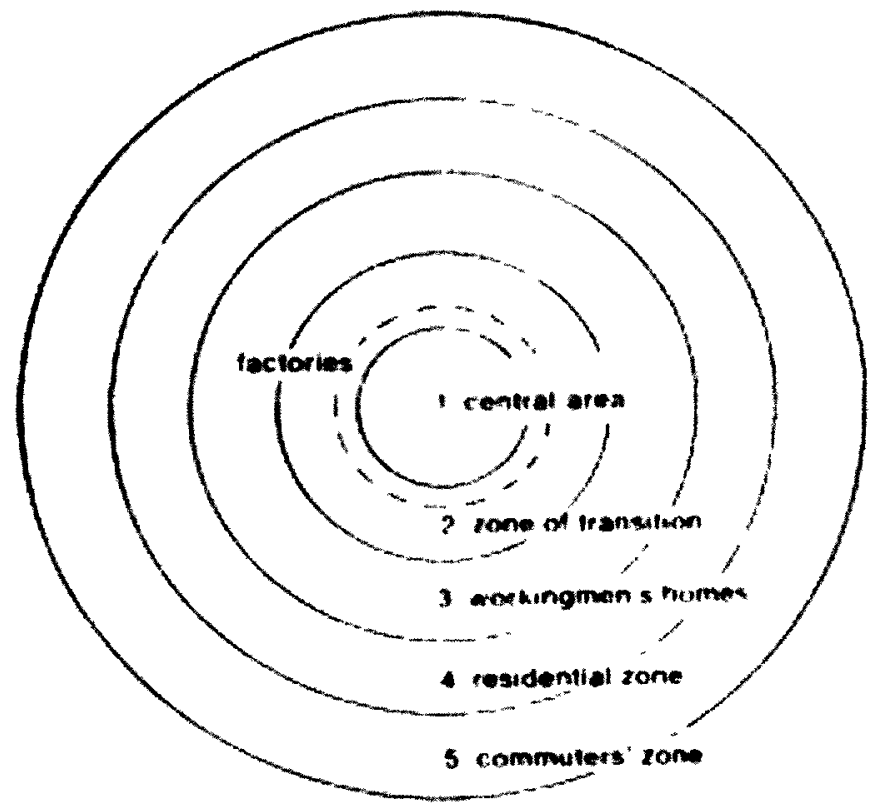

Ihagram I

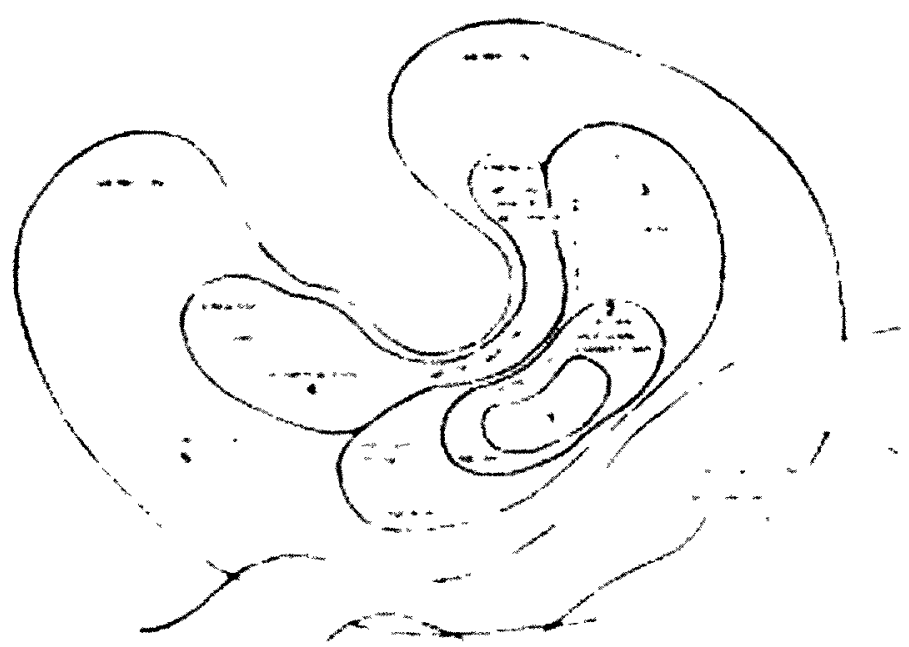

(Makram :

Fig. 7: C.A. Dawson, diagrams illustrating the theory of the city as an organism (c.1926). 


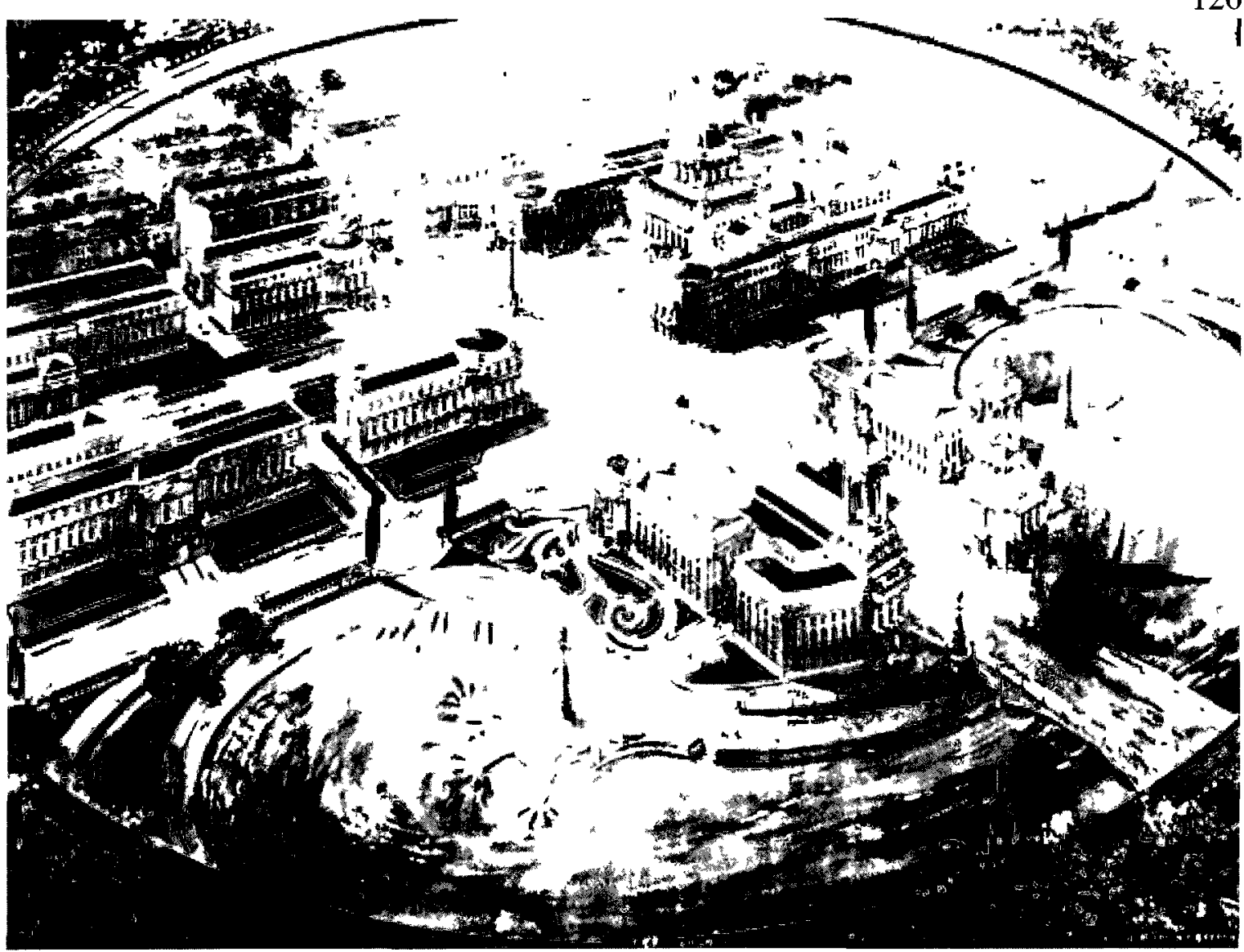

Fig. 8: Thomas Mawson, plan for the civic centre of Calgary (1914) 


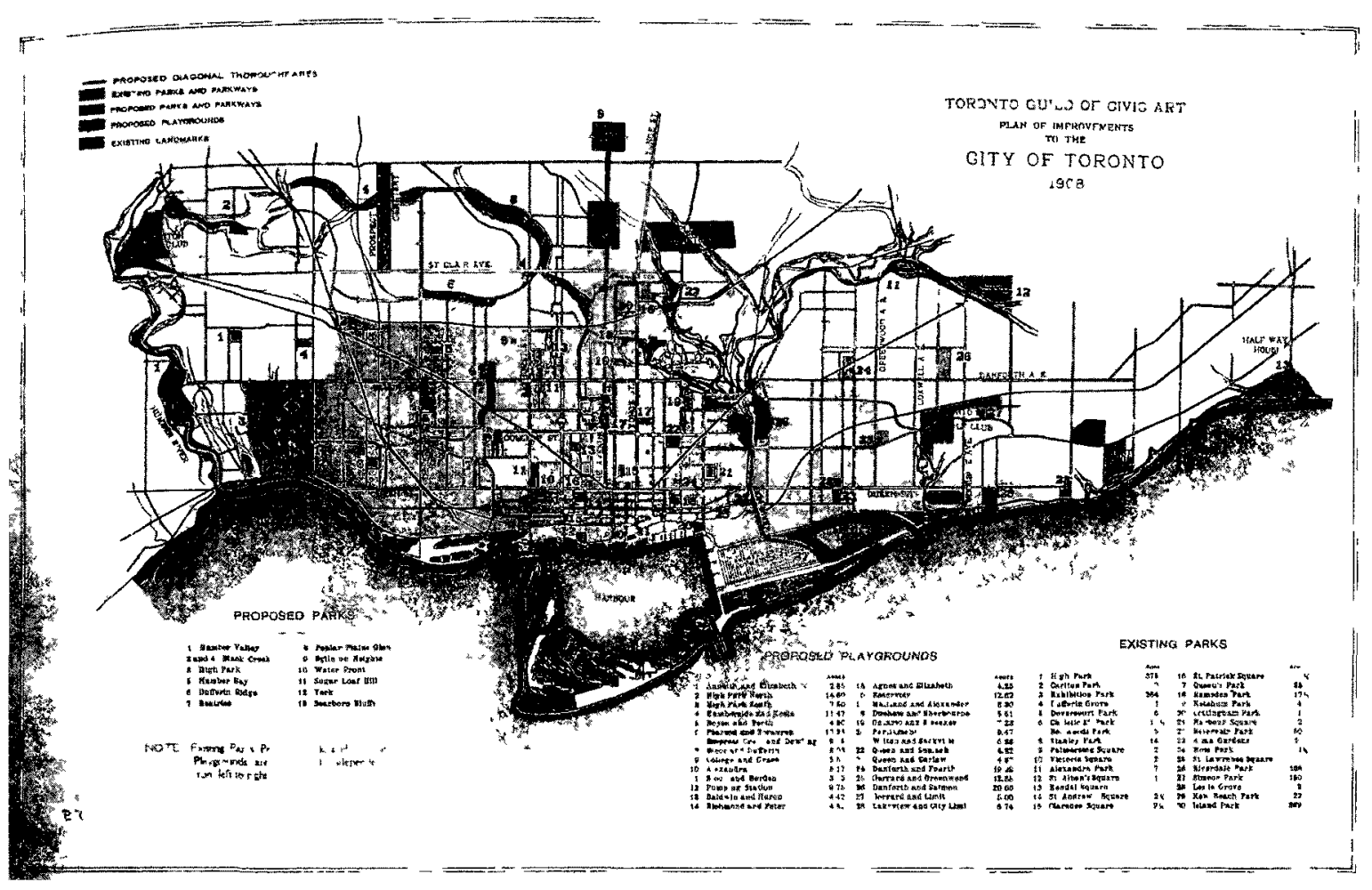

Fig. 9: The Toronto Guild of Civic Art, plan for Toronto. Includes provisions for park spaces and diagonal boulevards (1909). 


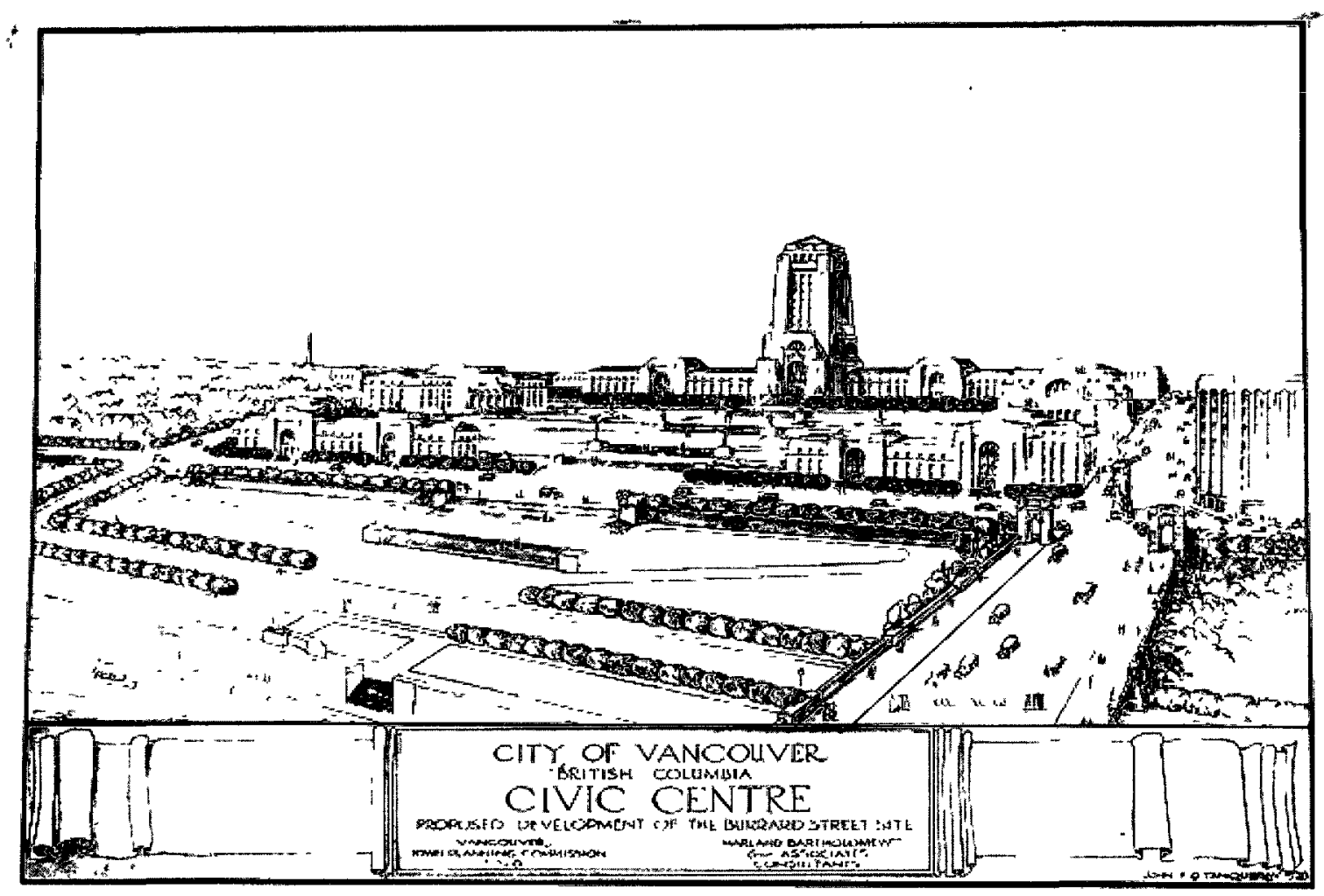

Fig. 10: Vancouver Town Planning Commission, design for a new civic centre (1930). 


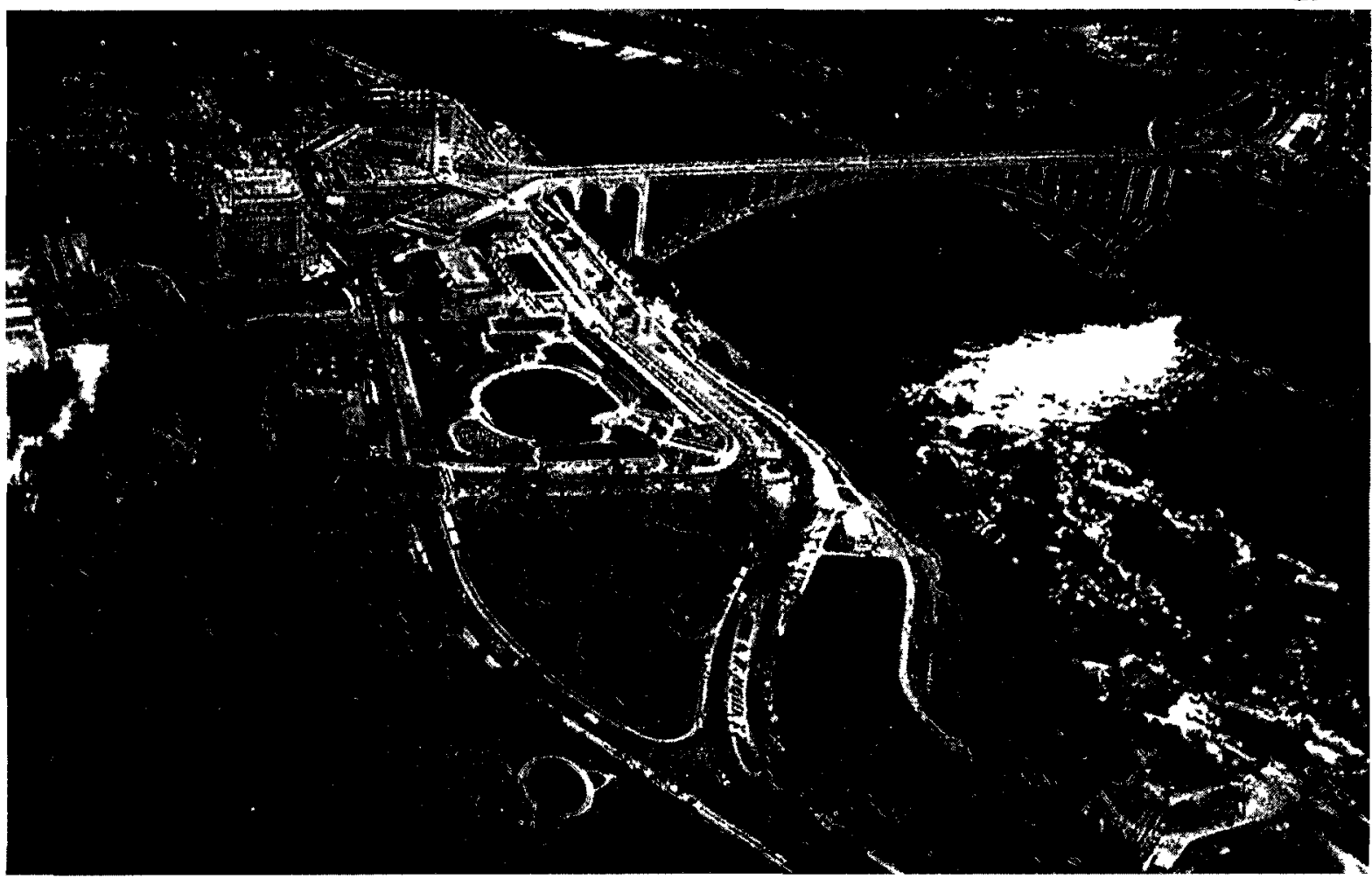

Fig. 11: Aerial view of beautification and improvements at Niagara Falls, including the Oakes Garden Theatre at centre and the Rainbow Bridge and Gardens in the upper middle (1935-1941). Photo Credit: Mary J. Anderson, Tragedy and Triumph: Ruby and Thomas Baker McQuesten (Dundas: Tierceron Press, 2011). 


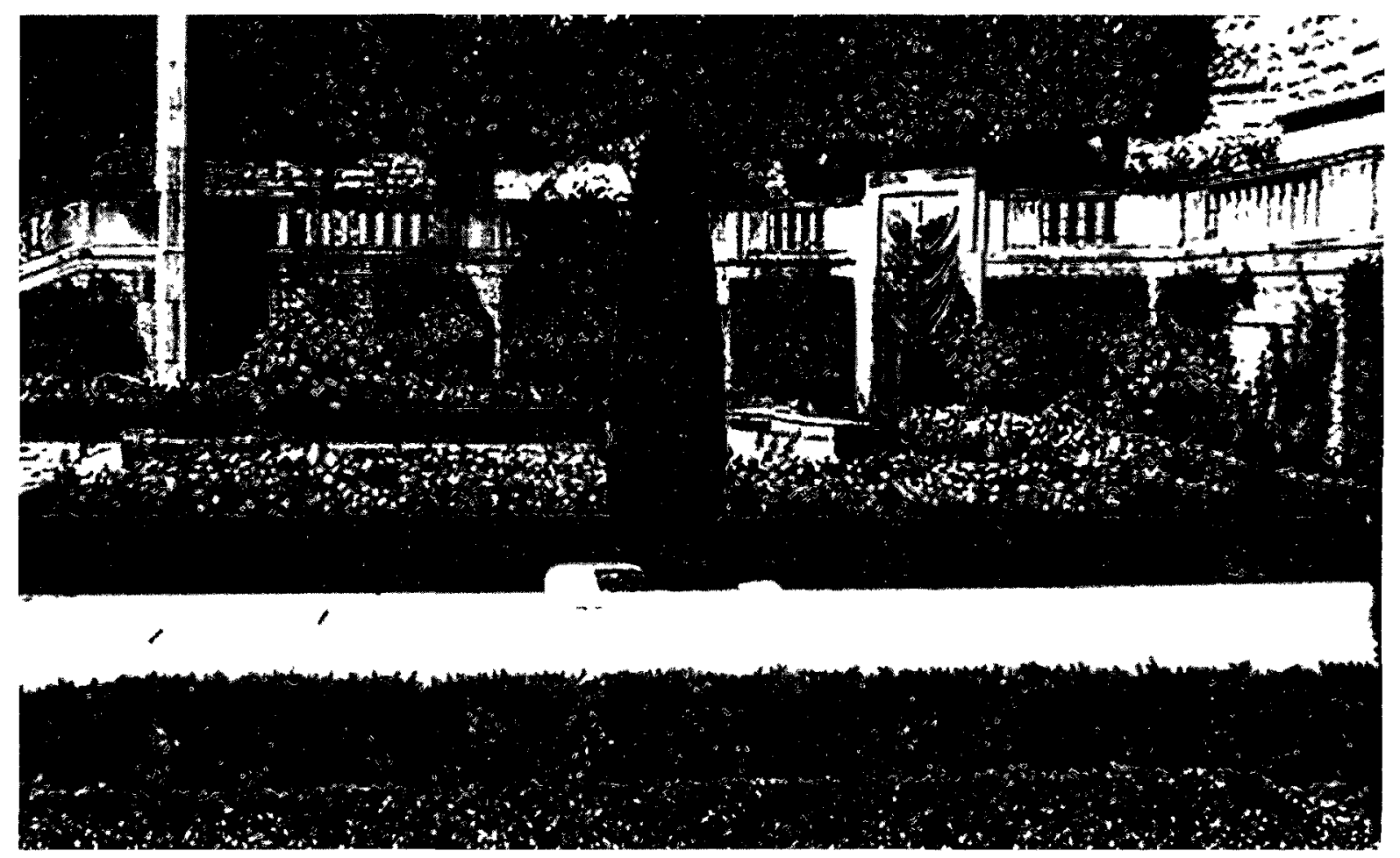

Fig. 12: Detail of the Rainbow Bridge Gardens at Niagara Falls including Elizabeth Wyn Wood's relief sculpture, Wild Geese (c. 1940), in situ at the garden. Photo Credit: Mary J. Anderson, Tragedy and Triumph: Ruby and Thomas Baker McQuesten (Dundas: Tierceron Press, 2011). 

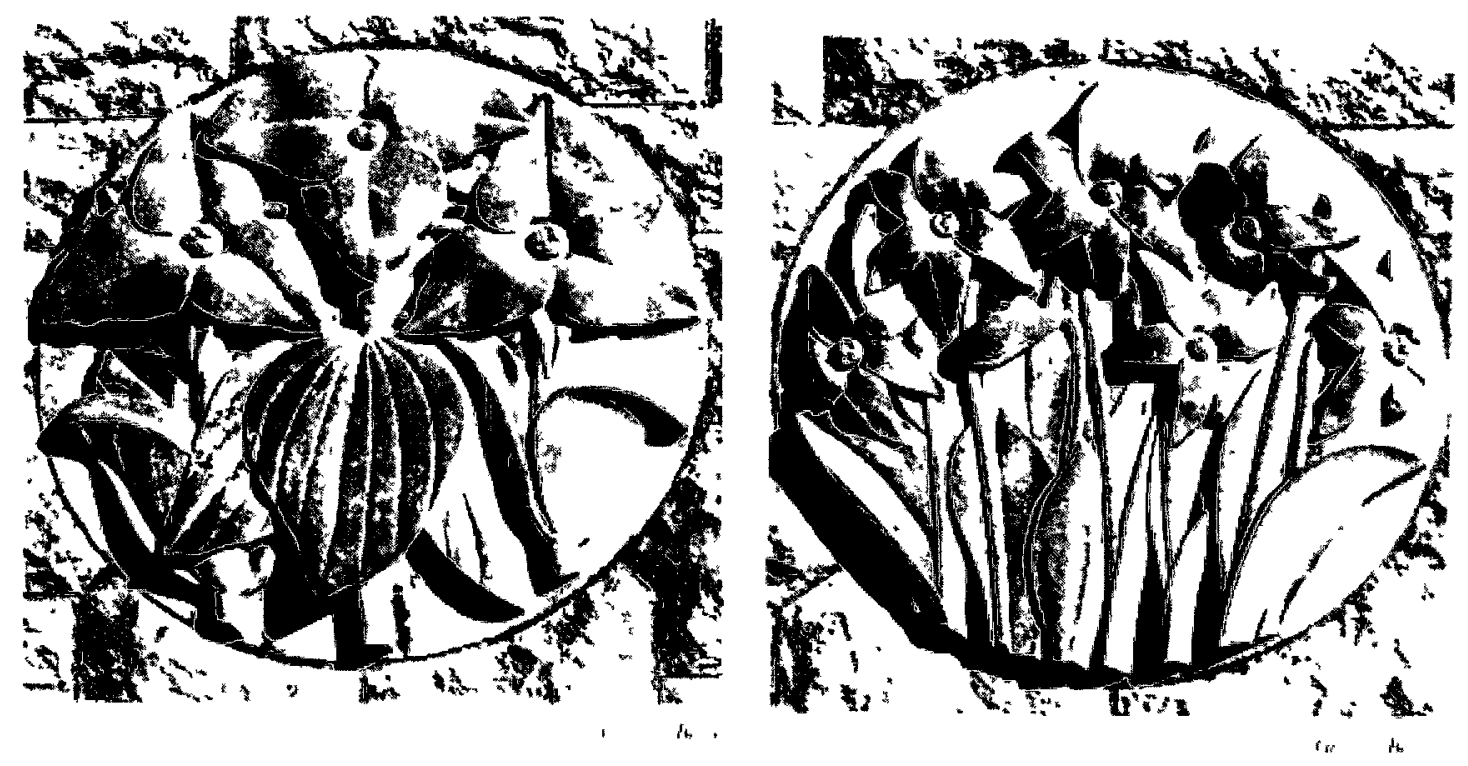

Fig. 13: Frances Loring and Florence Wyle, stylized panels of Canadian flora from the Oakes Garden Theatre at Niagara Falls (c. 1940). Photo Credit: George Bailey. 


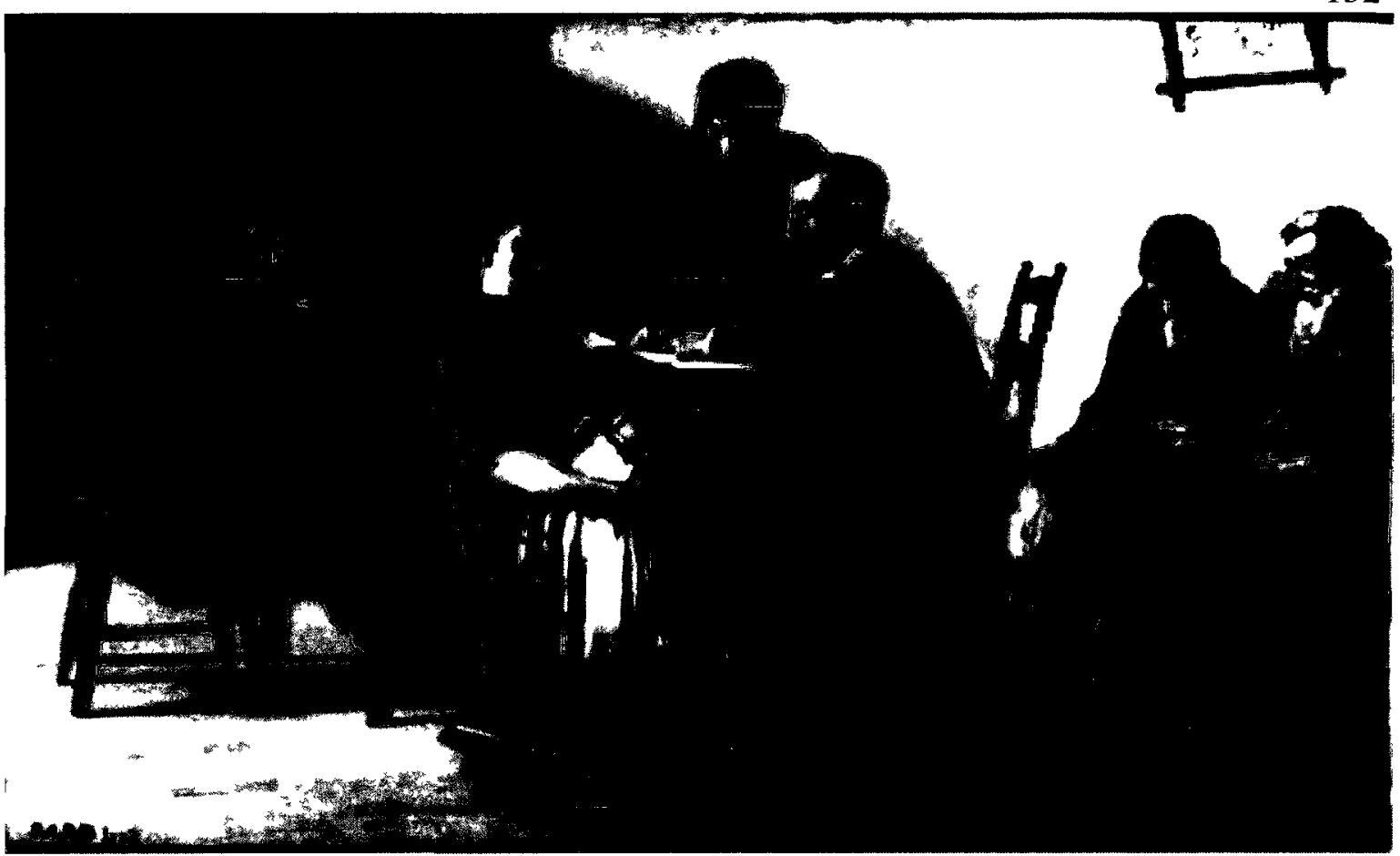

Fig. 14: George A. Reid, Mortgaging the Homestead (1890). $131.1 \times 213.3 \mathrm{~cm}$. Photo Credit: National Gallery of Canada. 


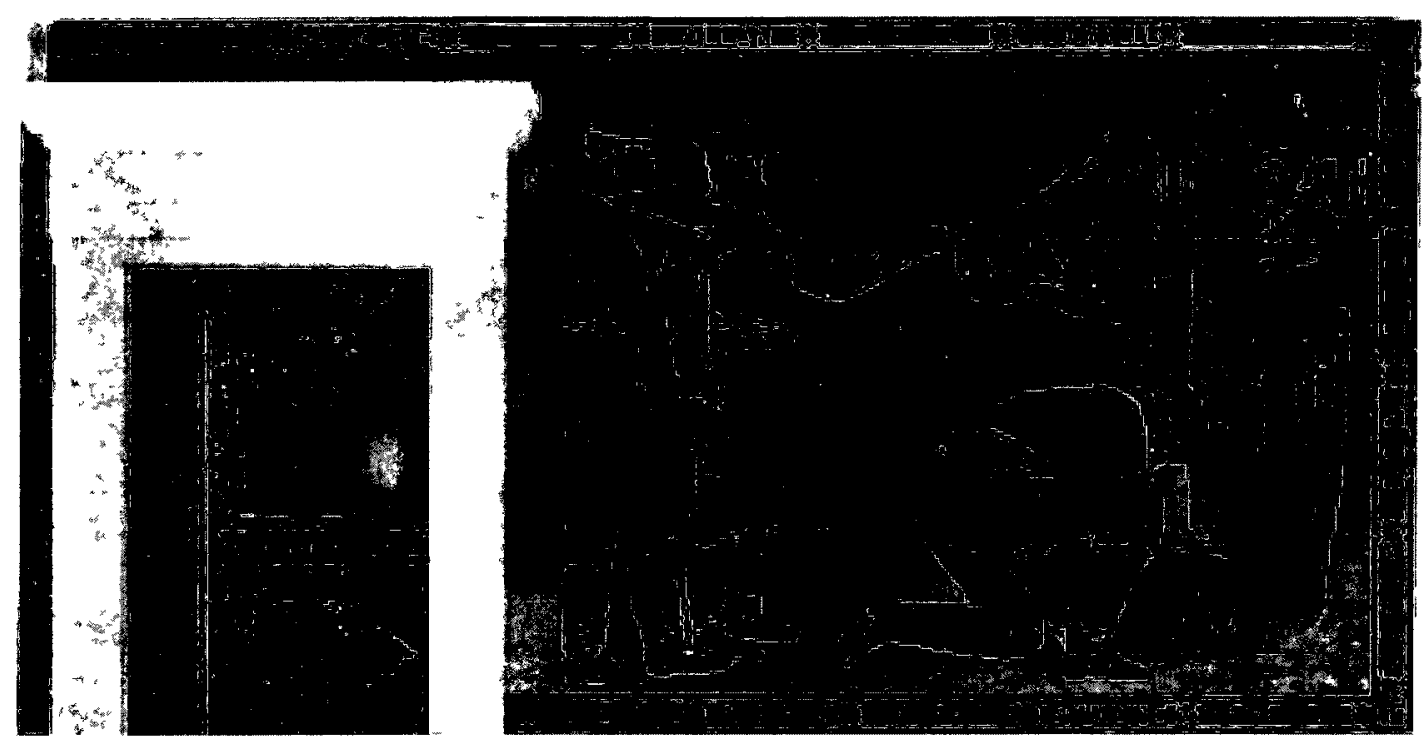

Fig. 15: George A. Reid, The Arrival of the Pioneers in the Toronto Municipal Buildings (1897-1899). $213 \times 427 \mathrm{~cm}$. 


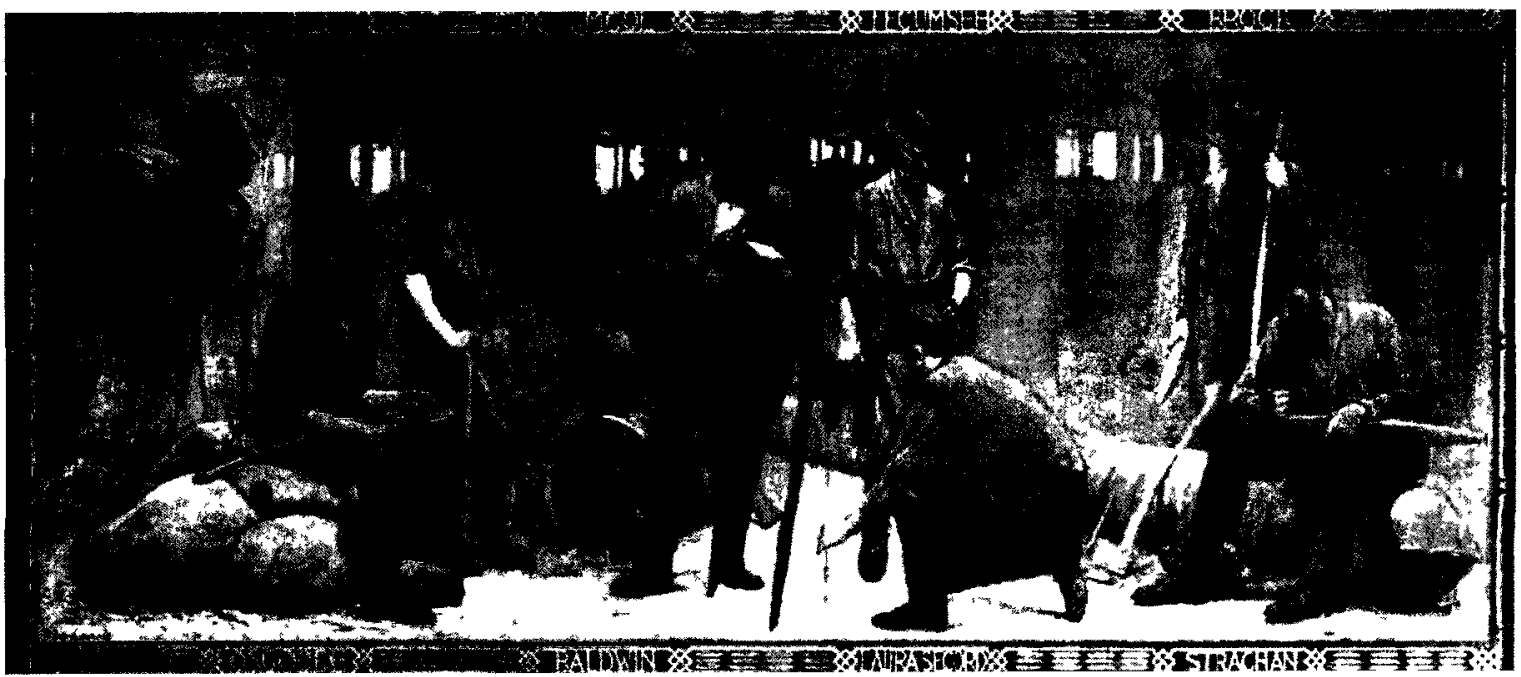

Fig. 16: George A. Reid, Staking a Pioneer Farm in the Toronto Municipal Buildings (1897-1899). $213 \times 518 \mathrm{~cm}$. 

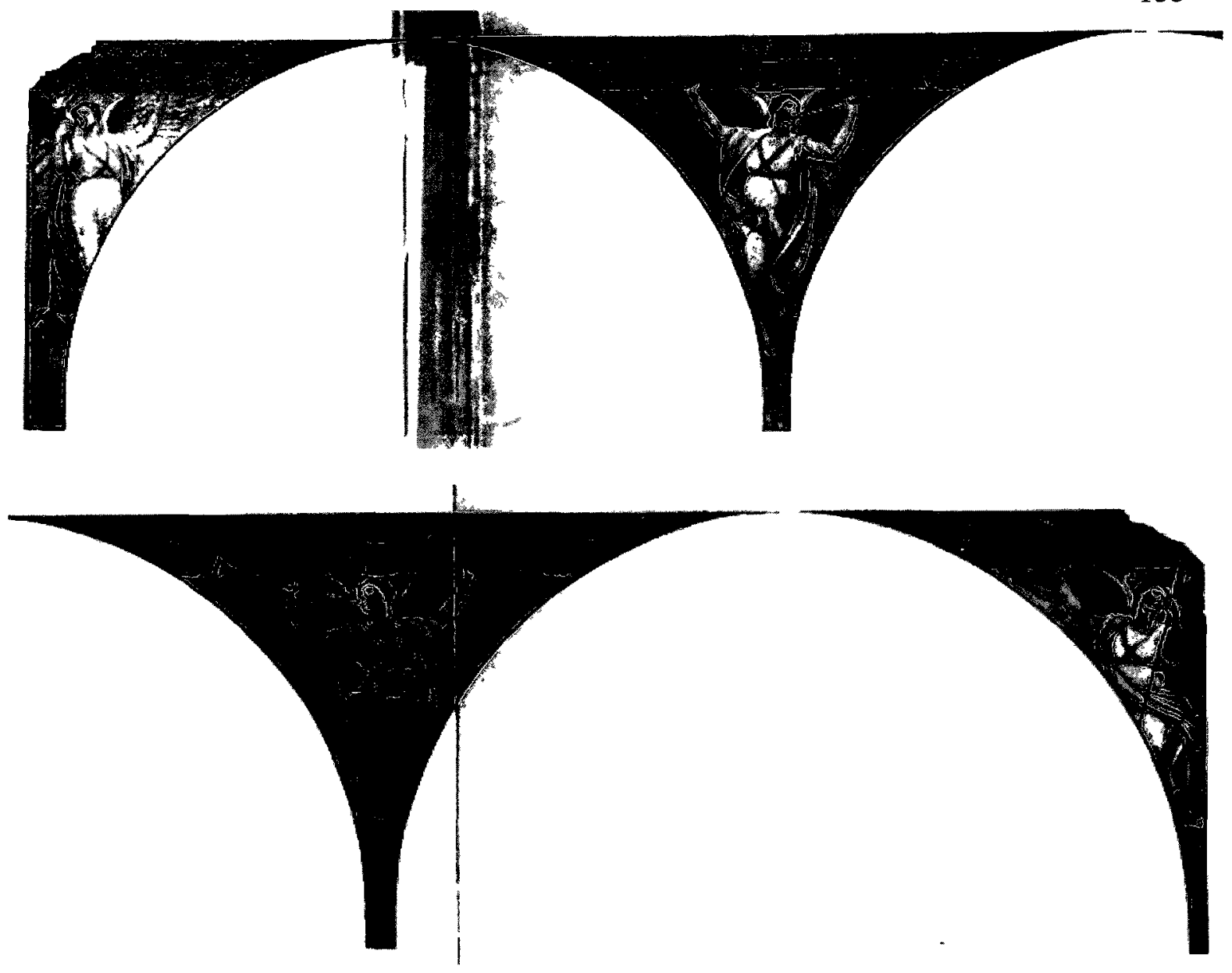

Fig. 17: George A. Reid, Discovery, Fame, Fortune, and Adventure, Spandrel figures in the Toronto Municipal Buildings (1897-1899). 


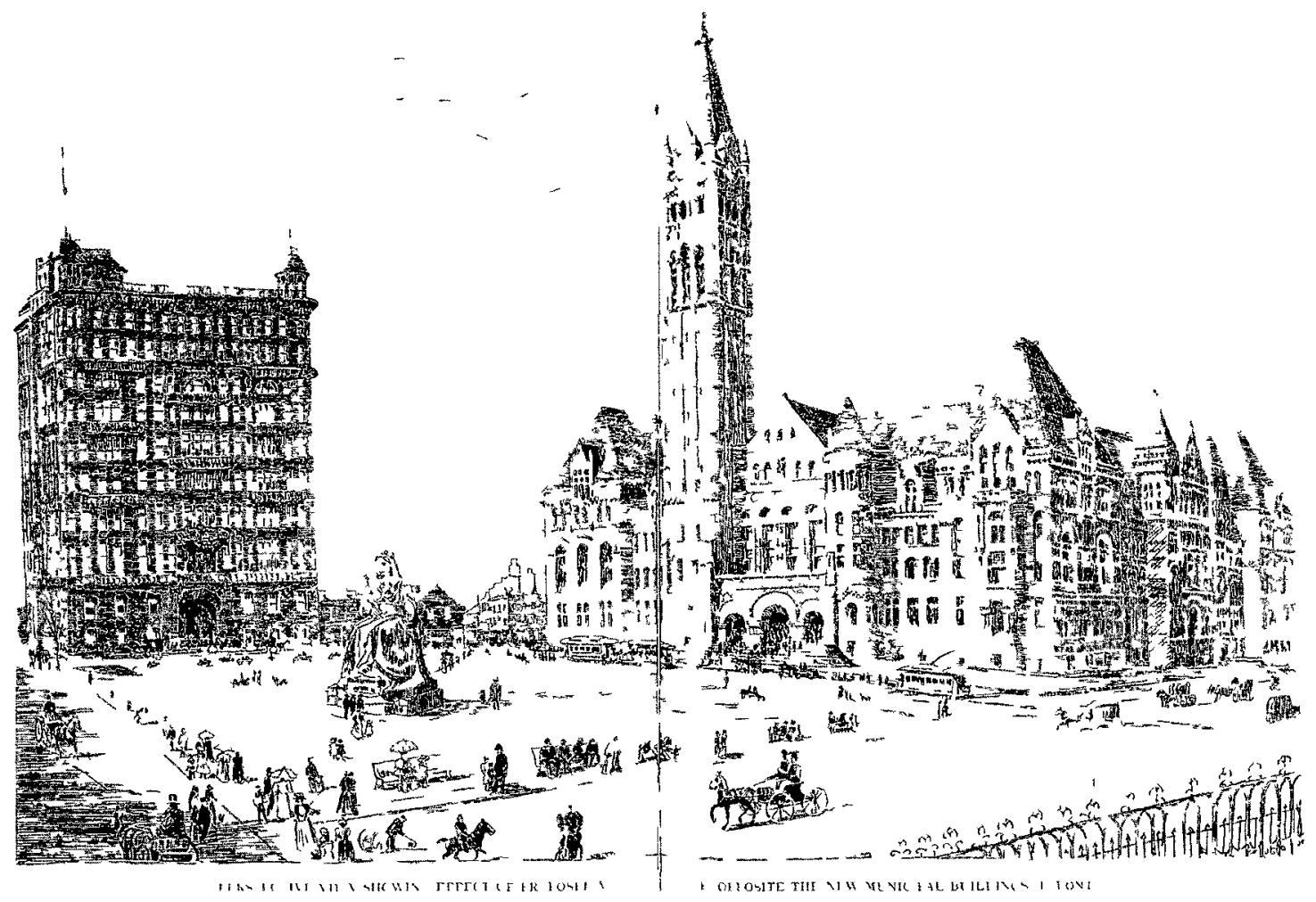

Fig. 18: Design for Victoria Square, Toronto (1897) Photo Credit Mark Osbaldeston, Unbuilt Toronto: A History of the City That Might Have Been (Toronto: Dundurn Press, 2008). 


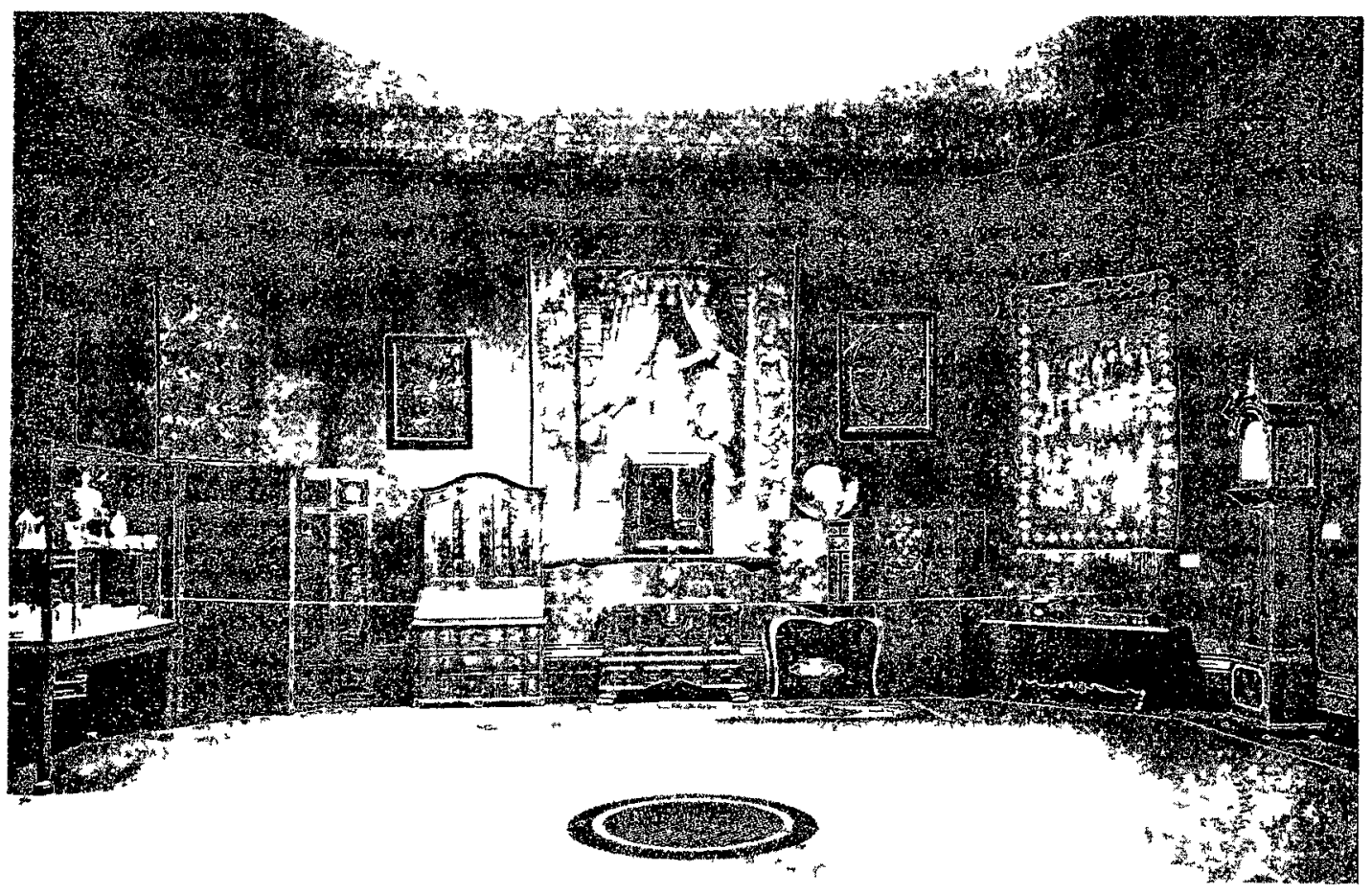

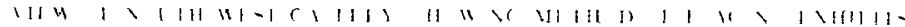

Fig. 19: Installation photograph from the First Biennial Exhibition of Architecture and the Allied Arts at the Art Gallery of Toronto (1927) 


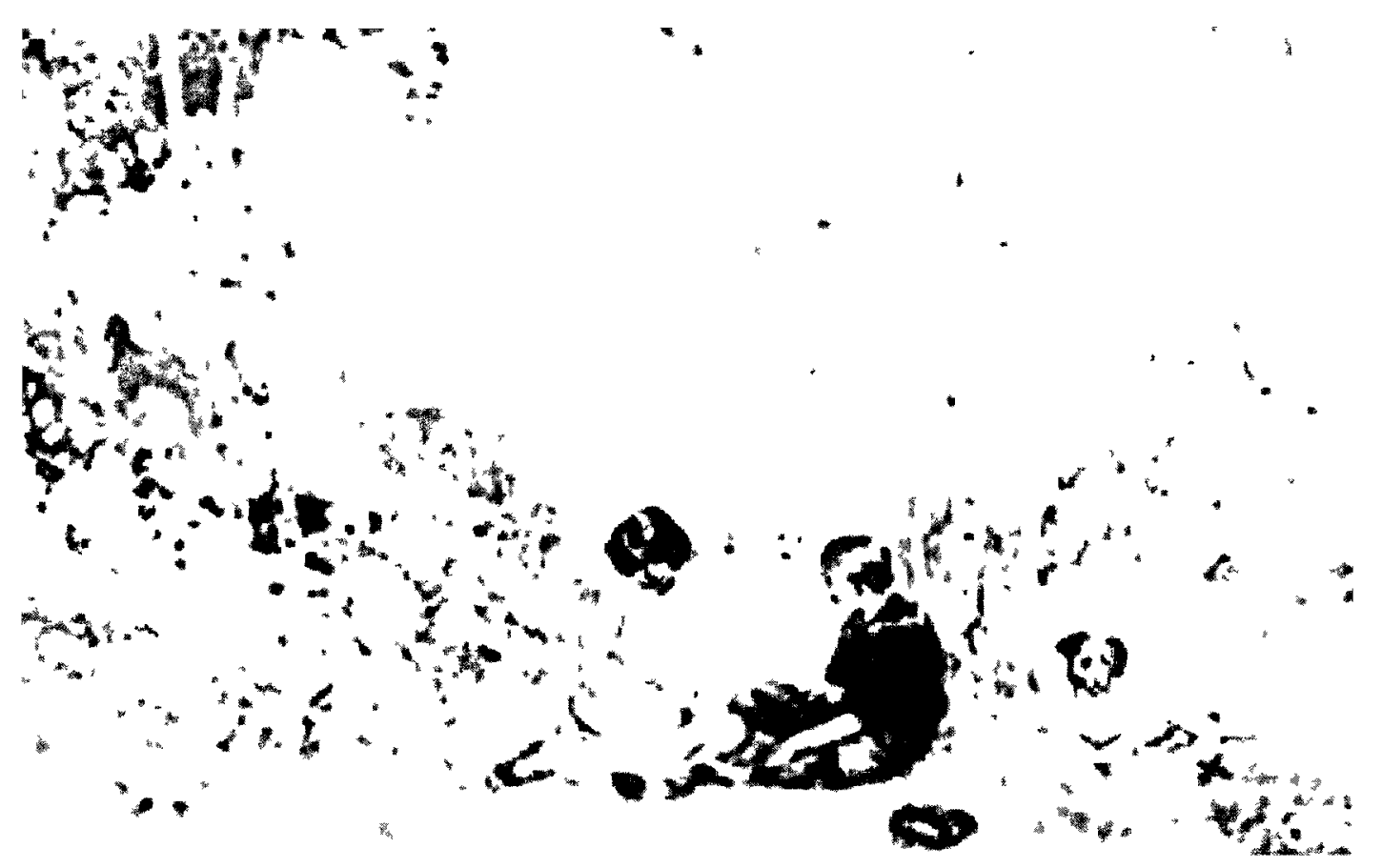

Fig. 20: Frederick Challener, The Enchanted Wood mural series from the Parkwood estate, Oshawa (c.1925). Photo Credit: Parkwood National Historic Site. 


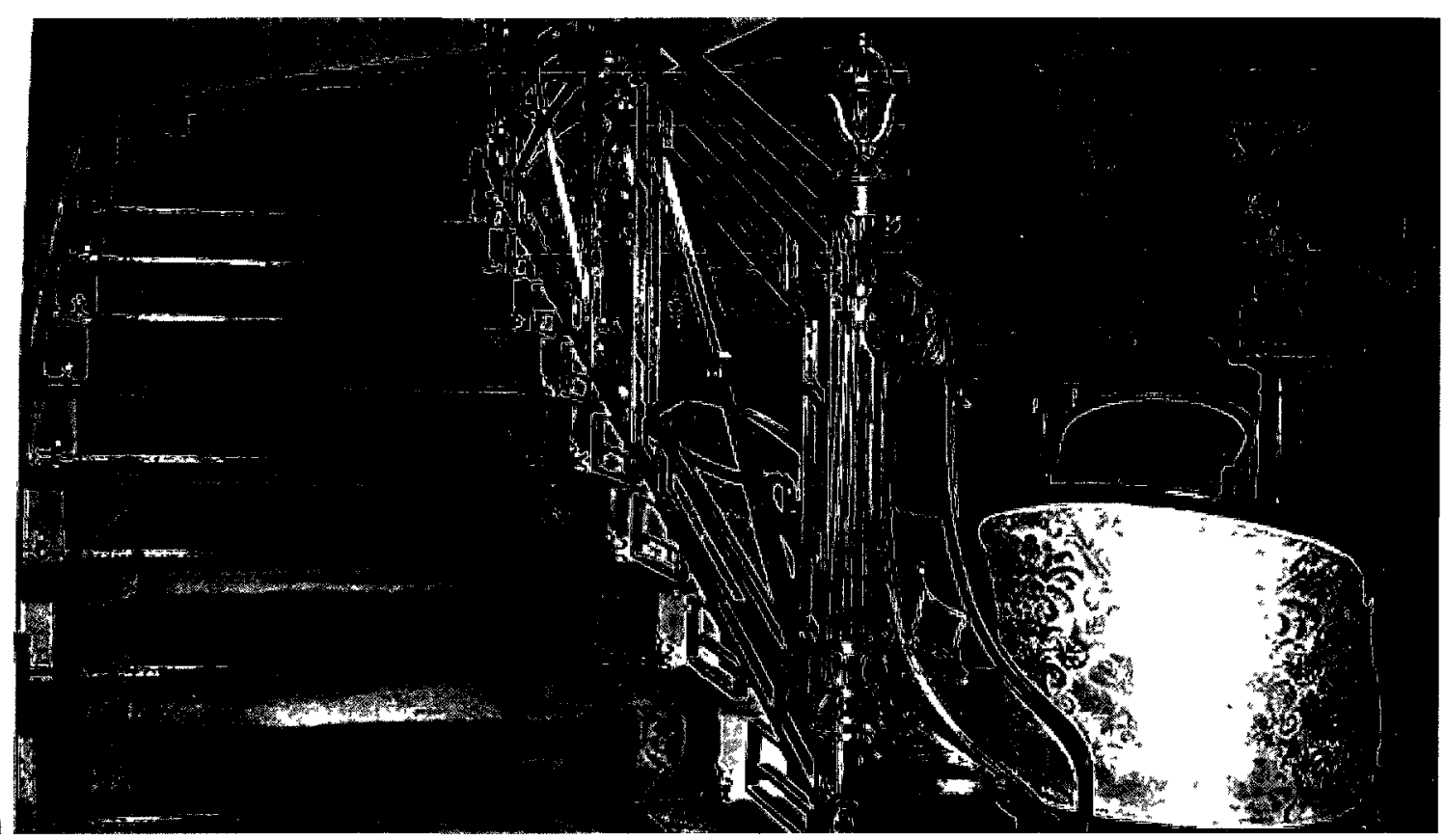

Fig. 21: Frederick Haines, mural series in the entrance hallway at Parkwood depicting formal gardens (c. 1930). Photo Credit: Parkwood National Historic Site. 


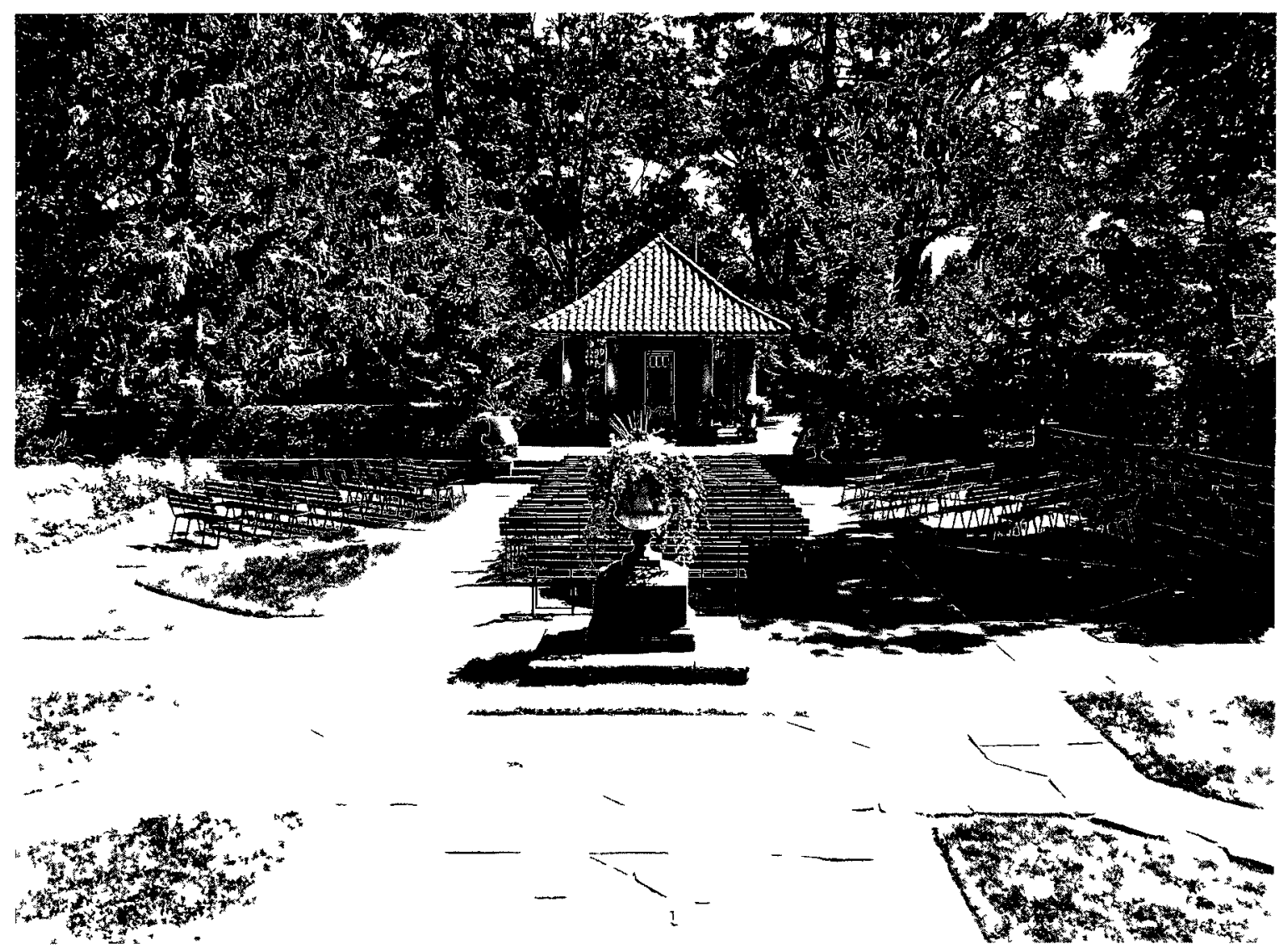

Fig. 22: Lorrie and Howard Dunıngton-Grubb, Sunken Garden at the Parkwood Estate, Oshawa (1927) Photo Credit Julıe Nash 


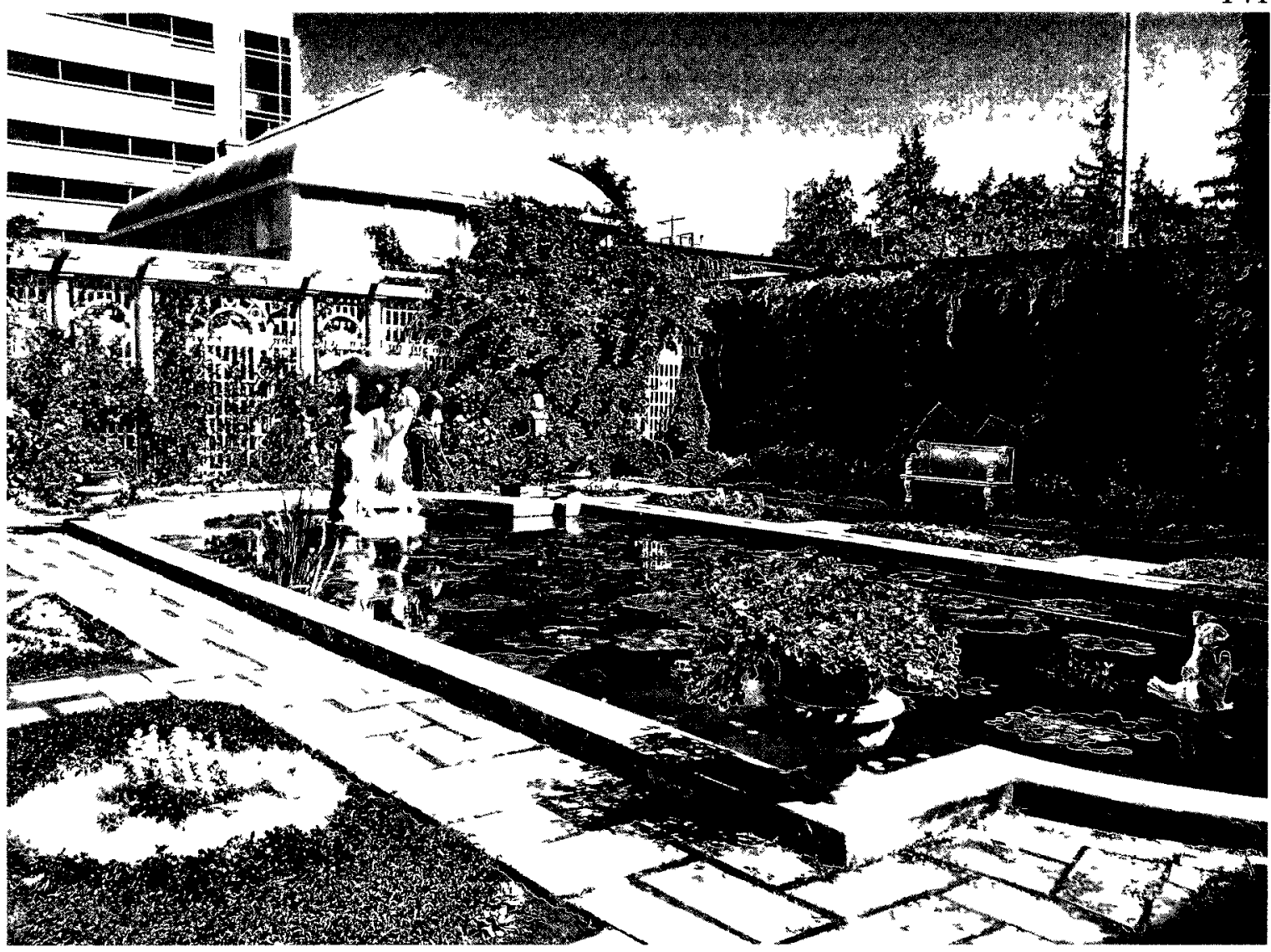

Fig. 23: Lorrie and Howard Dunington-Grubb, Italian Garden at the Parkwood Estate, Oshawa (1927). Photo Credit: Julie Nash. 


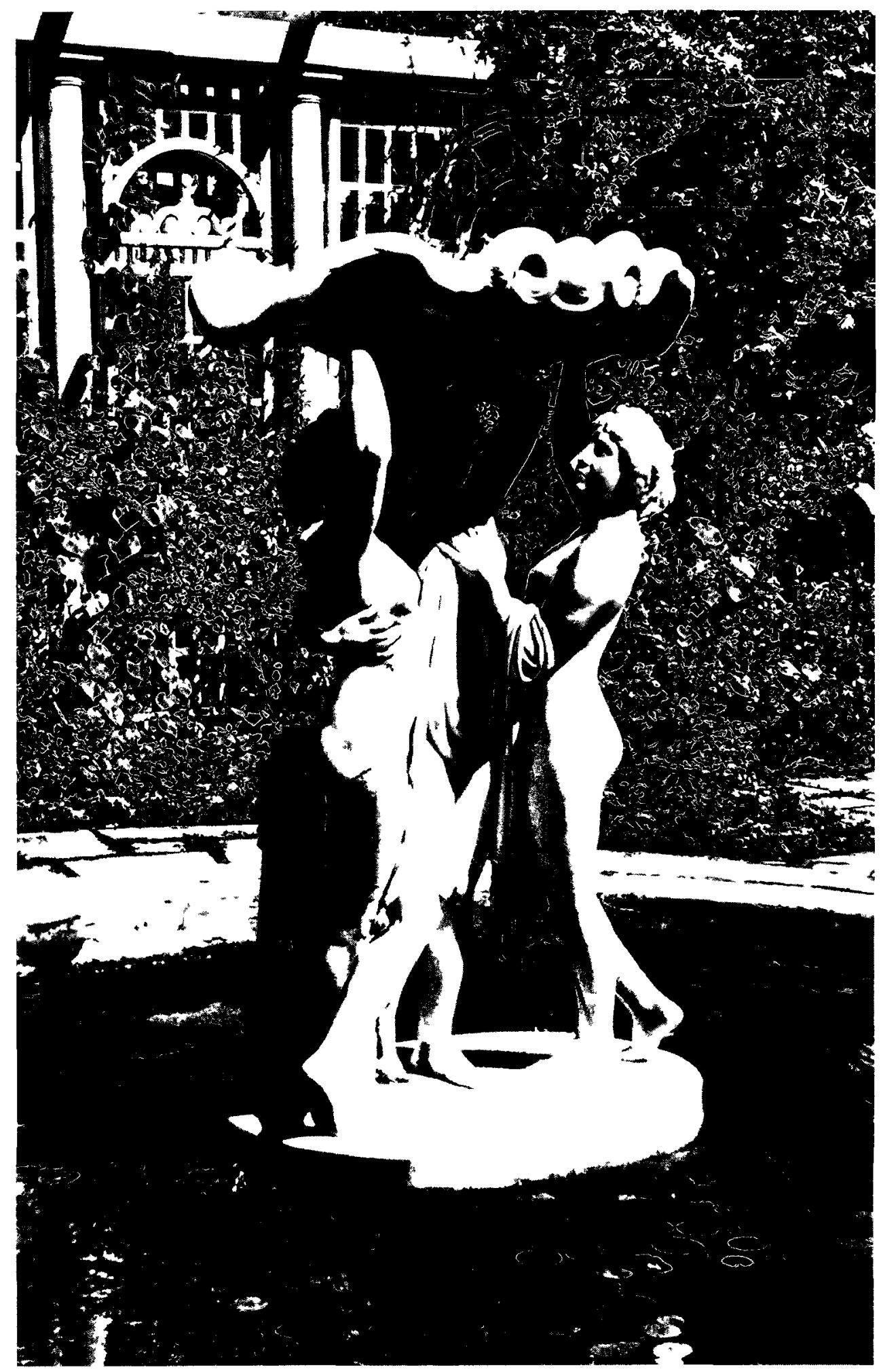

Fig. 24: Detail of sculptural group in the Dunington-Grubbs' Italian Garden at the Parkwood Estate, Oshawa (c. 1927). Photo Credit: Julie Nash. 


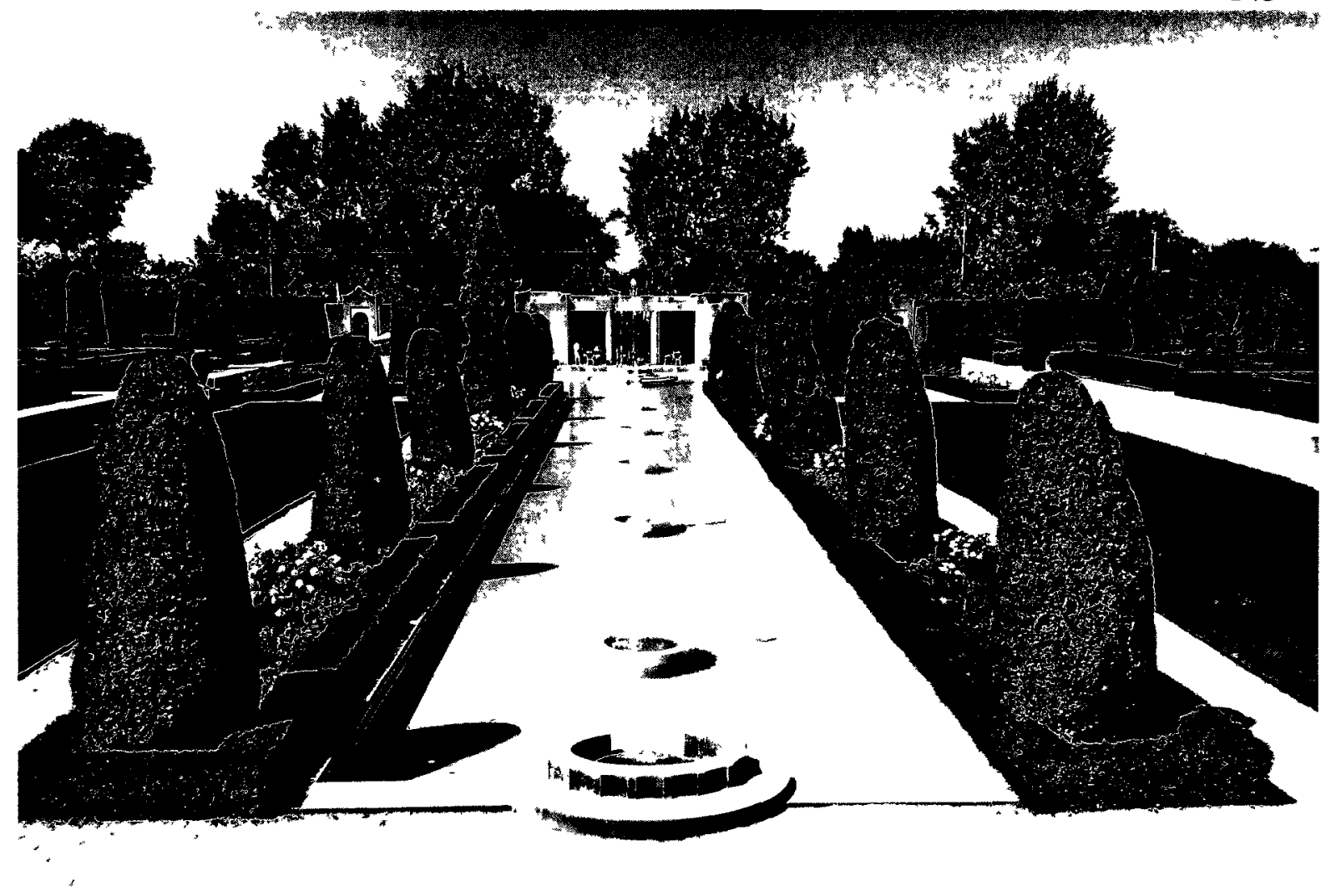

Fig. 25: John Lyle, Formal Fountain and Garden at the Parkwood Estate, Oshawa (c.1935-1936). Photo Credit: Julie Nash. 


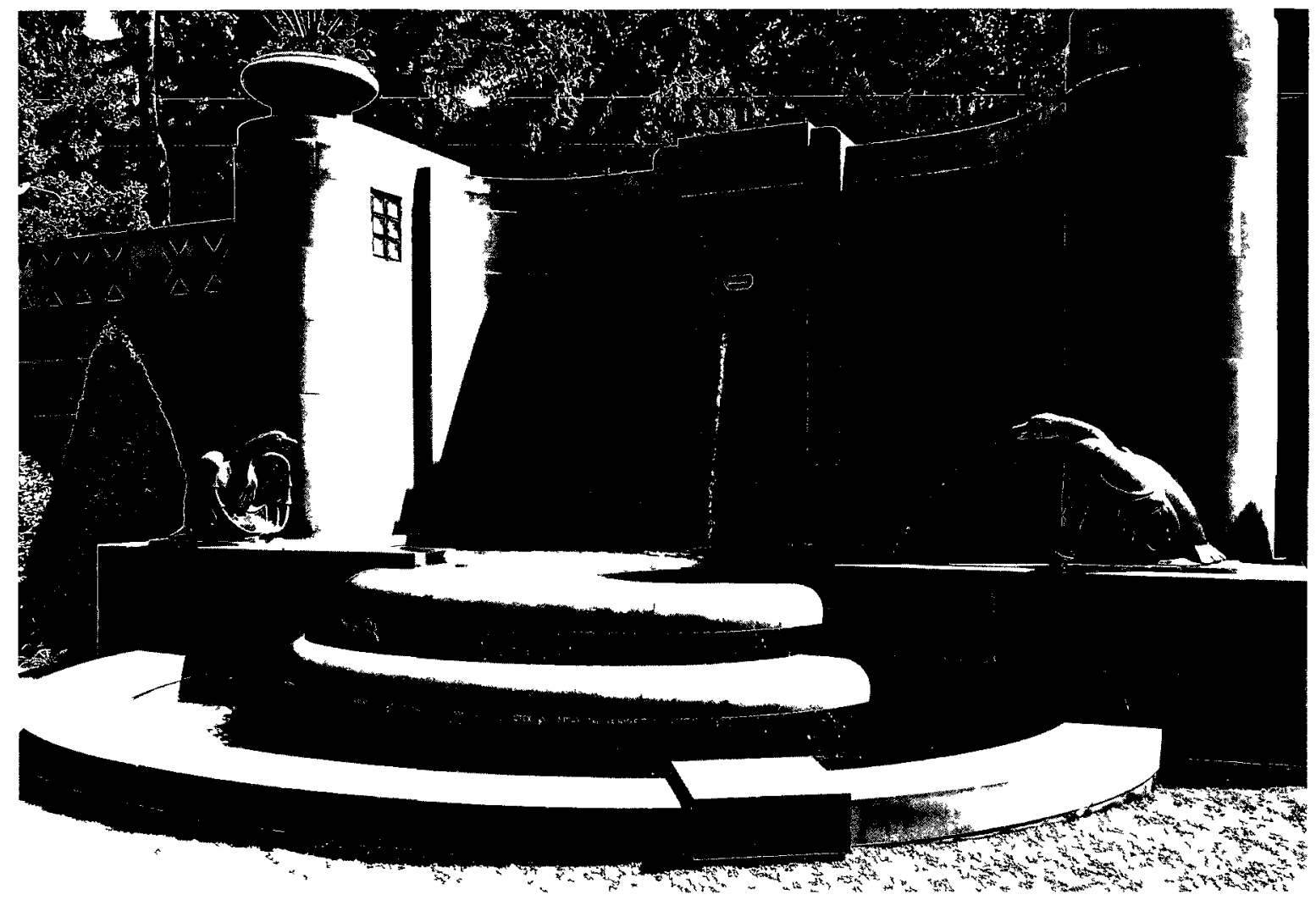

Fig. 26: John Lyle, balcony and fountains of the Formal Fountain at the Parkwood Estate, Oshawa (c 1935-1936) Photo Credit: Julie Nash 


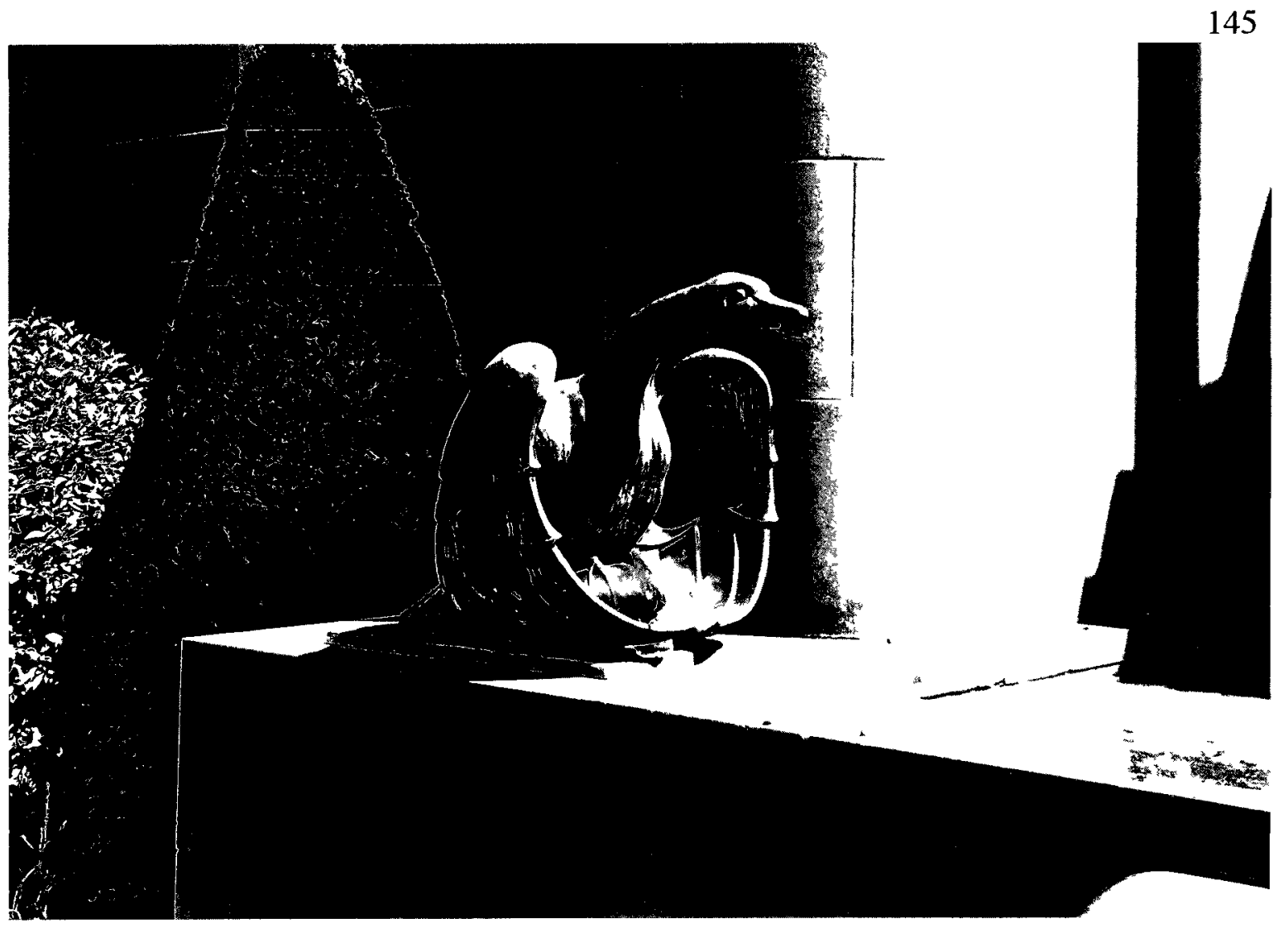

Fig. 27: Bronze Geese from the Formal Fountain at the Parkwood Estate, Oshawa (c.1935-1936). Photo Credit: Julie Nash. 


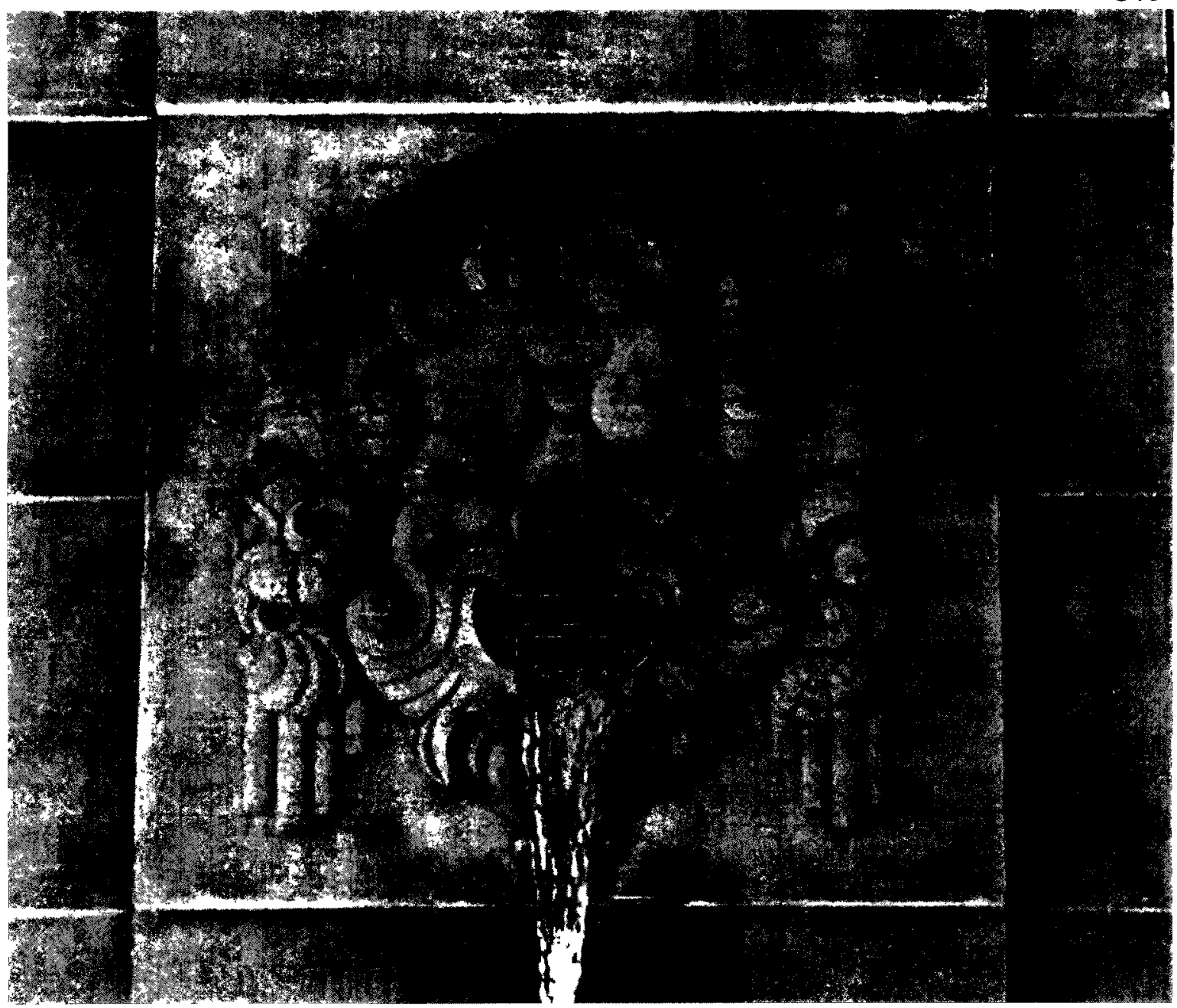

Fig. 28: Head of Neptune from the Formal Fountain at the Parkwood Estate, Oshawa (c. 1935-1936). Photo Credit: Julie Nash. 


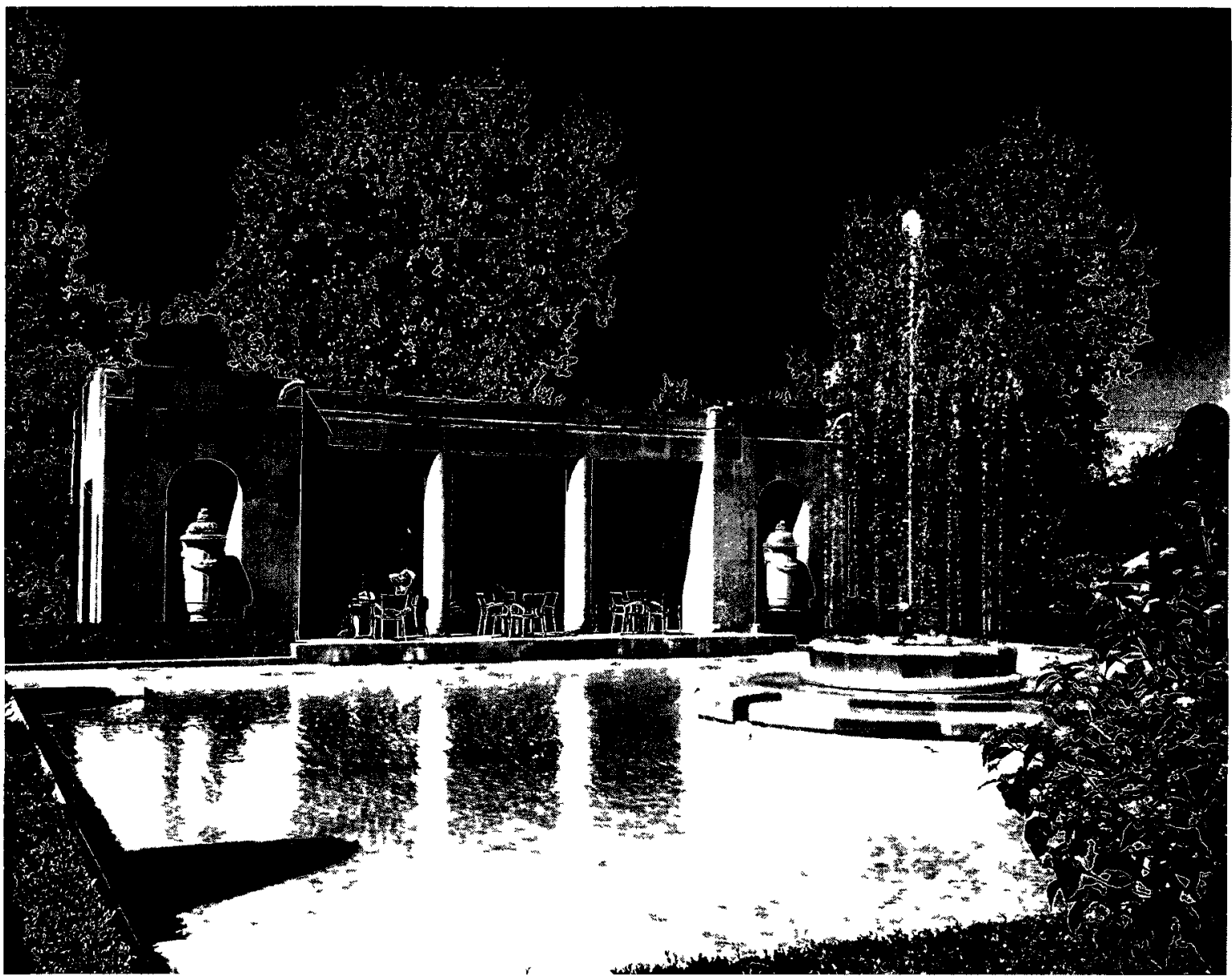

Fig. 29: John Lyle, Teahouse of the Formal Fountain at the Parkwood Estate, Oshawa (c 1935-1936). Photo Credit: Julie Nash. 


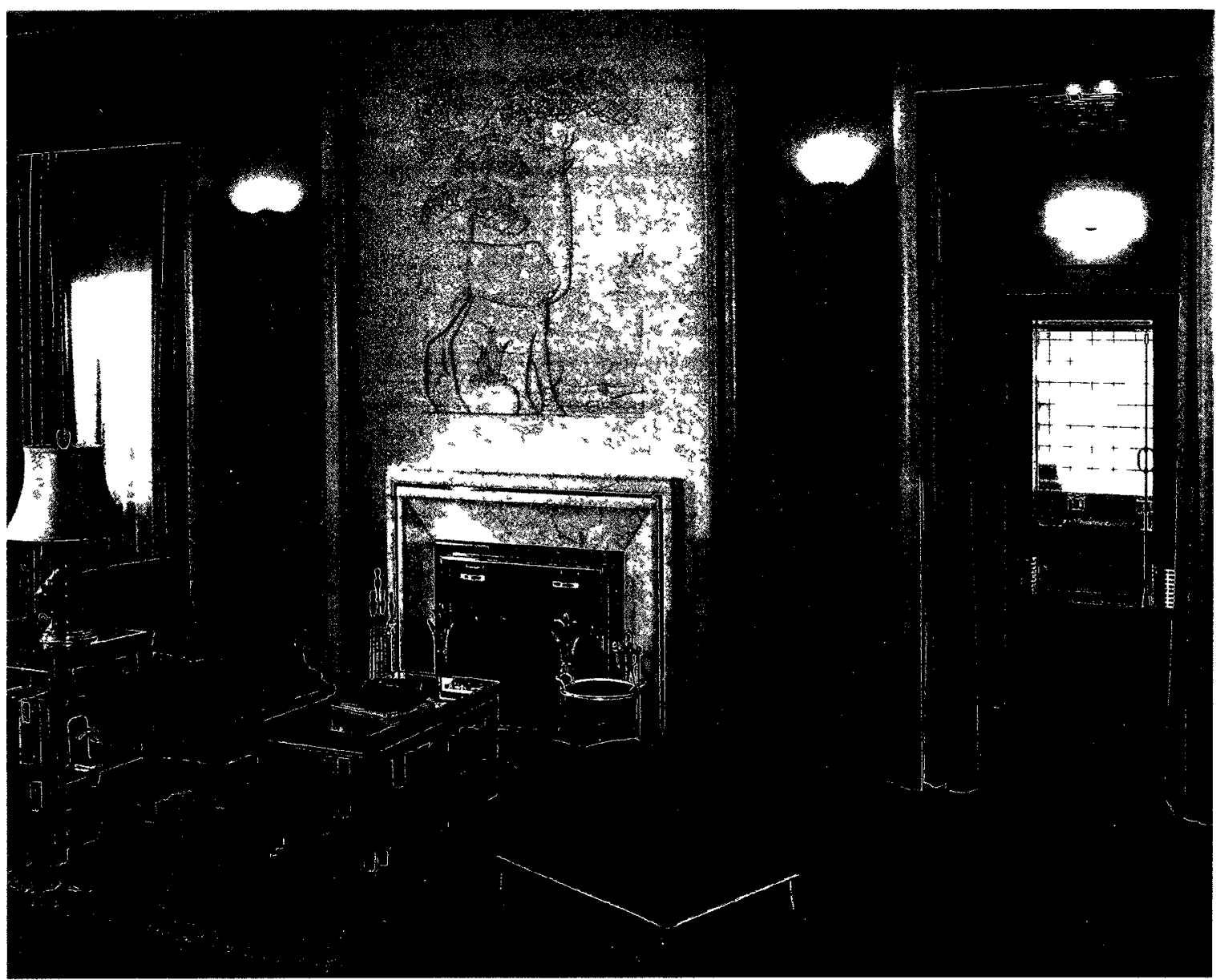

Fig. 30: John Lyle, design for Colonel R.S. McLaughlin's bedroom at the Parkwood Estate, featuring a Stag and Doe relief panel (c. 1935). Photo Credit: Glenn McArthur, $A$ Progressive Traditionalist: John M. Lyle, Architect (Toronto: Coach House Books, 2009). 


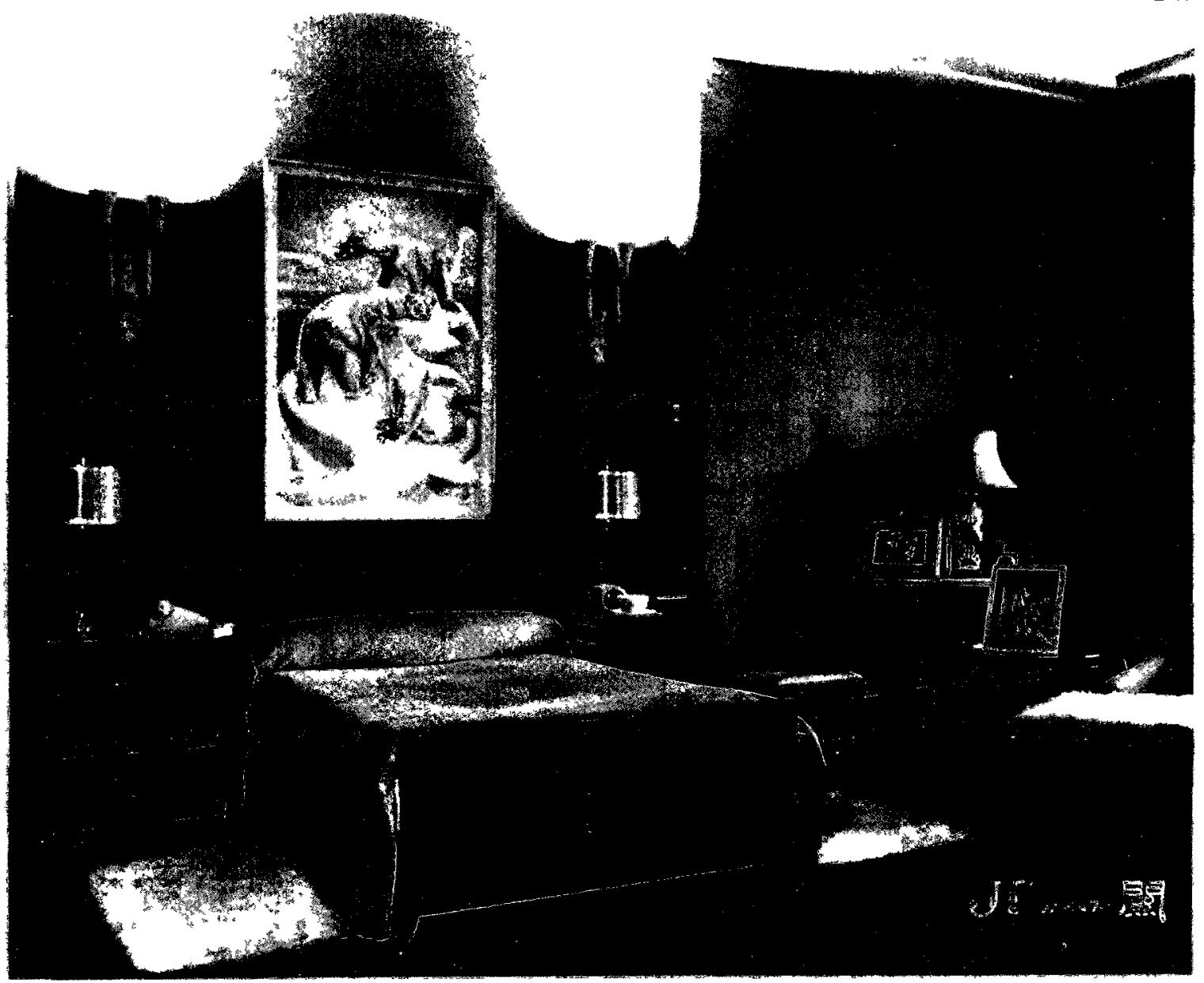

Fig. 31: John Lyle, design for Colonel R.S. McLaughlin's bedroom at the Parkwood Estate, including furniture pieces (c. 1935). Photo Credit: Stephanie Beatty and Susan Gale Hall, Parkwood (Erin: Boston Mills Press, 1999). 


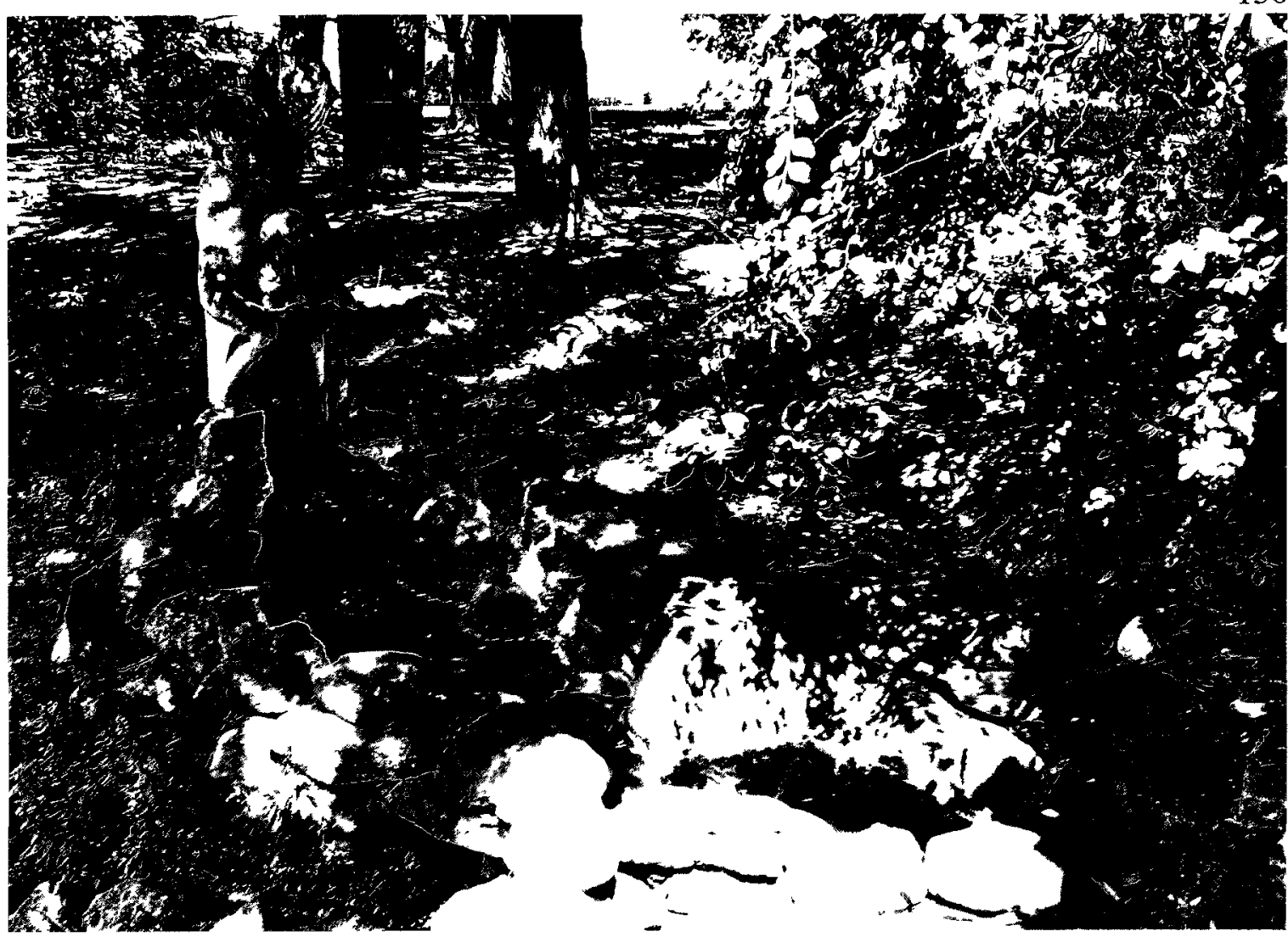

Fig. 32: Florence Wyle, Baby with Dolphin (c. 1923), in situ at the Parkwood Estate and Gardens, Oshawa. Photo Credit: Julie Nash. 


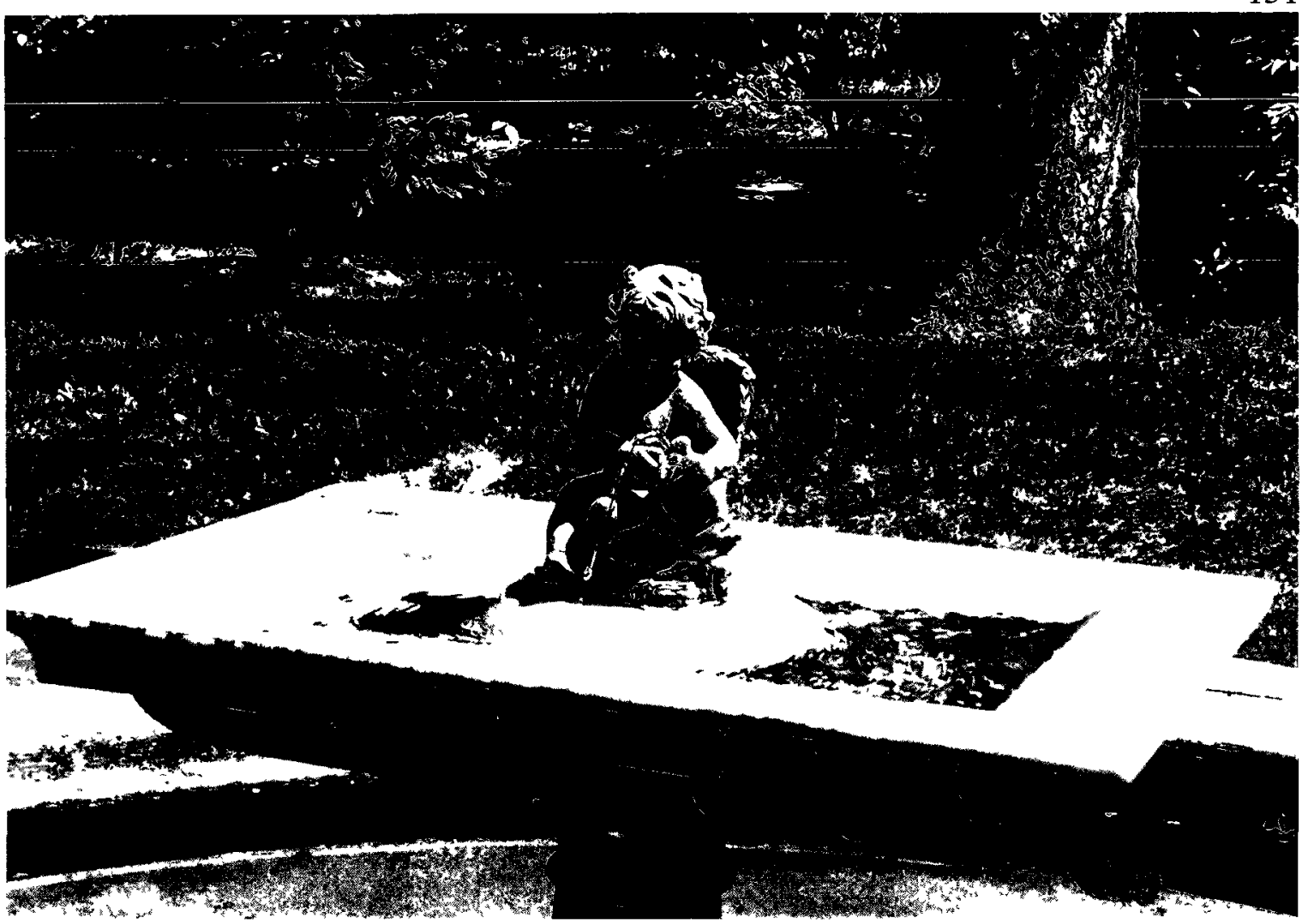

Fig. 33: Sculptural Fountain in the Dunington-Grubbs' Sunken Garden at the Parkwood Estate. Photo Credit: Julie Nash. 


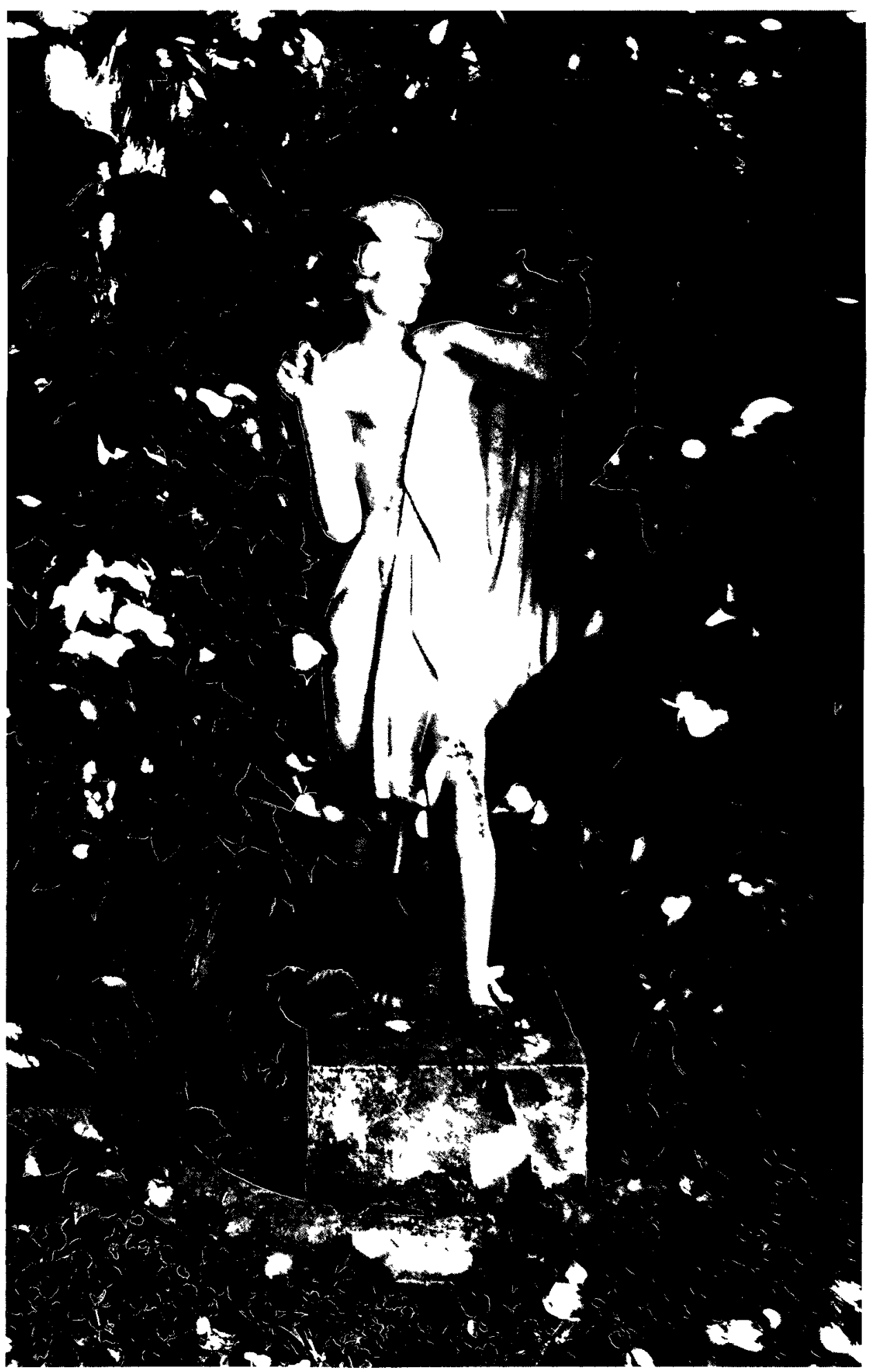

Fig. 34: Frances Loring, Girl With Squirrel (c. 1922), in situ at the Parkwood Estate and Gardens, Oshawa. Photo Credit: Julie Nash. 


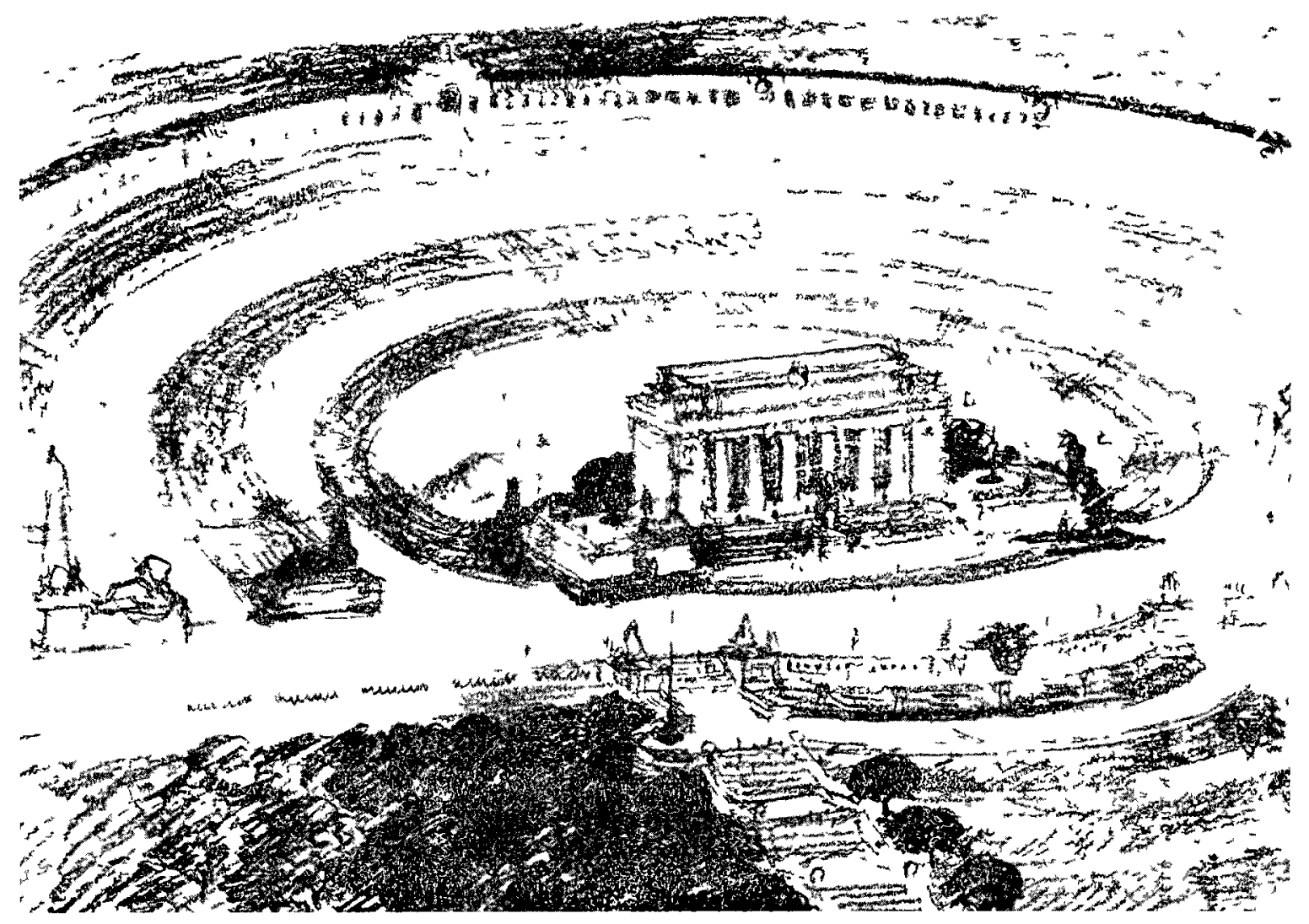

Fig. 35: Noulan Cauchon, plan for an amphitheatre in Hamilton (1917) 


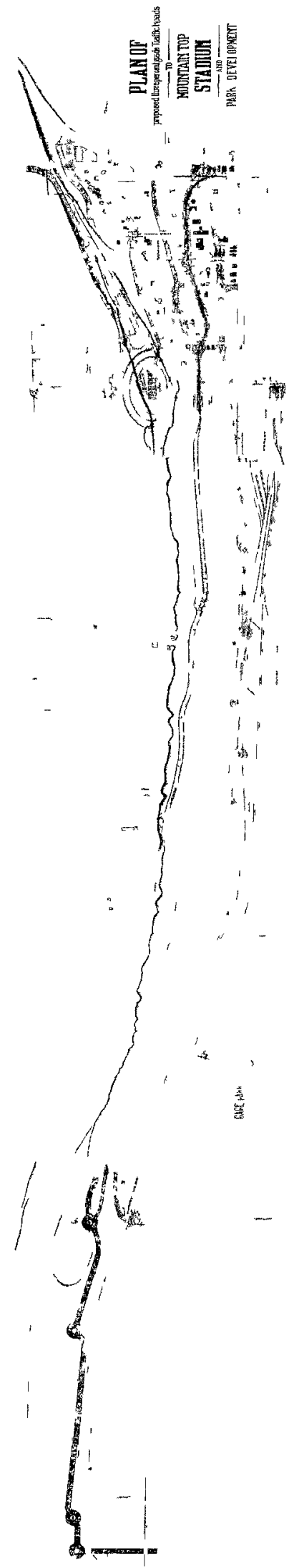

Fig. 36: Noulan Cauchon, map of streets and highways from Report on Mountain Highways of Hamilton, Ontario (1919). 


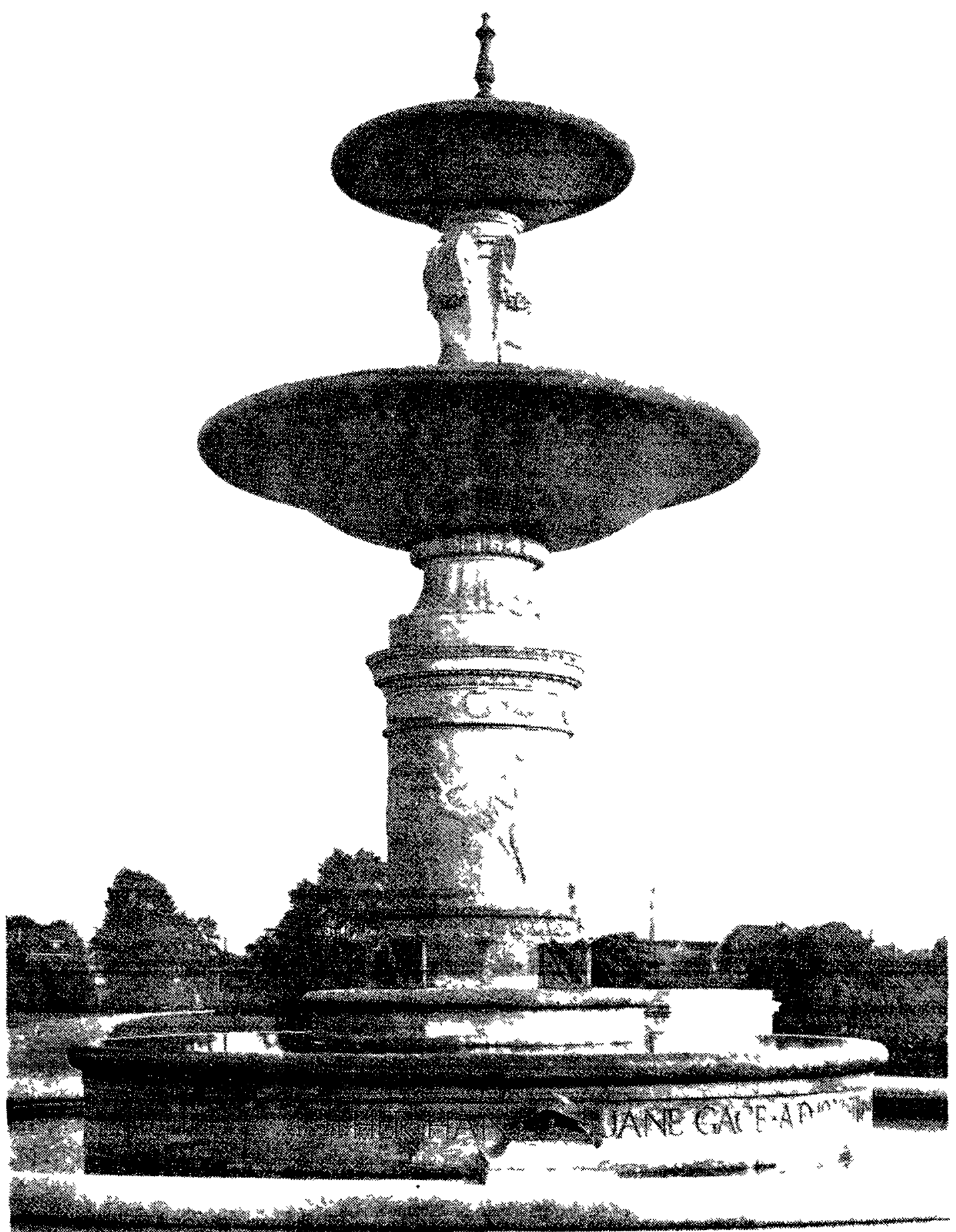

Fig. 37: John Lyle, Gage Park Fountain, Hamilton (c 1927). 


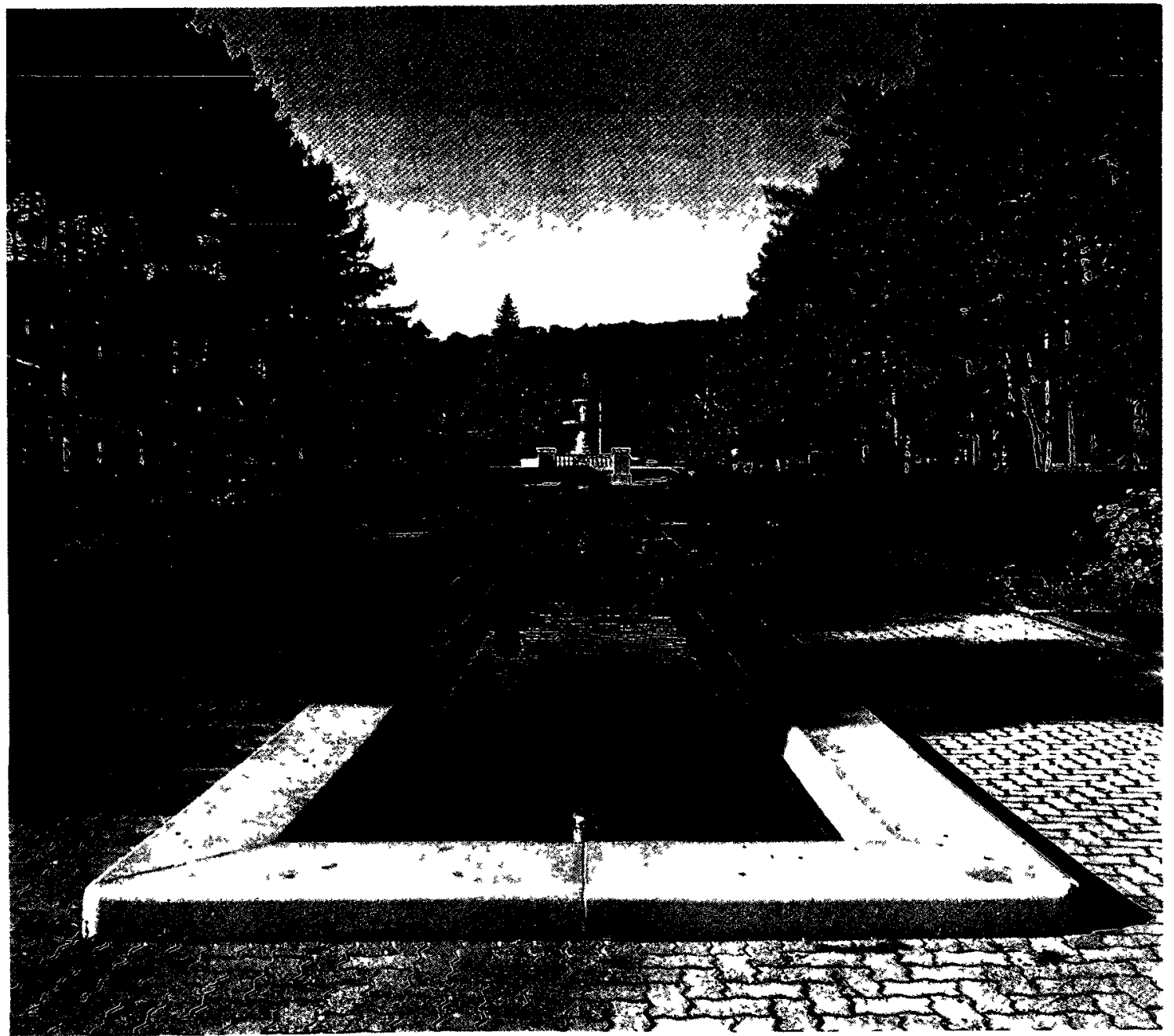

Fig. 38: Gage Park Fountain set against mountain scenery. Photo Credit: Glenn McArthur, A Progressive Traditionalist: John M. Lyle, Architect (Toronto: Coach House Books, 2009). 


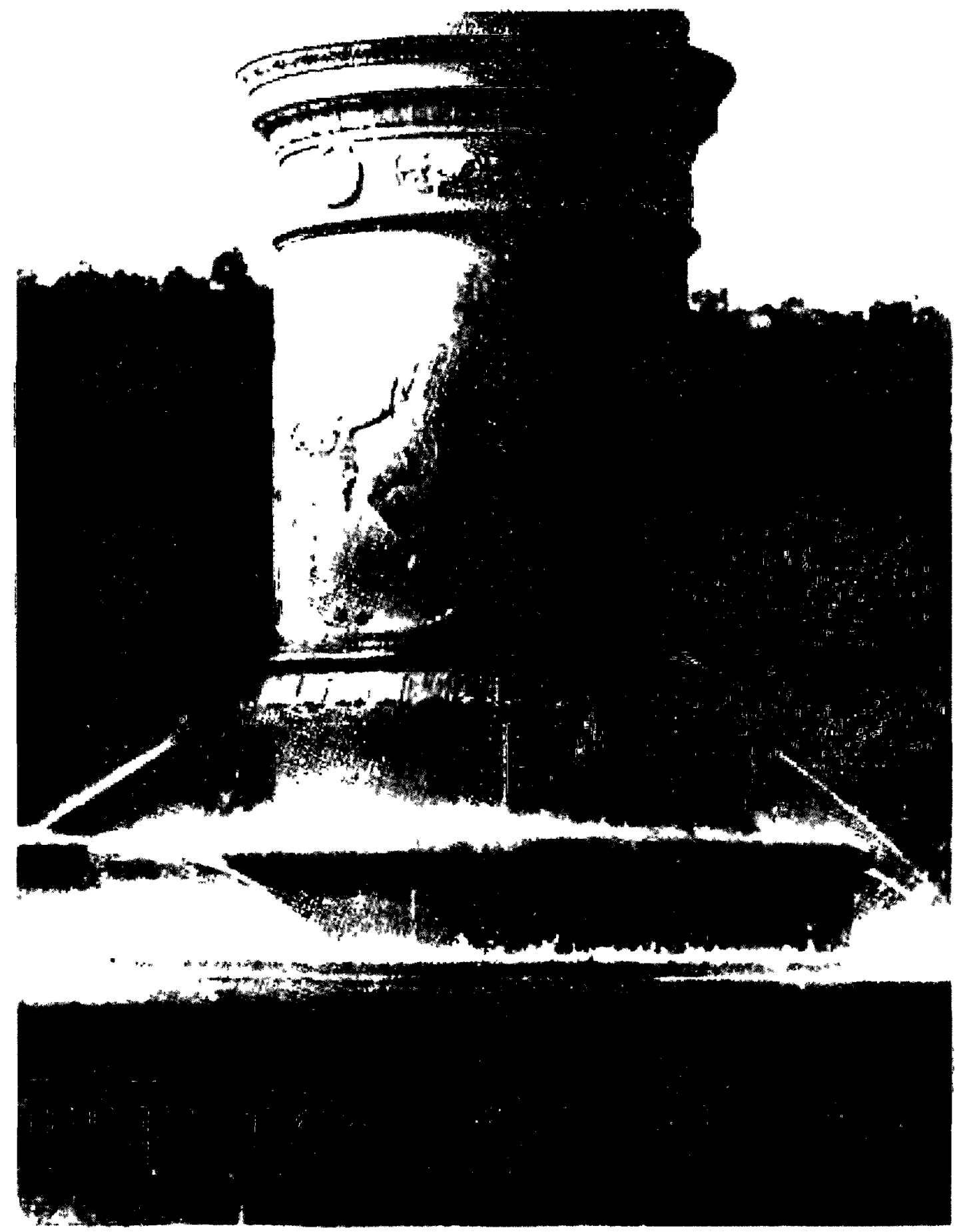

Fig. 39: Florence Wyle, Relief of Dancing Children (c. 1927). Photo Credit: Glenn McArthur, A Progressive Traditionalist: John M. Lyle, Architect (Toronto: Coach House Books, 2009). 


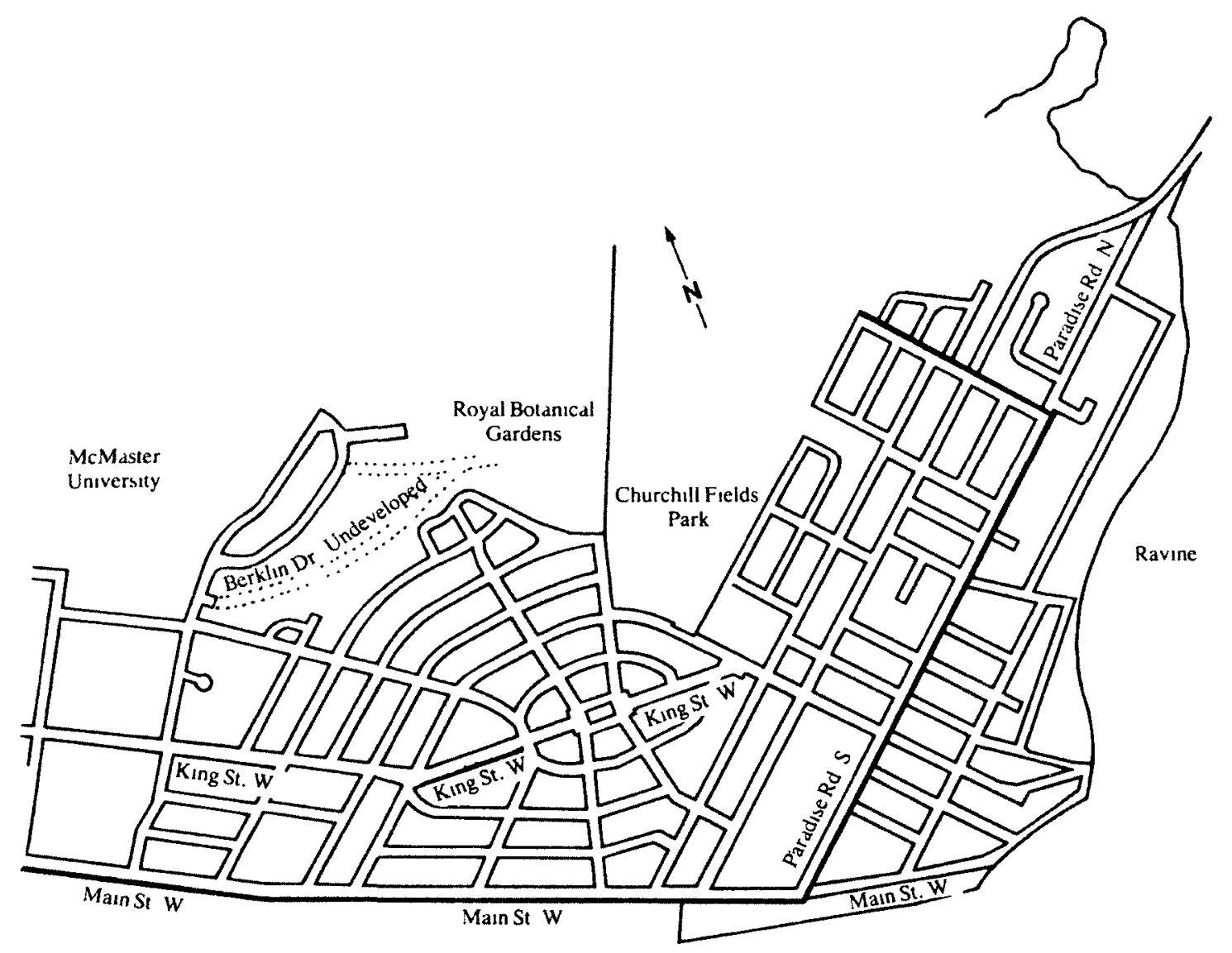

Fig. 40: Map of Hamilton showing McMaster, Westdale (at centre) and the Royal Botanical Gardens in 1931. 


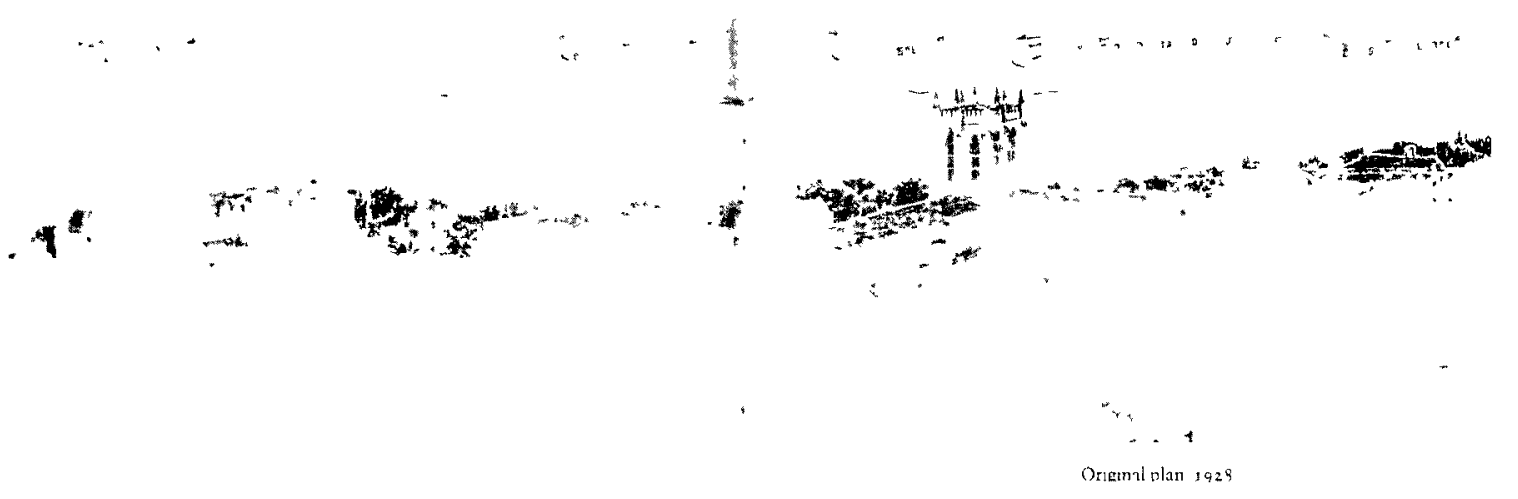

Fig. 41: Original design for McMaster University, Hamilton (1928). Photo Credit: Charles M. Johnston, McMaster University, the Early Years in Hamilton, 1930-1957 (Toronto: University of Toronto Press, 1981). 


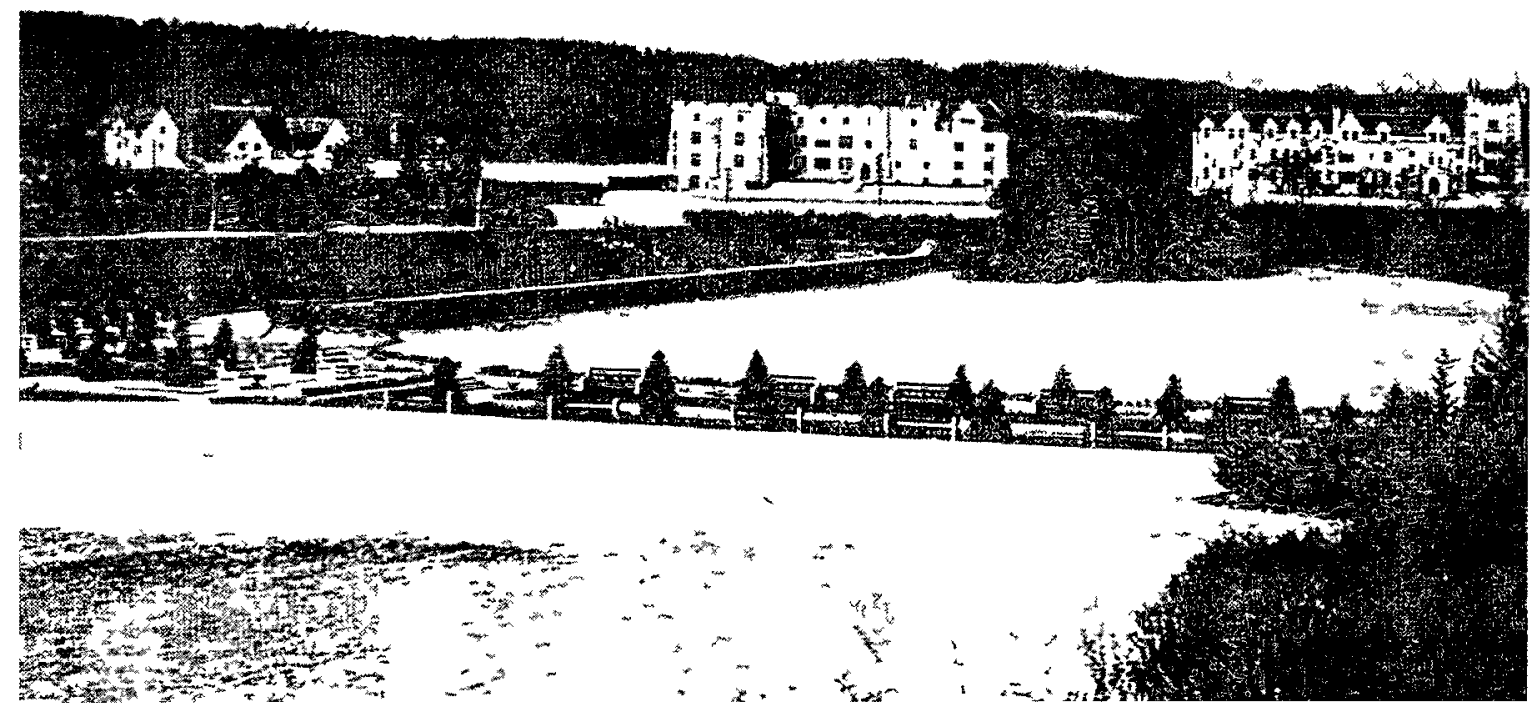

Fig. 42: The onginal Hamilton campus of McMaster University with the DuningtonGrubb Sunken Garden in the foreground (c 1930) Photo Credit Hamilton Public Library, Special Collections 


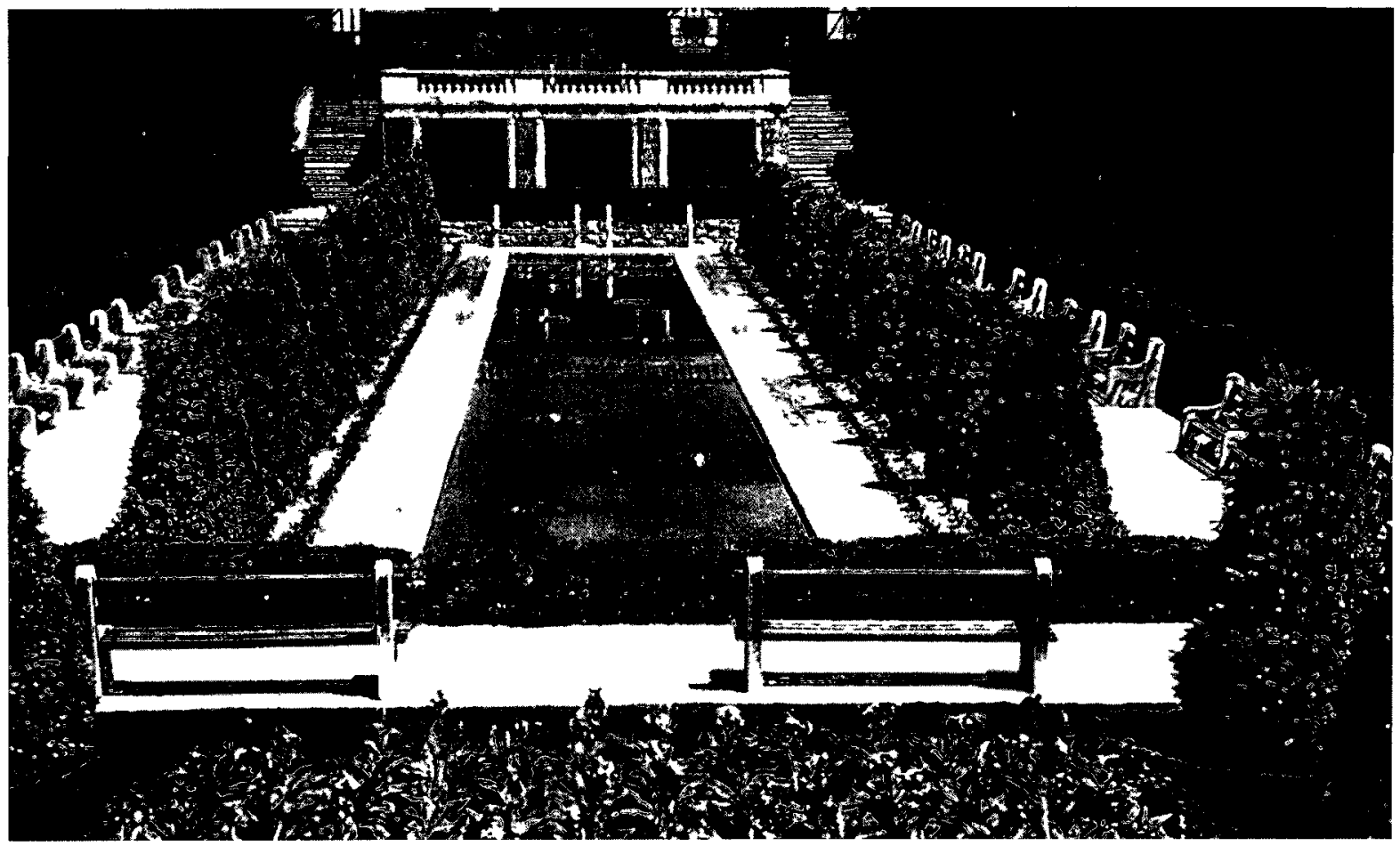

Fig. 43: Lorrie and Howard Dunington-Grubb, Sunken Garden at McMaster University (1929). Photo Credit: Mary J. Anderson, Tragedy and Triumph: Ruby and Thomas Baker McQuesten (Dundas: Tierceron Press, 2011). 


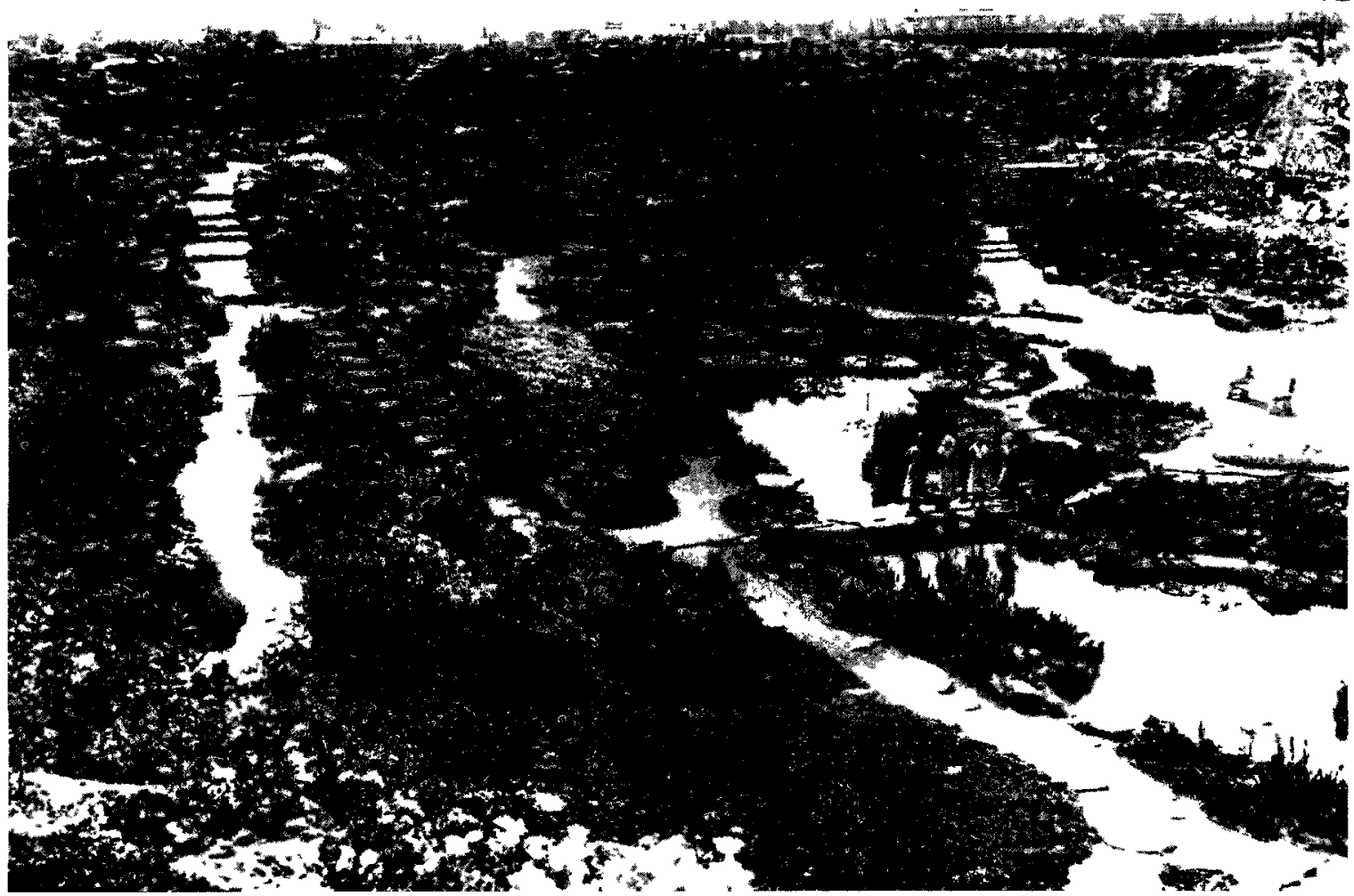

Fig. 44: Nearly completed Rock Garden at Royal Botanical Gardens, Hamilton (1931). Photo Credit: Royal Botanical Gardens. 


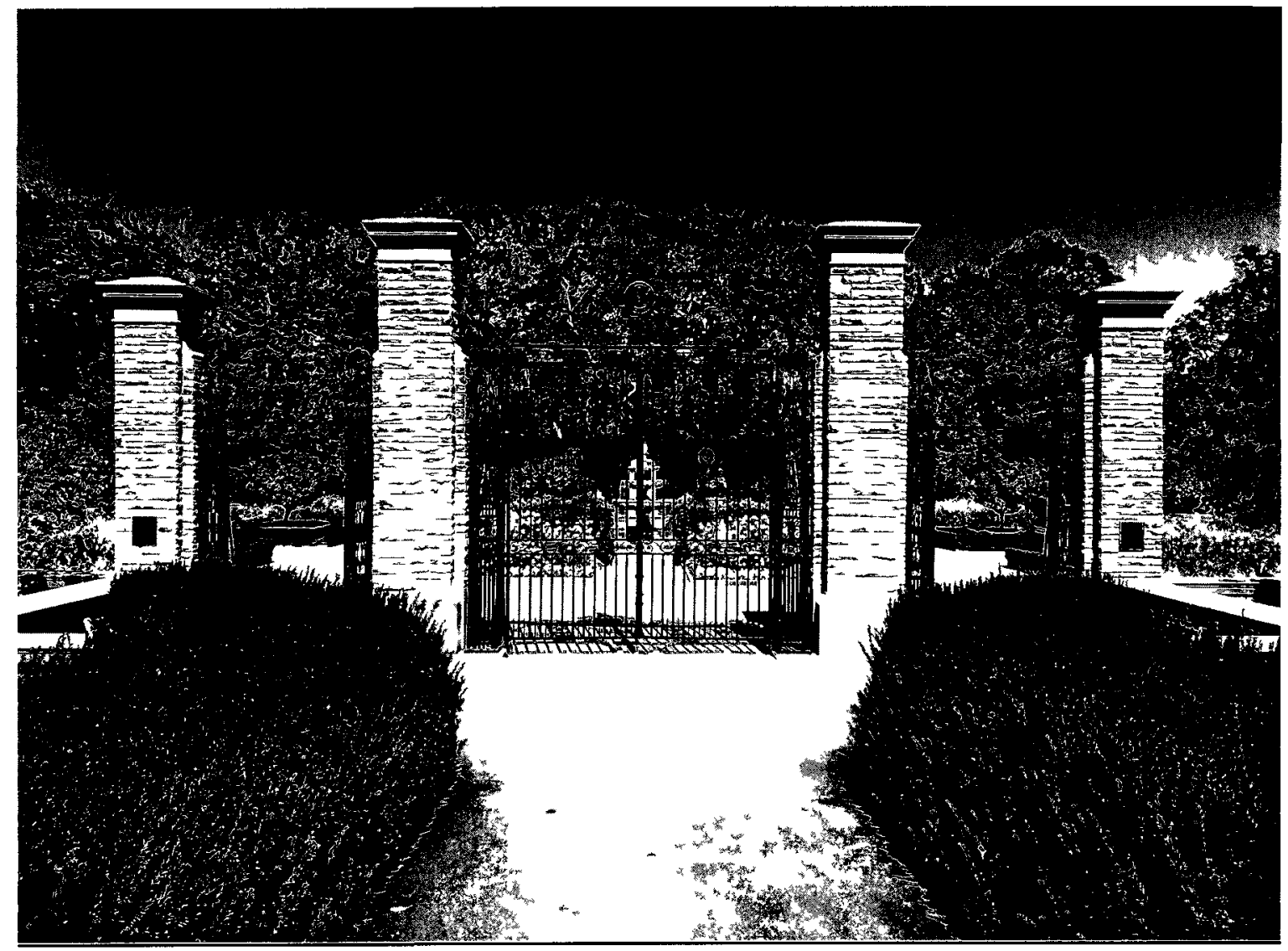

Fig. 45: Fred Flatman, Iron Gates for Hendrie Park, Royal Botanical Gardens, Hamılton (wrought in 1931, installed in 1953) Photo Credit Julıe Nash 

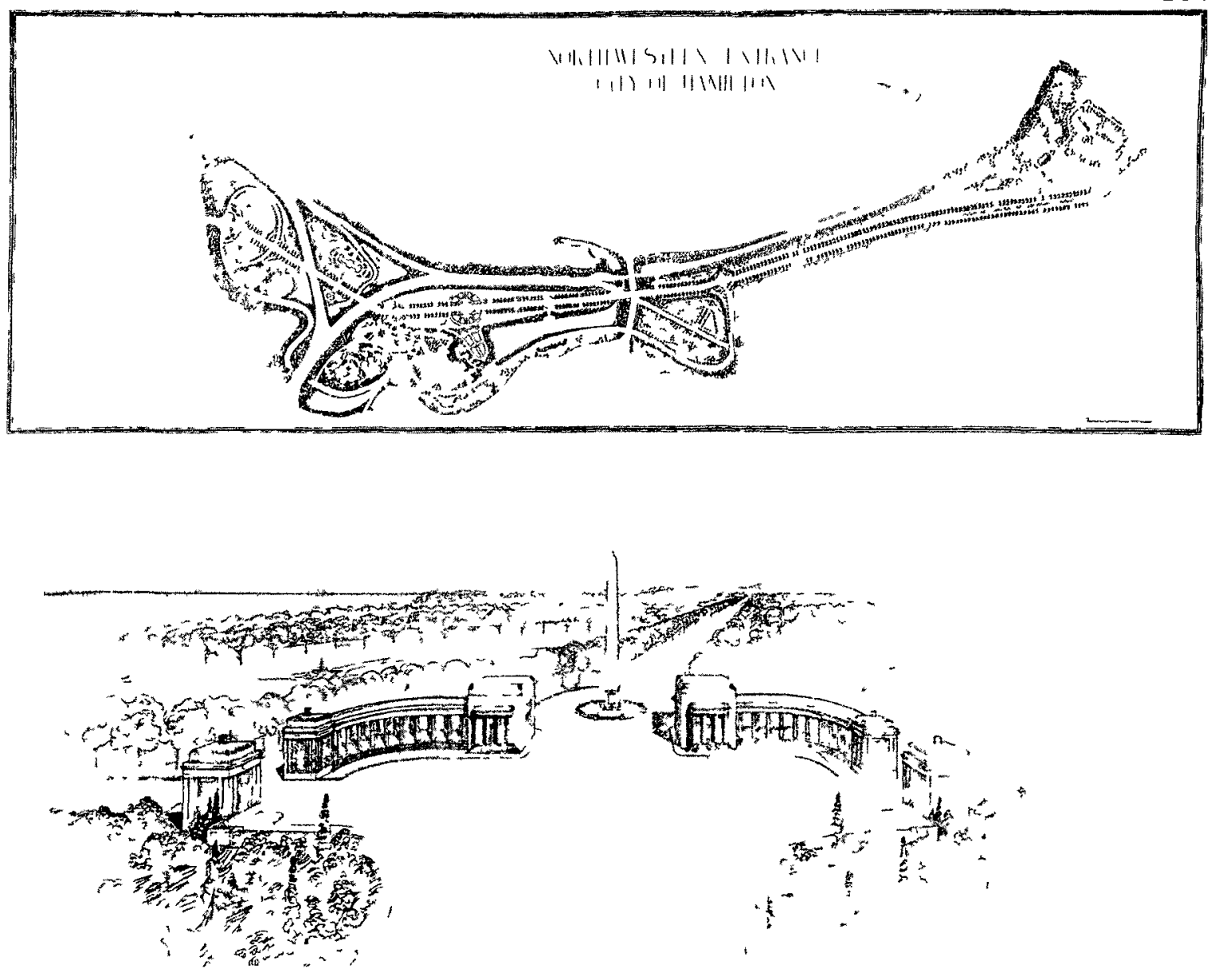

Fig. 46: Wilson, Bunnell and Borgstrom, winning design for the northwestern entrance competition (c 1930) Photo Credit Eric Arthur, "Awards in the Competition for a NorthWestern Entrance to the City of Hamilton," JRAIC 5, no. 4 (April 1928). 

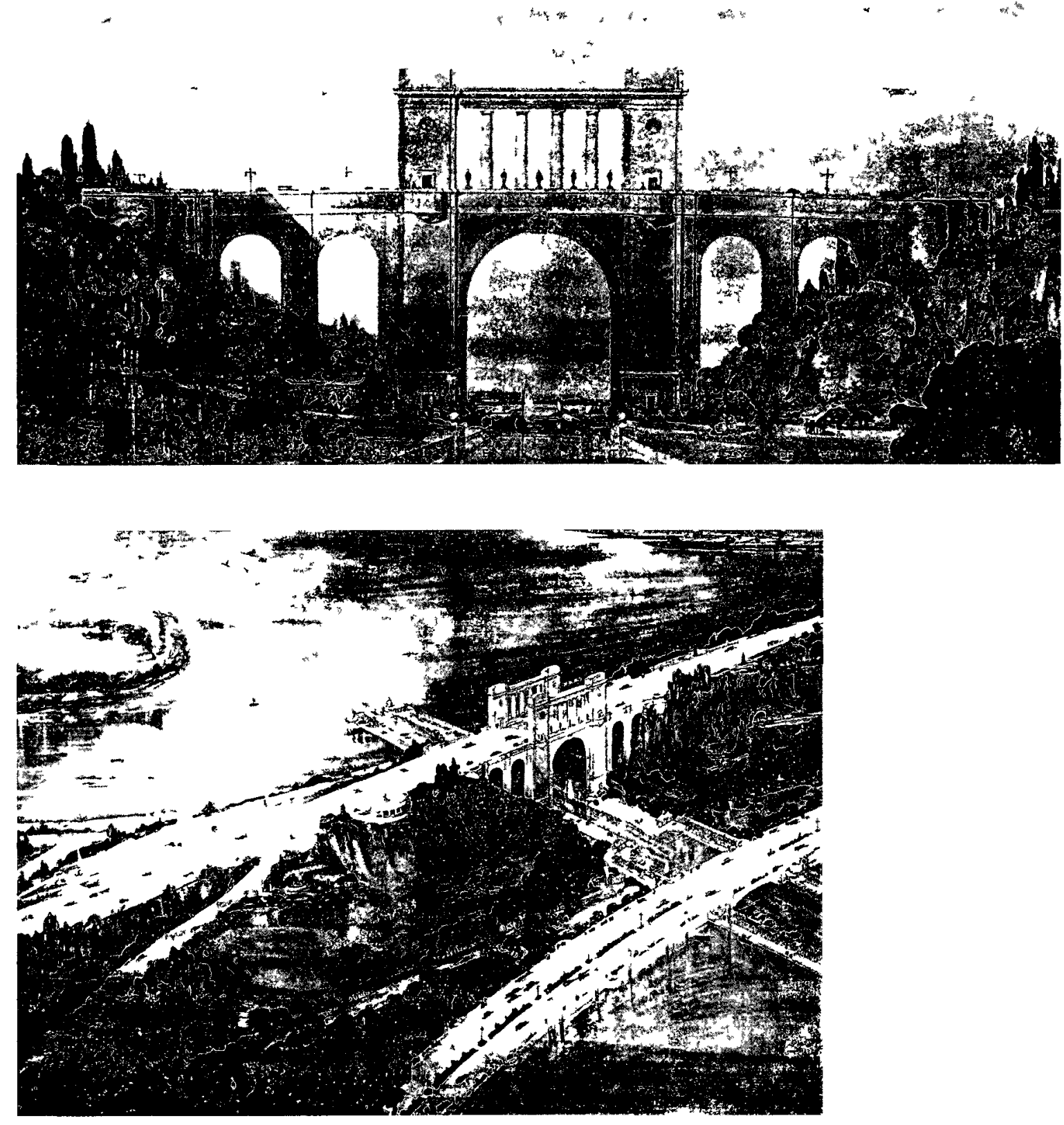

Fig. 47: John Lyle, third place design for the northwestern entrance competition including design for the new High-Level Bridge (c.1930) Photo Credit Eric Arthur, "Awards in the Competition for a North-Western Entrance to the City of Hamilton," JRAIC 5, no. 4 (April 1928). 


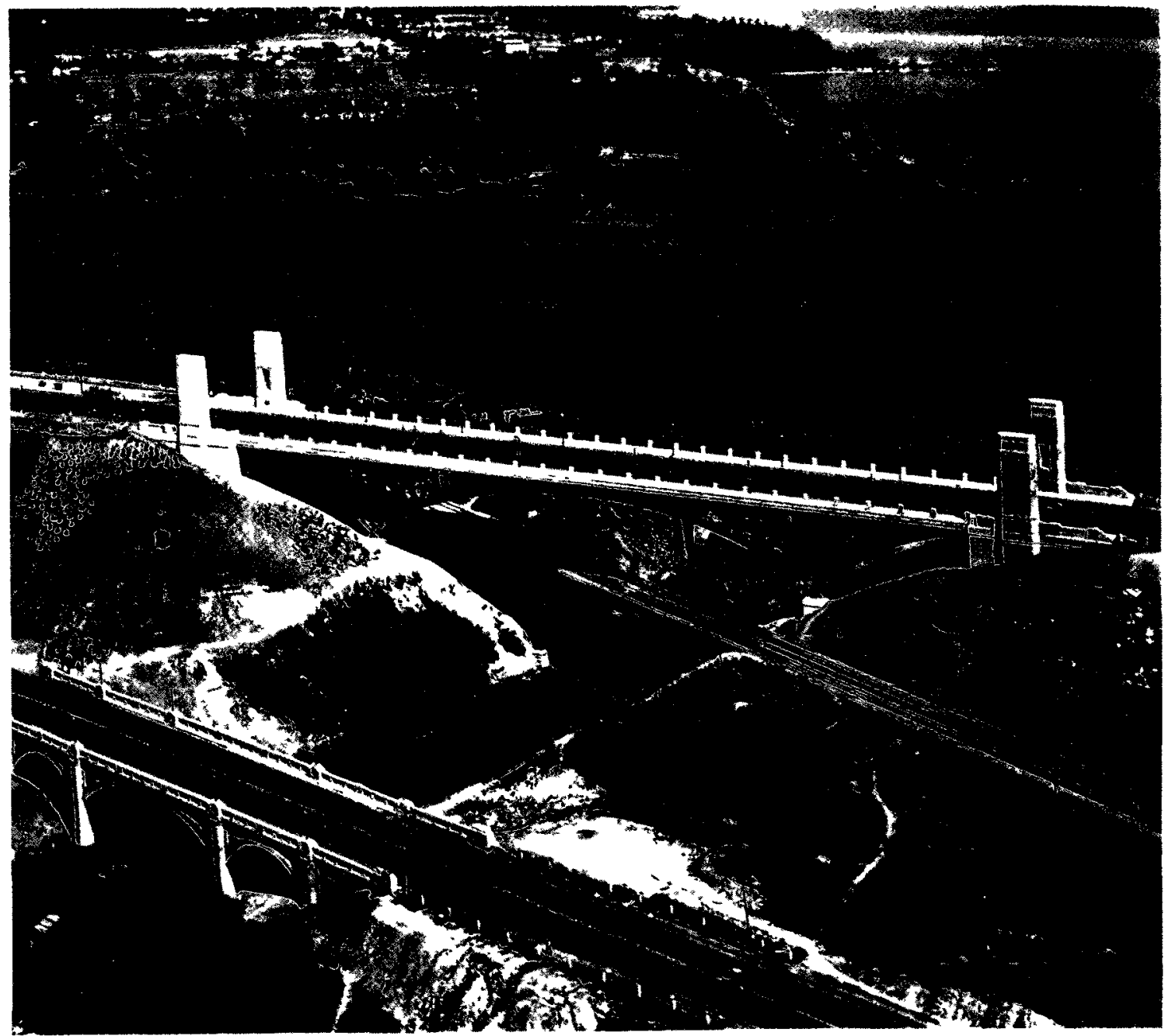

Fig. 48: John Lyle, Hamilton High-Level Bridge crossing the Desjardins Canal (c. 1932). Photo Credit: Glenn McArthur, A Progressive Traditionalist: John M. Lyle, Architect (Toronto: Coach House Books, 2009). 


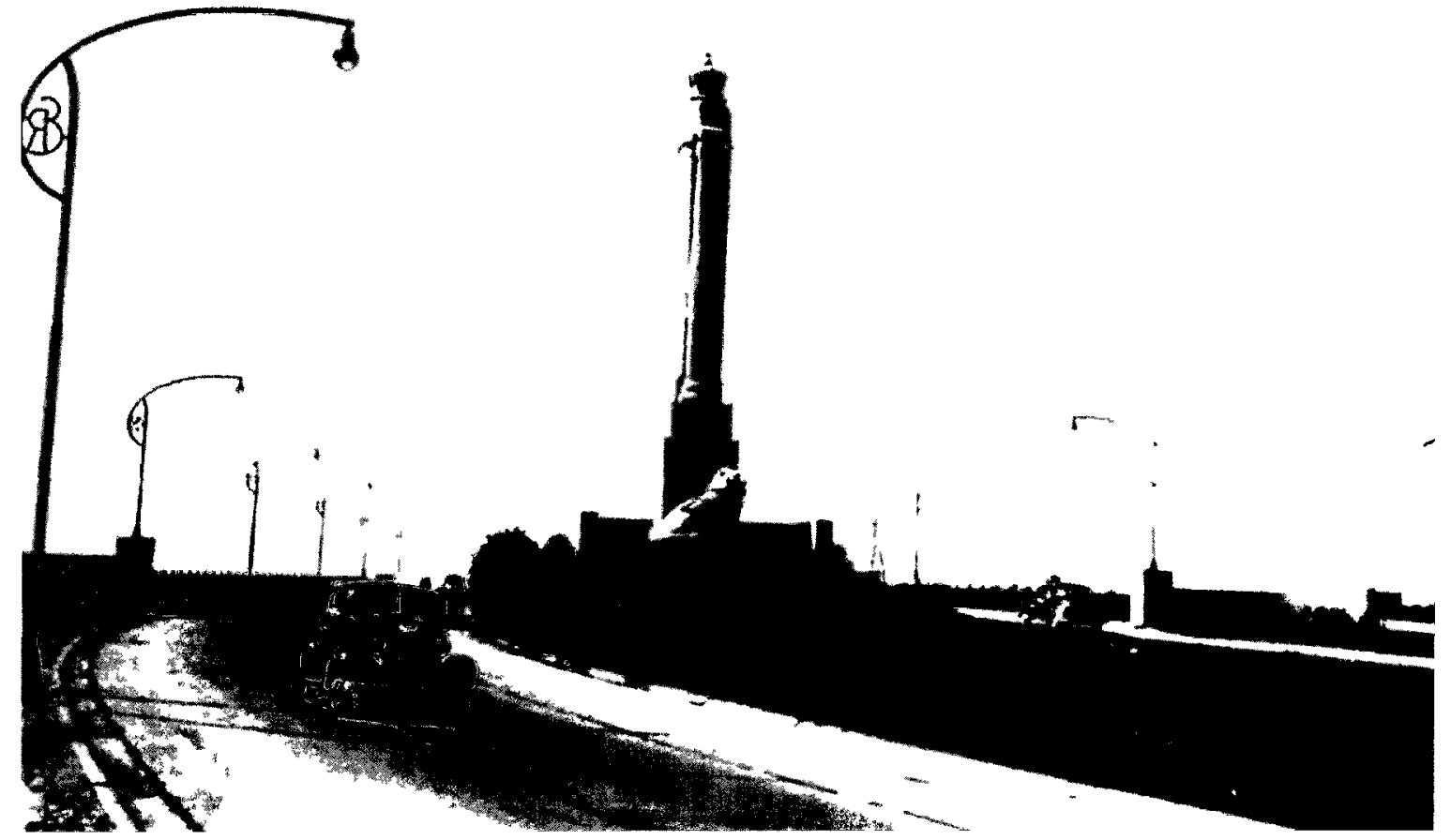

Fig. 49: Toronto Entrance to the Queen Elizabeth Way including stylized 'ER' lamp standards and the Lion Monument (c 1940). Photo Credit: Christine Boyanoski, Loring and Wyle, Sculptors' Legacy (Toronto: Art Gallery of Ontario, 1987). 


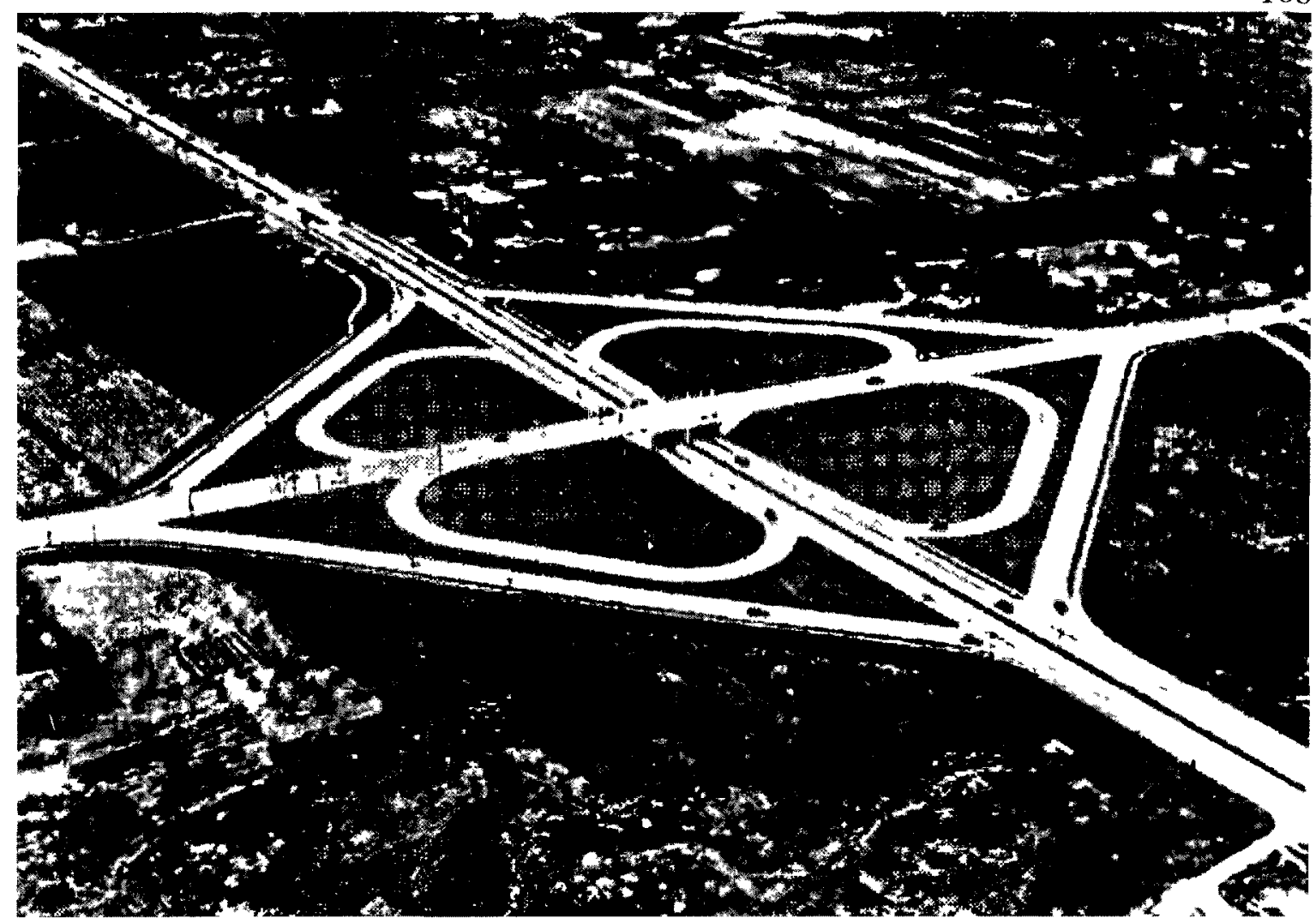

Fig. 50: Cloverleaf interchange on the Queen Elizabeth Way (c.1940). Photo Credit: Robert M. Stamp, QEW: Canada's First Superhighway (Erin: Boston Mills Press, 1987). 


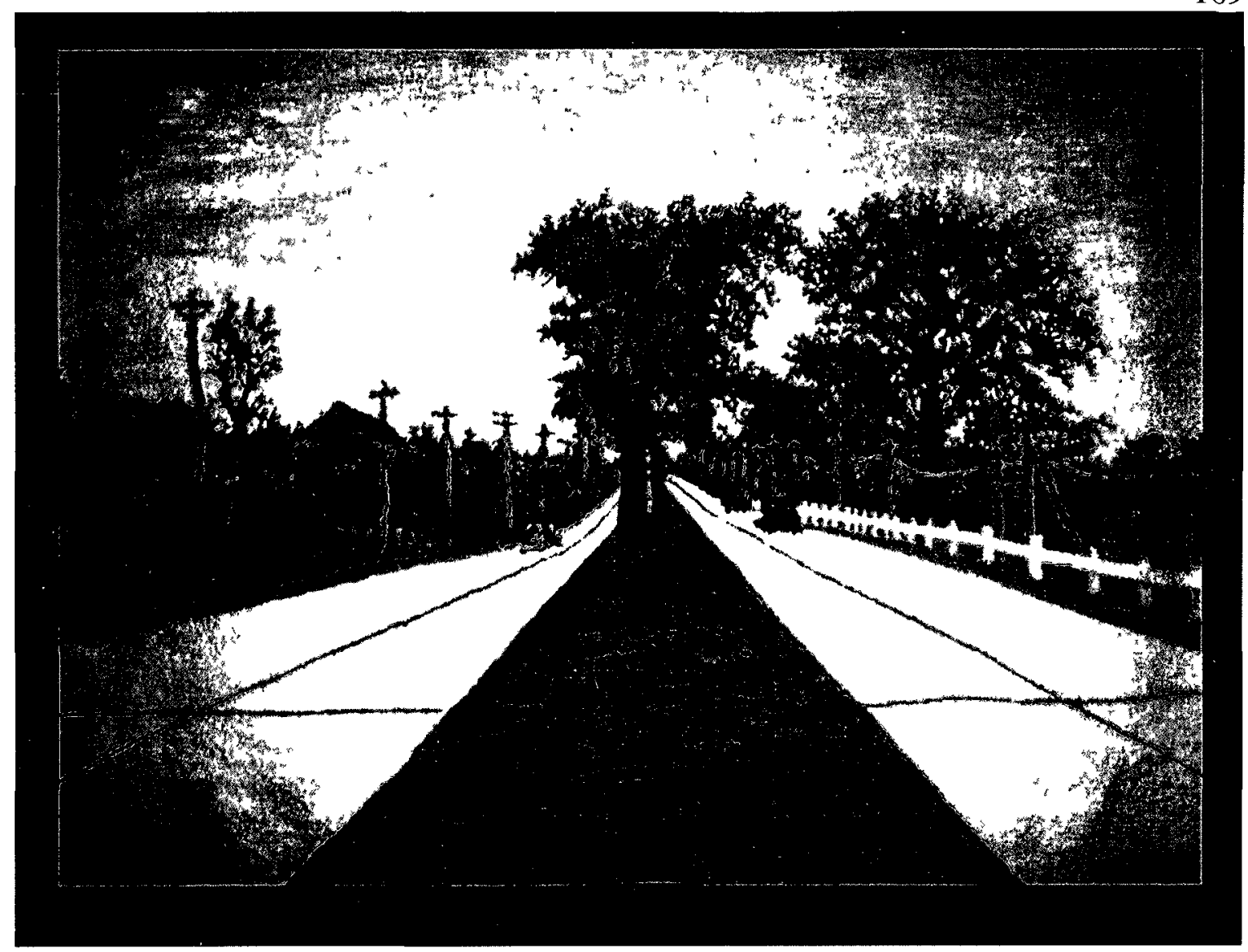

Fig. 51: Tapestry showing the original appearance of the Queen Elizabeth Way upon completion in 1940 (according to the vision of Thomas McQuesten). Photo Credit: Whitehern Historic House and Garden. 


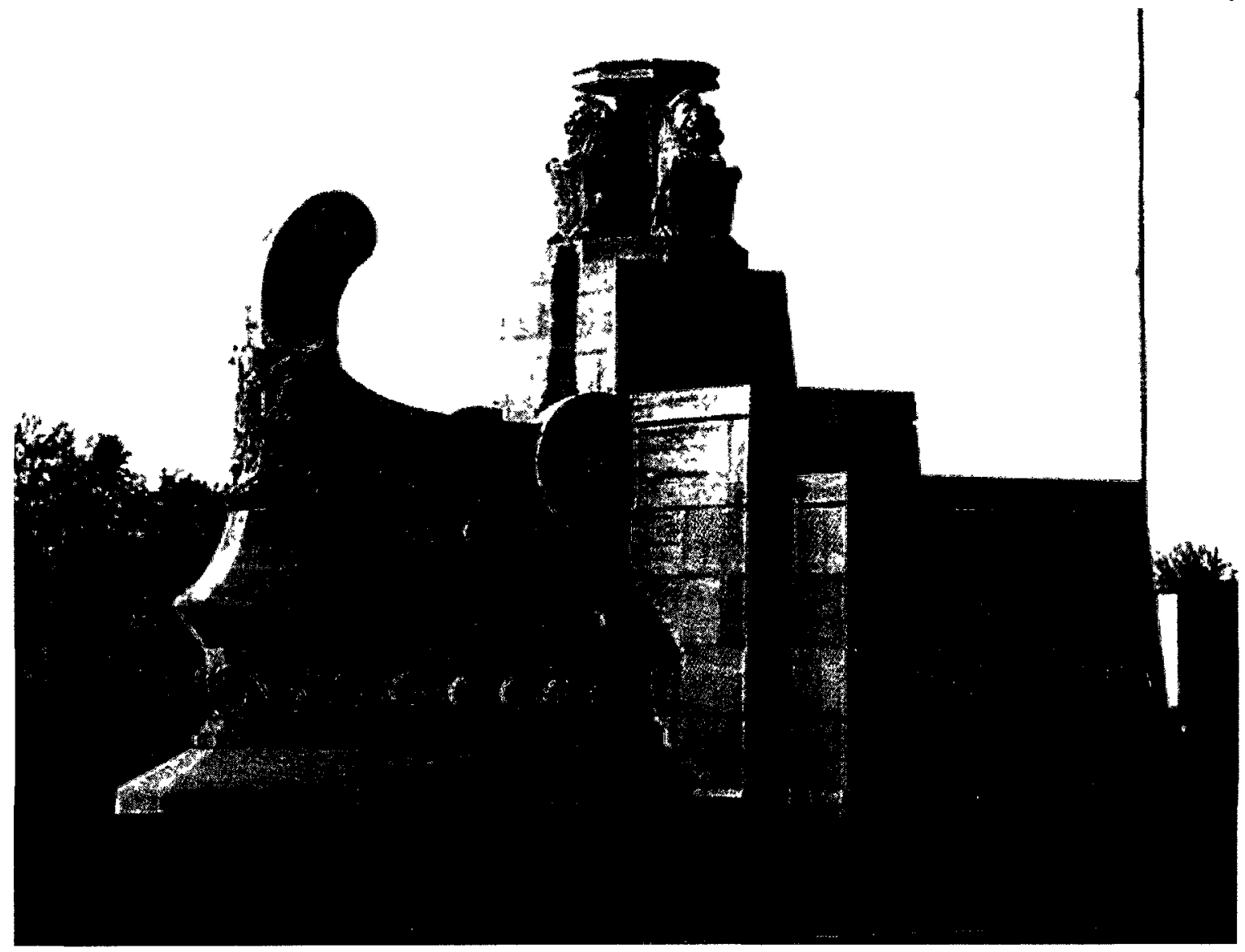

Fig. 52: William Lyon Somerville, Henley Bridge ship prow at St. Catherines (1939). Photo Credit: Mary J. Anderson, Tragedy and Triumph: Ruby and Thomas Baker McQuesten (Dundas: Tierceron Press, 2011). 


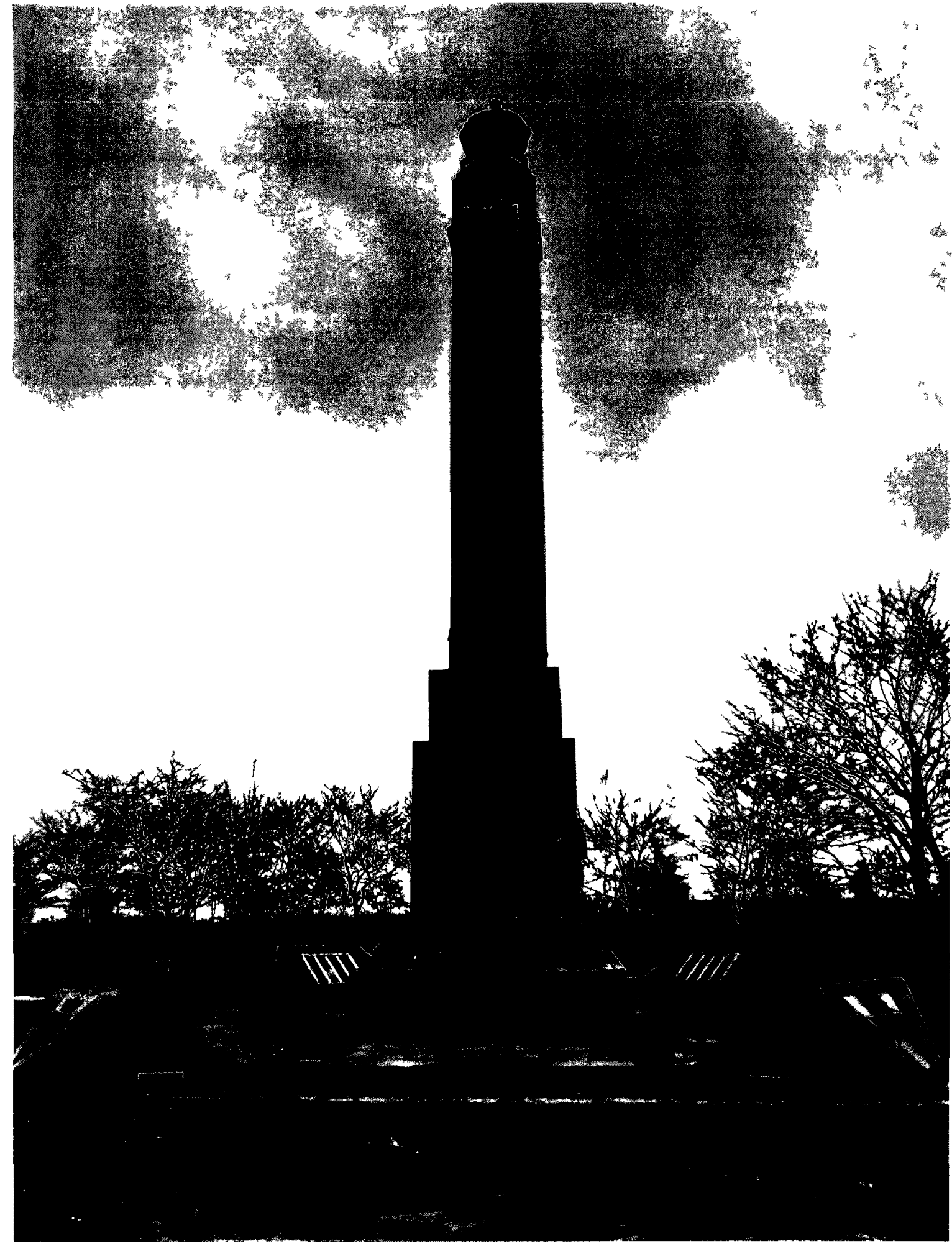

Fig. 53: William Lyon Somerville, the Lion Monument in Sir Casımır Gzowskı Park in Toronto (where it was relocated in 1975 when the Queen Elizabeth Way was expanded) Photo Credit Julie Nash 


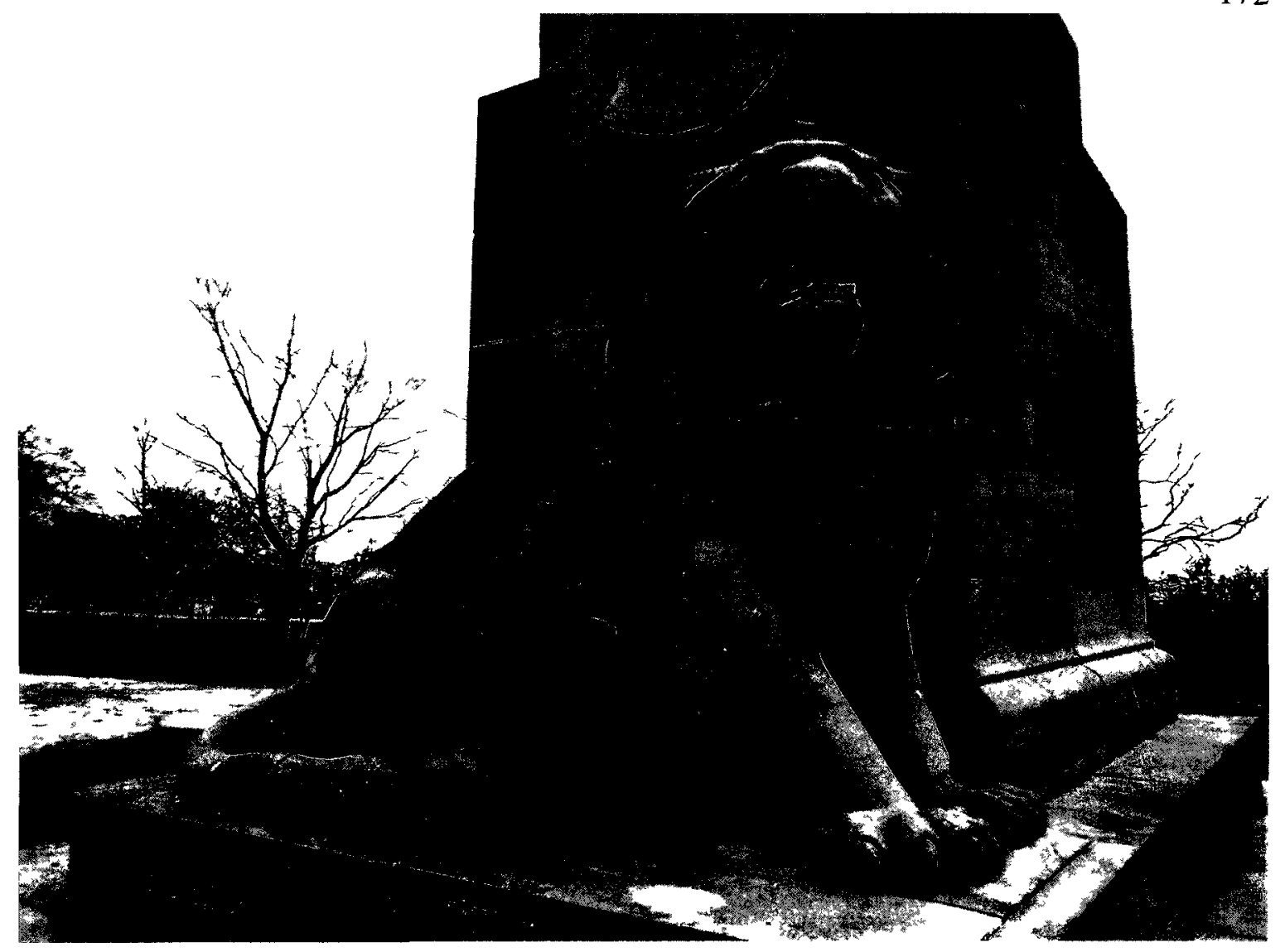

Fig. 54: Frances Loring, Imperial Lion from the Lion Monument (c. 1940). Photo Credit: Julie Nash. 
Hamilton Shows Toronto How

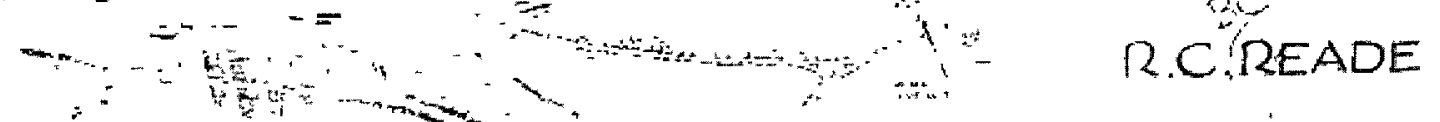
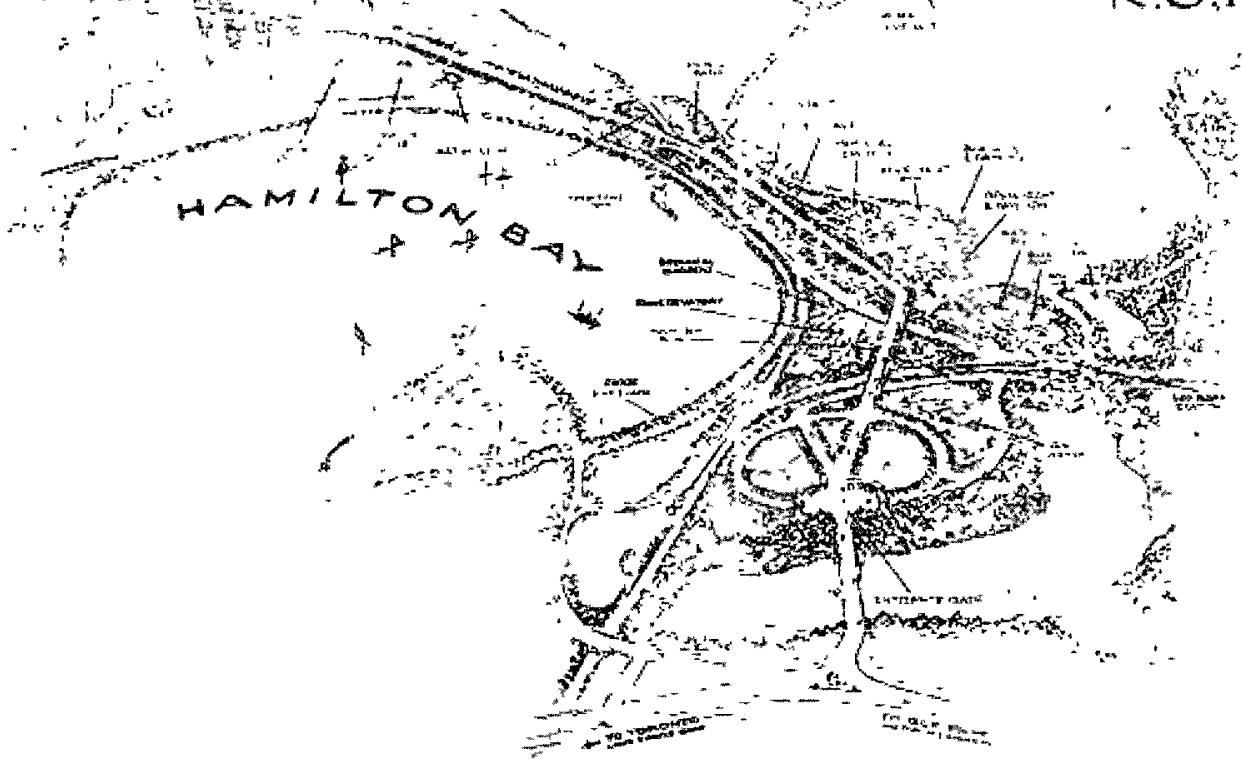

Fig. 55: R.C. Reade, "Hamilton Shows Toronto How" (1929), with diagram of Hamilton's improvements to the northwestern entrance. 


\section{Bibliography}

\section{Primary Sources}

This thesis utilizes various primary sources including conference proceedings, architectural drawings, and historical writings that were mostly gathered through McMaster University in Hamilton. McMaster University's interlibrary loan department also yielded all seven catalogues of the Biennial Exhibitions of Architecture and the Allied Arts. The remaining archival materials were accessed through the Special Collections department of the Hamilton Public Library (HPL). This archive yielded two of Noulan Cauchon's reports on Hamilton, including Reconnaissance Report on Development of Hamilton, Ontario (1917) and Report on Mountain Highways of Hamilton, Ontario (1919). Furthermore, this thesis accessed a number of subject-specific HPL scrapbooks, including the Hamilton City Planning scrapbook, Vol. 1, c. 1915- 1967 (R 711. 409713 H18 ha v.1); the Gage Park Scrapbook, Vol. 1, 1917-1983 (R712. 50971352 GAG v.1); the High Level Bridge Scrapbook, Vol. 1, 1929- (R 624.20971352 HIG v.1); the Royal Botanical Gardens Scrapbook, Vol.1, 1877-1957 (R712.56 H182 v.1); and the McMaster University Scrapbook, Vol. 1, 1909-1949 (R378. 71352 MCM v.1). Newspaper articles outside of these scrapbooks, particularly those from the Hamilton Herald, were also accessed through HPL.

\section{Secondary Sources}

“Garden at 'Parkwood' for Colonel R.S. McLaughlin, Oshawa, Ontario: John M. Lyle, Architect." JRAIC 16 (Mar. 1939): 63.

"How Hamilton Might Become City Beautiful." Hamilton Herald, August 4, 1917.

"Notes from the Architects' Show." Canadian Homes and Gardens 10 no. 9 (Mar. 1933): $20-21,54$.

“Railway Proposals Fully Explained." Hamilton Herald, August 17, 1917.

"The Toronto Guild of Civic Art." CAB 11 no. 3 (Mar. 1898): 51.

Ackerman, Frederick. "The Architectural Side of City Planning." In Proceedings of the Seventh National Conference on City Planning, Detroit, June 7-9, 1915. 107-120. Cambridge: The University Press, 1915.

Adams, Thomas. Outline of Town and City Planning, A Review of Past Efforts and Modern Aims. New York: Russell Sage Foundation, 1936.

" "The Beginnings of Town Planning in Canada." In Proceedings of the Eight National Conference on City Planning, Cleveland, June 5-7, 1916. 222-241. Cambridge: The University Press, 1916. 
Anderson, Mary J. Tragedy and Triumph: Ruby and Thomas Baker McQuesten. Dundas: Tierceron Press, 2011.

Arthur, Eric. "Toronto Chapter Architectural Exhibition." JRAIC 6 no. 3 (March 1929): 93-109.

----. "Awards in the Competition for a North-Western Entrance to the City of Hamilton." JRAIC 5, no. 4 (April 1928): 131-145.

Beatty, Stephanie and Susan Gale Hall. Parkwood. Erin: Boston Mills Press, 1999.

Best, John C. Thomas Baker McQuesten: Public Works, Politics and Imagination. Hamilton: Corinth Press, 1991.

Boddy, Trevor. "Regionalism, Nationalism, and Modernism: The Ideology of Decoration in the Work of John M. Lyle." Trace: A Canadian Review of Architecture 1 (Jan. 1981): 8-15.

Bohl, Charles C. "Civic Art Then and Now: The Culture of Good Place-making." In Sitte, Hegemann and the Metropolis: Modern Civic Art and International Exchanges, edited by Charles C. Bohl and Jean-François Lejeune. 1-21. London: Routlege, 2009.

Bouchier, Nancy B. and Ken Cruikshank. "The War on the Squatters, 1920-1940: Hamilton's Boathouse Community and the Re-Creation of Recreation on Burlington Bay." Labour 51 (Spring 2003): 9-46.

Boyanoski, Christine. Loring and Wyle, Sculptors' Legacy. Toronto: Art Gallery of Ontario, 1987.

-----. Sympathetic Realism: George A. Reid and the Academic Tradition. Toronto: Art Gallery of Ontario, 1986.

Burgess, Cecil Scott. "Civic Pride" In Architecture, Town Planning and Community, Selected Writings and Public Talks by Cecil Burgess, 1909-1946, edited by Donald G. Wetherel1. 117-126. Edmonton: University of Alberta Press, 2005.

Cauchon, Noulan. “Town Planning.” JRAIC 3 no. 4 (Jul.-Aug. 1926): 165-171.

----. Report on Mountain Highways of Hamilton, Ontario (1919). HPL.

----- Reconnaissance Report on Development of Hamilton, Ontario (1917). HPL. 
Coutu, Joan. "A Drive through Canadian History: People, Cars and Public Art at Niagara Falls in the 1930s." In Public Art in Canada: Critical Perspectives, edited by Annie Gérin and James S. McLean. 45-64. Toronto: University of Toronto Press, 2009.

-----. "Vehicles of Nationalism: Defining Canada in the 1930s." Journal of Canadian Studies 37, no. 1 (Spring 2002): 180-203.

----- "Design and Patronage: The Architecture of the Niagara Parks 1935-1941." M.A. Thesis, Queen's University, 1989.

Dawson, C.A. "The City as an Organism." In Saving the Canadian City: the First Phase 1880-1920, An Anthology of Early Articles on Urban Reform, edited by Paul Rutherford. 275-282. Toronto: University of Toronto Press, 1974.

Dickman, Chris. GA. Reid, Toward a Union of the Arts. Durham: Durham Art Gallery, 1985.

Dunington-Grubb, Howard B. "The Country Estate." Canadian Homes and Gardens (Nov. 1933): 24-25, 54.

Dunington-Grubb, Lorrie Alfreda. "Sculpture as a Garden Decoration." Canadian Homes and Garden 4 no. 3 (Mar. 1927):17-19, 48, 52.

Eadie, Arthur. "Whither Are We Bound?" JRAIC 10 no. 3 (Mar. 1933): 46-54.

Fisher, Irving D. Frederick Law Olmsted and the City Planning Movement in the United States. Ann Arbor: UMI Research Press, 1986.

Ford, George. "The City Scientific." In Proceedings of the Fifth National Conference on City Planning, Chicago, May 5-7, 1913.31-45. Cambridge: The University Press, 1913.

Garvey, Timothy. Public Sculptor, Lorado Taft and the Beautification of Chicago. Urbana: University of Illinois Press, 1988.

Gordon, David. “'Agitating people's brains': Noulan Cauchon and the City Scientific in Canada's Capital." Planning Perspectives 23 (Jul. 2008): 349-379.

---. "A City Beautiful plan for Canada's capital: Edward Bennett and the 1915 Plan for Ottawa and Hull." Planning Perspectives 13 (1998): 275-300.

Gorrell, Donald K. The Age of Social Responsibility: The Social Gospel in the Progressive Era, 1900-1910. Macon: Mercer University Press, 1988. 
Hahn, Emanuel. “Architectural Sculpture.” JRAIC 9 no. 8 (Aug. 1932): 189-194.

----. "Sculpture in Canada." In Yearbook of the Arts in Canada, 1928-1929, edited by

Bertram Brooker. 93-97. Toronto: Macmillan Company of Canada Limited, 1929.

Hegemann, Werner and Elbert Peets. The American Vitruvius: An Architect's

Handbook of Civic Art. 1922. Reprint, edited by Alan J. Plattus. New York:

Princeton Architectural Press, 1988.

Hewitt, G. Trafford. "Canada and the United States as a Field for the Garden City Movement." In Proceedings of the Sixth National Conference on City Planning, Toronto, May 25-27, 1914 . 180-193. Cambridge: The University Press, 1914.

Hunt, Geoffrey. John M. Lyle, Toward a Canadian Architecture. Kingston: Agnes Etherington Art Centre, 1982.

Hynes, J.P. "Historic." In Report on a Comprehensive Plan for Systematic Civic Improvements in Toronto. 3-7. Toronto: Toronto Guild of Civic Art, 1909.

Jenkins, Simon. "Beauty is a Dirty Word.” The Sunday Times, March 15, 2009.

Johnston, Charles M. McMaster University, the Early Years in Hamilton, 1930-1957.

Toronto: University of Toronto Press, 1981.

Kredl, Lawrence Peter. "The Origin and Development of Mount Royal Park, Montreal, 1874-1900: Ideal vs. Reality.” M.A. Thesis, York University, 1983.

Laking, Leslie. Love, Sweat and Soil, A History of Royal Botanical Gardens from 1930 to 1981. Hamilton: Royal Botanical Gardens Auxiliary, 2006.

Langton, W.A. "A Plan for Toronto." In Report on a Comprehensive Plan for Systematic Civic Improvements in Toronto. 10-17. Toronto: Toronto Guild of Civic Art, 1909.

Link, Arthur S. and Richard McCormick. Progressivism. Arlington Heights: Harlan Davidson, Inc., 1983.

Loring, Frances. "Sculpture in the Garden." Canadian Art 1, no. 2 (Dec.- Jan. 1943-44): 64-67.

Lyle, John M. “Civic Beautification.” JRAIC 5 no. 7 (Jul. 1928): 238-240.

-.... "The Allied Arts at the Recent Toronto Chapter Exhibition." JRAIC 4 no. 5 (May 1927): 164-170.

----. "Canadian Architecture." JRAIC 4 no. 2 (Feb. 1927): 59-72. 
MacCarthy, Hamilton. "The Aesthetic Unity of the Fine Arts - Most Especially in Relation to Architecture." $C A B 8$ no. 3 (Mar. 1895): 46-47.

MacTavish, Newton. The Fine Arts in Canada. 1925. Reprint, Toronto: Coles Publishing Company, 1973.

Mavor, James. "Note on the Objects of the Toronto Guild of Civic Art and on the Exhibition of Prints of Mural Paintings." $C A B 11$ no. 5 (May 1898): 88-90.

Mawson, Thomas. Civic Art: Studies in Town Planning, Parks, Boulevards and Open Spaces. London: B.T. Batsford, 1911.

McArthur, Glenn. A Progressive Traditionalist: John M. Lyle, Architect. Toronto: Coach House Books, 2009.

McKay, Marylin J. A National Soul: Canadian Mural Painting, 1860s-1930s. Montreal: McGill-Queens University Press, 2002.

Miller, Muriel. George Reid, A Biography. 1946. Reprint, Edited by Ian R. Coutts. Toronto: Summerhill Press, 1987.

Murray, A.L. "Frederick Law Olmsted and the Design of Mount Royal Park, Montreal." Journal of the Society of Architectural Historians 26 no. 3 (Oct., 1967): 163-171.

National Gallery of Canada. "Biography: George A. Reid." Accessed Sept. 13, 2010. http:":cybermuse.gallery.ca/cybermuse/enthusiast/thirties/artis1 e.jsp?iartistid $=4583$

Ontario Association of Architects. Catalogue of the Seventh Biennial Exhibition of Architecture and the Allied Arts. Toronto: Art Gallery of Toronto, 1939.

----. Catalogue of the Sixth Biennial Exhibition of Architecture and the Allied Arts. Toronto: Art Gallery of Toronto, 1937.

---.. Catalogue of the Fifth Biennial Exhibition of Architecture and the Allied Arts. Toronto: Art Gallery of Toronto, 1935.

----. Catalogue of the Fourth Biennial Exhibition of Architecture and the Allied Arts. Toronto: Art Gallery of Toronto, 1933.

----. Catalogue of the Third Biennial Exhibition of Architecture and the Allied Arts. Toronto: Art Gallery of Toronto, 1931.

----. Catalogue of the Second Biennial Exhibition of Architecture and the Allied Arts. Toronto: Art Gallery of Toronto, 1929. 
-----. Catalogue of the First Biennial Exhibition of Architecture and the Allied Arts. Toronto: Art Gallery of Toronto, 1927.

Osbaldeston, Mark. Unbuilt Toronto: A History of the City That Might Have Been. Toronto: Dundurn Press, 2008.

Pepall, Rosalind. "The Murals by George A. Reid in the Toronto Municipal Buildings, 1897-1899." M.A. Thesis, Concordia University, 1982.

Pigott, Joseph M. "Civic Beautification.” JRAIC 9 no. 7 (Jul. 1932): 164-165.

Pollock-Ellwand, Nancy. "Rickson Outhet: Bringing the Olmsted Legacy to Canada. A Romantic View of Nature in the Metropolis and the Hinterland." Journal of Canadian Studies 44 no. 1 (Winter 2010): 137-183.

----. "The Olmsted Firm in Canada." In The Master List of Design Projects of the Olmsted Firm, edited by Lucy Lawliss, Caroline Loughlin and Lauren Meier. 15-18. Washington: National Association for Olmsted Parks, 2008.

Reade, R.C. "Hamilton Shows Toronto How." Toronto Star, Nov. 16, 1929.

Reid, Dennis. A Concise History of Canadian Painting. Toronto: Oxford University Press, 1973.

Reid, George A. "Applied Art." CAB 13 no. 3 (Mar. 1900): 55.

----. "Mural Decorations in the New Municipal Buildings, Toronto." CAB 12 no. 5 (May 1899): 98 .

--.-. "Mural Decoration." Canadian Magazine 10 no. 6 (Apr. 1898): 501-508.

----. "Mural Decoration." CAB 11 no. 1 (Jan. 1898): 12-15.

----. "Architecture from an Artist's Standpoint." CAB 4 no. 4 (Apr. 1891): 44-45.

Ridley, H.M. "Canada's Architectural Movement, 'The Diet Kitchen' School and Its Propaganda for the Art." Saturday Night (Mar. 12, 1927).

Robinson, Charles Mulford. Modern Civic Art; or, the City Made Beautiful. 1903. Reprint, New York: Arno Press, 1970.

----. The Improvement of Towns and Cities; or, the Practical Basis of Civic Aesthetics. 1901. Reprint, New York: Putnam and Sons, 1913. 
Rogers, Richard. "Beauty is Not A Dirty Word." Resurgence 207(July-Aug. 2001).

Scheper, George L. "The Reformist Vision of Frederick Law Olmsted and the Poetics of Park Design.” The New England Quarterly 62 no. 3 (Sept., 1989): 369-402.

Seline, Janice. "Frederick Law Olmsted's Mount Royal Park, Montreal: Design and Context.” M.A. Thesis, Concordia University, 1983.

Sherwood, W.A. “A National Spirit in Art.” Canadian Magazine 3 (Oct. 1894): 498-501.

Simmins, Geoffrey. "Improving the City - Thomas Mawson." In Documents in Canadian Architecture, edited by Geoffrey Simmins. 77-99. Peterborough: Broadview Press, 1992.

----. Ontario Association of Architects: A Centennial History, 1889-1989. Toronto: Ontario Association of Architects, 1989.

Somerville, W.L. "Why the Interior Decorator?” JRAIC 9 no. 6 (Jun. 1932): 138-143.

Stamp, Robert M. QEW: Canada's First Superhighway. Erin: Boston Mills Press, 1987.

Stelter, Gilbert A. "Rethinking the Significance of the City Beautiful Idea." In Urban Planning in a Changing World: The Twentieth Century Experience, edited by Robert Freestone. 98-117. London: E \& FN Spon, 2000.

Terpstra, Nicholas. "Local Politics and Local Planning: A Case Study of Hamilton, Ontario, 1915-1930." Urban History Review/Revue d'histoire urbaine 14 no. 2 (Oct. 1985): 115-128.

Thompson, P.W. "Toronto's Heritage of Ugliness." JRAIC 9 no. 9 (Sept. 1932): 212-213.

Toronto Guild of Civic Art. By-Laws of the Toronto Guild of Civic Art. Toronto: Oxford Press, 1906.

Van Nostrand, John C. "The Queen Elizabeth Way: Public Utility Versus Public Space." Urban History Review/Revue d'histoire urbaine 7, no. 2 (Oct, 1983): 1-23.

Van Nus, Walter. "The Fate of City Beautiful Thought in Canada, 1893-1930." Historical Papers/Communications historiques 10 no. 1 (1975): 191-210.

Visser'T Hooft, Willem A. The Background of the Social Gospel in America. 1928. Reprint, St. Louis: The Bethany Press, 1963.

Westfall, William. "Introduction - The Regional Patterns in Canada and Canadian Culture." In Perspectives on Regions and Regionalism in Canada, edited by William Westfall. 2- 13. Ottawa: The Association for Canadian Studies, 1983. 
White, Ronald C., and C. Howard Hopkins. The Social Gospel: Religion and Reform in Changing America. Philadelphia: Temple University Press, 1976.

Wilson, William H. The City Beautiful Movement. Baltimore: Johns Hopkins University Press, 1989.

Wood, Elizabeth Wyn. "Observations on a Decade ... 1938-1948: Ten Years of Canadian Sculpture." JRAIC 25 no. 1 (Jan. 1948): 15-19. 